ضمانات الضحية في جرائم الاتجار بالبشر

(وفقاً لبروتوكول باليرمو وبعض التشريعات العربية)

$$
\text { إعداد }
$$

د. حسن يوسف مصطفى مقابله

أستاذ القانون الجنائي المساعد

كلية الشريعة - قسم الأنظمة - جامعة القصيم

بالمملكة العربية السعودية 
- 462 - 


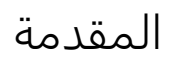

أولاً:- موضوع الدراسة:

أصبحت ظاهرة الاتجار بالبشر في الوقت الحاضر بمثابة الوجه

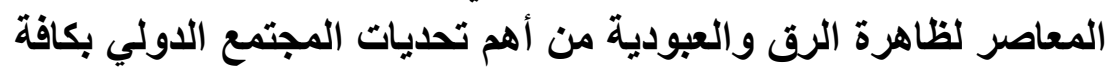

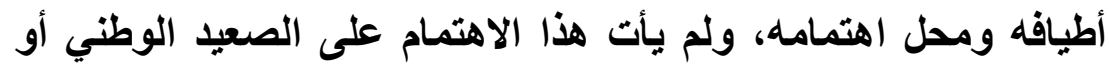

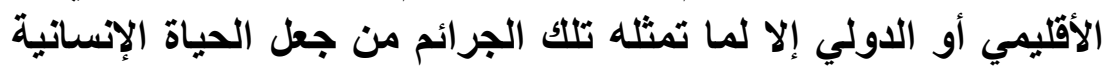

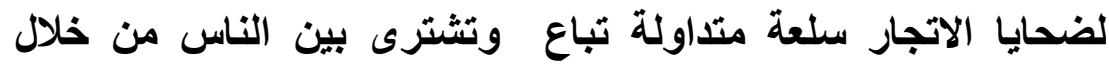

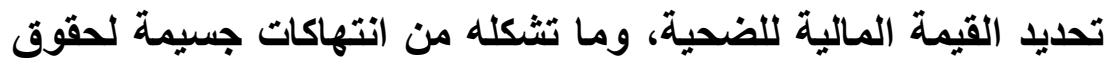

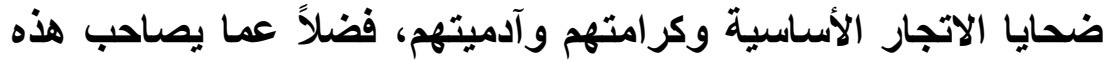

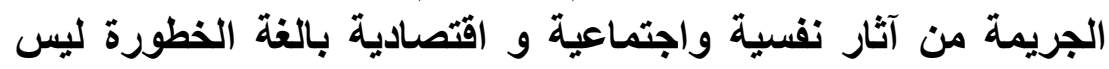

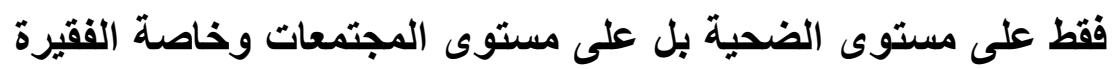
منها .

وما يزيل من خطورة تلك الجريمة الانتشار السريع لها حيث

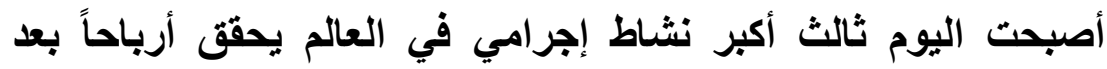

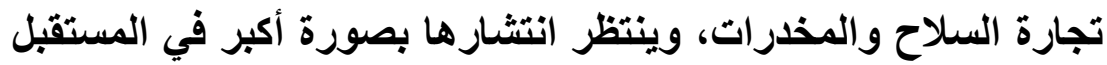

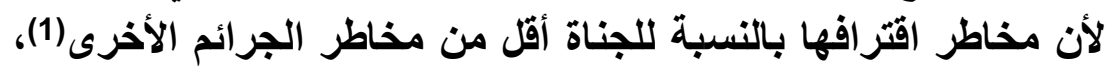

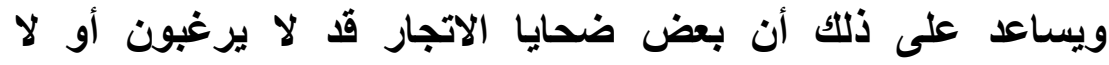
يستطيعون الإبلاغ عن هذه الجريمة لأسباب مختلفة .

ويعد الاتجار بالبشر جريمة يعاقب عليها القانون الدولي والوطني، فهي جريمة دولية عابرة للحدود الوطنية، فأثار ها لا تطال

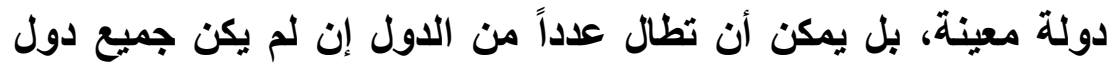

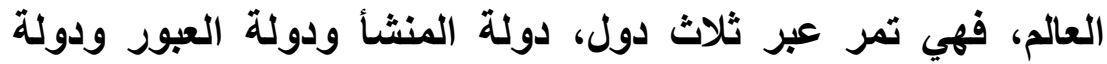
المقصد التي ينتهي إليها ضحايا الاتجار، ويقوم بها دهاب عصابات امتهنت

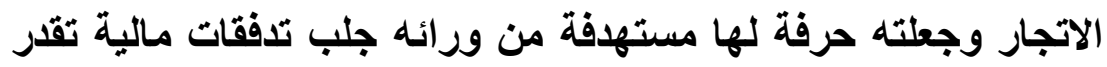


بالمليارات من الدولارات (1)، في تحد سافر للتكريم الإلهي للإنسان

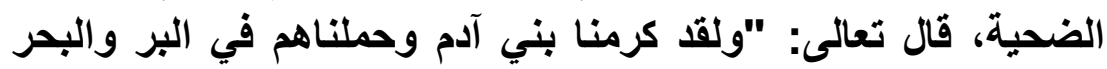

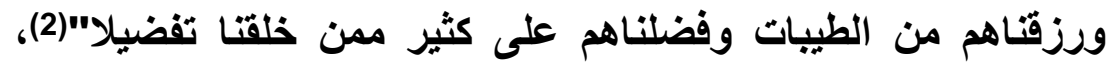

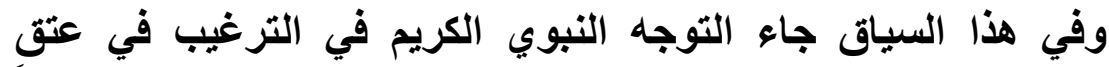

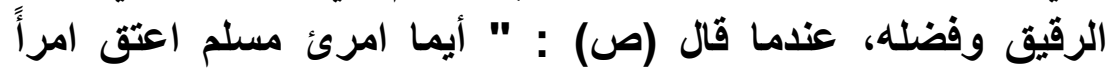
مسلماً استنقذ الله بكل عضو فيه عضواً من النار" (3).

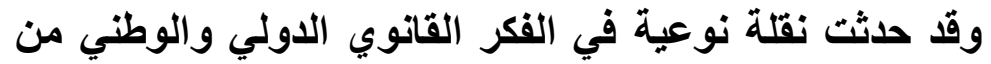

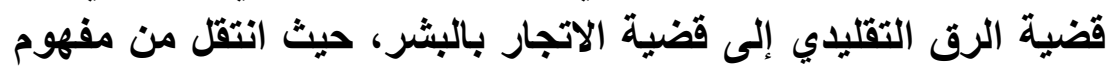

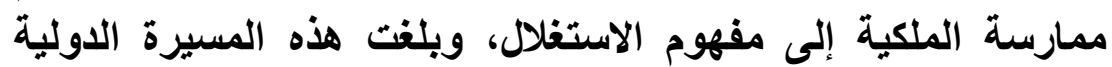

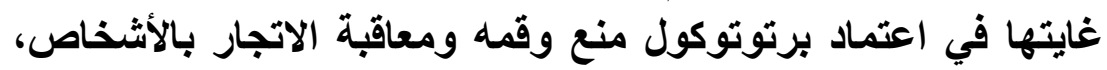

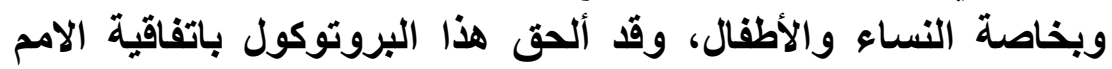

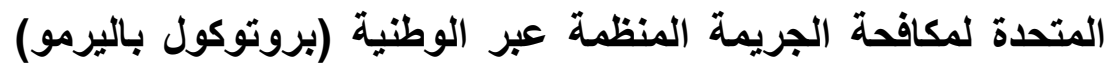

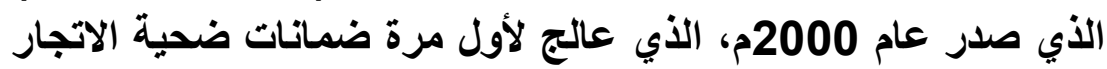

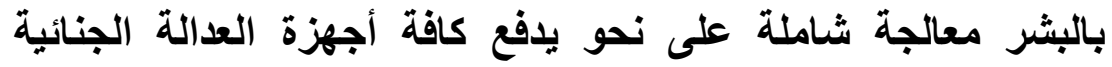

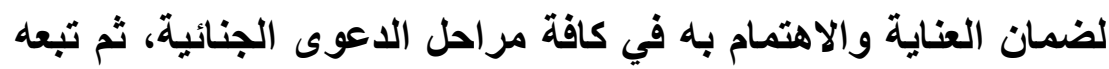

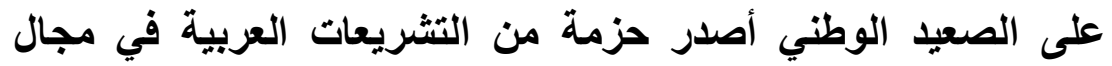

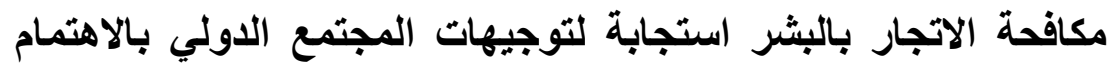

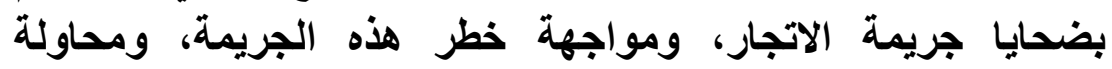
الوصول إلى وسائل قانونية تساعد في إيجاد الحلول النوائل الناجعة لحماية

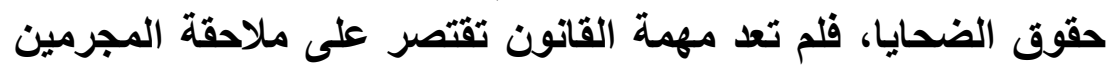

فقط.

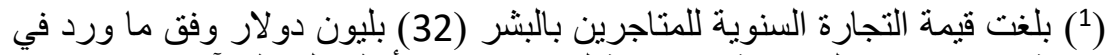

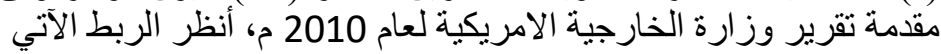
http://www:america.gov/st/democracyhrarabic/2010/june/20100615124025 ssissirdileo. 7045557.html

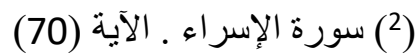

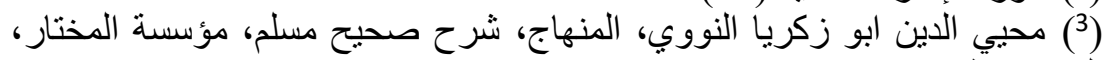

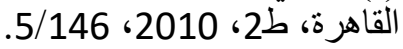




\section{ثانياً :- أهمية الدراسة:}

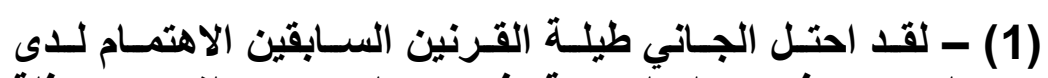

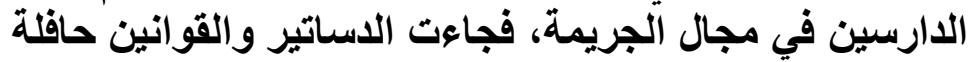

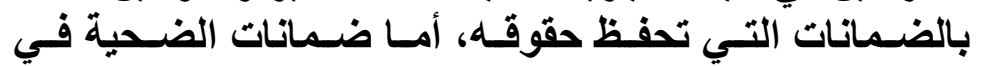

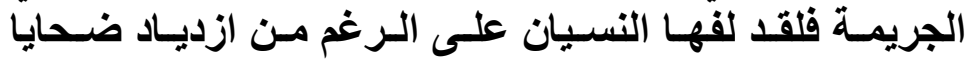

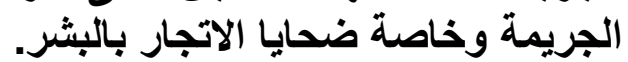

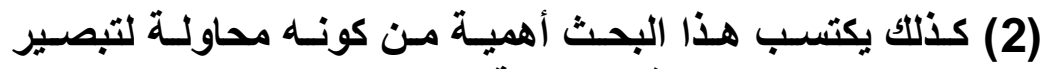

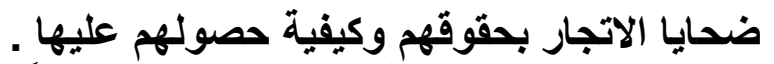

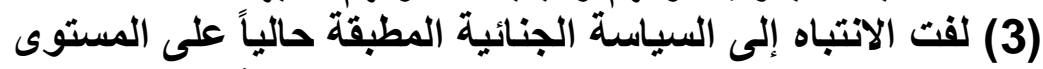

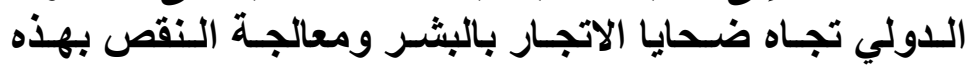

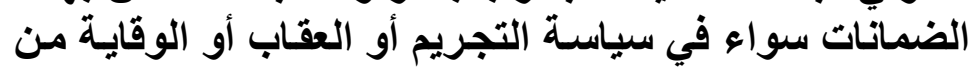

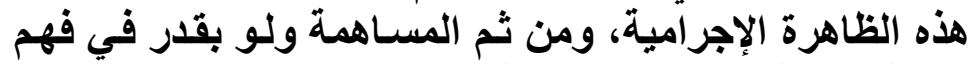

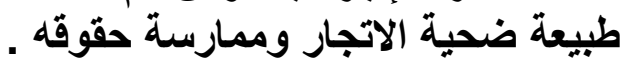

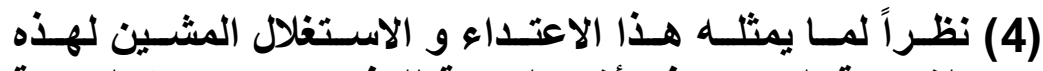

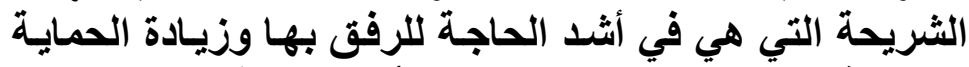

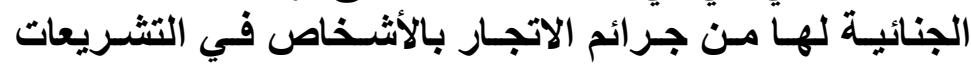
الوطنية العربية المتعلقة بمكافحة الاتجار بالبشان بالبش.

$$
\text { ثالثاً : أهداف الدراسة }
$$

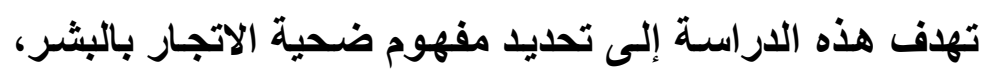

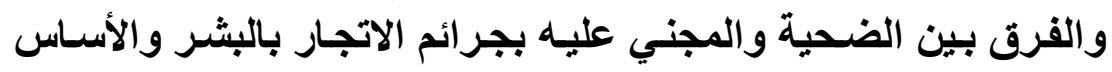

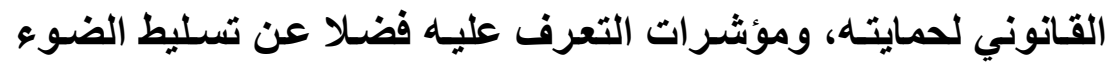

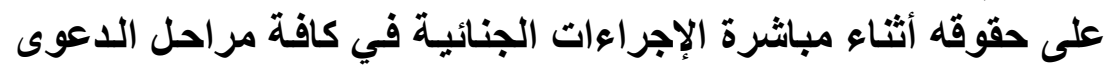

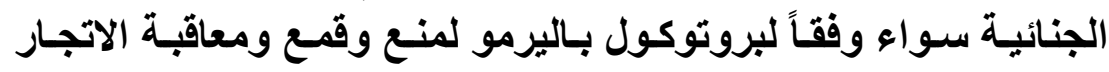

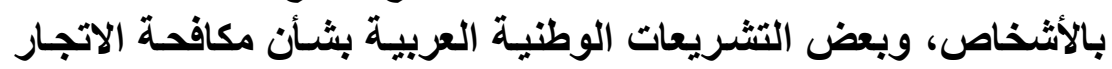




$$
\text { رابعاً:- أسباب الدراسة:- }
$$

تتلخص أسباب الاراسة في المسائل الآتية:

1. تزايد هذه الظاهرة على المستويين الدولي والوطني،

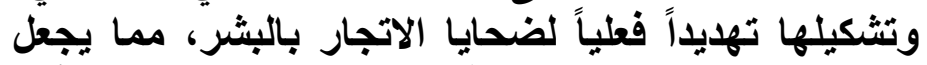

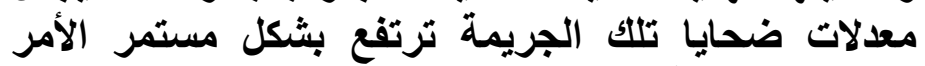

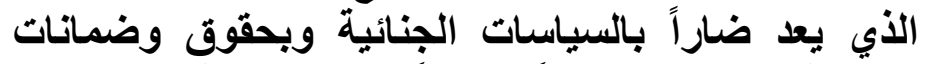

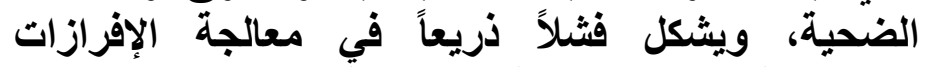

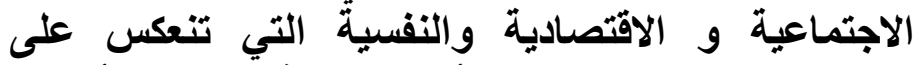

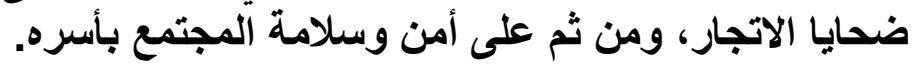

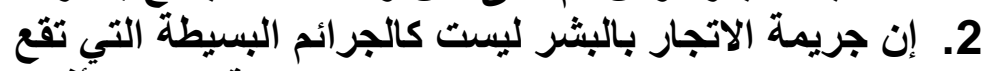

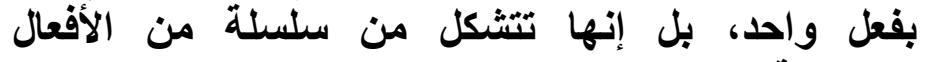

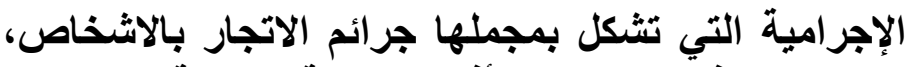

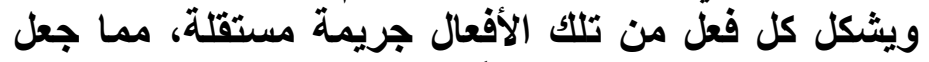

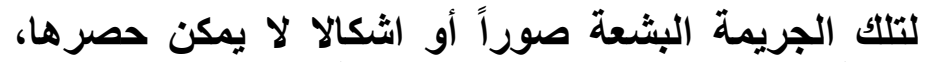

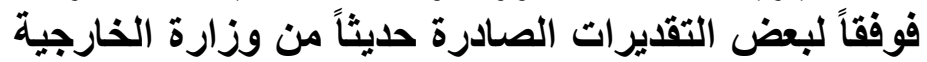

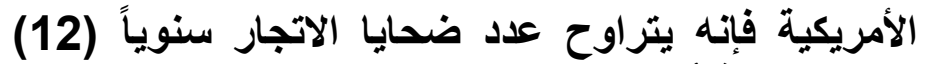

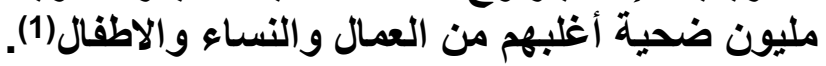

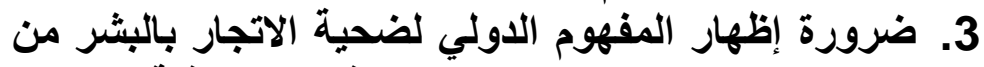

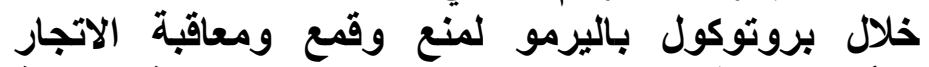

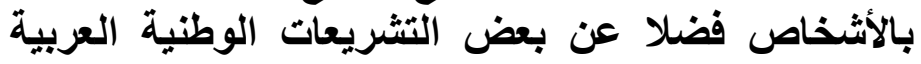

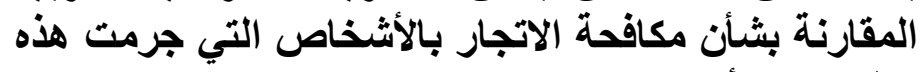

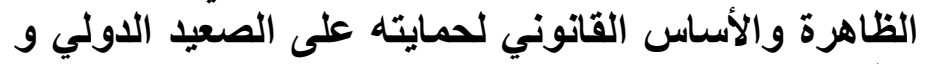

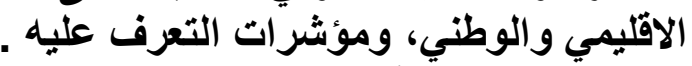

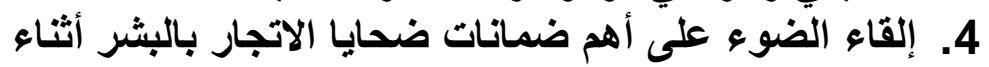

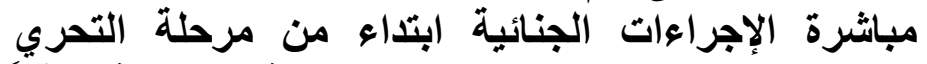

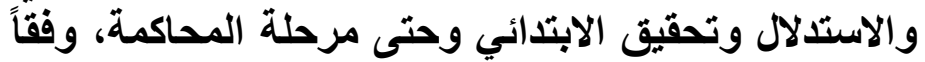

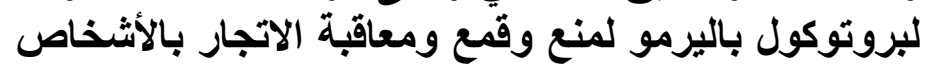

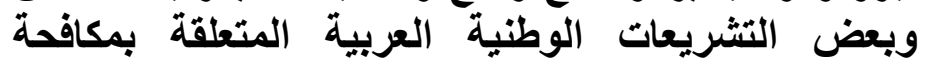

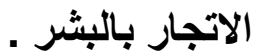

$$
\text { (1) التقرير السنوي العاشر حول الاتجار بالبشر ، تفاصيل التقرير على }
$$

http://www:america.gov/st/democracyhrarabic/2010/june/20100615124025 ssissirdileo. 7045557.html 
5. بيان أوجه القصور التي أنتابت نصوص بروتوكول باليرمو

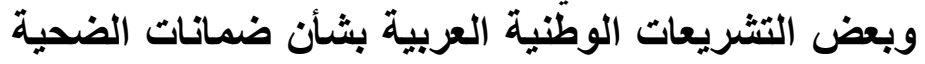

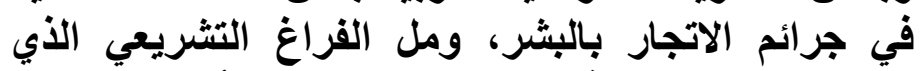

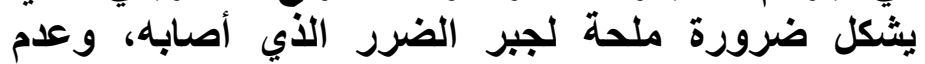

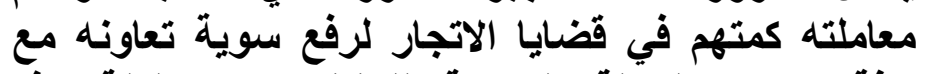

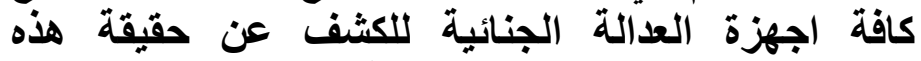

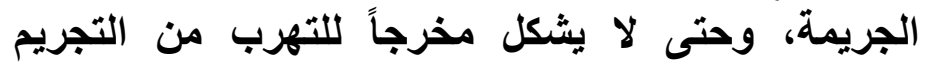
والعقاب يستفيل منه مرتكبيها.

$$
\text { خامساً :- أسئلة الدراسة }
$$

تقتضي الإجابة على بيان ضمانات الضحية في جرائم الاتجار بالبشر طرح الاسئلة الآتية :

السؤال الاول: ما مفهوم ضحية الاتجار بالبشر، والفرق بين الضحية والمجني عليه في هذه الجريمة.

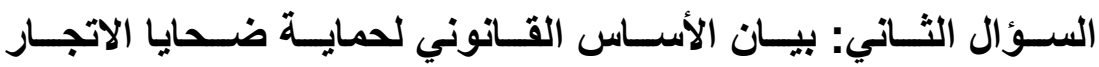

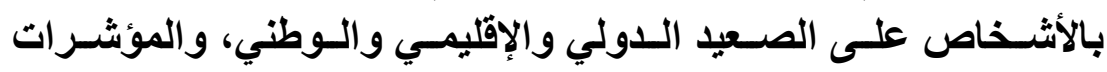

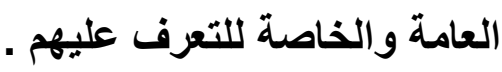

السؤال الثالث : ما هي أهم ضمانات الضحية أثتاء مباشرة الإجراءات التهات

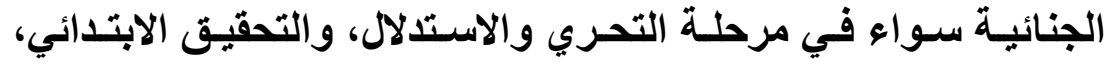

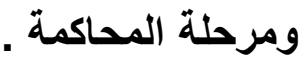




\section{سادساً : منهجية الدراسة}

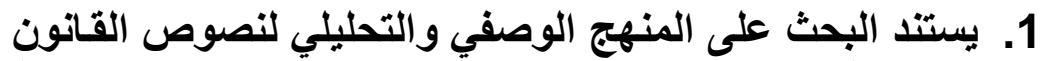

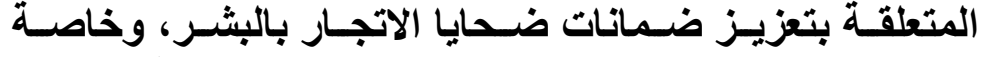

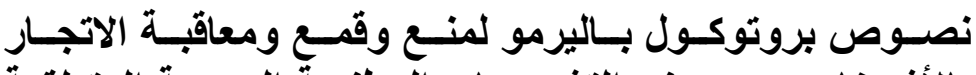

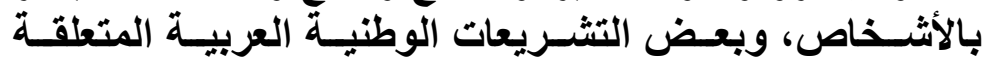

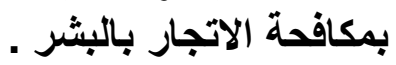

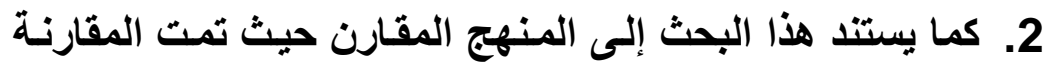

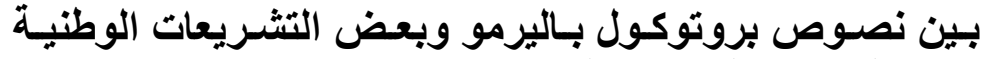

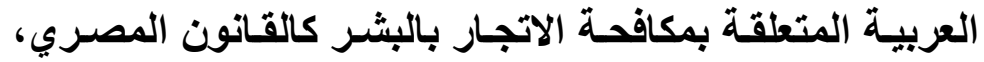

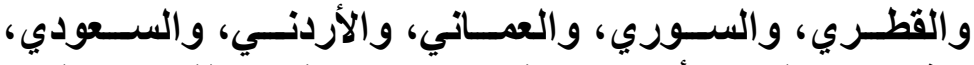

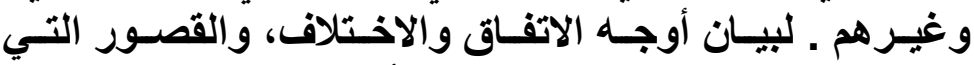

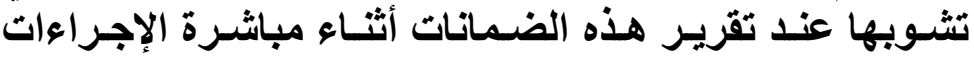

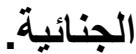

سابعاً :- تقتضي الإجابة على الأسئلة السابقة اتباع الخطة الآتية : المبحث الأول : ماهية الضحية في جرائم الاتجار بالبشر . المطلب الأول : مفهوم الضحية في جرائم الاتجار بالبشر .

المطلب الثـاني : الفرق بين الضحية والمجني عليهه بجرائم الاتجـار

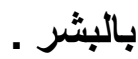

المطلب الثالث : الأساس القانوني لحماية ضحية الاتجار بالبشر . المطلب الرابع : المؤشرات الدالة على ضحية الاتجار بالبشر . المبحث الثاني : حقوق الضحية بجرائم الاتجار بالبشر أثناء الإجراءات

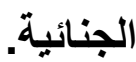

المطلب الاول : حقوق الضحية في مرحلة التحري والاستلال. المطلب الثاني : حقوق الضحية في مرحلة التحقيق الابتدائي. المطلب الثالث : حقوق الضحية في مرحلة المحاكمة . 


\section{المبحث الأول}

ماهية الضحية في جرائم الاتجار بالبشر

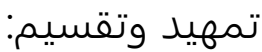

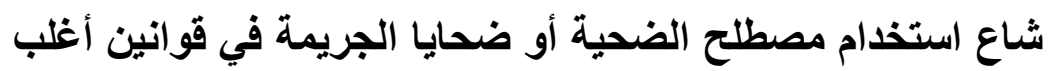

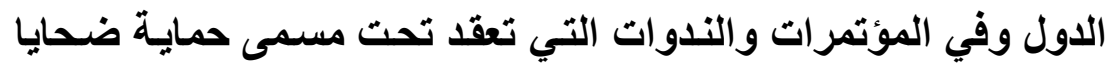

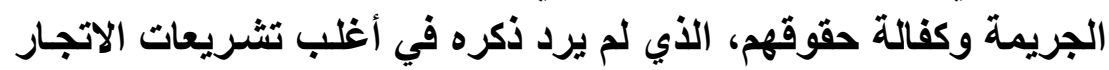

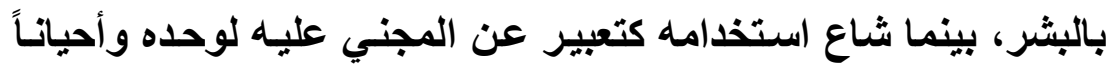

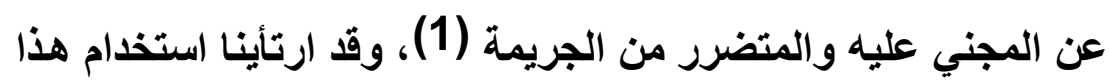

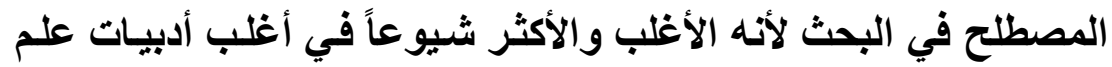

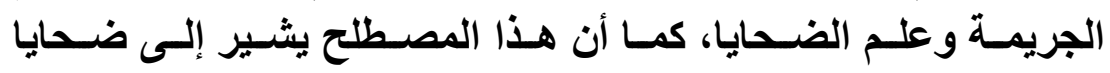

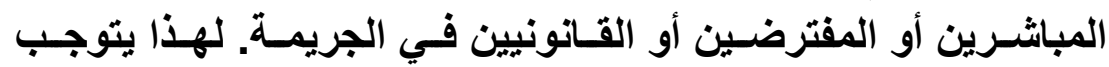
توضيح هذه المفهوم بالمطالب الآتية.

$$
\text { المطلب الأول }
$$

$$
\text { مفهوم الضحية في جرائم الاتجار بالبشر }
$$

إن مفهوم الضحية قايم قدم الإنسانية ذاتها ويرتبط بثكل لا يختلف

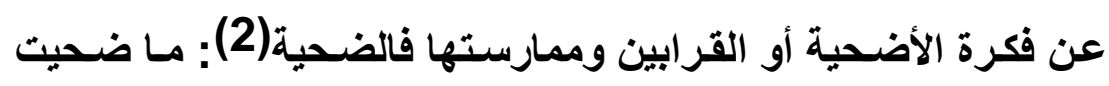

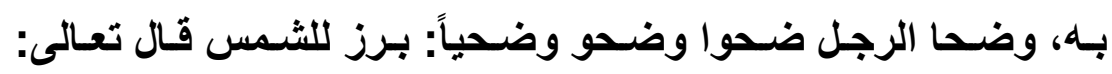

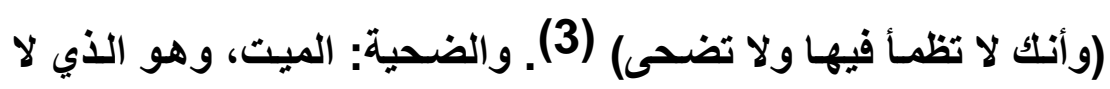

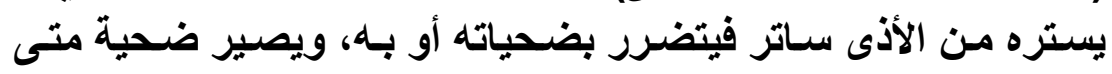

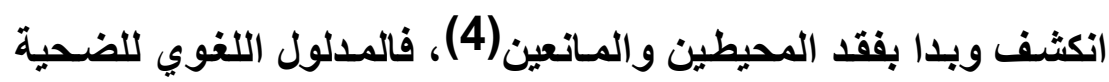

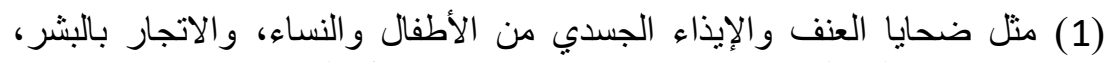

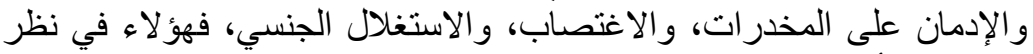

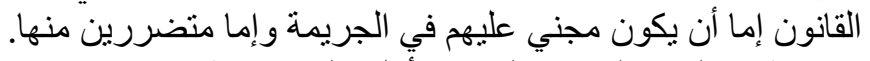
(2) ابن منظور، لسان العرب، الجزء الأول، القاهرة، ط23، 2013 2013، ص117.

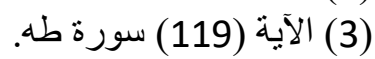

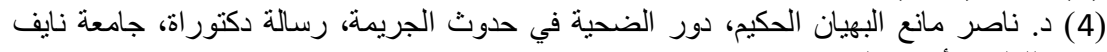
لل للعلوم الأمنية، الرياض، 2007م، ص15. 


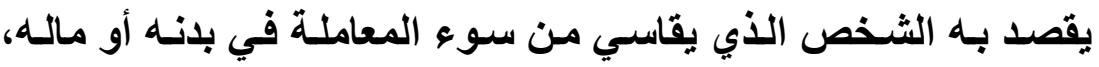

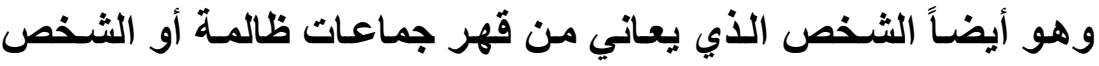

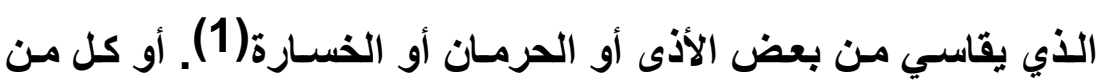

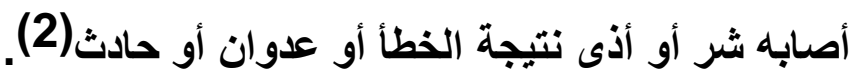

مما يقتضي الوقوف عند هذا المفهوم وتوضيحه في الفروع الآتية.

$$
\text { الفرع الأول }
$$

مفهوم الضحية وفقاً لبروتوكول باليرمو لمنع وقمع ومعاقبة الاتجار

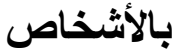

عرفت المسادة (3) مسن بروتوكسول بـاليرمو لمنـع وقمـع ومعاقبـة

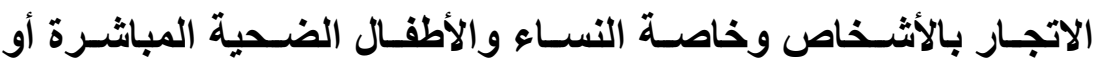

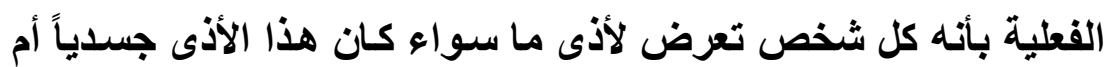

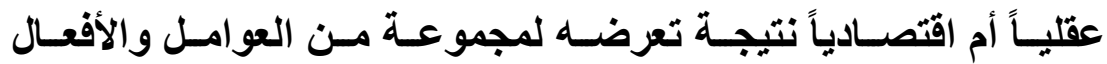
والوسـائل والأغراض كما هي محددة في المـادة (3/أ) من البروتوكول

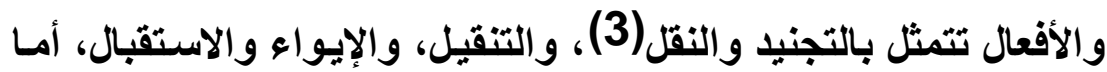

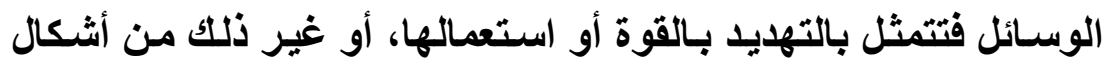

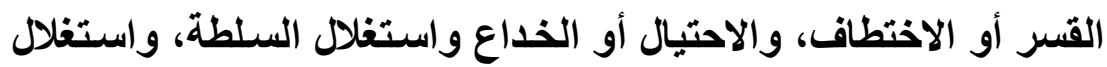
حالة استضعاف، أو إعطاء أو تلقي مبالغ مالية أو الو مزايا.

أما الأغراض فتتمثل في استغلال الغير للدعارة، أو سـائر الاستغلال

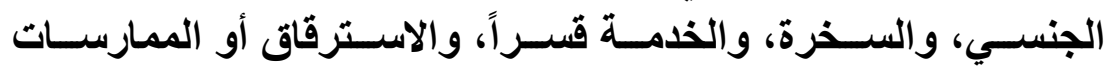

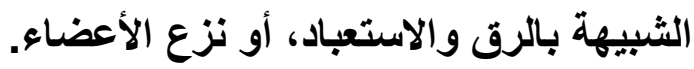

\footnotetext{
(1) د. عبد القادر عودة، التشريع الجنائي الإسلامي مقارناً بالقانون الوضعي، الجزء الأول، دار

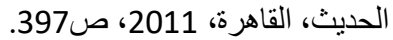

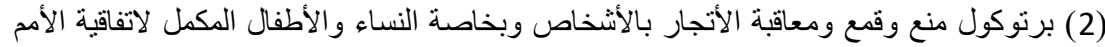

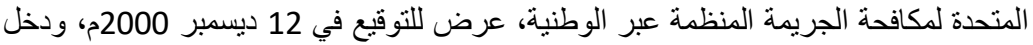
حيز النفاذ في 25 ديسمبر 2003.

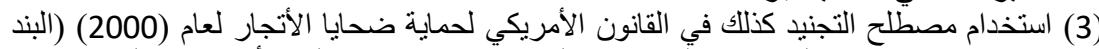

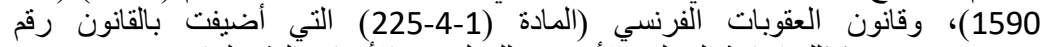
(2013/239)، وكذللك اتفاقية المجلس الأوروبي اللعمل ضد الأتجار بألبشر لعام 2005.
} 
وعند الرجوع إلى وثيقة الأعمال التحضيرية عن المفاوضسات بثـأن

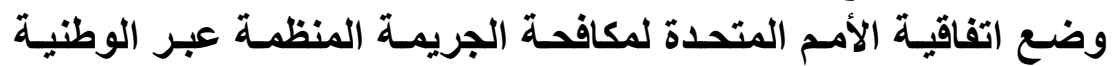

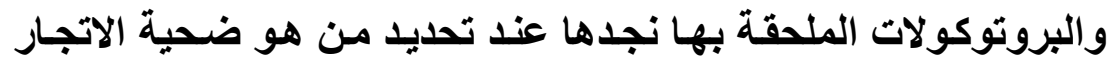

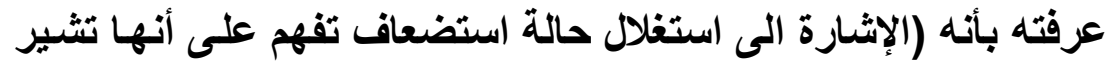

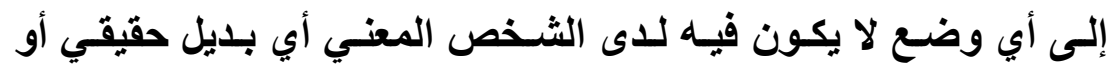

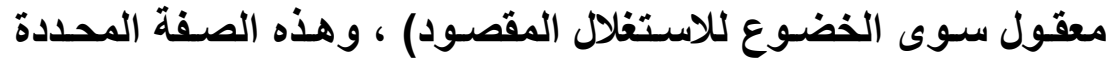

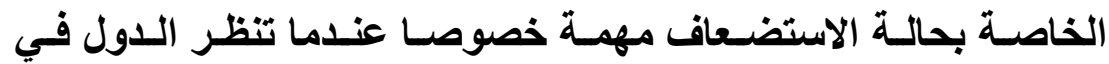

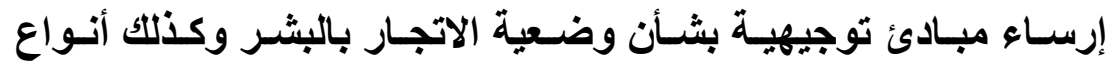

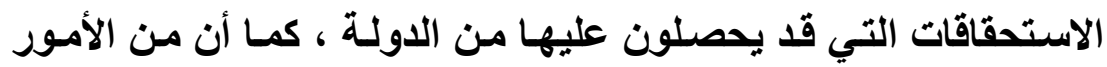

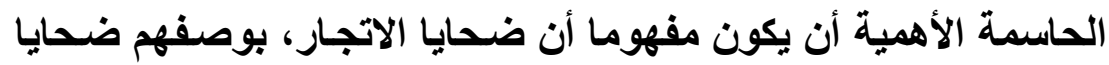

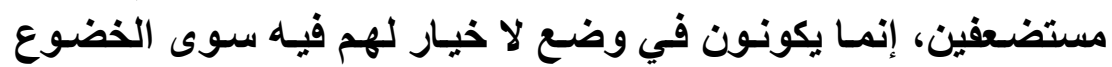

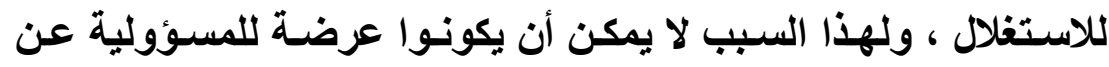

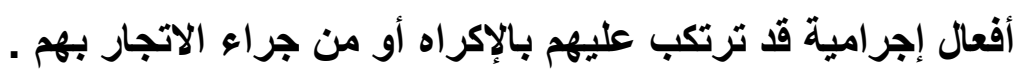

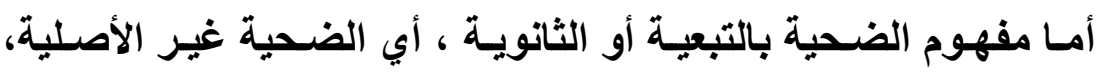

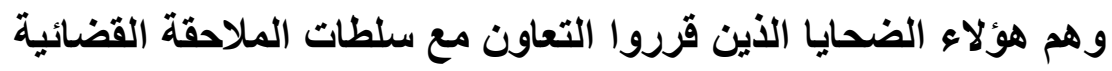

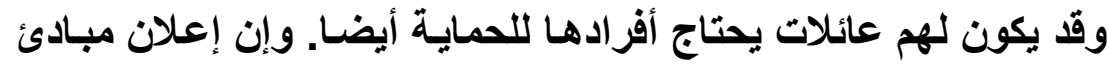

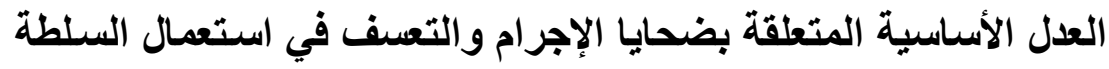

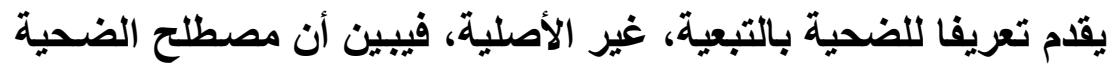

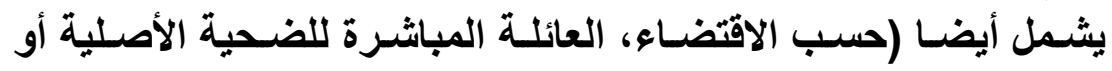

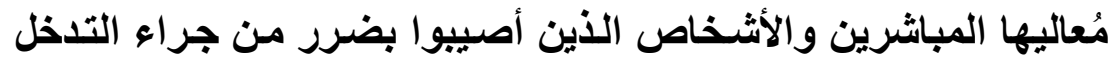
لمساعدة الضحايا في محنتهم أو لمنع الايذاء).

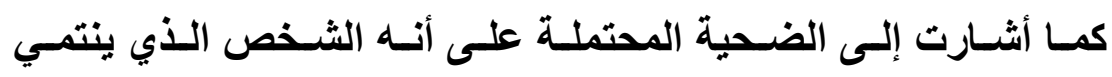

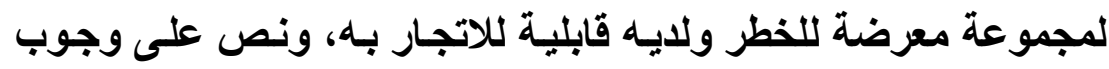

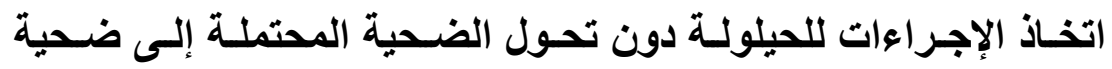

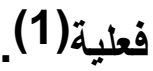

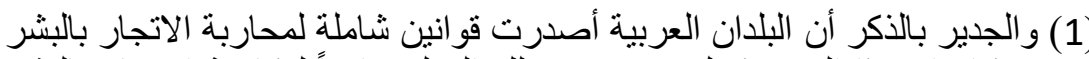

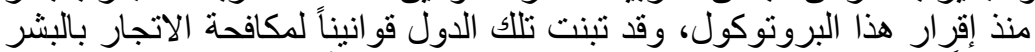

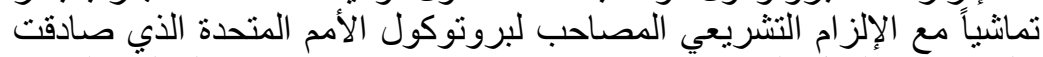
عليه معظم الدول العربية في تاريخ 21 اكتوبر 2011 وهي الأري المملكة العربية 


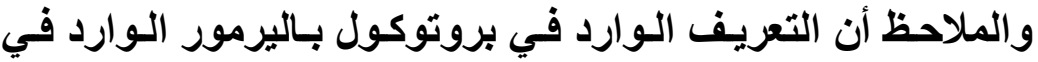

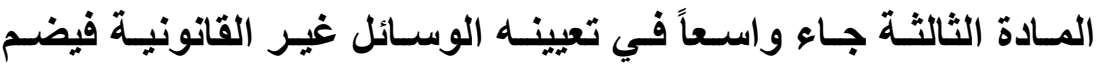

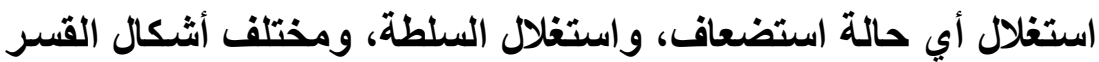

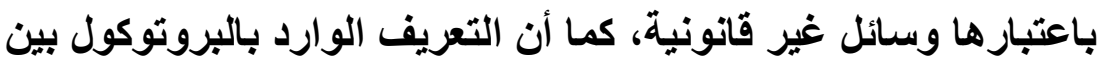

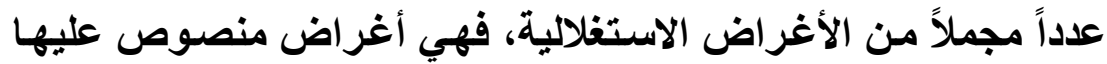

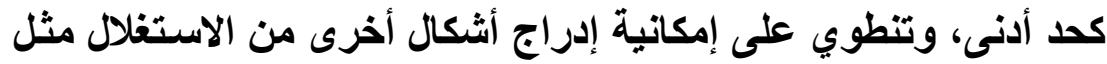

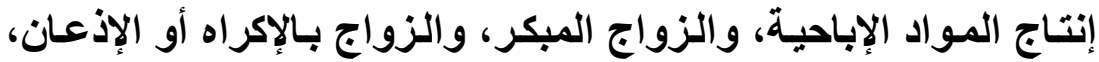

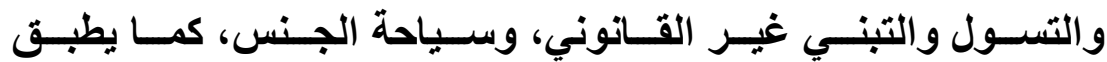

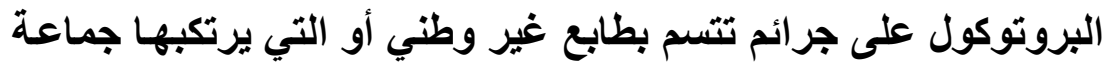

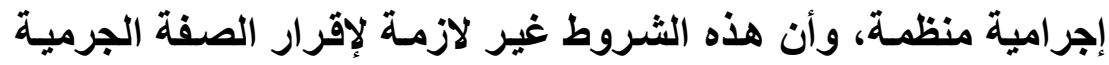

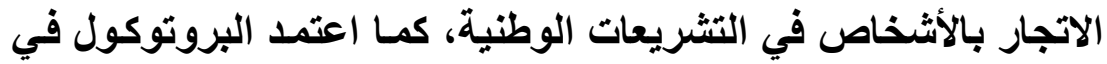

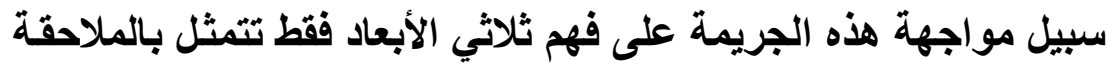
القضائية، والحماية والمنع.

$$
\text { الفرع الثاني }
$$

مفهوم الضحية وفقاً لمؤتمر الأمم المتحدة الثالث عشر بشأن منع

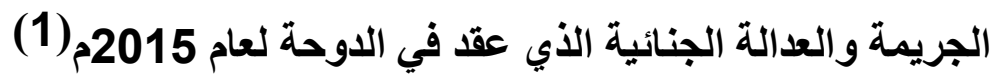

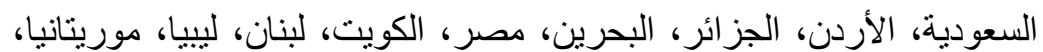

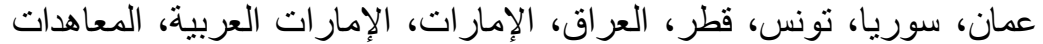

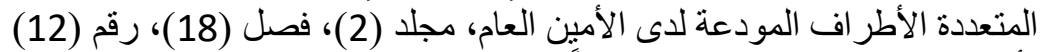

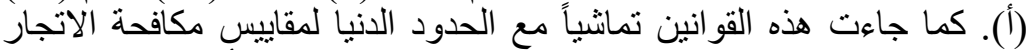

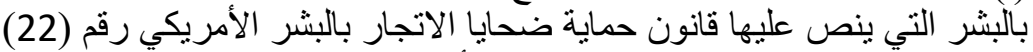

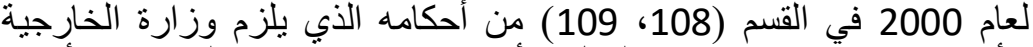

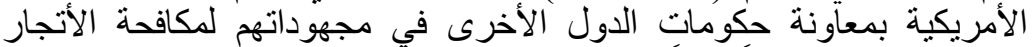

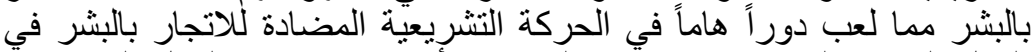

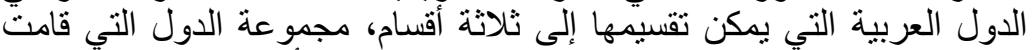

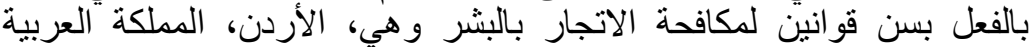

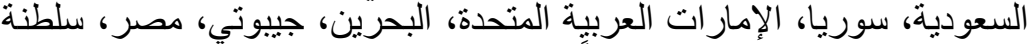

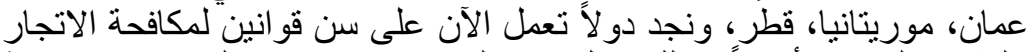

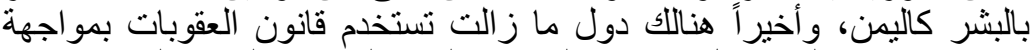

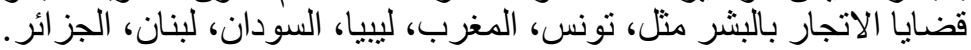

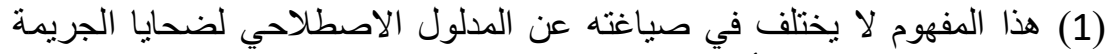

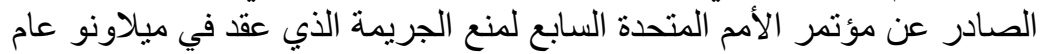


جاء المدلول الاصطلاحي لضحايا الاتجار بالبشر وفقاً لمؤتمر الأمـم

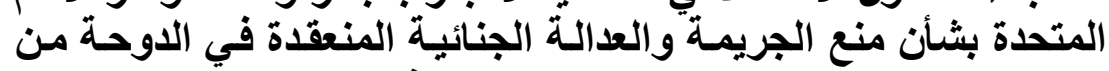
19-12 نيسان/إبريل 2015م محدد النطاق في محتواه ليشمل:

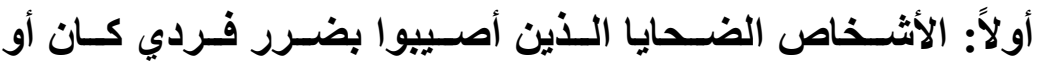

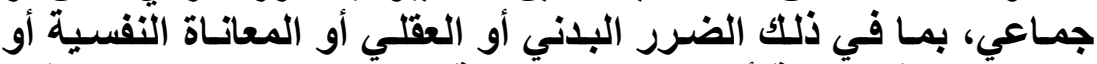

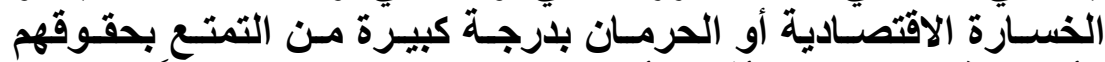

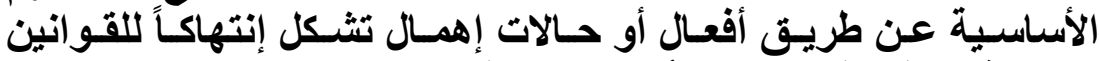

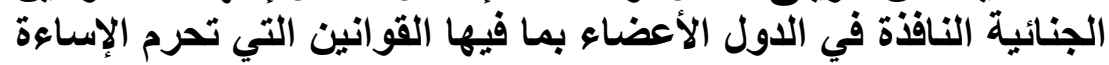
الجنائية لاستعمال السلطة النافة في الأول الأعة

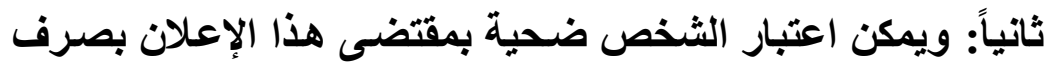

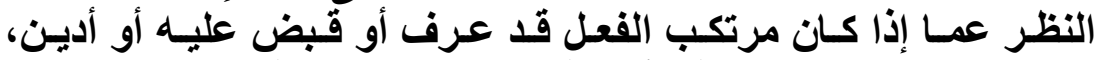

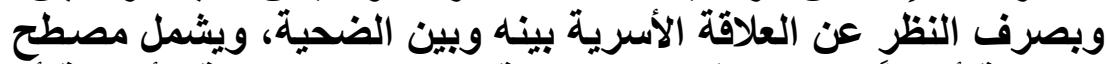

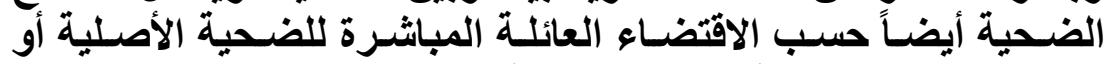

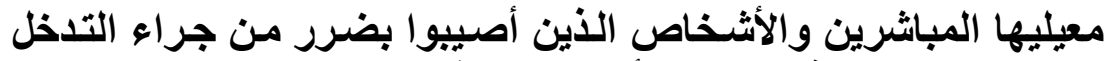

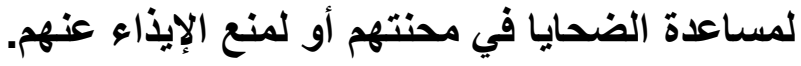

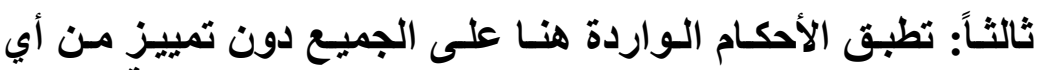

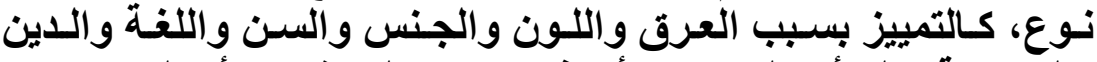

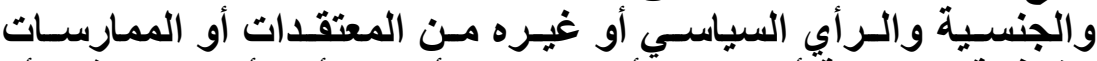

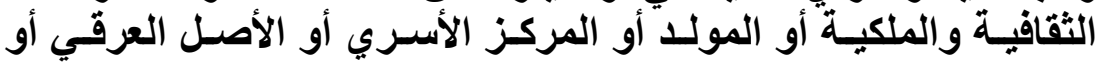

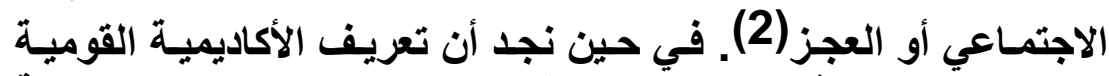

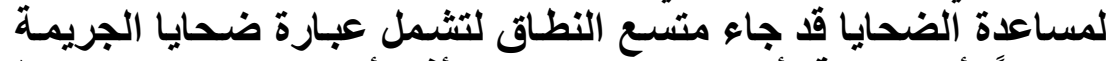

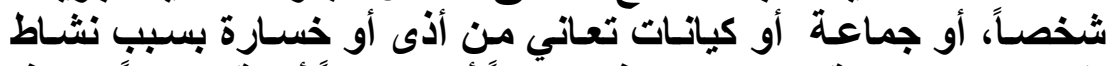

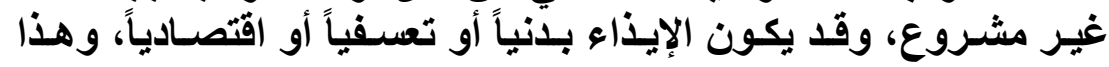

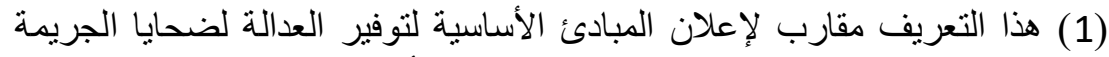

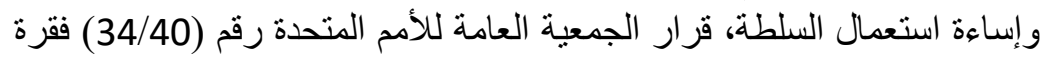
(1)، وثيقة الأمم المتحدة رقم A/RES/40/34/Annex، بتاريخ 29 نوفمبر .1985

(2) مؤتمر الأمم المتحدة الثالث عشر لمنع الجريمة والعدالة الجنائية، الدوحة، 2015، وثائق الأمم المتحدة رقم A/conf.222/11. 


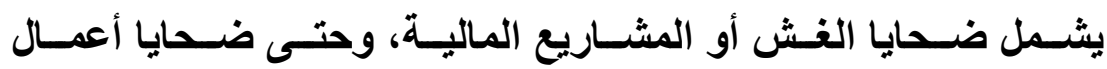

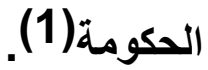

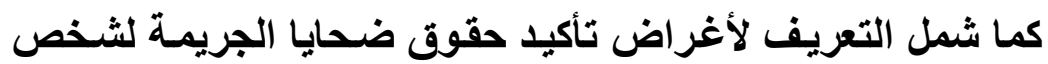

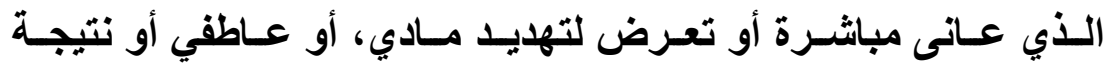

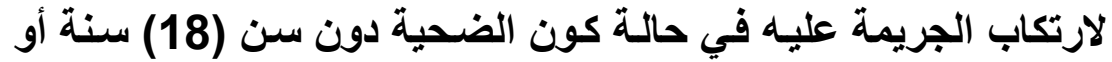

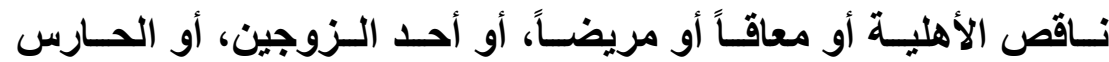

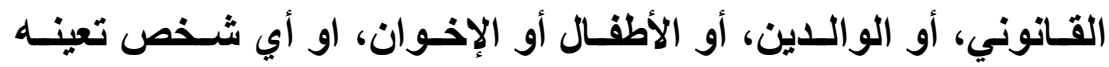

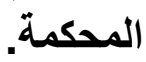

فضلاً عن كونه مؤسسة أو كياناً أو ممثل للمؤسسة قانوناً، بصرف

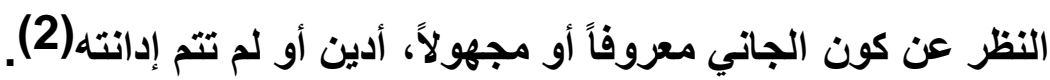

والملاحظ أن التعريف الذي تبنته الأمم المتحدة بثـأن الضحايا هو

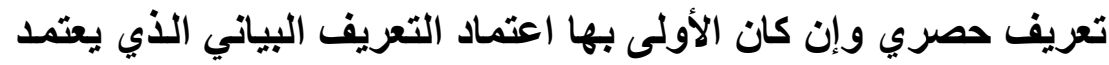

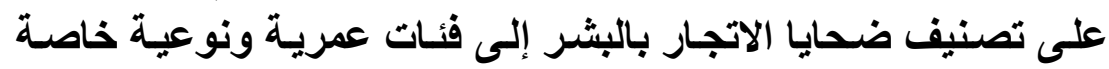

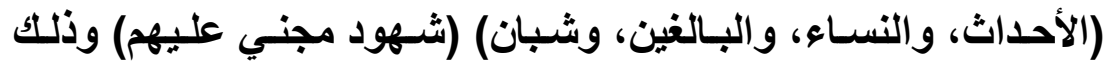

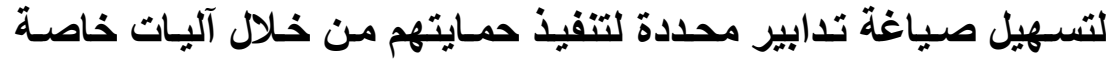

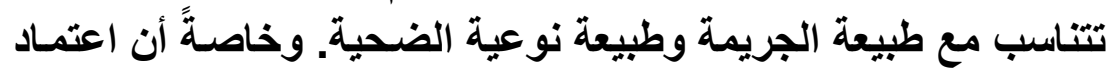

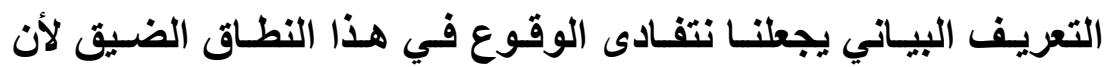

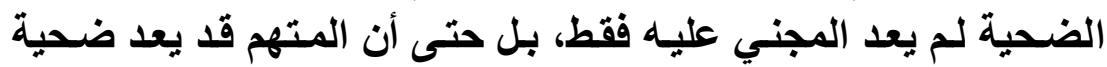

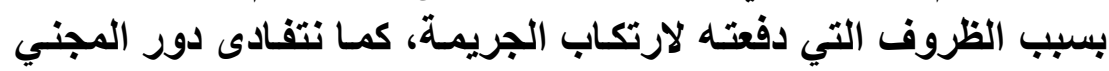

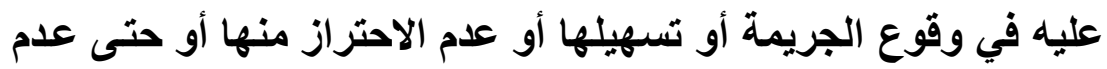
الإبلاغ عنها (3). ولكن يلاحظ إذا كان شخص الضحية طفلاً فإنه يعتبر

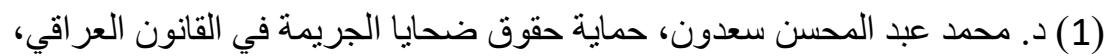
مجلة الالتزامات والعقود، المعهد التقني، العدد 2، النجف، العراق، فئ، 2015،

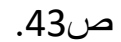

(2) د. محمد الأمين البشري، علم ضحايا الجريمة وتطبيقاته في الدول العربية، مركز

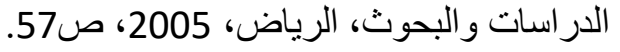
د. محد محب الدين مؤنس، تعويض الرياض، ضحايا الجريمة، جامعة نايف العربية للعلوم

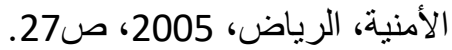

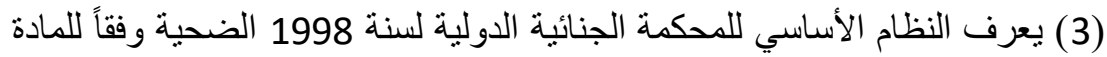
(85) من القواعد الإجرائية وقواعد الإثبات بأنه اليدل لفظ الضحية على الضية 


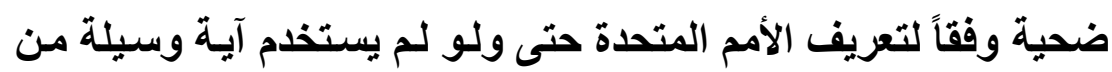

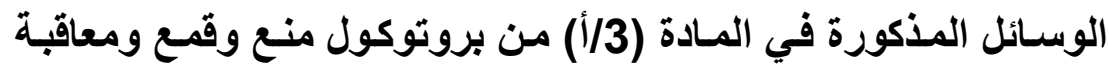
الاتجار بالأثخاص خاصة النساء الئادة والأطفال.

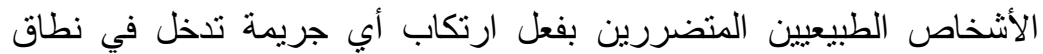

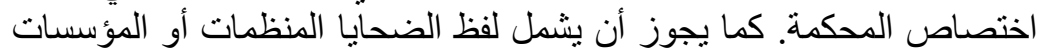

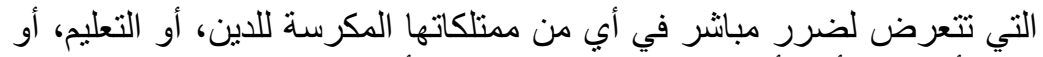

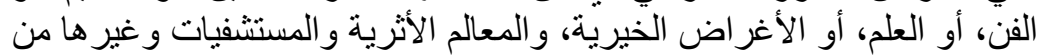

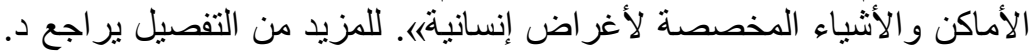

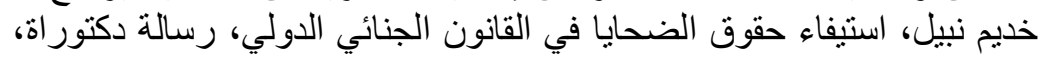
جامعة بسكرة، الجز ائر، 2012م، صناف الطيان في وما بعدها. 
مفهوم الضحية في التشريعات العربية لمكافحة الاتجار بالبشر

بـالرجوع إلى كافـة التشـريعات العربيـة المتعلقة بمحاربـة الاتجـار

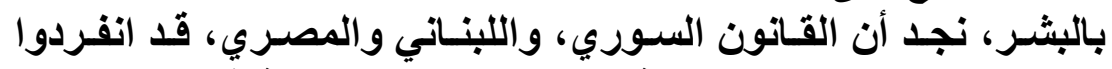

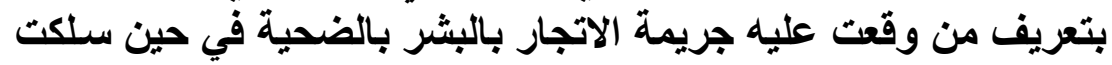

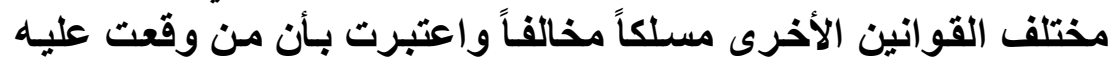

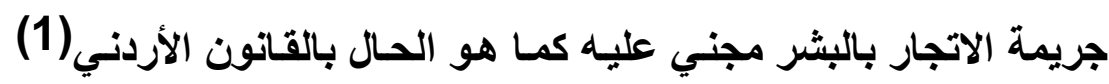

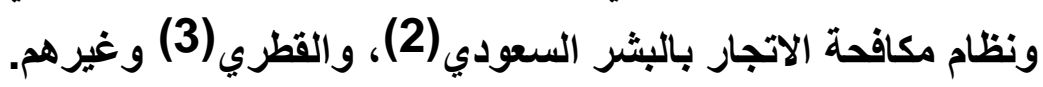
فقد نصت الفقرة الثالثة من المـادة الرابعة من قانون منع الأتجار بالاشخاص السوري رقم (3) لسنة (2010) على تعريف الضحية الضحة بأنسه

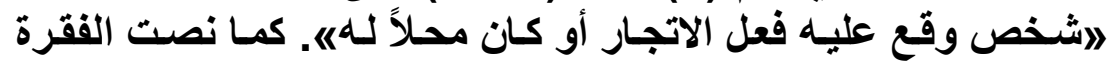

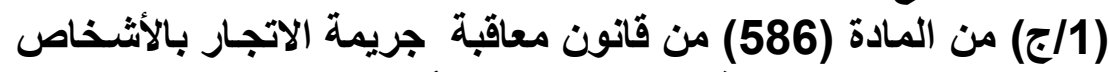

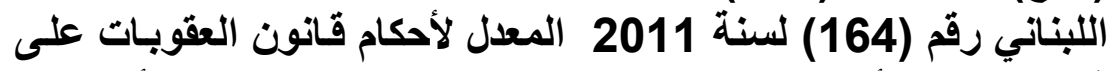

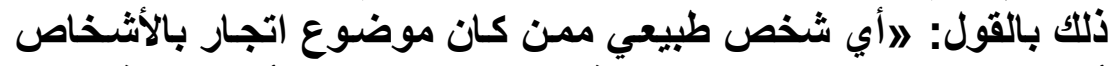

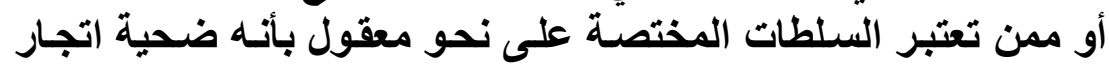

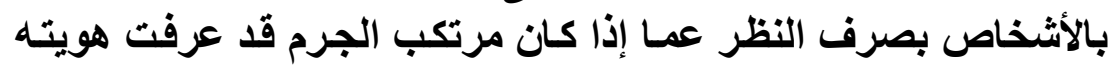
أو قبض عليه أو حوكم أو أدينها.

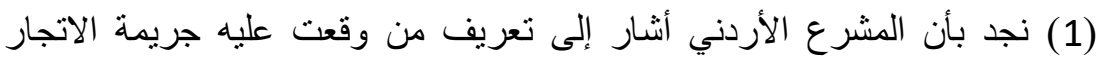

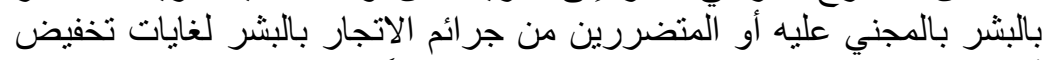

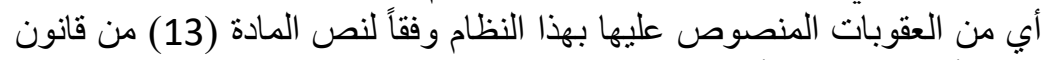

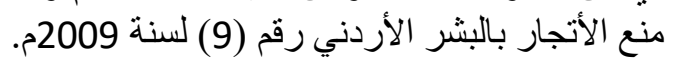

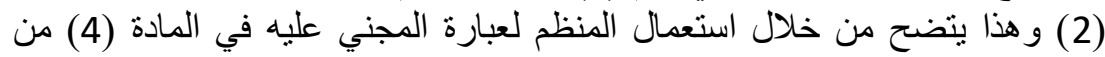

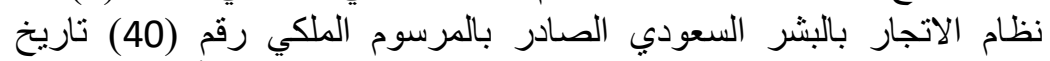

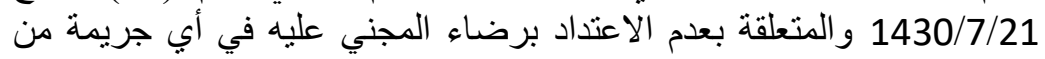

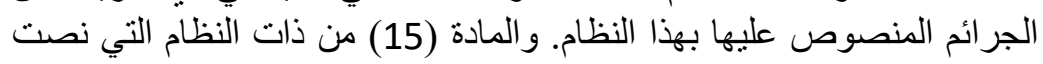

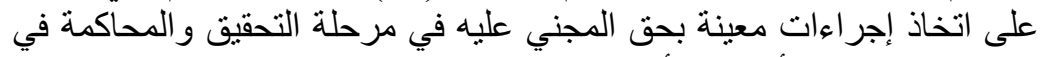
جريمة من جر ائم الأتجار بالأشخاص.

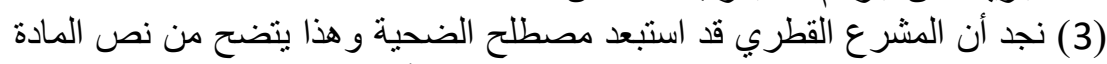

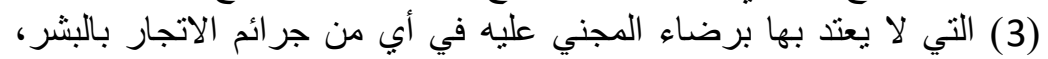

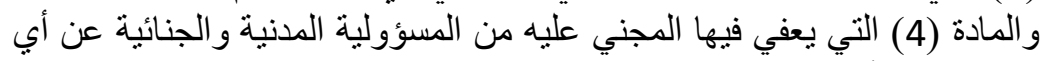

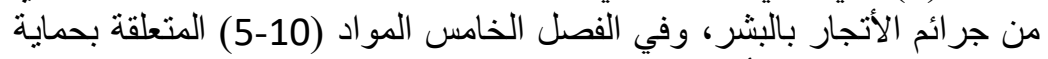
المجني عليه بجر ائم الأتجار بالبشر. 
و هذا من نصت عليه الفقرة الثالثة من المادة الأولى من قانون بأن

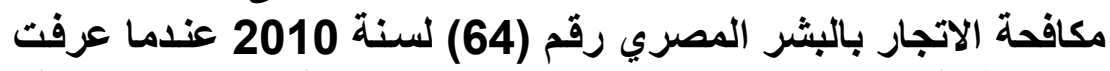

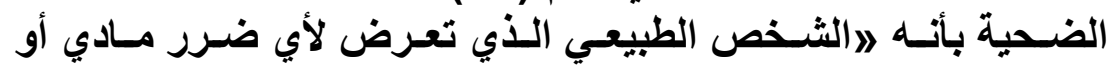

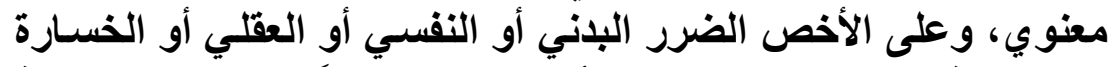

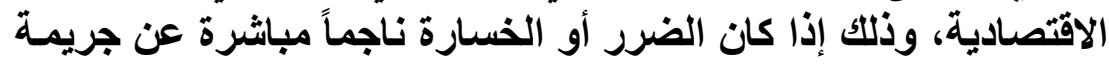

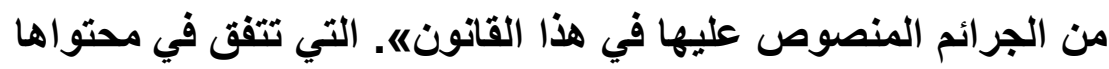

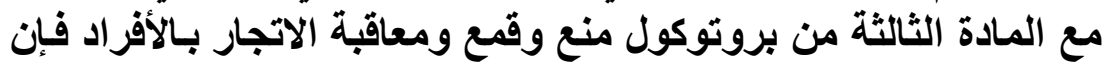

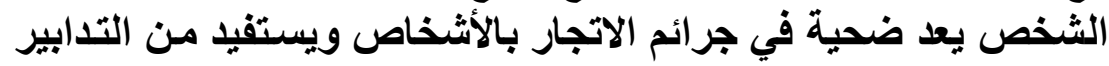

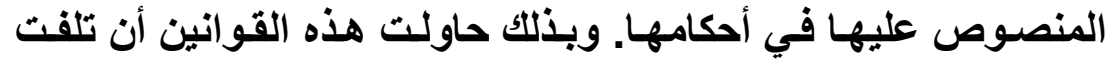

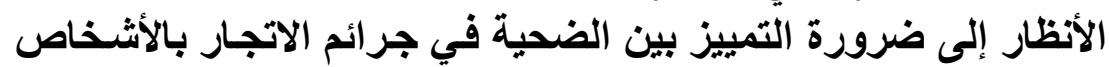

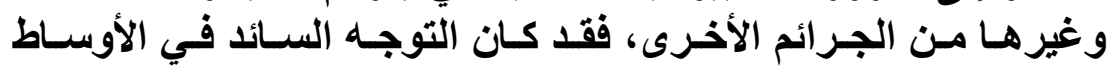

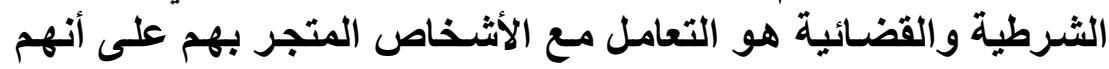

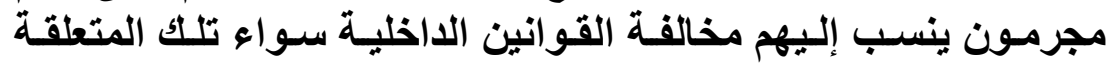
بالدعارة أو العمالة أو الهجرة والإقامة.

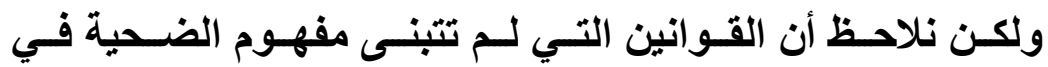

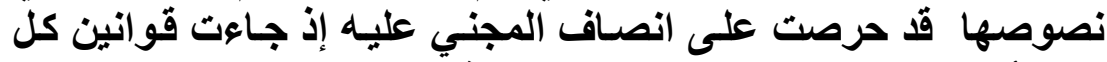

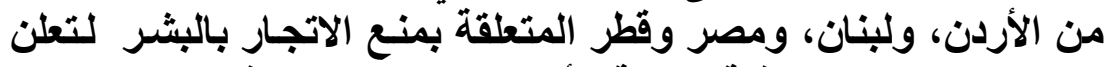

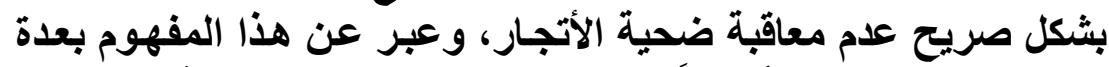

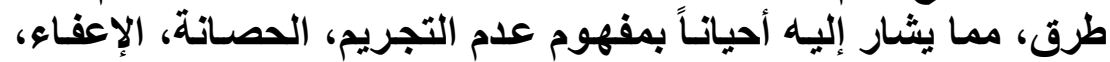

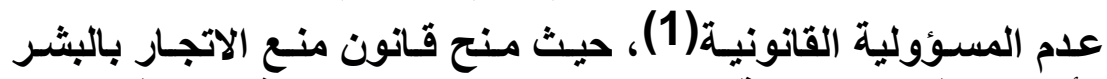

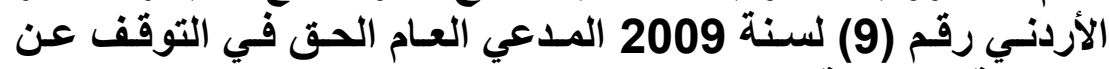

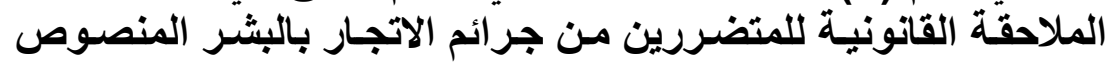

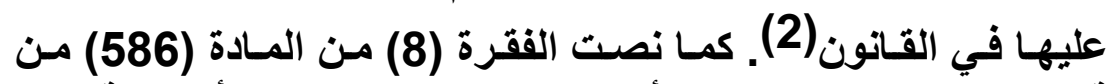

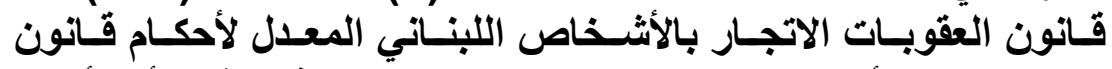

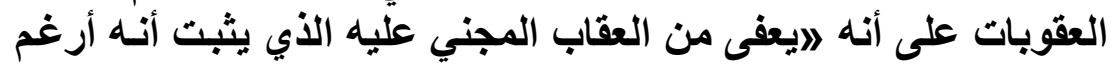

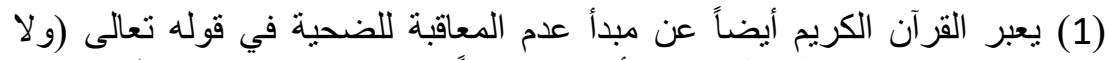

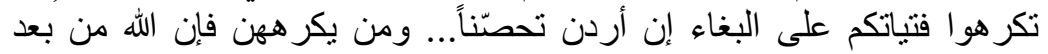

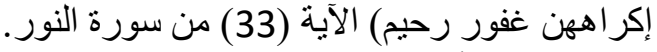

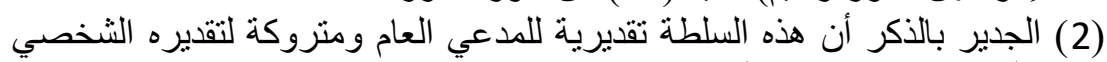
وأن القانون لا يحتوي أي نص إرشادي لنطبيق تلك السلطة. 
على ارتكاب أفعال معاقب عليها في القانون أو خالف شرط الإقامة أو

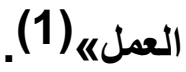

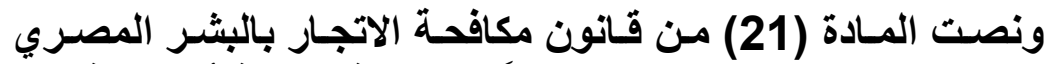

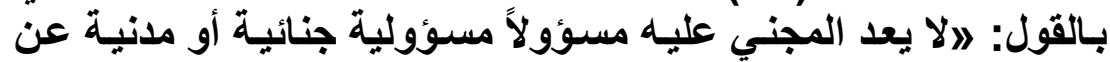

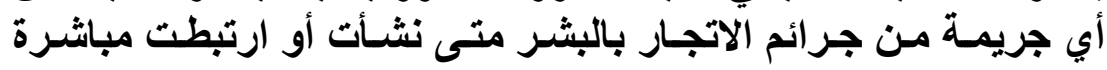

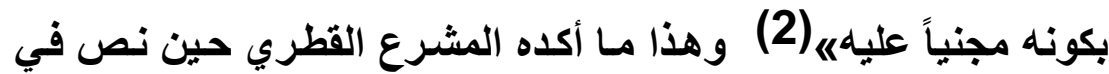

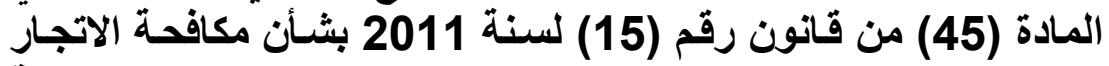

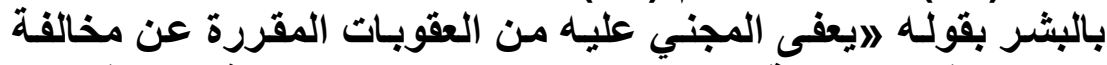

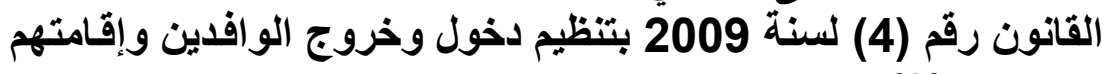

وكفالتهمه(3).

(1) قانون رقم (164) الصادر بتاريخ 24 أغسطس 2011 >(قانون معاقبة جريمة الاتجار بالبشر).

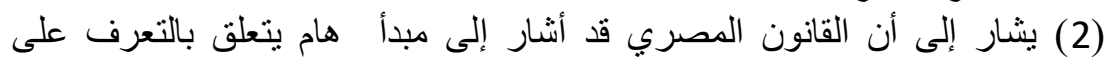

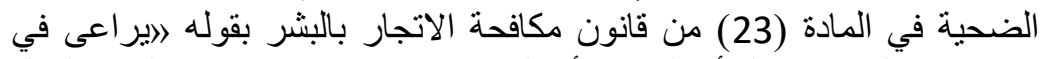

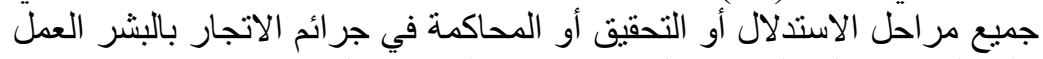

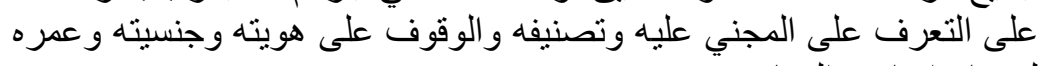
لضمان إبعاد يد الجناة عنها).

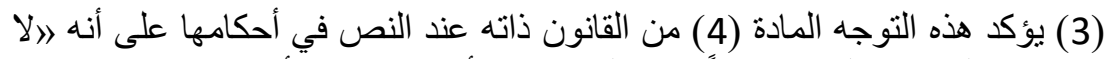

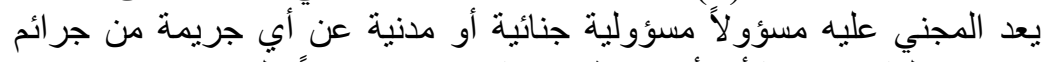
الاتجار بالبشر متى نشأت أو ارتبطت مباشرة بكونه مجنياً عليهها. 
المطلب الثاني

الفرق بين الضحية والمجني عليه بجرائم الاتجار بالبشر

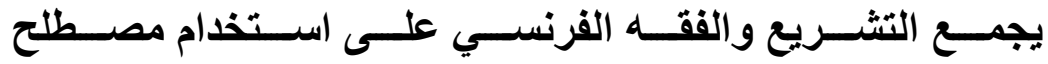

(Victime)

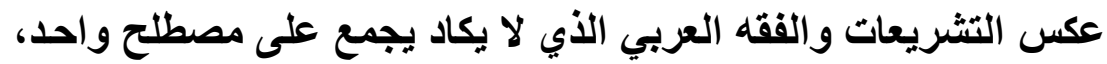

فتارة يستخدم مصطلح الضحية وتارة مصطلح المجني عليه(2).

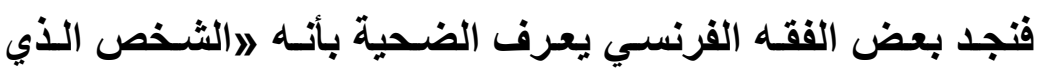

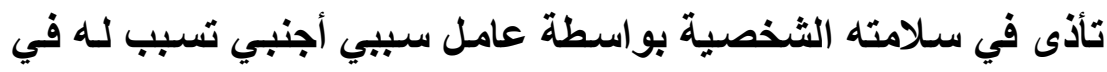

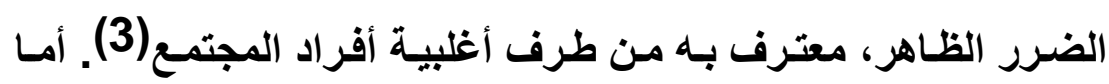

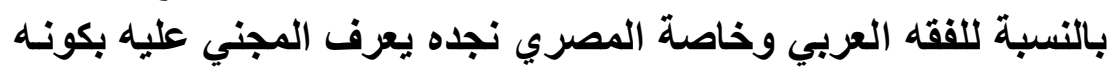

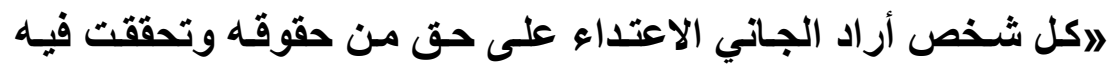

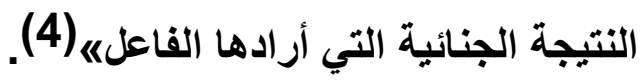

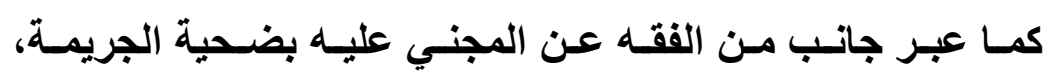

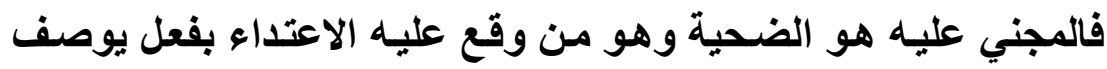

(1) و هي مشتقة من الأصل اللاتيني (Victima) التي تقابل بدور ها اللفظية الإغريقية

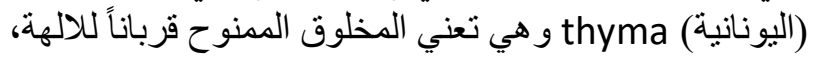

- Voir Ge'rard lopez: Victimologie, Dalloz, paris, 1997, p.31.

- Et C'est le même sens situe' dans le Rebert, dictionn aire d'anjourd'hui. France loisirs, paris, 2005 le mot.

(2) د. صلاح عبد المتعال، الدراسة العلمية للمجني عليه، دار المعارف، القاهرة،

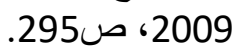

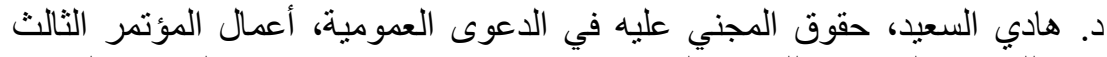

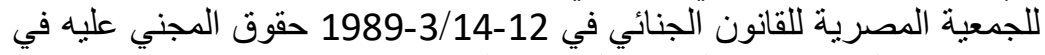
الإجراءات الجنائية، دار النهضة العربية، القانية فئرة، 2009 ص221.

)3( Et dans le même sens on tyoure "La victime s,entend ge'ne'ralements de la personne qui subit et qui souFFre soit des agissements d'autrui, soit d'e'venement nefastes"

Francoise ALT-MAES: "Le concept de La victim en droit civil eten droit pénal" RSC, no=1994, p.35.

ده. حسن صادق المرصفاوي، الدعوى المدنية أمام المحاكم الجنائية، دار

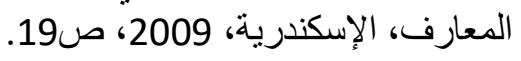


بالقـانون بأنسه جريمـة(1)، ومن ثم يرى أن المفهوم القانوني للمجني عليه مرن يستعصي على التحديد (2). كمـا يعرف المجني عليه بأنسه

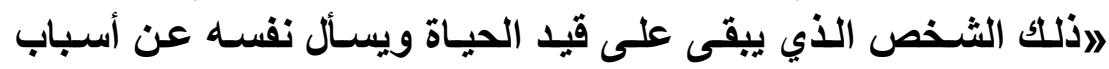

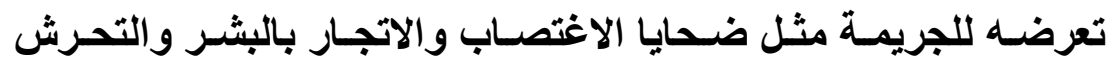

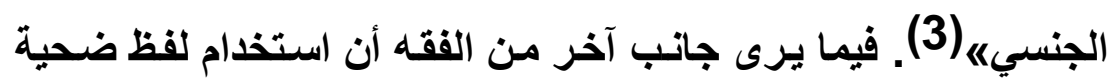

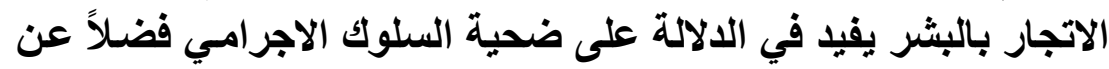

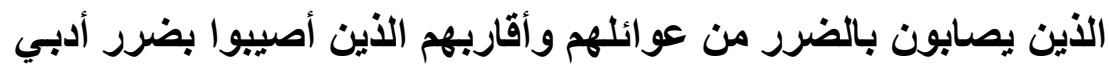

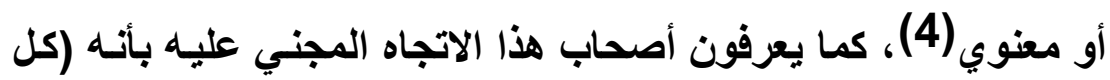

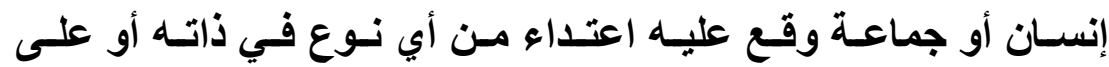

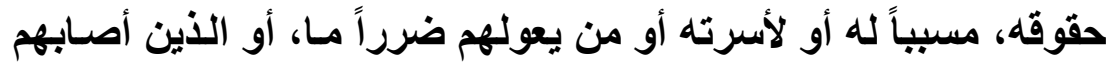

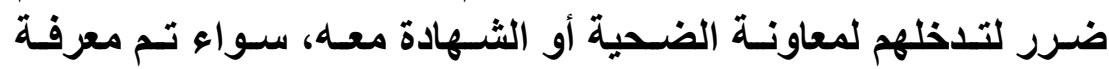

(1) د. هادي السعيد، حقوق المجني عليه في الدعوى العمومية، مرجع سابق،

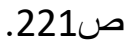

(2) د. إبر اهيم ناجي بدور ، مفهوم الضحية بين نظرية علم الاجتماع و النظرية العامة الإية

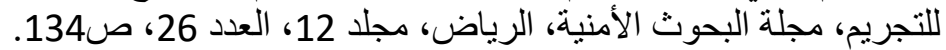
د. مسعود محمد مرسي، شكوى المجني الأني عليه، رسالة دكتوراة، أكاديمية الثرطة،

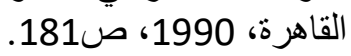

د. أحمد عبد اللطيف الفقي، الحماية الجنائية لحقوق ضاحيا الجريمة، دار النهضة

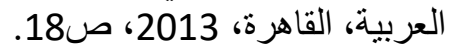

(3) Sandra walkat: criminology the basics, willaan, 2007, p48.

Bonnie.S.fisher. Steven. P. lab; Encyclopedia victimology and crime preventation. Volume1 sage publications, california, 2010. p.999

(4) د. سري محمود صيام، حق الضحايا في الحصول على التعويض، أعمال

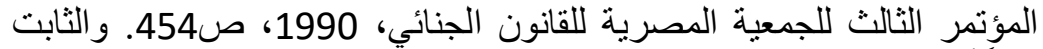

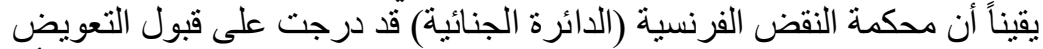

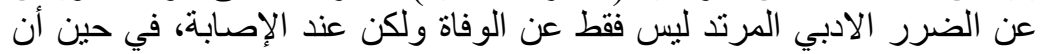

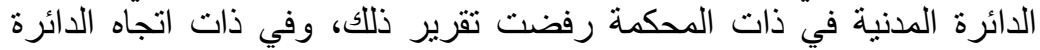

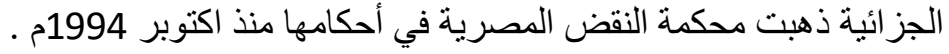


المعتدي، أو لم يتم معرفته، سواء أدين في محاكمته أم لم يلان، أو كان

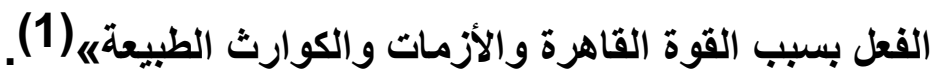

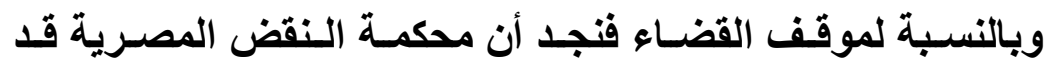

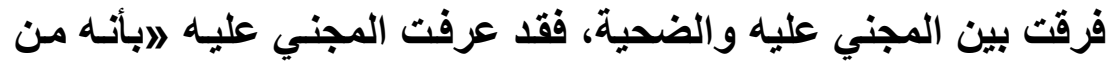

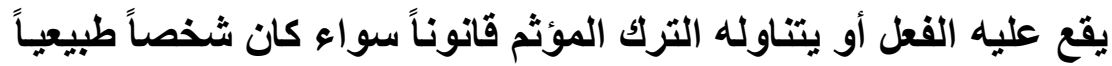

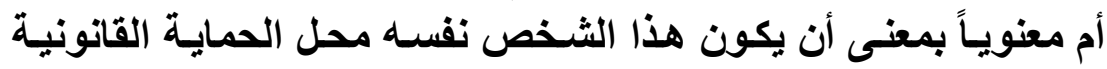

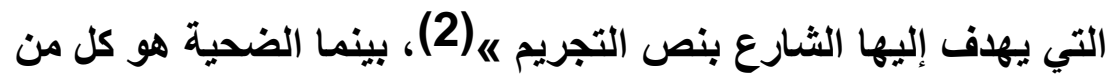

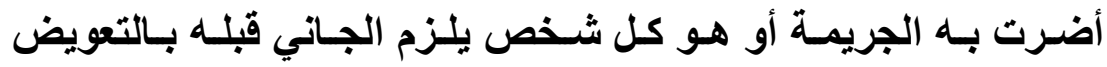

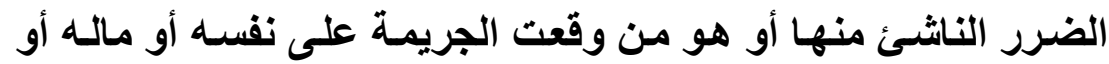

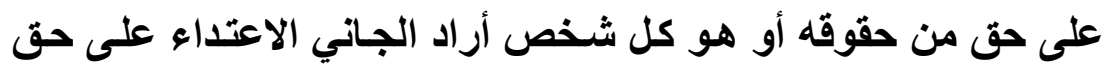

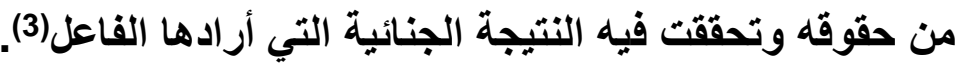

ويتضح مما سبق الفرق بين الضحية والمجني عليه وهو أن الثاني من

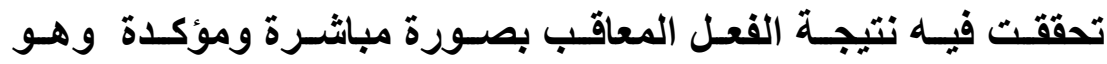

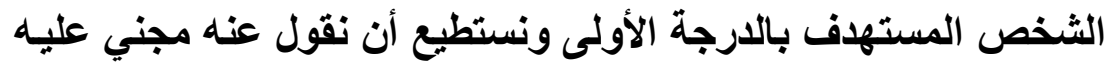

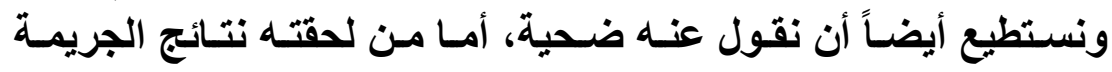

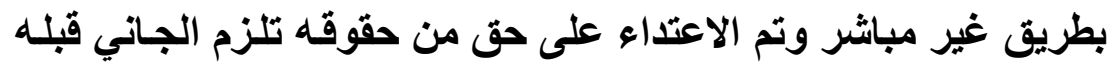

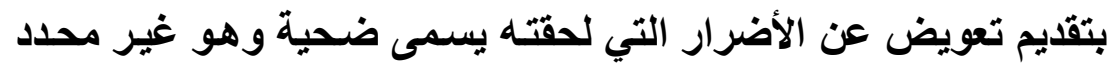

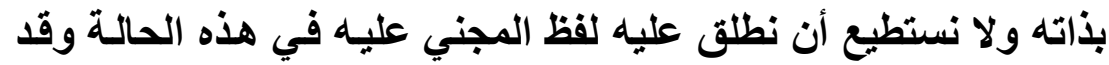

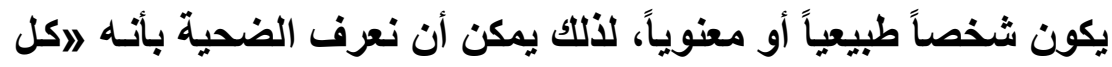

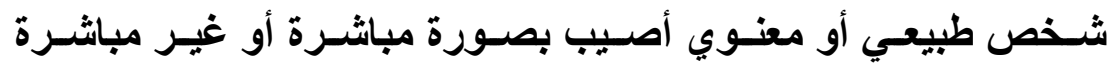
ومؤكدة بأضرار مادية أو أدبية بفعل سلوك الاتجـار بالبشر محلياً كـان

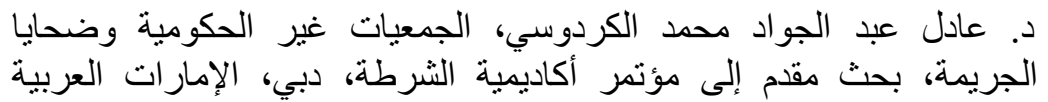

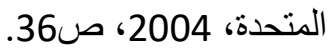

(2) د. المستشار الشوربجي البشري محمد، حقوق ضحايا الجريمة بين مقتضيات

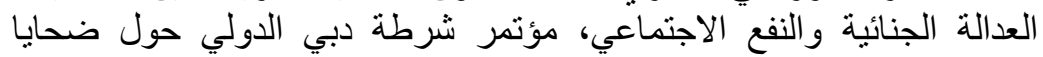

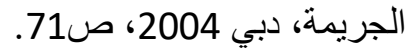
(3) د. ناصر مانع آل بهيان الحكيم، دور الضحية في في حدوث الجية الجريمة، رسالة

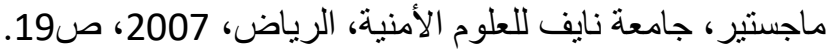


أو دولياً عن طريق أفعال عمدية، أو غير عمدية. ويتسع هذا المفهوم ليشمل من عانى من آثار الجريمة وليس المجني علئ أليه وحده.

ومما يؤكل توجهنا هذا مـا نصت عليه المـادة (13) من قانون مكافحة

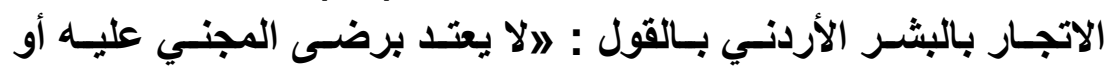

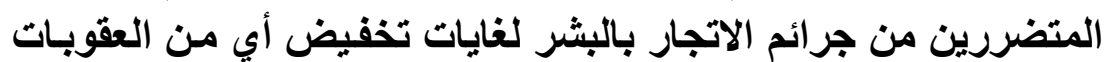
المنصوص عليها في هذا القانونه(1).

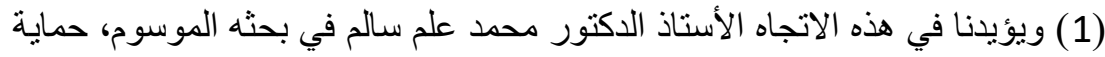
ضحايا الجريمة في مرحلة النحقيق الابتدائي، مجلة القانون، جامعة بابل، ع1، حلـ 


\title{
المطلب الثالث
}

الأساس القانوني لحماية ضحية الاتجار بالبشر

\author{
الفرع الأول \\ في مجال التثريعات الدولية
}

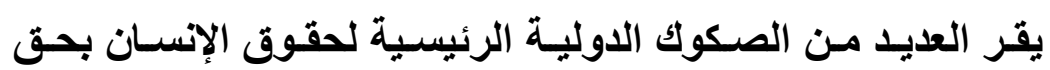

ضحايا انتهاكات حقوق الإنسان في سبيل الحصول على إنصاف فعال.

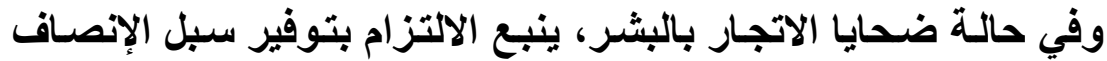

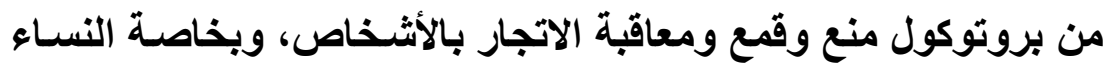

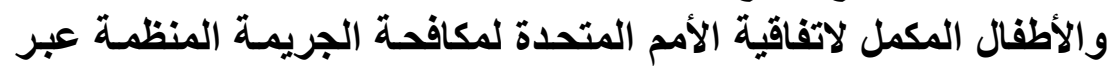

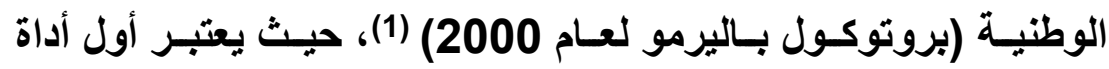

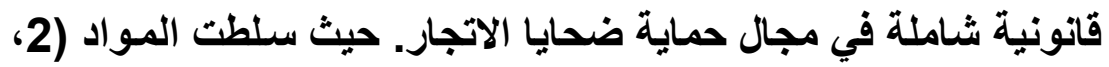

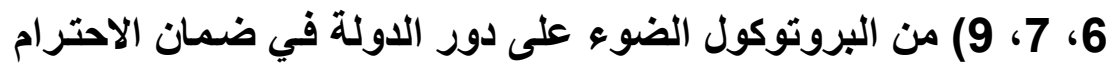

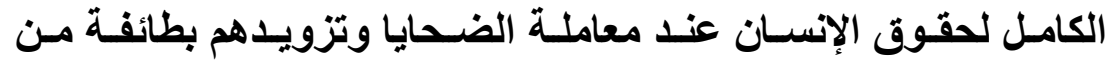

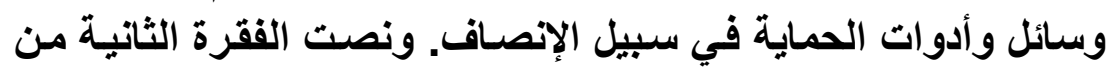

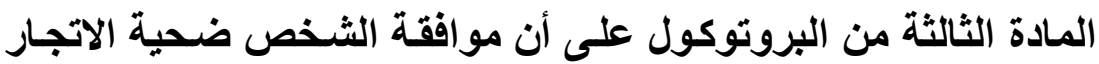

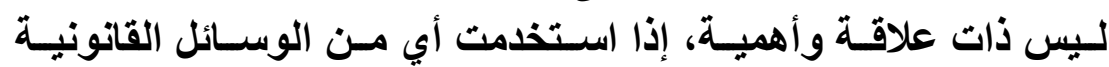

(1) لقد تمت إدانة هذا الفعل واستتكاره أول مرة عام 1815 بالمؤتمر الذي عقد بغينا، ونجد

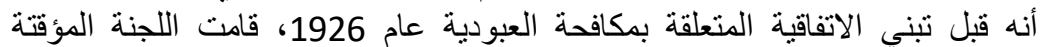

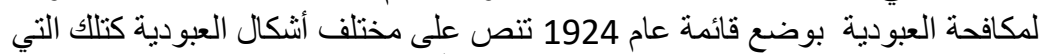

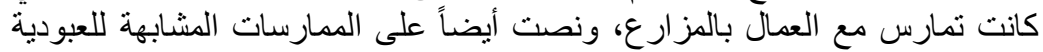

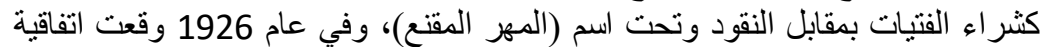

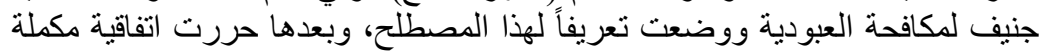

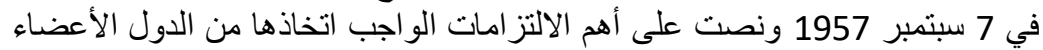

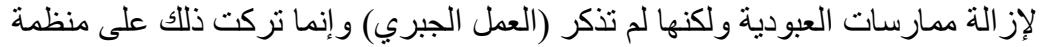

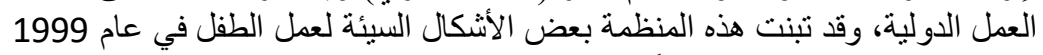

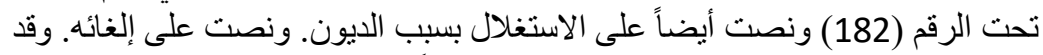

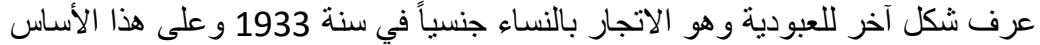

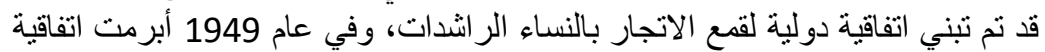

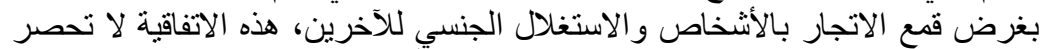

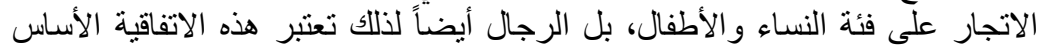
القانوني الذي ارنكزت عليه اتفاق باليرمو بإيطاليا عام الإل 2000. 
المنصـوص عليهـا في القـانون، وبالتـالي لا يمكن استـعمال الموافقـة كجزء من الدفاع الذي يقدمه القائم على الاتجار المتهم.

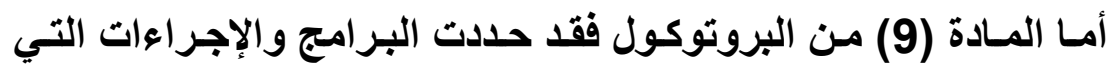

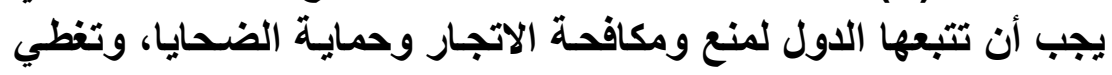

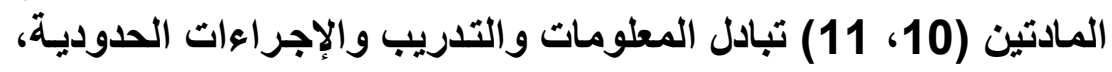

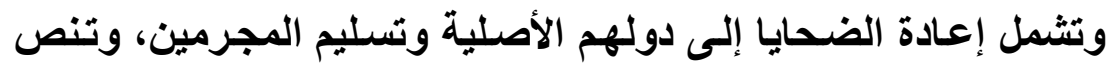

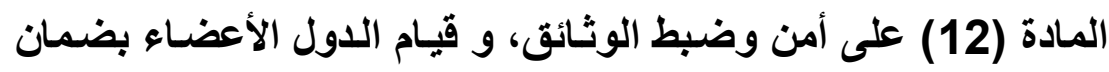

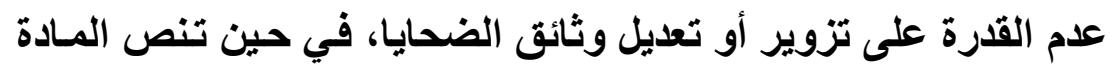

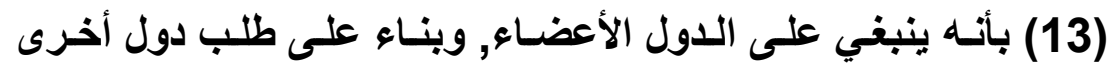

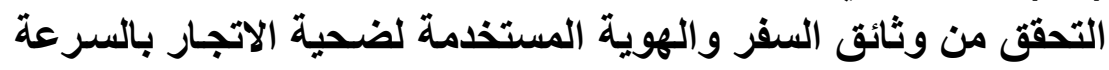

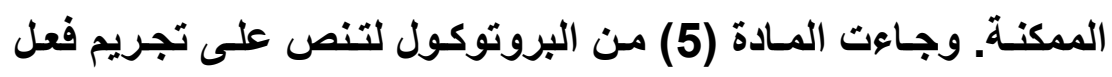

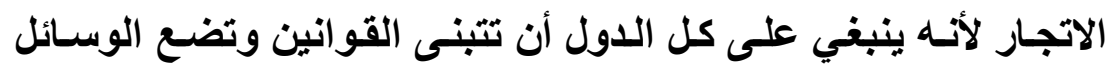

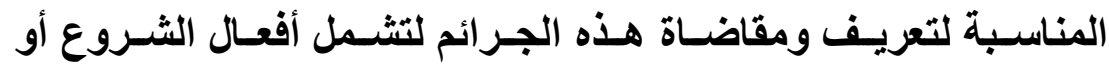
التحريض أو التذخل أو الاشتراضك الجرمي(1).

وإلسى جاتـب هـا البروتوكسول جـاوت اتفاقيـة الأمسم المتحـدة

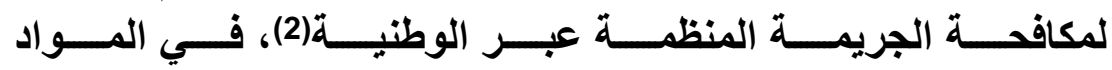

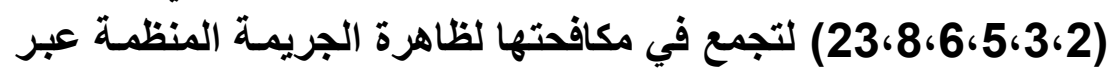

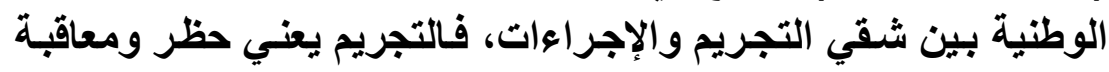

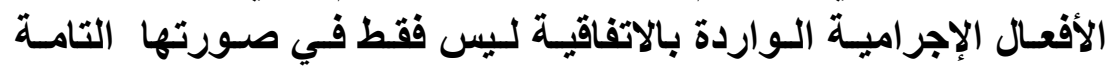

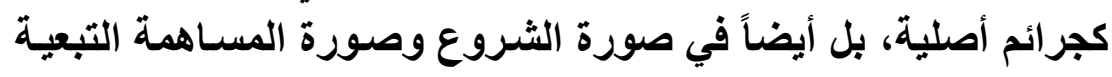

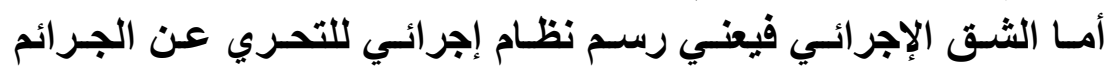

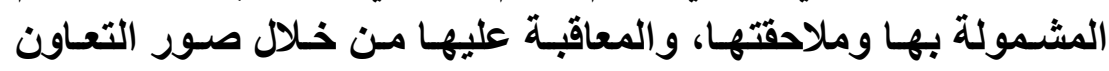
القضائي الدولي في مجالات تكامل الولايـة القضائية وتسليم المجرئي

(1)هنالك بروتوكولان مكملان مع هذا البروتوكول لاتفاقية الأمم المتحدة لمكافحة

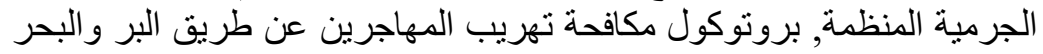

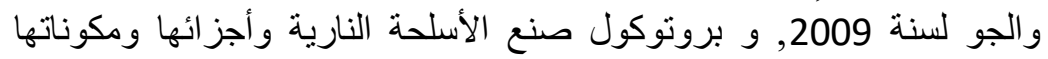

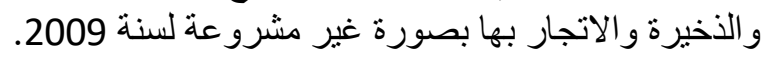

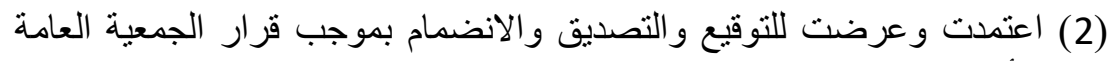

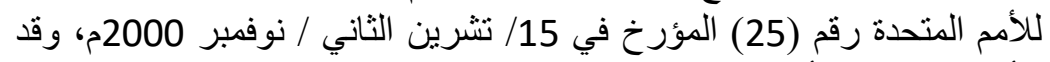
بدأ نفاذها في 29/أيلول/ سبتمبر 2003م. لـون في 
و إنثاء سجل جنائي، ولم تقتصر الاتفاقية على ذلك، بل شملت ملامـح

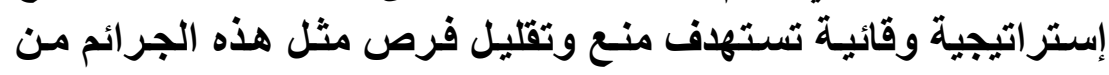
خلال فرض تدابير لمكافحتها قبل وقوعها.

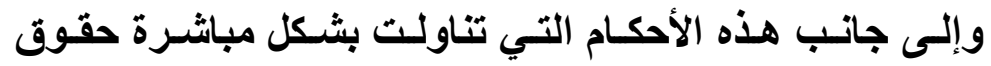

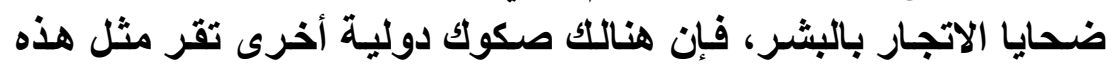

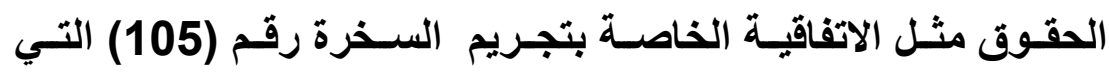

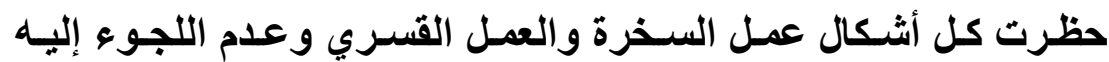

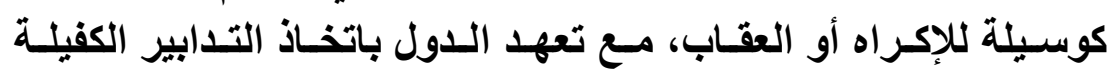
بالإلغاء الفوري الكامل لعمل السخرة والعمل القسري (1). والاتفاقية الدولية للقضاء على جميع أثكال التميز ضد المرأة،

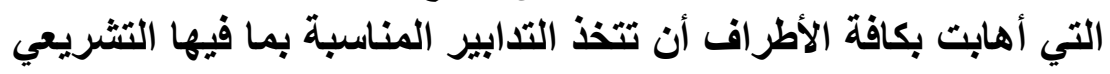

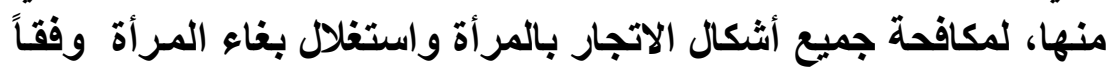

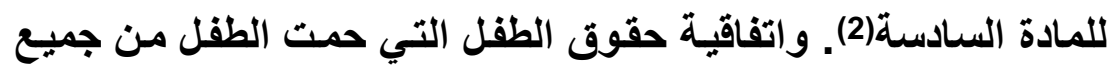

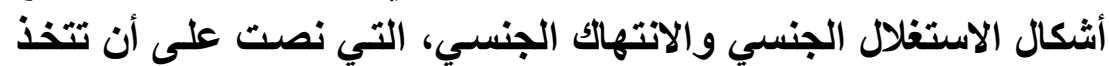

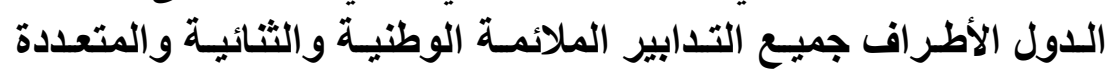

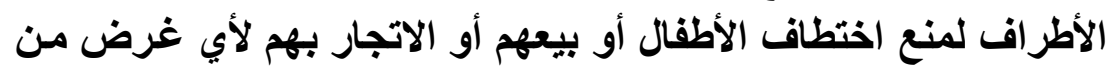

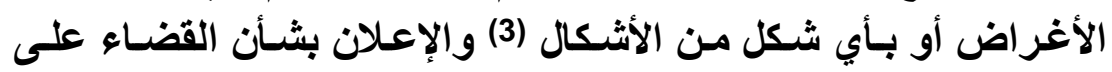

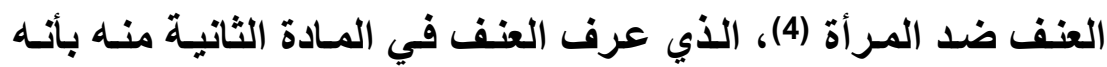

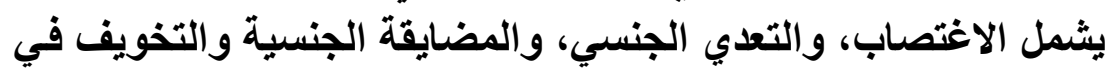

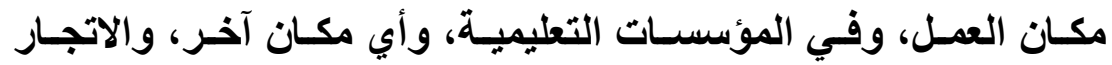

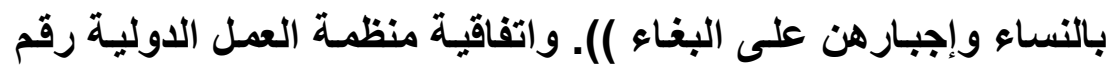
(182) بثـأن القضاء على أسوأ أثكال عمل الأطفال لعام (1999)،

(1) أقرها المؤتمر العام لمنظمة العمل الدولية في (25) يونيو 1957 في دورته

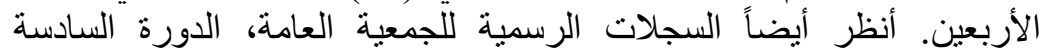

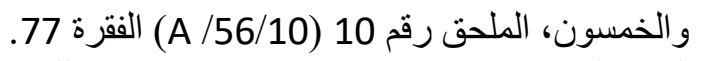

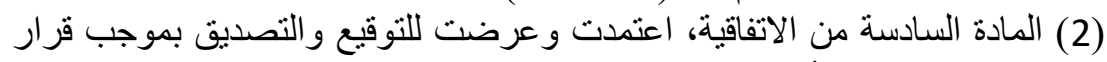

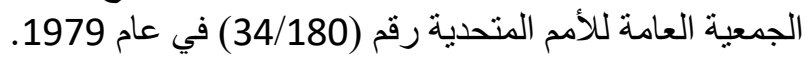

(3) المادتان (34 و 35) من الاتفاقة الإنة.

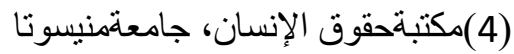

WWW.Hrlibary.ong.ru/arabic.thm. 
حيث حظرت كافة أثنكال الرق، أو الممارسـات الثبيهة بـالرق، كبيع

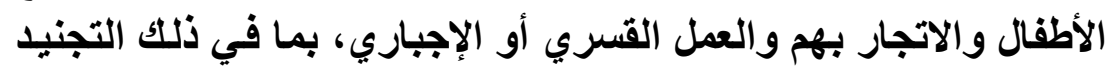

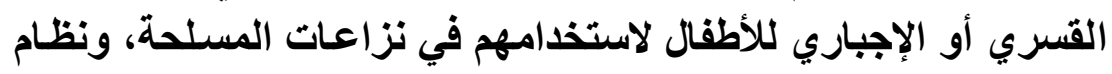

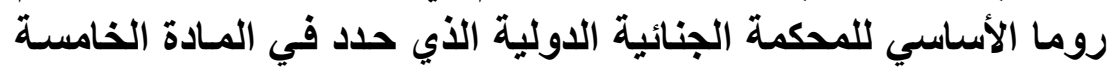

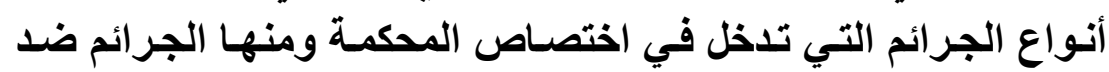

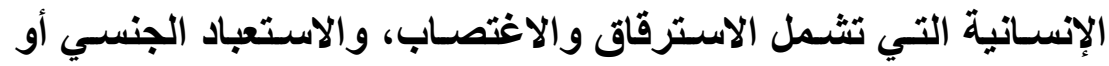

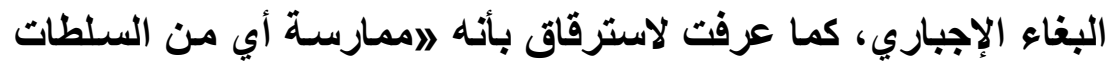

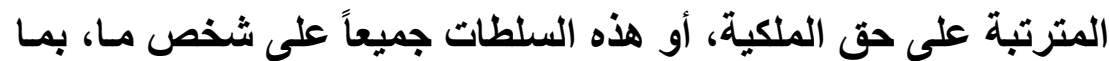

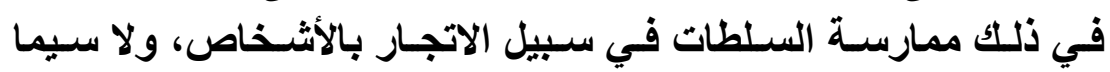

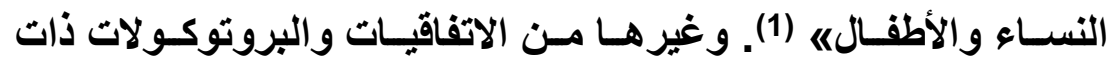

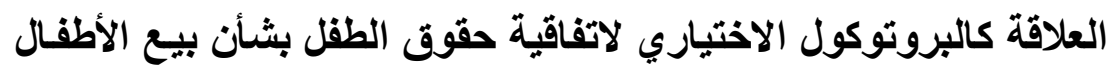

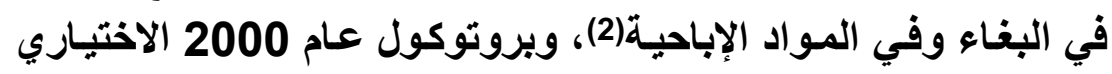

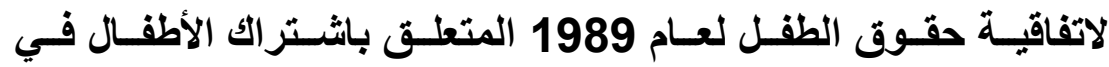

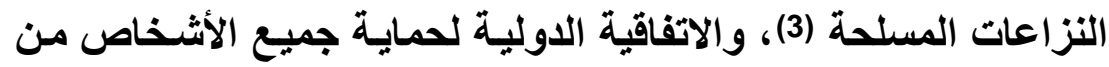

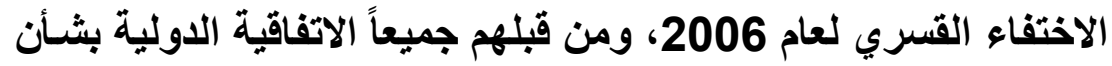

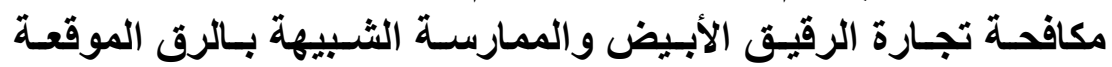

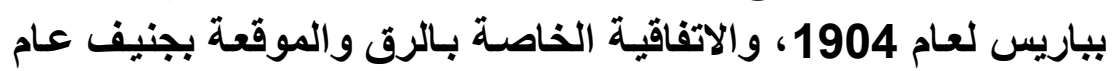

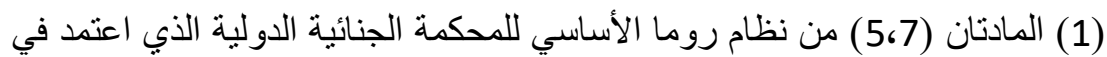

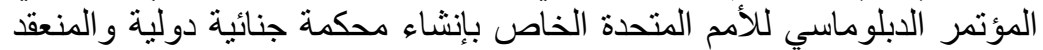

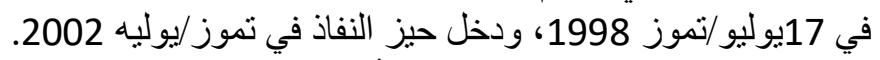

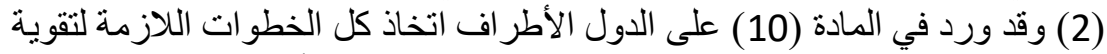

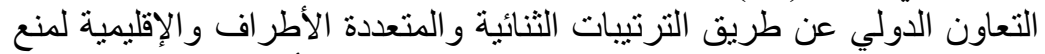

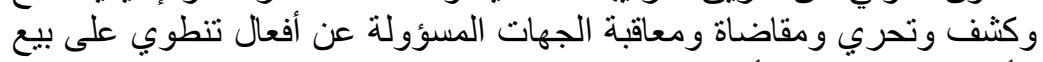

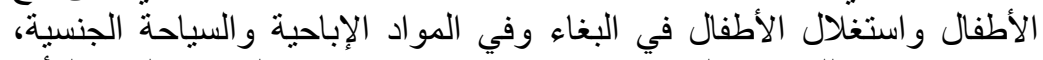

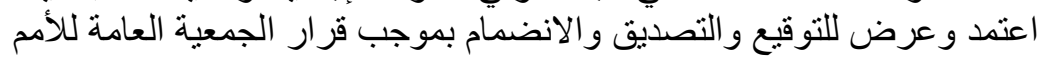

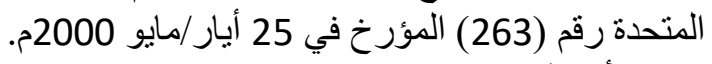
263/A/RES/154 وثيقة الأمم المتحدة رقائ 
1926، واتفاقيـة حظر الاتجـار بالأشـخاص واسـتغلال دعـارة الغير (1) والاتفاقية التكميلية لإبطال الرق وتجارة الآية الرقيق (2).

وفي إطار القانون الدولي فإن مسؤولية الدول في توفير سبل

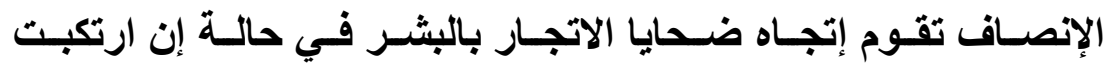

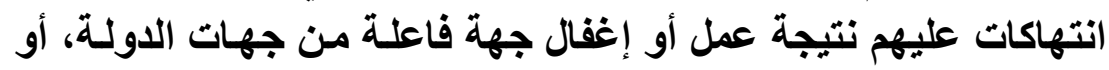

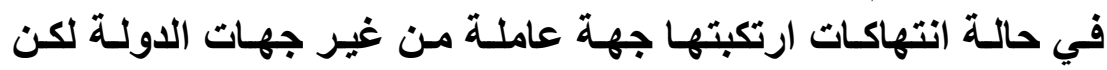

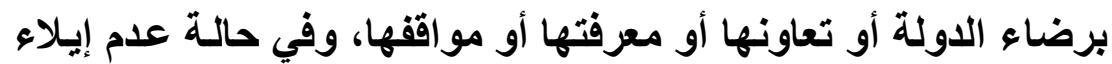

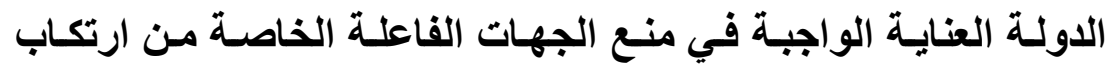

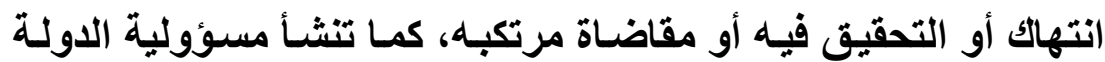

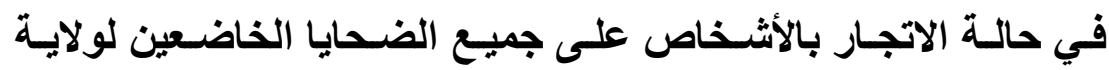

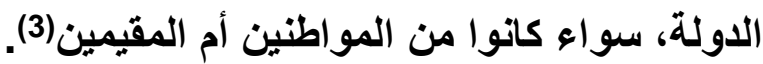

$$
\text { الفرع الثاني }
$$

في مجال التشريعات الإقليمية

أعدت أقاليم مختلفـة أطراً تثريعية ومبـادرات سياسية أكدات

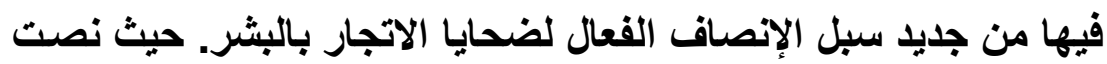

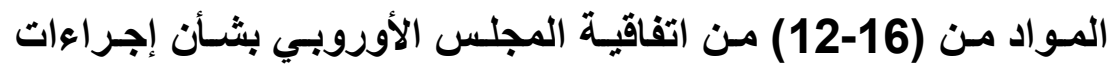

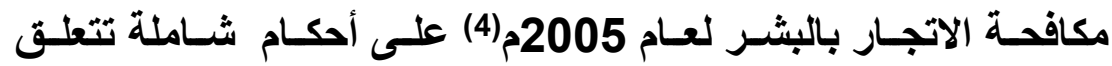

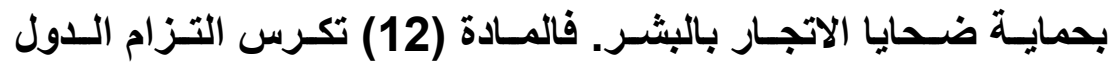

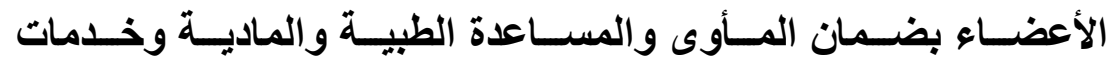

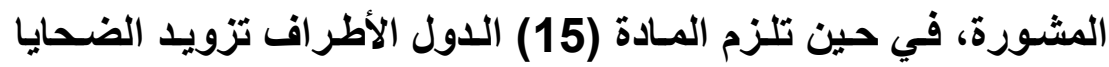
بالمساعدة القانونية المجانية، وضمان التعويض العادل لضحايا الاتجـار

$$
\begin{aligned}
& \text { (1) مجمو عة المعاهدات الدولية في الأمم المتحدة، المجلد (212)، الرقم (2861) }
\end{aligned}
$$

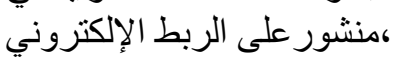
.www.unhehr.ch/htm/menu3/b/f2sc.htm

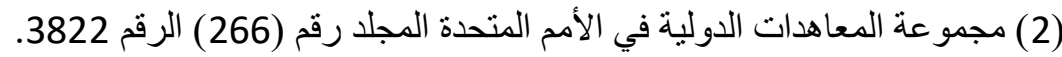

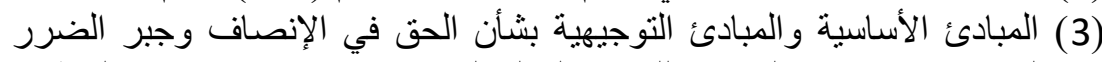

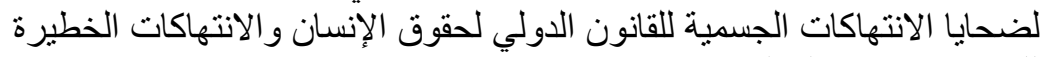

$$
\text { للقانون الإنساني الدولي. }
$$

(4)|تفاقية مجلس أوروبا بشأن مكافحة الاتجار بالبشر، مجموعة معاهدات مجلس الأنس

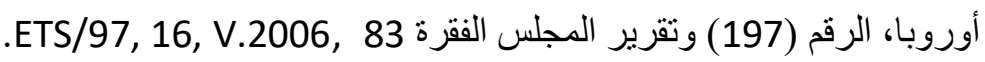




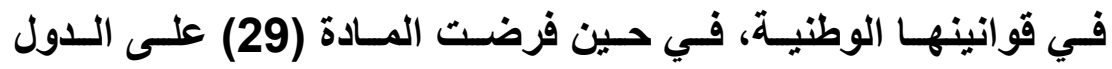

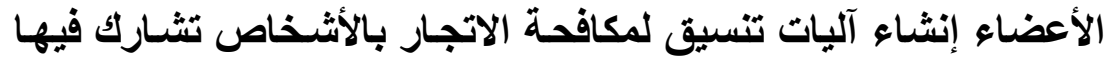

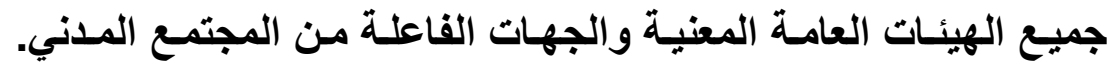

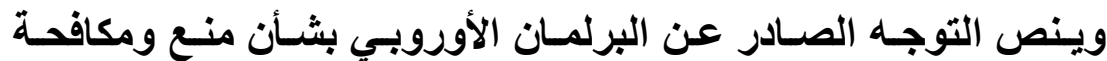

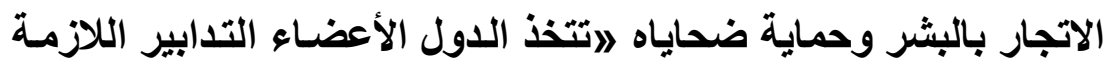

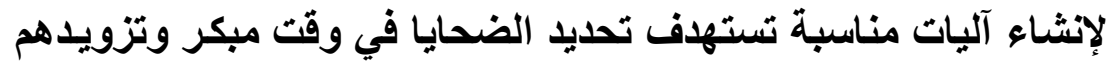

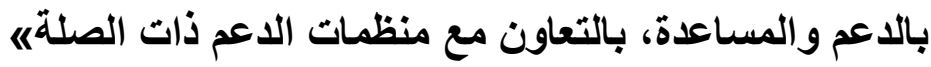

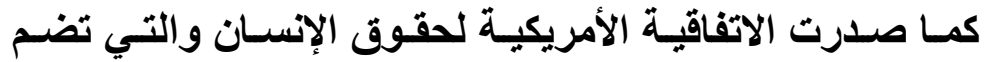

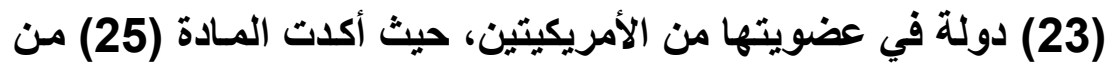

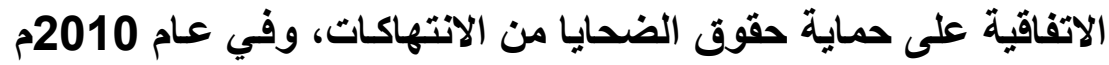

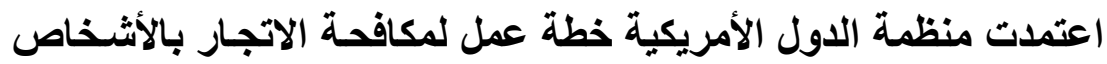

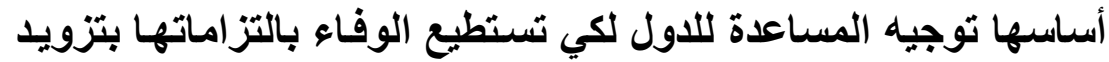

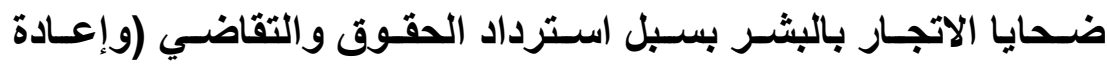
التأهيل) و التعويض وضمانات بالبشر بدم التكرار (1).

وفي قـارة أفريقيـا اعتمــ الاتحساد الأفريقي عـام 2006 خطـة

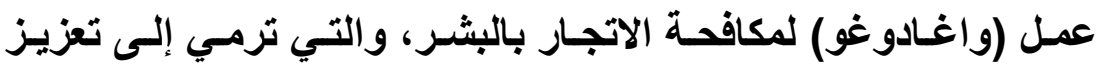

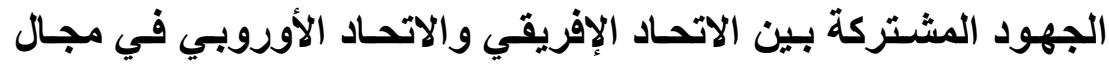

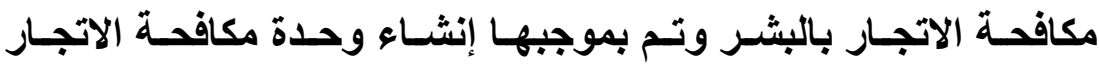

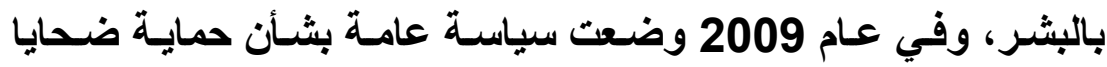
الاتجار بالبشر ومساعدتهم في غرب أفريقيام(20).

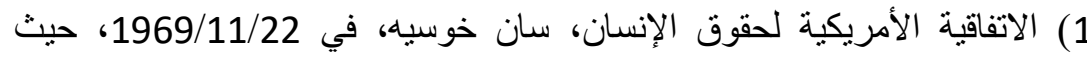

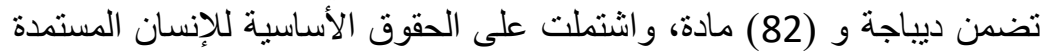

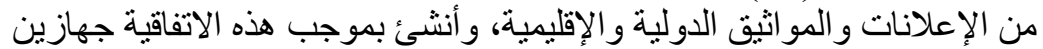

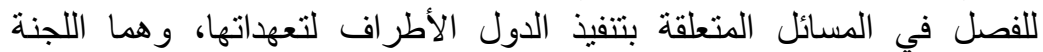
الأمريكية لحقوق الإنسان، والمحكمة الأمريكية لحقوق الإنس الإنسان.

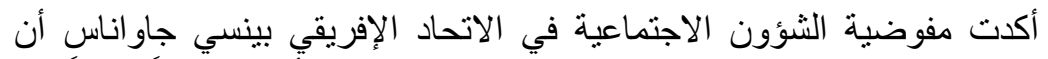

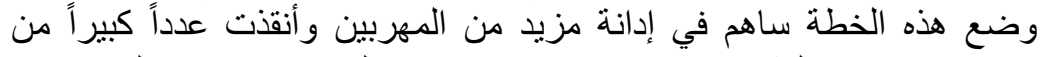

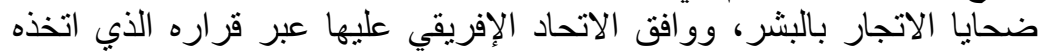
مجلسه التنفيذي في يناير 2009. 
وفي منطقة الثـرق الوسط وشـــال أفريقيـا، تناولت جامعـة

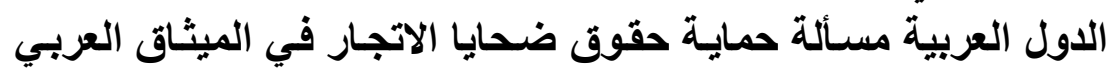

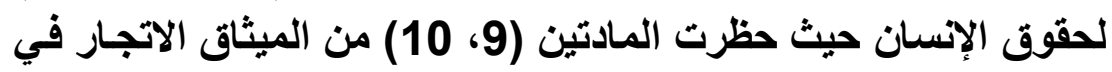

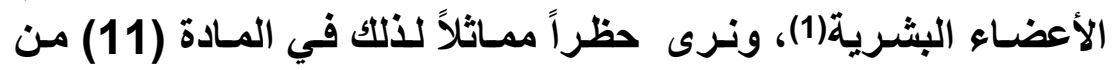

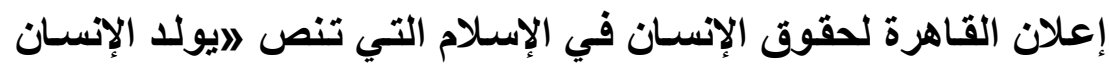

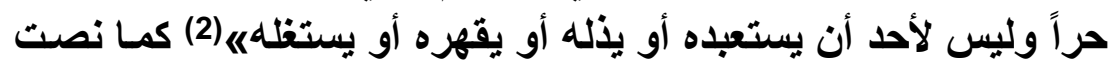

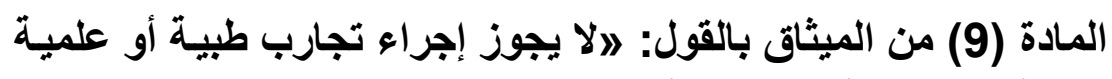

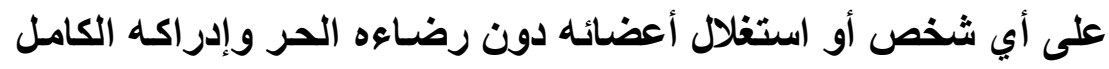

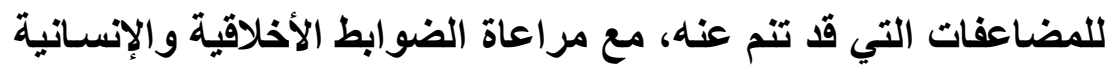

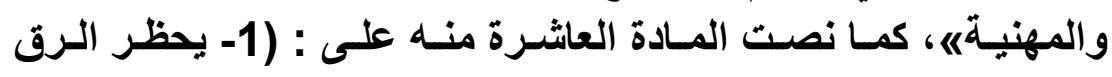

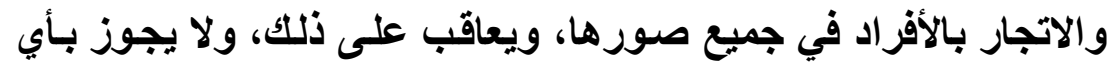

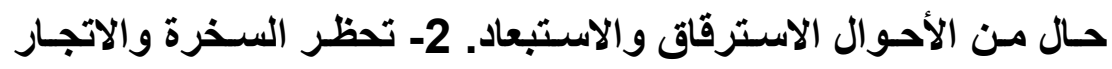

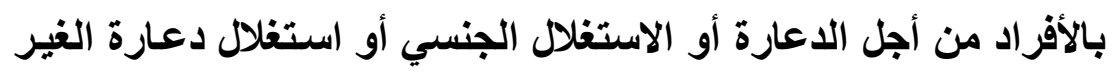

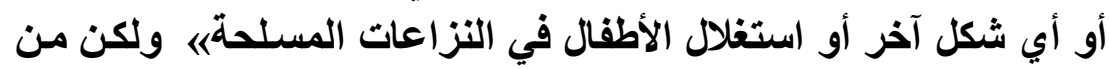
جملة هذه النصوص نلاحظ على الميثاق العربي لحقوق الإنسان مايلي:

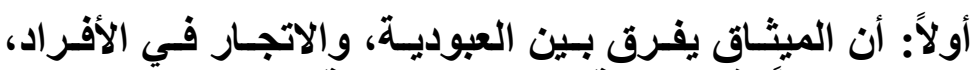

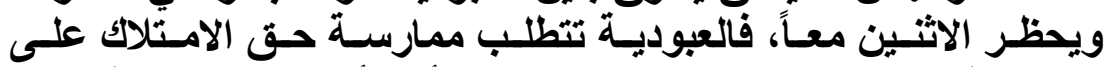

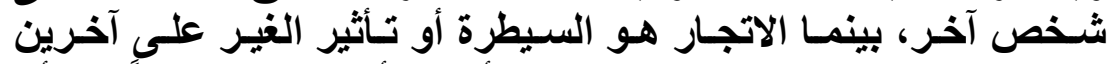

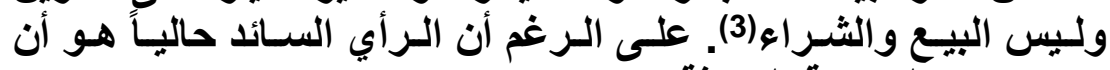
الاتجار هو العبودية الحديثة.

(1) الميثاق العربي لحقوق الإنسان، جامعة الدول العربية، 22 مايو 2004، ودخل حيز النفاذ في 15 مارس العرب الأنيان، 2008.

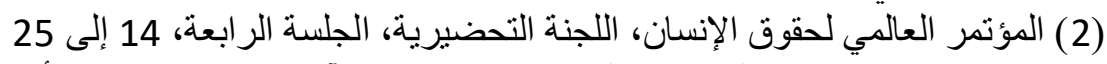

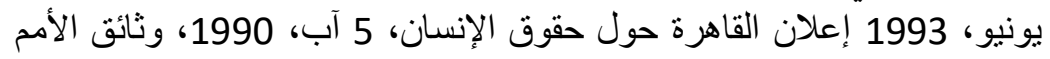

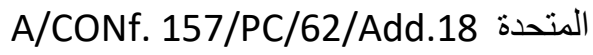

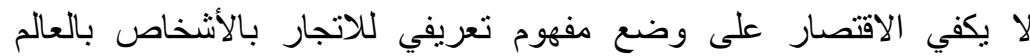

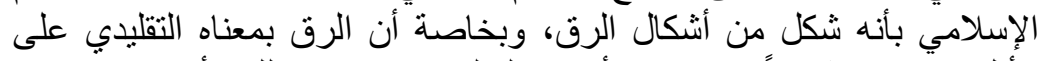

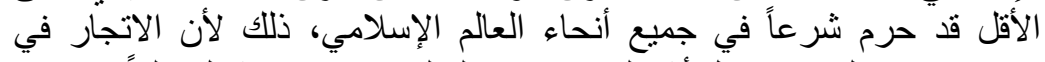

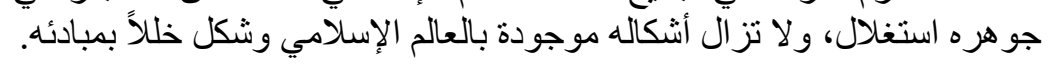




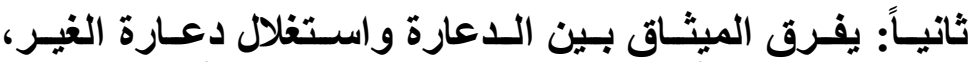

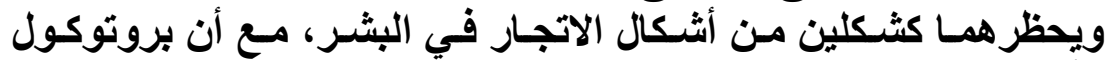

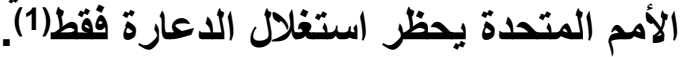

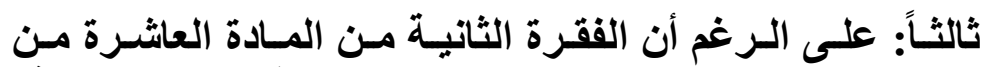

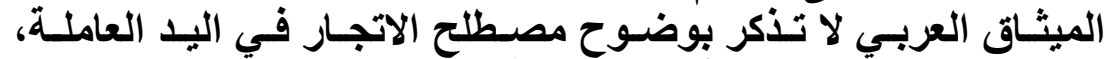

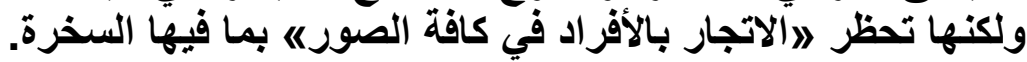
رابعـاً: يركز الميثاق العربـي على أشـكال معينـة مـن الاتجـار

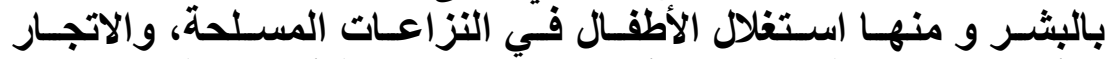

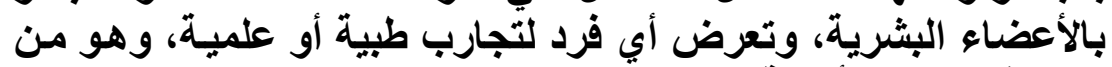

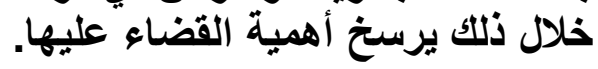

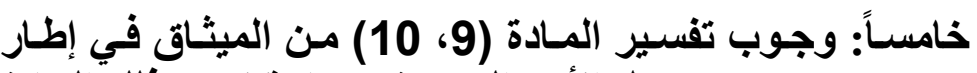

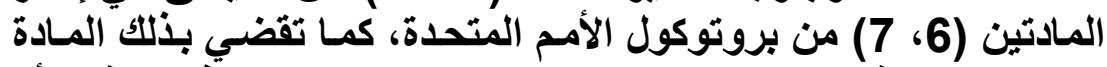

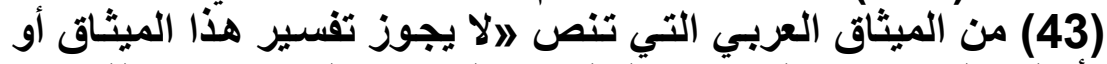

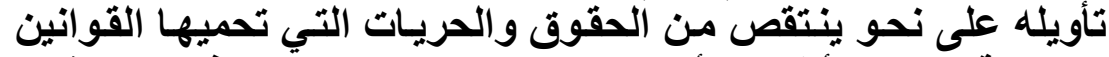

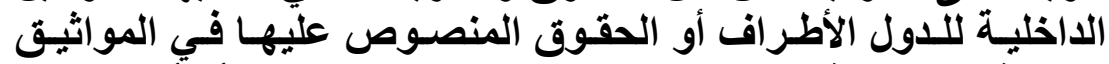

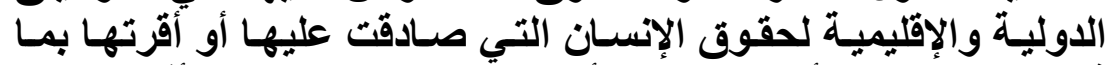

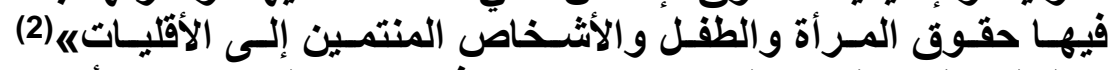

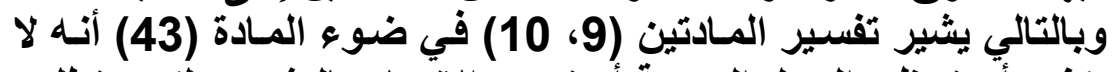

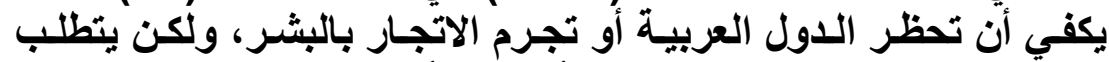

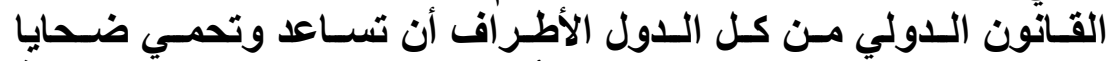

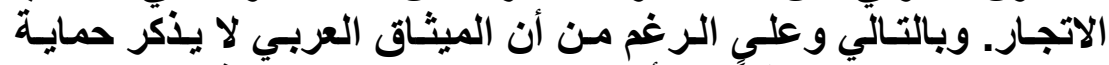

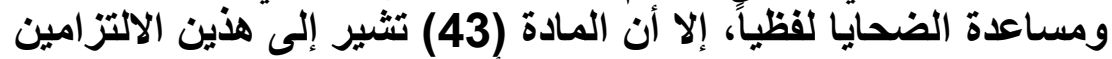
من خلال الجزء الثاني من بروتوكول الأمم المتحدة. القرع الثالث في مجال التشريعات الوطنية

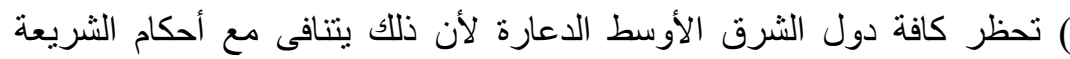

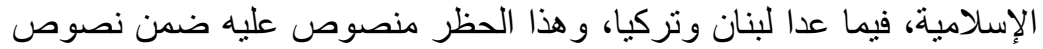
قانون العقوبات حيث يجعل من ممارسة الدعارة والأنشطة المتعلقة بها جريمة معاقب عليها قانوناً.

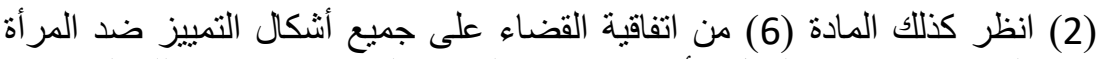

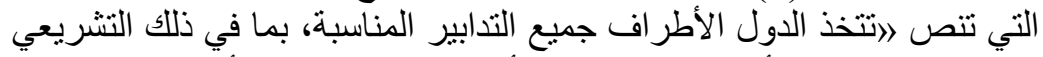
منها، لمكافحة جميع أثنكال الاتجار بالمر أة واستغلال بغاء المر أثة) 
لا يمكن وضسع سياسـة شـاملة مانعـة لحمايـة ضحية الاتجـار

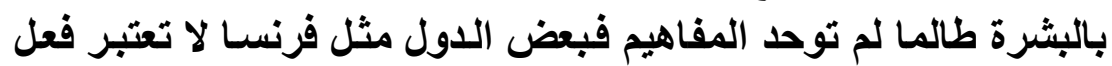

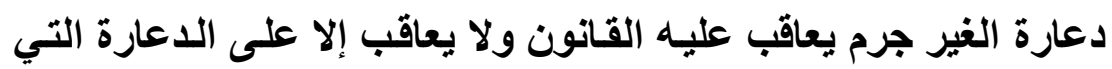

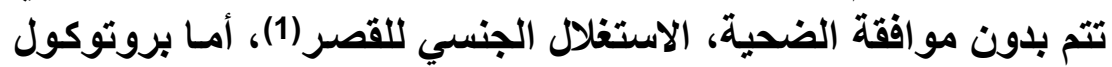

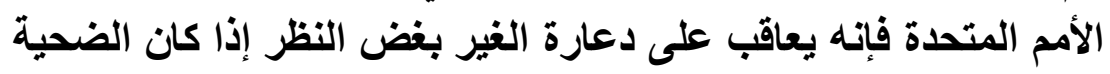

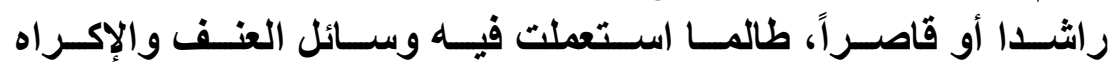

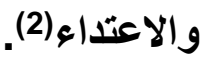

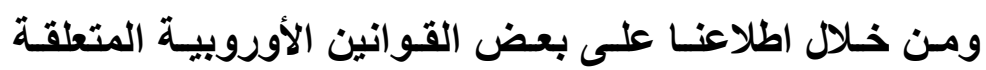

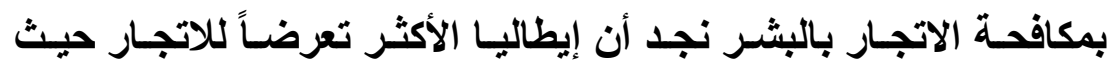

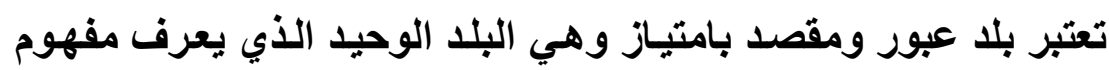

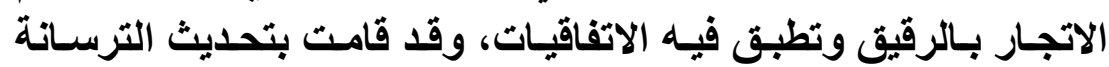

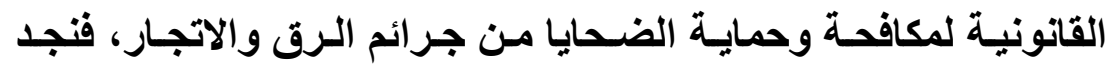

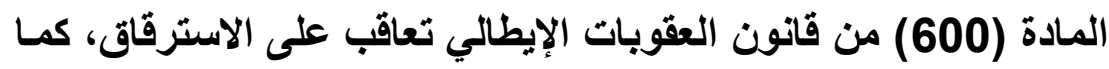

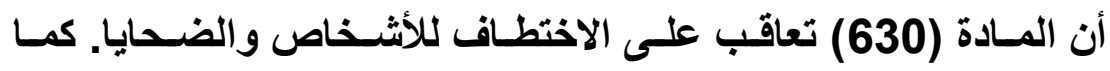

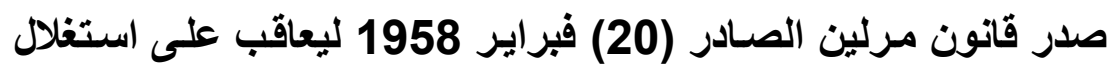
دعارة الغير وعلى أساس المادة (600) عقوبات.

ويلاحظ على القانون الإيطالي بأنه طبق سياسات مبتكرة تتمثل

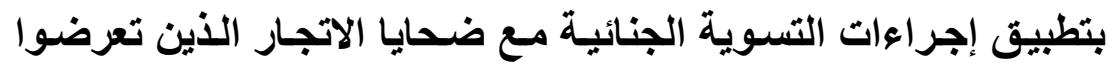

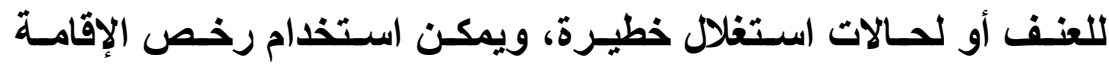

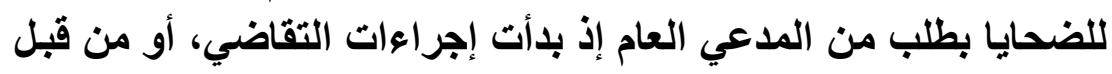

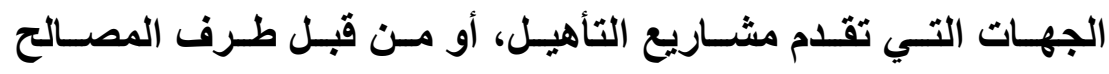

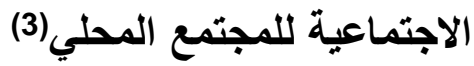

اجتمعت رئاسة الاتحاد الأوروبي في 26 إبريل 1997 على مستوى مؤتمر الإني

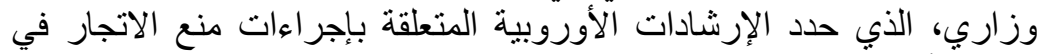

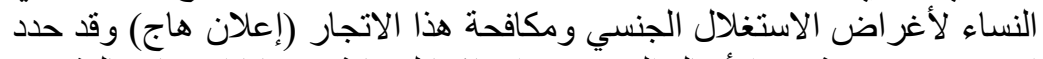

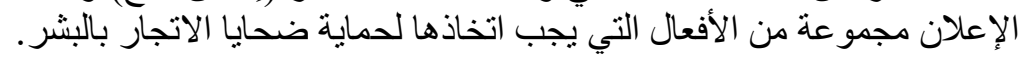

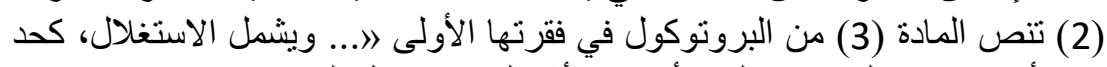

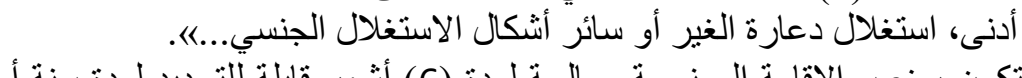

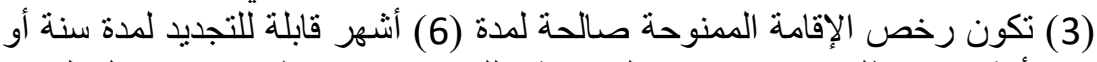

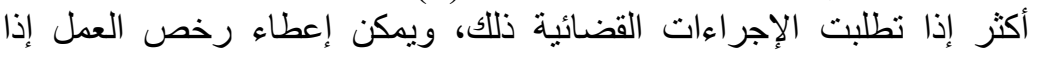




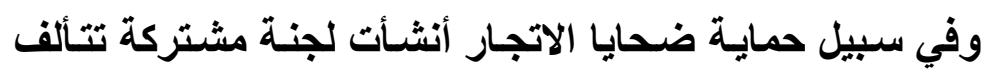

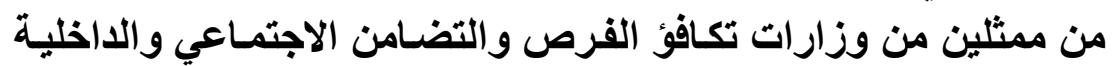
والعل لتطبيق إجراءات حماية الضحايا (1).

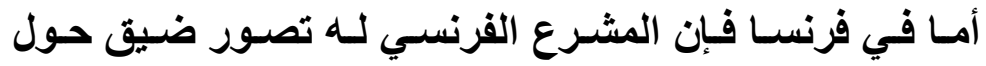

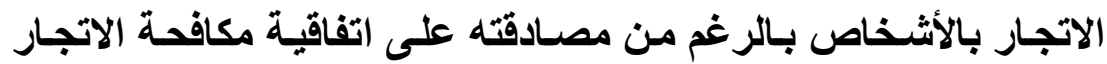

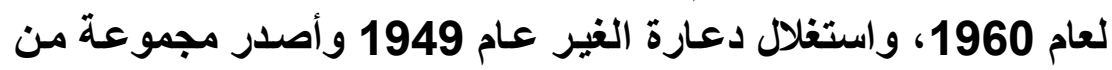

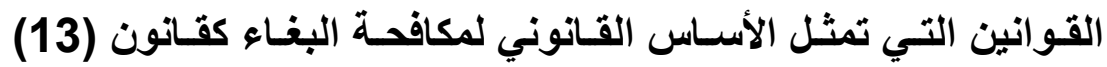

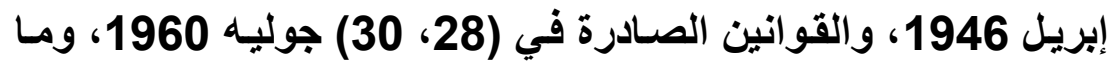

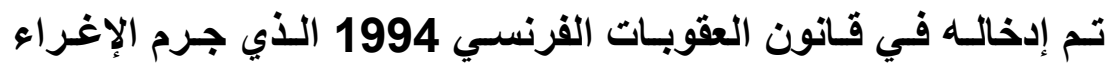
الإيجابي الأي يعاقب على الوساطة في البغاء وفقاً للمادة (7/1/225)

التحقق الأجنبي بعمل ما، ويمكن منح رخص الإقامة للأجنبي الضحية الذي سجل نفسه في مؤسسة تعليمة. (1) كما تقرر الجمعيات الأهلية عدة برامج لفية لحماية ومساعدة الضحايا المدمجين

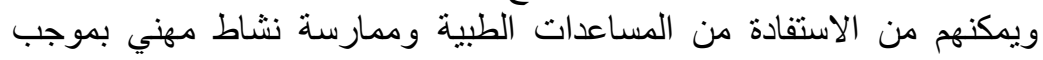

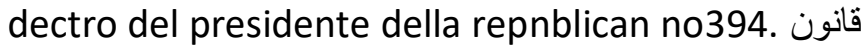


من قانون العقوبات(1) كما حظرت المـادة (1/4/225) كل نثـاط مهني

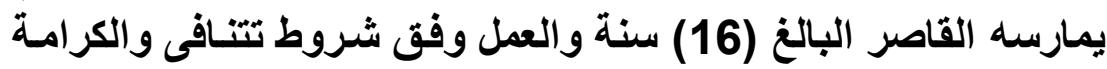

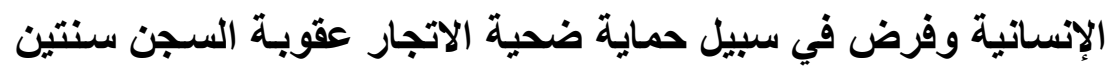

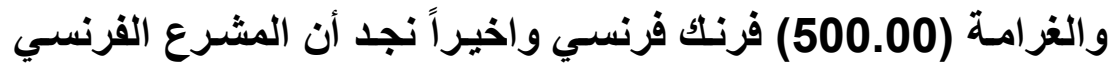

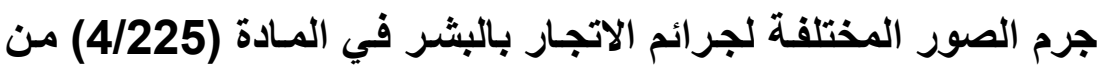

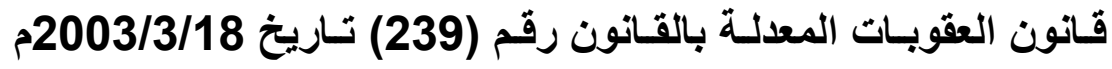

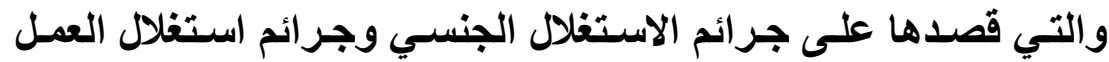

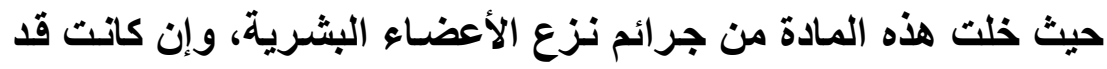

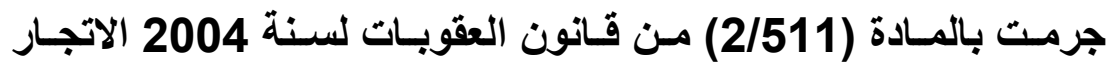

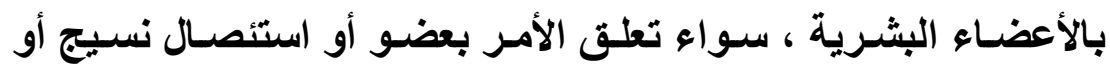

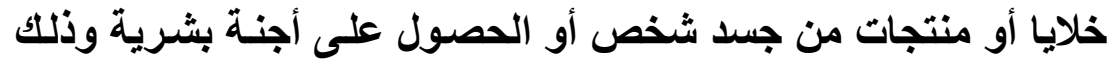

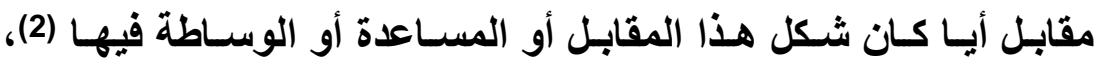

$$
\text { (1) تتص المادة (225) من قانون العقوبات الفرنسي على المعاقبة على البغاء : البعاء }
$$

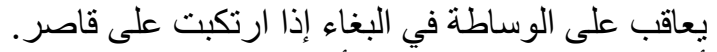

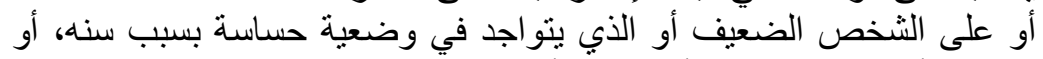
مرضه، أو عجزه الجسدي أو النفسي أو حالة التحمل.

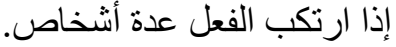
وكذلك المحرض على فعل الاستغلال الجنسي سواء خارج أقاليم الجمهورية أو ألجاء عند وصوله إقليم الجمهورية.

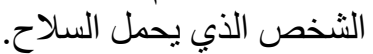
الثخص الذي يستعمل التهديد، و العنف و المناورات الاحتيالية أو المخادعة.

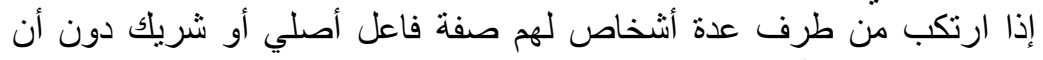
يكونو ا جماعة منظمة.

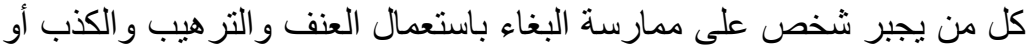
إساءة استعمال مركز التفوق أو الضرر أو ضعف الضحية باليعال يعاقب بسنتين إلى 4

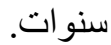

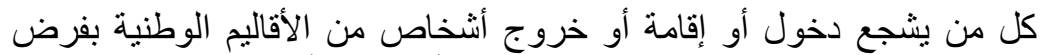

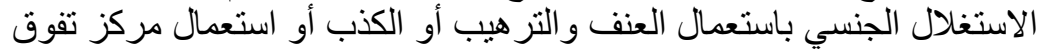

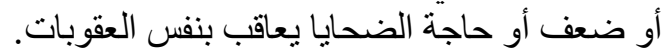

(2) Art 511-2 Le fait d' obtenir d'une personne l'un de ses organs contre un paiement quelle qu'en soit la forme, est puni de sept ans d'emprisonnement et de 100000 euros d'amend, Est puni des meme peines, le fait d'apporter son entremise pour favoriser l'obtention d'un organs contre le paiement de celui- ci, ou de céder á titre onéreux un tel organ du corps d'autrui. Les mémes peines sont 


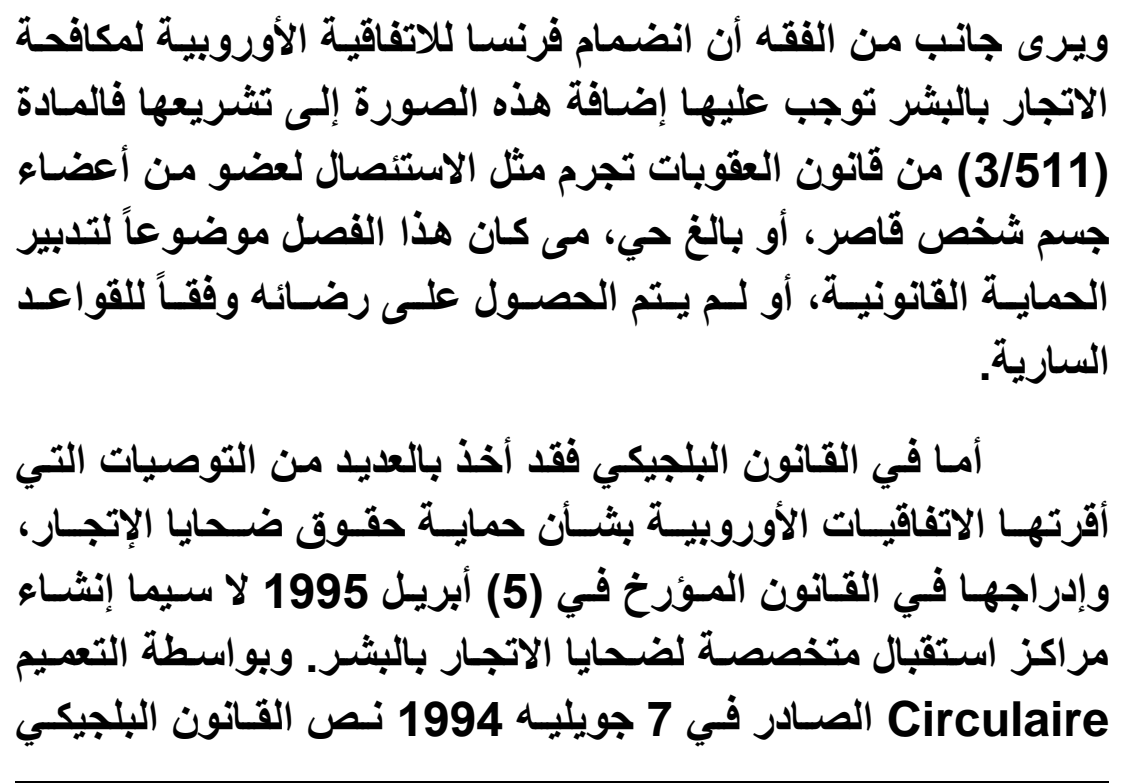

applicable dans le cas ou l'organe obtenu dans les conditions prévues au premier alinéa provient d'un pays étranger.

Art 511-4: Le fait d'obtenir d'une personne le prélévement de tissus, de cellules ou de produits de son corps contre un paiement, quelle qu'en soit la forme, est puni de cinq ans d'emprisonnement et de 75000 euros d'amende. Est puni des mémes peines le fait d'apporter son entremise pour favoriser l'obtention de tissus, de cellules ou de produits humains contre un paiement, quelle qu'en soit la forme, ou de céder á titre onéreux des tissus, des cellules ou des produits du corps d'autrui.

Art 511-9 Le fait d, obtenit des gametes contre un paiemen, quelle quen soit laforme at ex caption du paiement des prestaition assures patles etablissement, effectuant la prepar athion et la con servation de co gametes, est puni de cinq ans d.emptisonnement et de 75000 euros d,amende, Est puni des me, mes peins le fait d,apporter son entremise pour favor isor I, obten tion de gamets contre unpaiement quelle quen soit la forme oude remettre ades tiers a titre onereux gametes provenant de dons

Art 211-15 le fait d'obtenir des embryons humains contre un paiement, quelle qu'en soit la forme, est puni de sept ans d'emprosonnement et de 10000 euros d'amendeEst puni des mémes peines le fait d'apporter son entremise pour favoriser l'obtention d'embryons humains contre un paiement, quelle qu'en soit la forme, ou de remettre á des tiers, á titre onéreux, des embryous humains. 


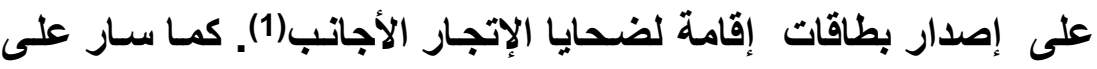

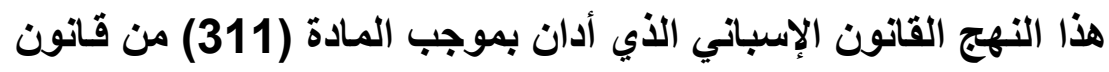

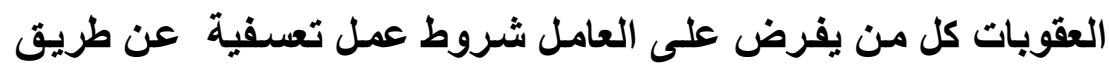

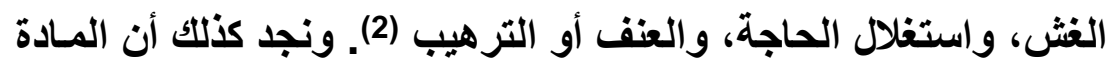

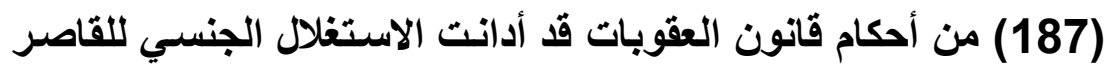
ضحية الاتجار، واستعمال القوة عند استغلال الثخص الجنسي التونس للقاصر

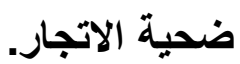

وفي سـتة عشـر أصــر الكـونجرس الأمريكي قـانون حمايـة

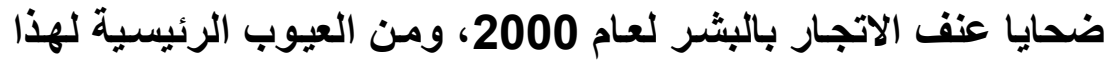

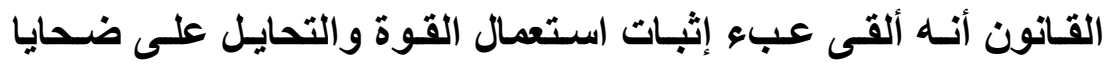

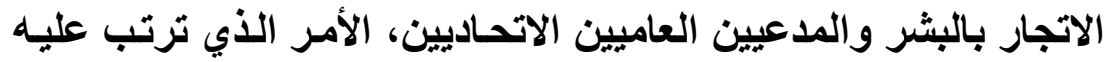

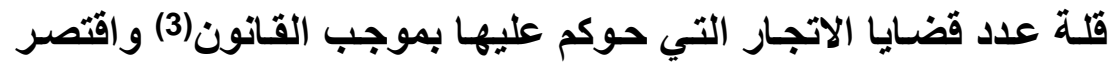

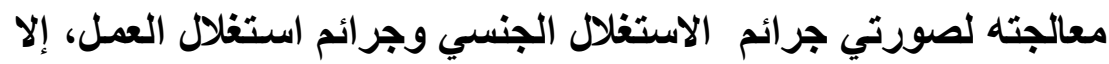

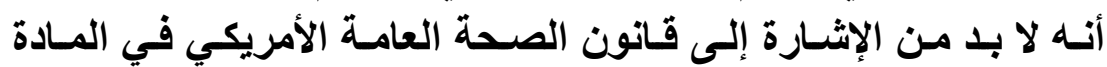

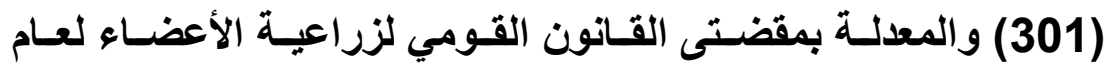

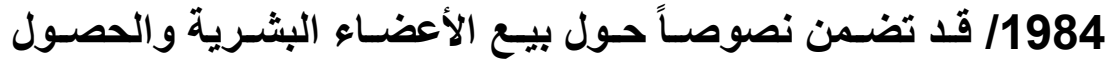

عليها) (4)

$$
\text { ومنظمة (Payoke) من بين المراكز التي تم إنشاءها مركز (Pag-AsA) بيروكسل في عام 1995م }
$$

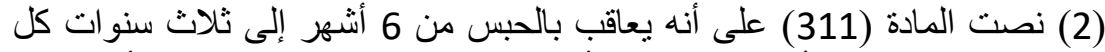

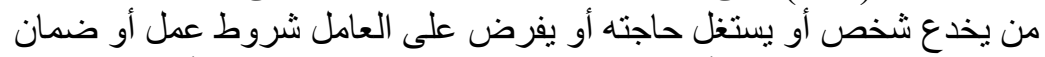

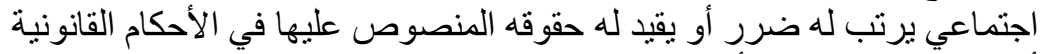
أو الاتفاقيات الجماعية أو العقود الفردية.

(3) لم تتجاوز القضايا التي حوكم بهاعة بموجب هذان القانة القانون من عام (2008-2004) / 137 قضية . لتخارز

(4)Abrief text of subsec (a) sec (301) public health service Act title (1) the national organ transplant act 1984 it un lawful for any person to knowingly acquire receive or other wise transfer any human organ for valuable consideration for use in human trans plantation if the transfer affects interstate commerce.. 


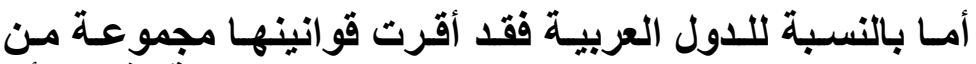

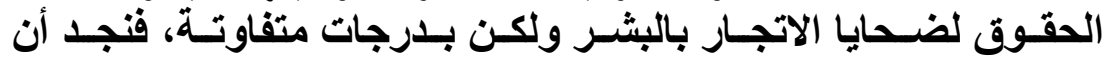

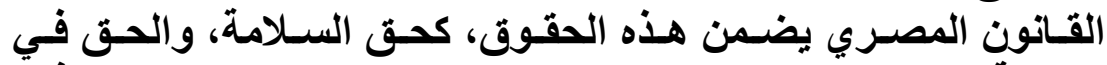

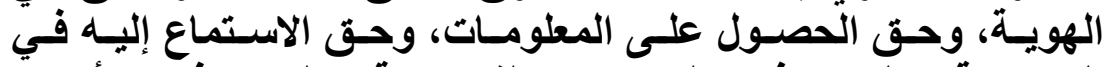

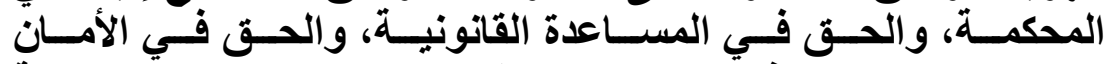

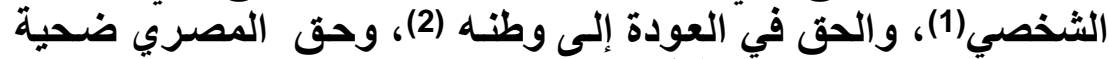

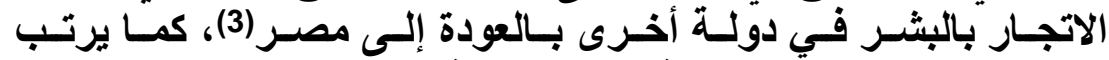

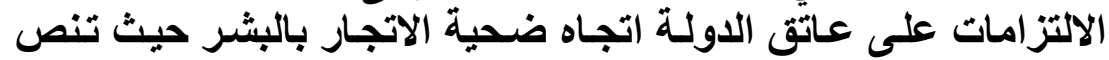

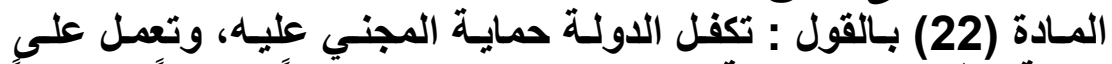

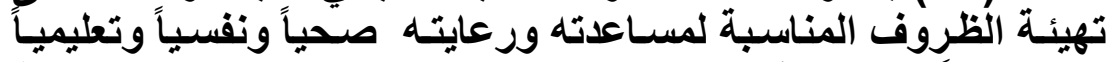

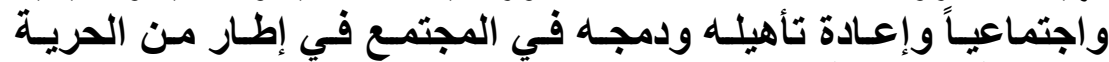

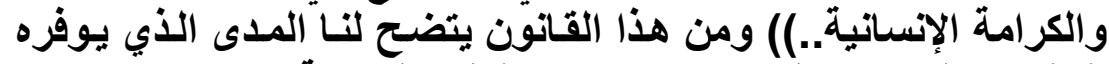

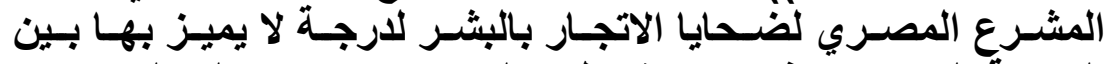

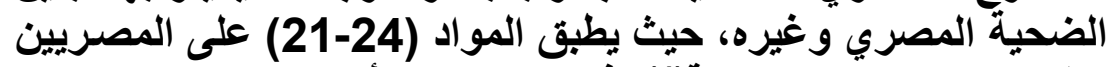

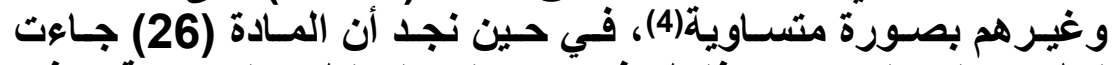

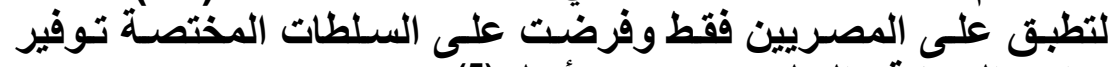
برامج الرعاية والتعليم وتدريب وتأهيل (5).

في حين فرض قـانون مكافــة الاتجـار بالأشـخاص البحرينـي

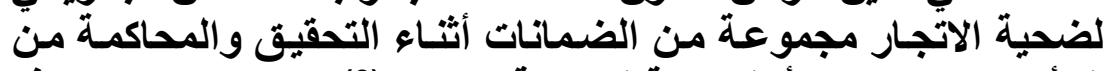

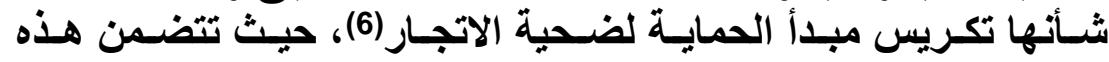

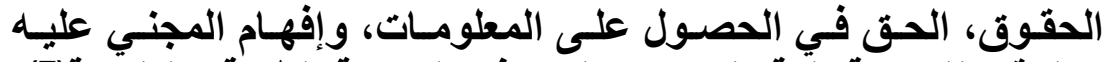

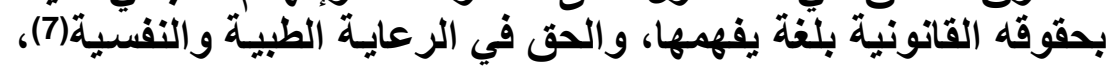

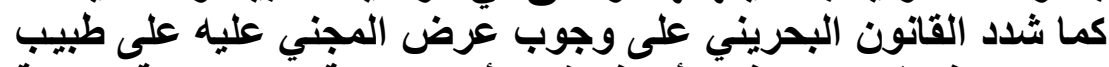

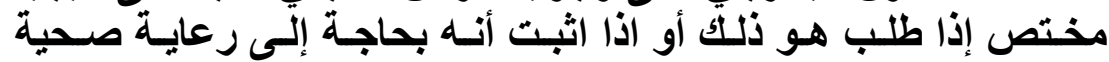

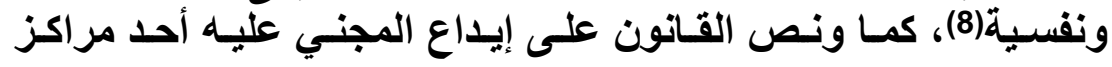

$$
\begin{aligned}
& \text { (1) المادة (23) من قانون مكانة الاتجار بالبشر رقم (64) لسنة 2010م المصري. }
\end{aligned}
$$

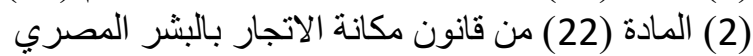

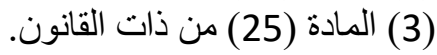

$$
\begin{aligned}
& \text { (4) أنظر المواد (25) (21-24) من قانون رقات (64) لسنة } 2010 \text { بشأن مكافحة الاتجار }
\end{aligned}
$$

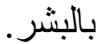

$$
\begin{aligned}
& \text { (5) أنظر المادة (26) من القانون ذاته } \\
& \text { (6) أنظر المادة (5) من قانون بشأن مكافحة الاتجار بالأشخاص البحريني رقم (1) منانه }
\end{aligned}
$$

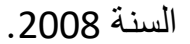

$$
\begin{aligned}
& \text { (7) (7) أنظر المادة (3/1/5) من ذات القانون. } \\
& \text { (8) (3/5) (3/5) من ذات القانون. }
\end{aligned}
$$




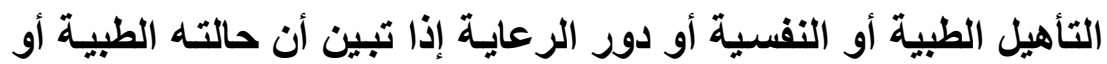
النفسية أو العمرية تستدعي ذلتكية النفيل.

وبـالرجوع إلى أحكام قـانون مكافحة الاتجـار بالبشـر الأردنسي

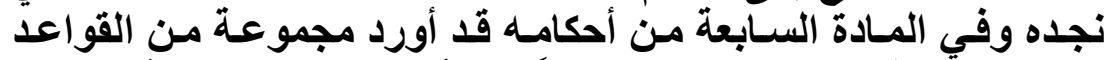

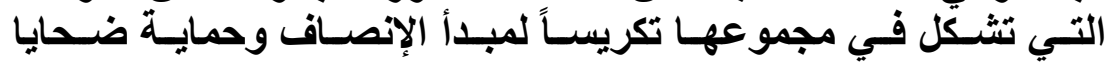

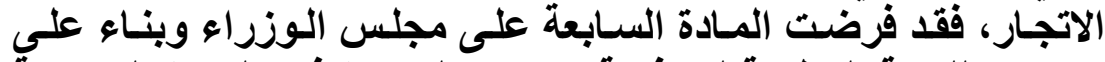

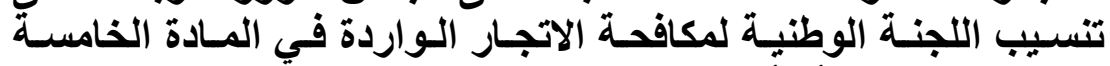

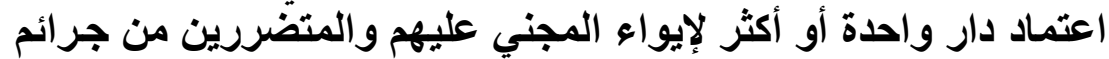

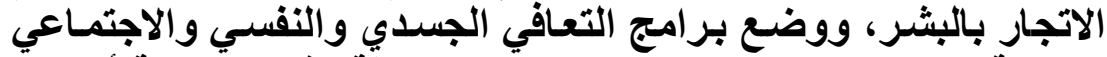

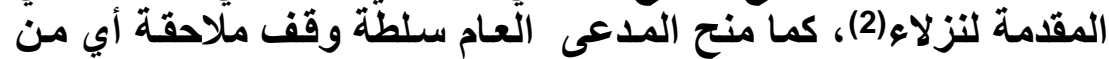

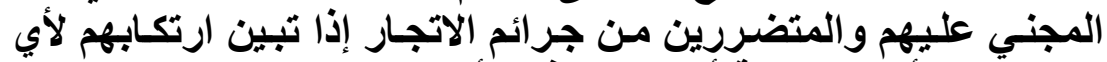

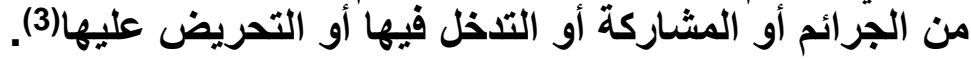
كما نص نظام الاتجار بالبشر السعودي على جملة من الحقة العقوق

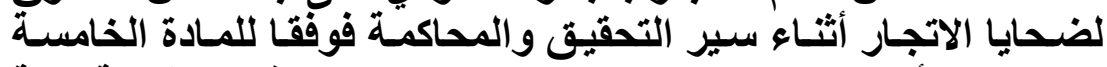

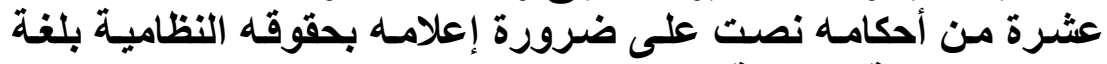

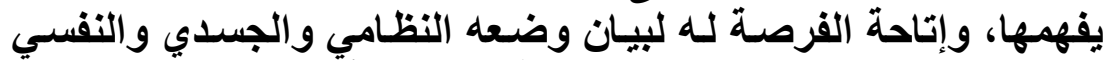

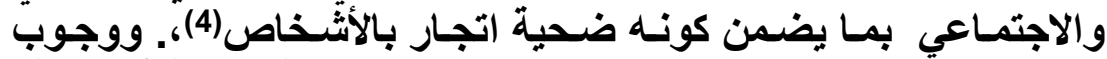

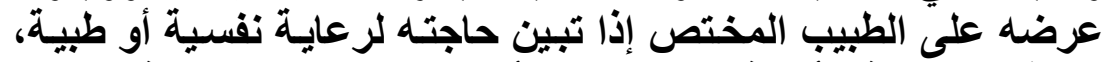

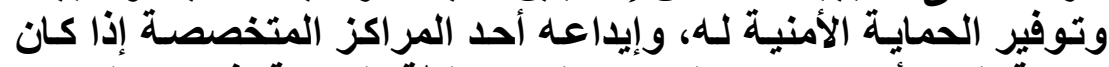

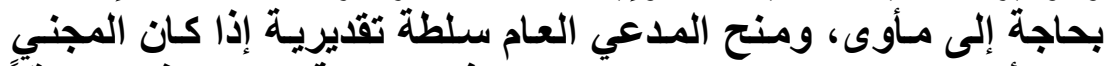

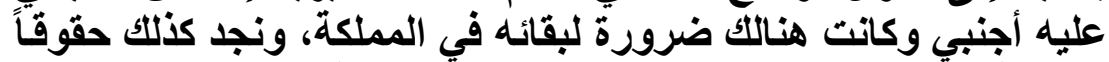

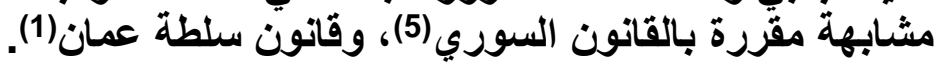

$$
\text { (1) (1) أنظر المادة (4/5) من ذات القانون. }
$$

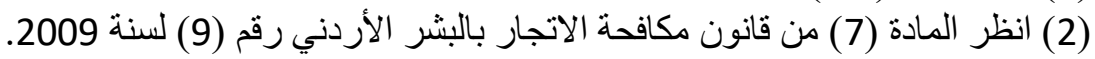

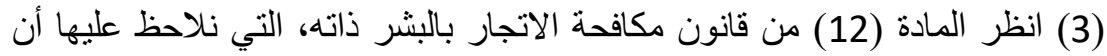

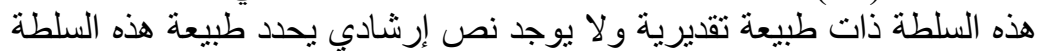

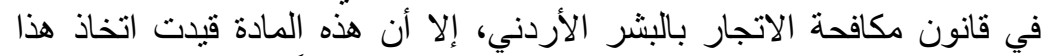

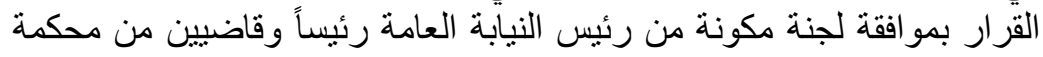

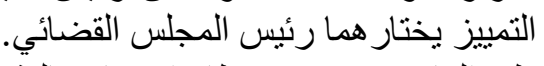
(4)انظر المادة (15) من نظام الاتجار بالبشر السعودي الصنادر بالمرسوم الملكي

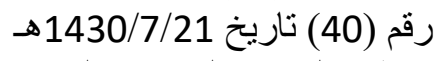

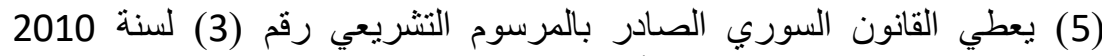

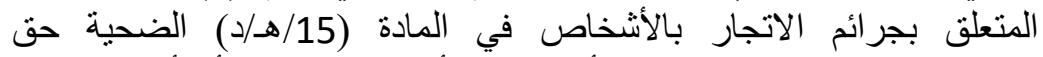

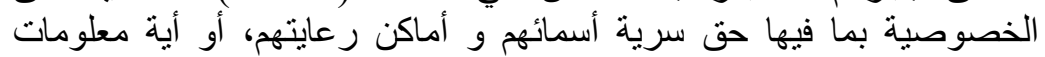
أخرى قد تكثف هويتهم، ومخاطبهم بلغة مفهومه لهم. 
(1) نصت المادة (5) من المرسوم السلطاني رقم (126) لسنة 2008 الصادر بتاريخ

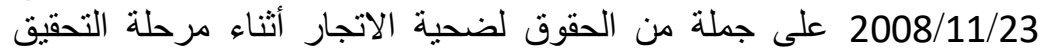

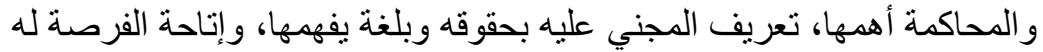
لبيان وضعه القانون والجسدي والنفسي والنيفي والاجتماعي، وتوفير الحماية اللازمة له، و البقاء في السلطنة إذا اقتضى ذلك التحقيق و المحاكمة. 


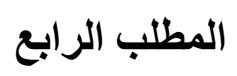

المؤشرات الدالة على ضحية الاتجار بالبشر

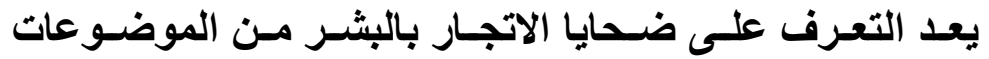

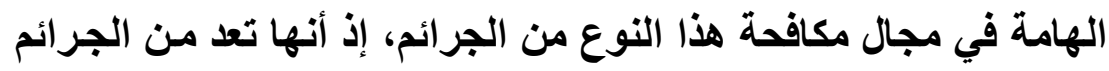

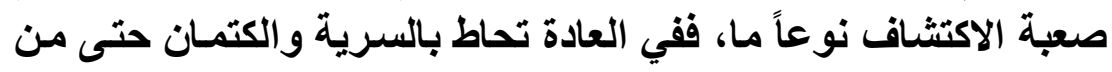

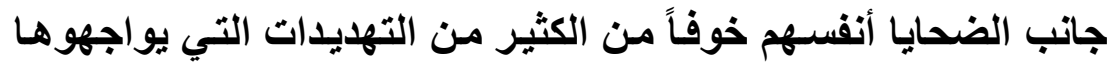

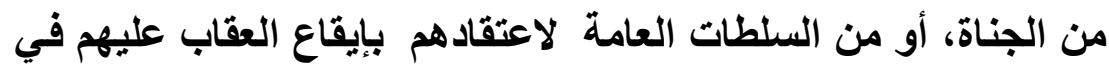

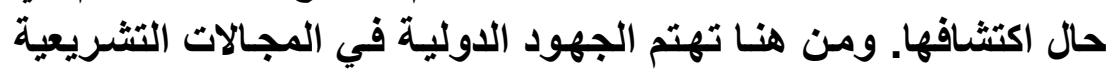

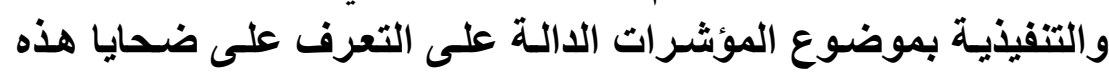
الجرائم لتسهيل اكتشافها والمعاقبة عليها.

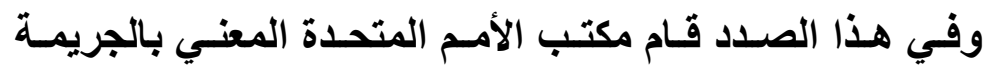

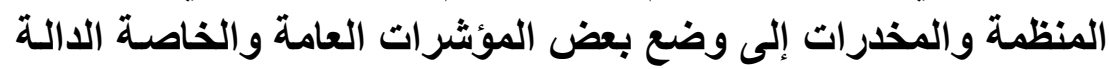

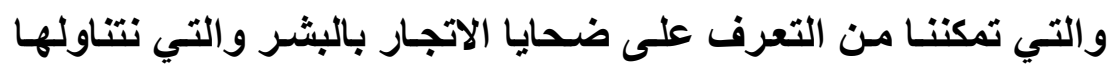
كالآتي:

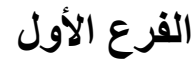

المؤشرات العامة الدالة على ضحية الاتجار بالبشر

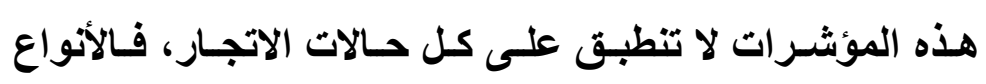

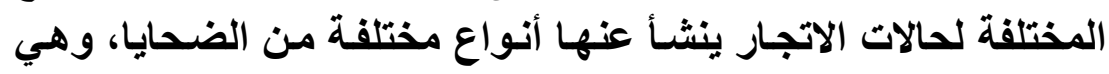

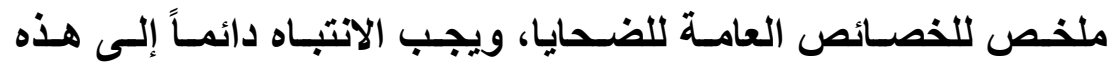

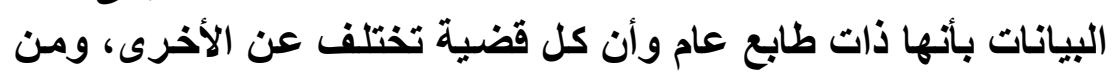

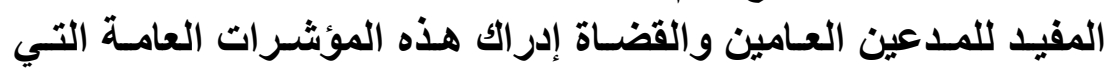
تشمل :

أولاًا العمـر: يعتمــ عمـر الضـحية على طبيعة عمليـة الاتجـار

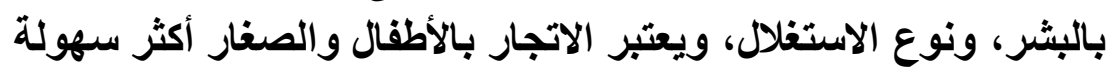

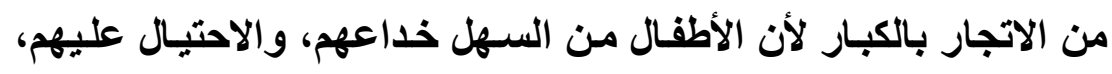

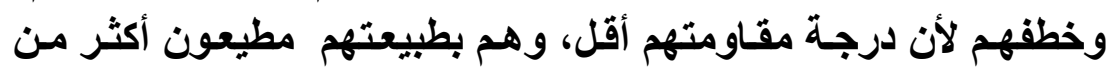


الكبار، واحتمـال استغلالهم للعمل والجنس أكثر، وقد تثتتمل عمـالتهم

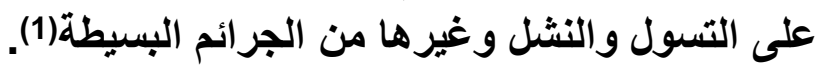
ثانياً الجنس: يستهدف الاتجار بالبثر جنس الإناث أكثر من فن

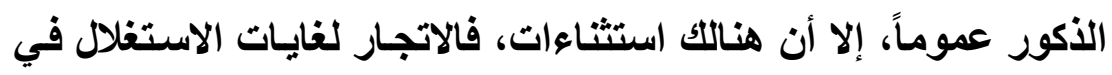

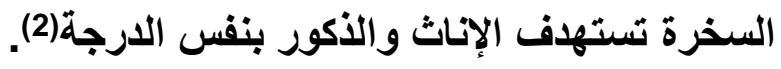

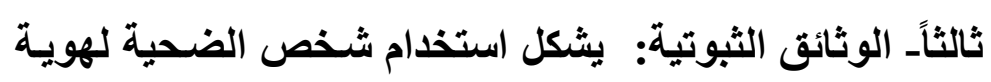

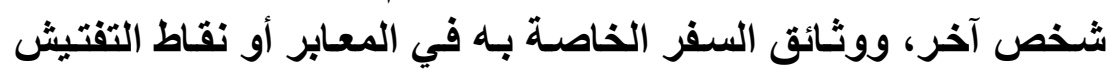

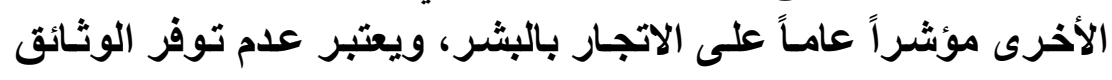

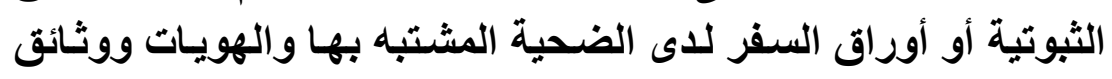
السفر المزورة عوامل دالة لوقوع الضحية للاتجار (3).

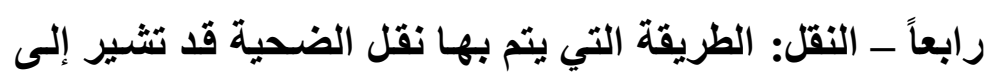

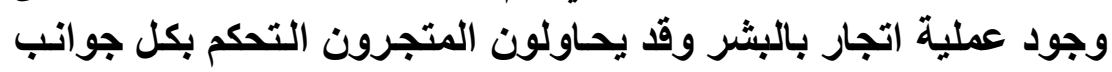

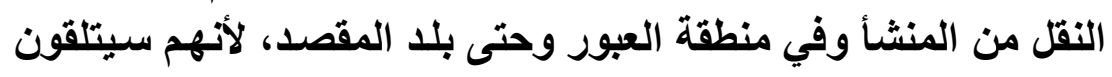
المال مقابل الضحايا في المقصد النهائي(4).

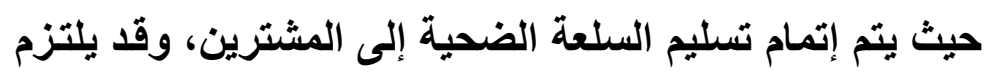
المتجرون بالبشر بخط نقل واحد لفترة زمنية طويلة لكونهم انثـاءوا

(1) د. آن جوردان، الدليل المشروح لبروتوكول الأمم المتحدة لدكافحة الاتجار

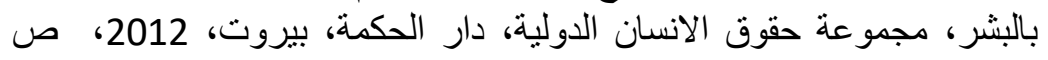

Andrew Karmen: Crime Victime; An Introduction to victimology, eighth Edition, Belomont, USA, 2012. P 82.

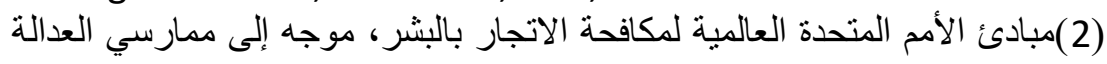

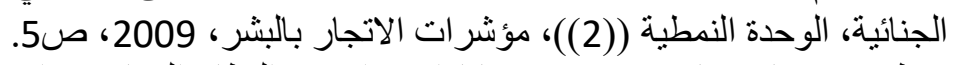

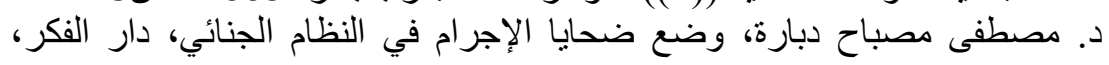

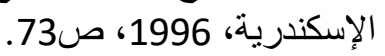

)3(Von Hentig. Hans - Remarks on the interaction between perpetrator and victims - Journal of the American institute of criminal law and Criminology Vol. 31. 1997. P. 143.

)4(Mende Isohn. B.A, New Branch of Biopsychologyical seience "La victimology: Revue international de Criminologie et depolice Technique No.2. 1999. P. 58. 


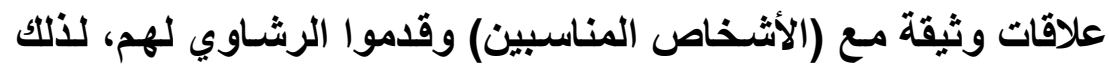

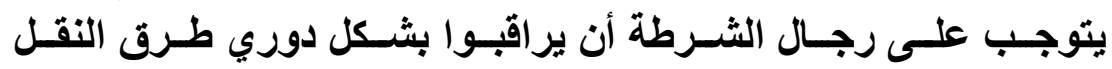

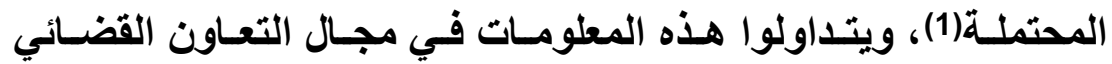

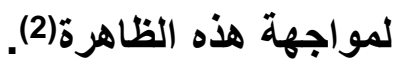

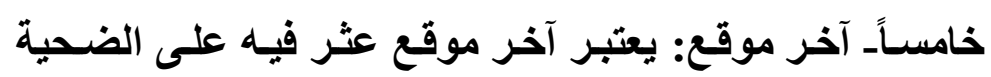

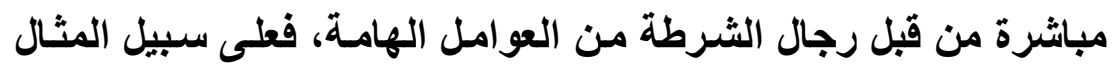

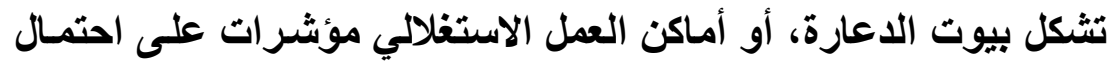

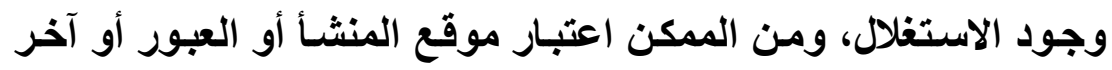

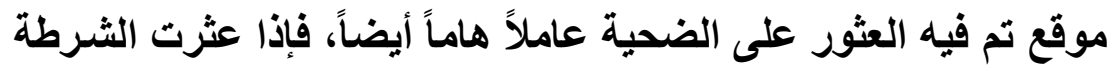

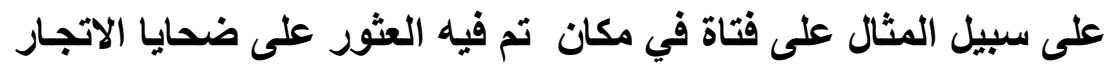

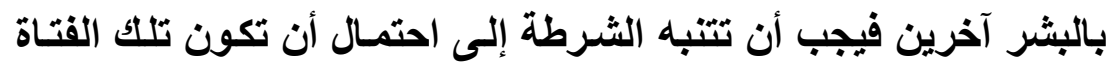

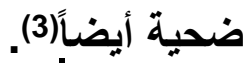

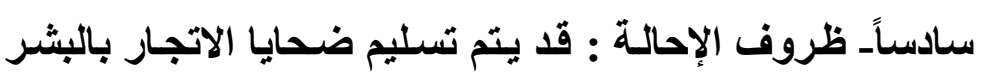

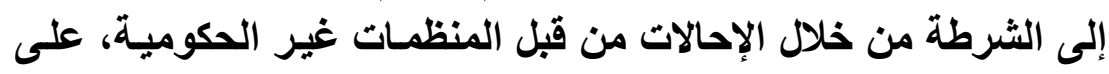

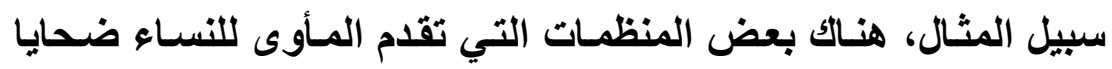

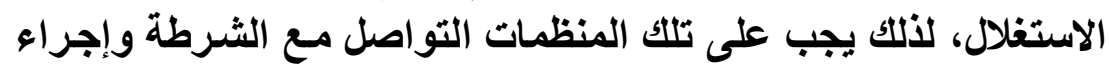

(1) د. ناجي هلال، التحليل الاجتماعي لضحايا الجريمة، بحق منشور في مركز

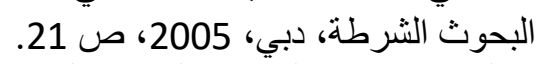

د. نور الدين هنداوي، المجني عليه بين القانون الجنائي و علم الإجرام، مجلة الثنريعة

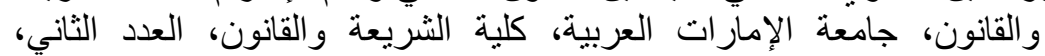

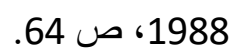

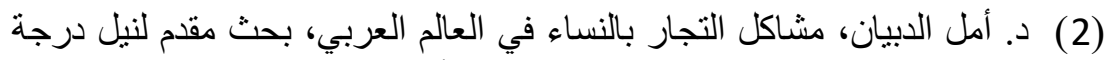
الدكتوراه في الثؤون الدولية والدبلوماسية، الأكاديمية السورية الدولية، لئل 2010،

د. وائل احمد علام، الحماية الدولية لضحايا الجريمة، دار النهضة العربية، القاهرة،

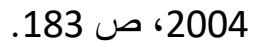

(3) المؤتمر الإقليمي حول تعزيز دور منظمات المجتمع الدني في مكافحة الاتجار بالبشر في المنطقة العربية، عمان، 29-30 سبتمبر 2010 
مقـابلات مـع الضـحايا لتحديد مـا إذا كـان هنـاك جريمـة اتجـار بالبشـر محتملة (1).

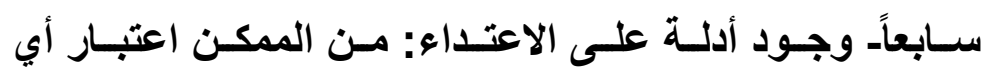

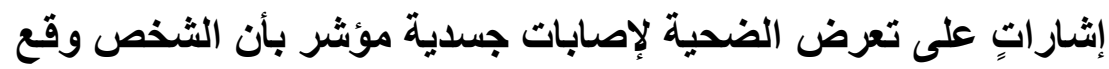

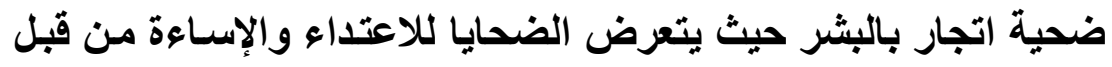

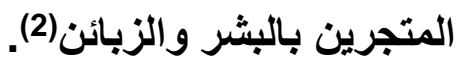

(1) المؤتمر الإقليمي حورل تعزيز دور منظمات المجتمع المدني في مكافحة الاتجار

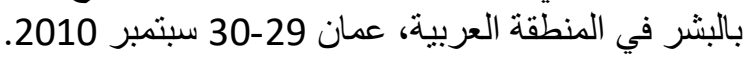
(2) مؤتمر الأطراف في اتفاقية الأمم المتحدة لككافحة الجريمة لمنظمة عبر الوطنية، فينا، (12-12) تثرين الأول/ أكتوبر 2011. COP/WG4/ 2001/4/P.3 


$$
\text { الفرع الثاني }
$$

المؤشرات الخاصة الدالة على ضحية الاتجار بالبشر

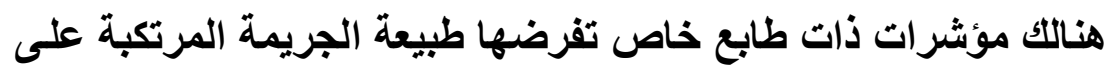

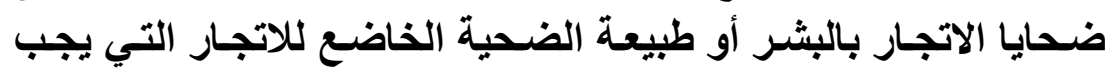

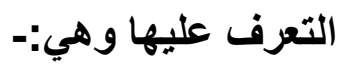

أولاً: المؤشـرات الدالـة على الضـحية الطفل: يمكن أن يتسم الأطفـال

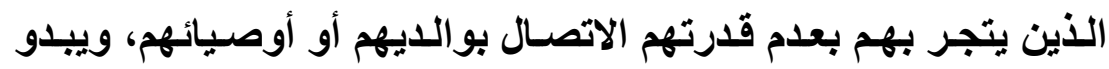

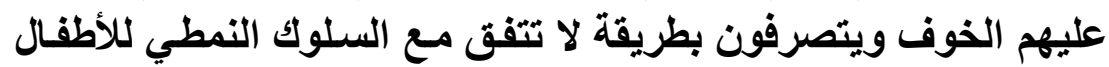

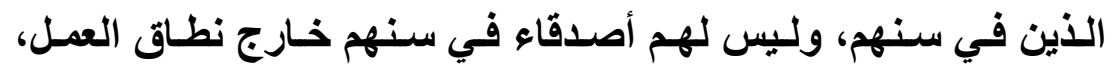

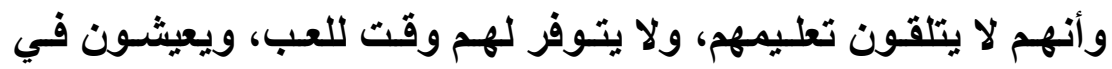

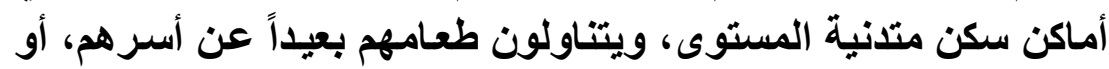

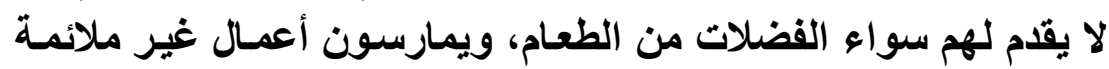

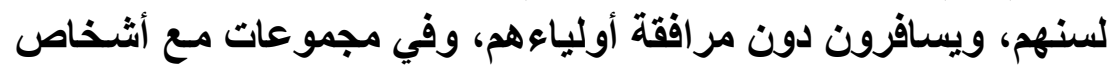

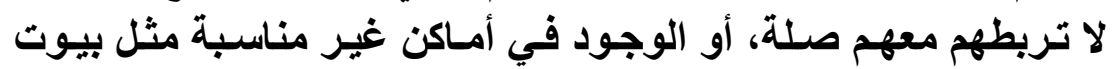

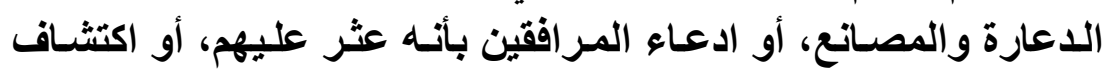

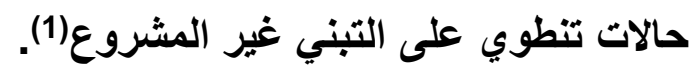
ثانياً: المؤشرات الدالة على ضحية العبودية المنزلية

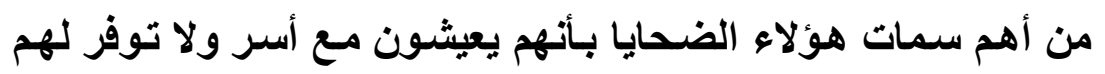

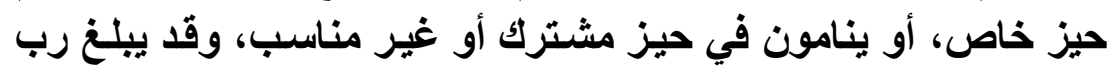

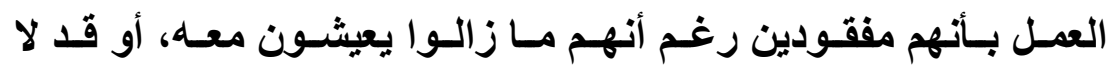

(15) المؤتمر القضائي المغربي حول الحماية عبر الحدود للأطفال و العائلة، من (3- الأون،

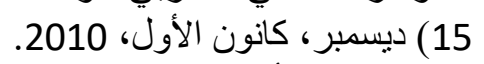

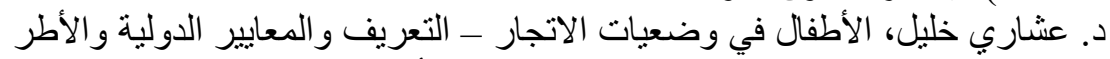

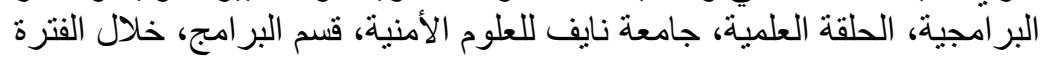

(2006/(22-18) 


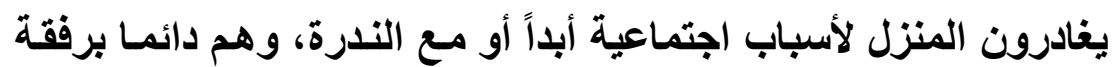
رب العمل، ويتعرضون لإساءة المعاملة أو التهايد أو العنف(1). ثُالثاً المؤشر ات الدالة على ضحية الاستغلال الجنسي:

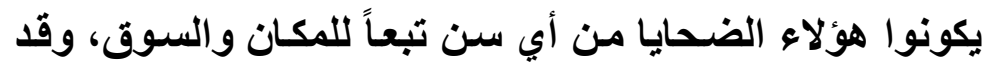

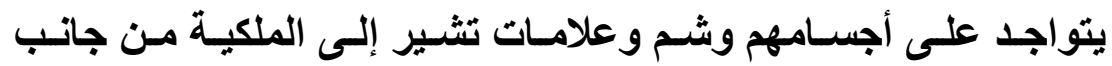

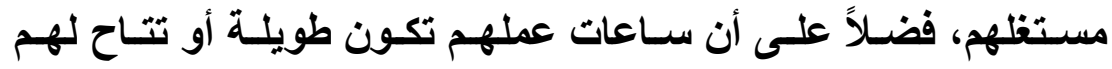

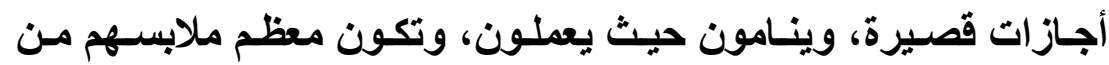

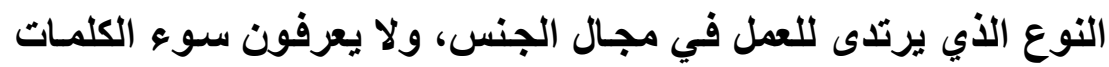

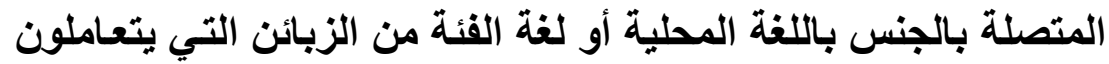

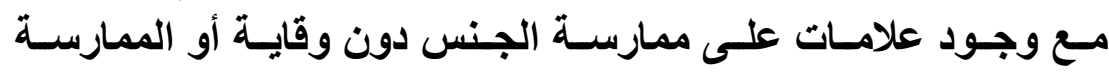

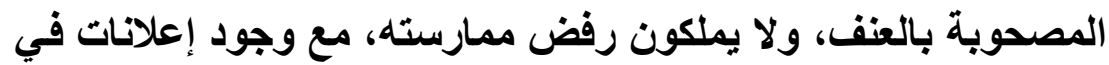
أماكن مشابهة تعرض خدمات النساء كأماكن التدليك(2). رابعاً المؤشرات الادالة على ضحية الاستغلال في العمل

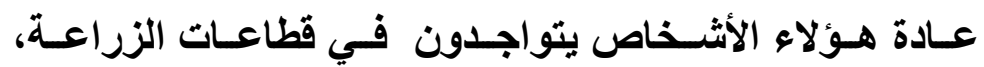

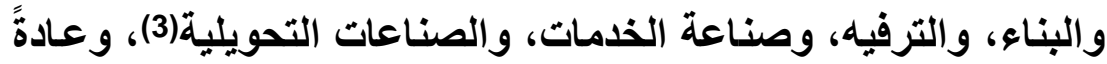

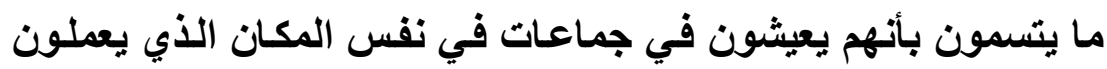

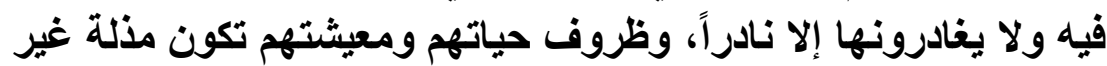

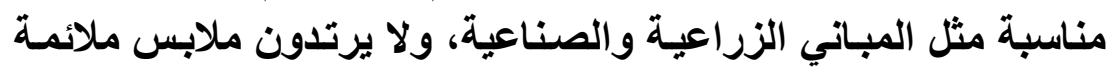

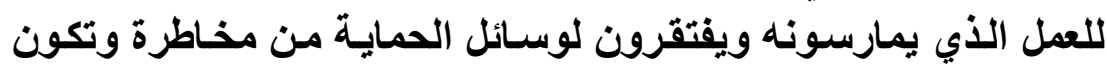

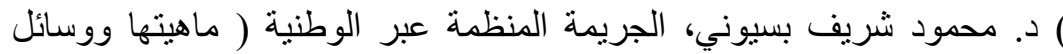

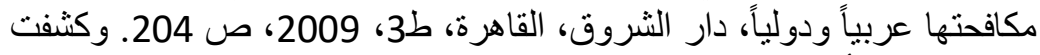

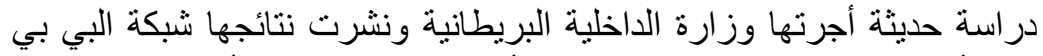

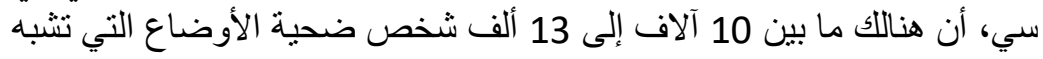
uk العبودية في بريطانبا، موقع هيئة الإذاعة البريطانبة، موقع إيلاف الإخباري world news www.bbc.Co

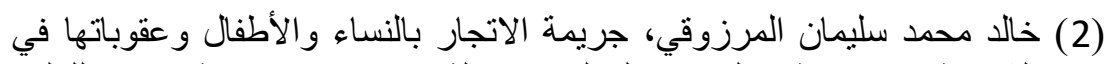
الثريعة الإسلامية والقانون الدولي، رسالة ماجستير، جامعة نايف الإنيف للعلوم

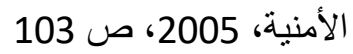

د. سوزي عدلي ناثند، الاتجار في البشر بين الاقتصاد الخفي والاقتصاد

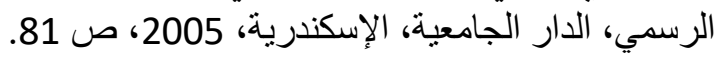


عــادةً ســاعات عملهـم طويلـة، ولا يتقاضـون في كثيـر مـن الأحيـان

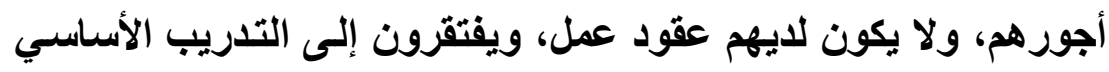

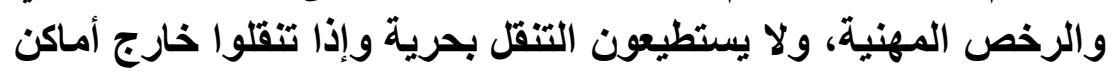

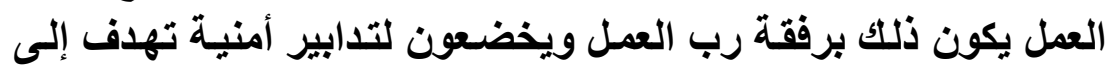

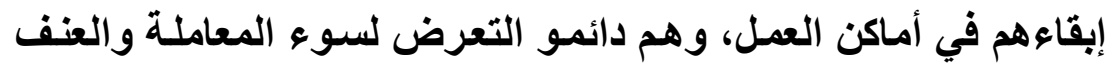

$$
\text { خامساً: المؤشرات الدالة على ضحية التسول }
$$

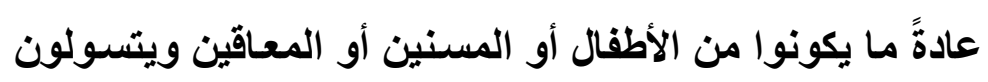

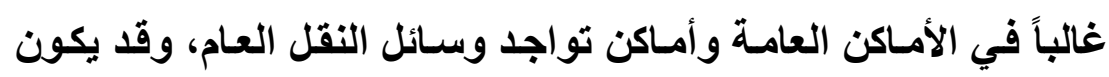

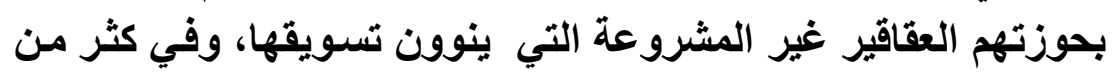

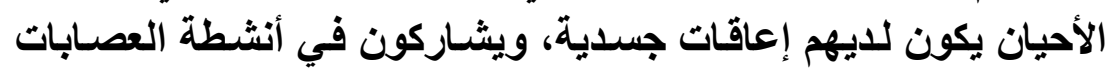

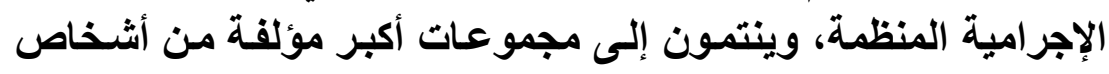

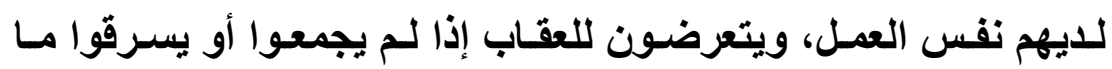

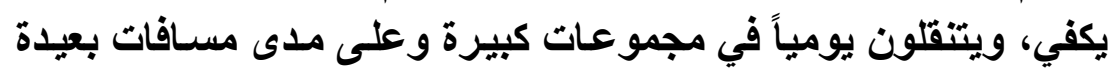
برفقة أثخاص ليسون آباءوهم.

(1) د. محمد فتحي عيد، عصابات الإجر ام المنظم ودور ها في الاتجار بالأشخاص،

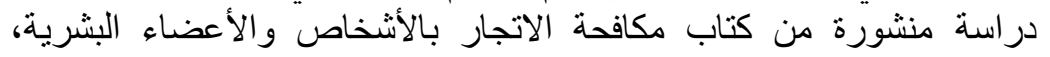

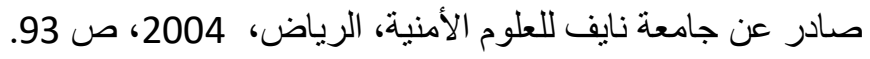




\section{المبحث الثاني}

حقوق ضحية الاتجار بالبشر أثناء الإجراءات الجنائية

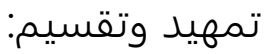

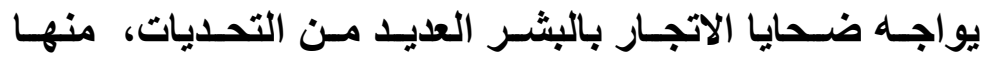

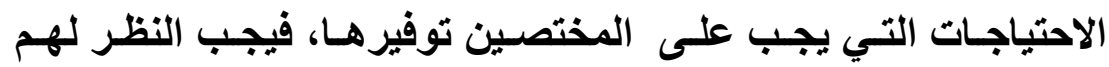

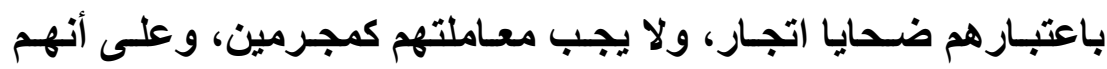

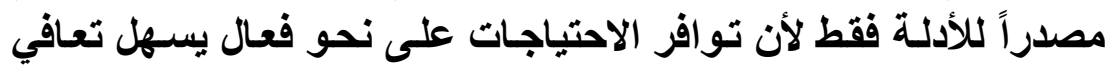

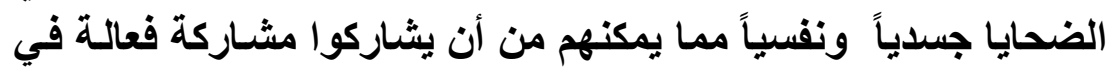

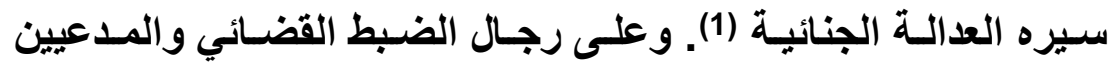

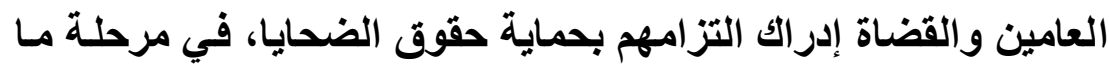

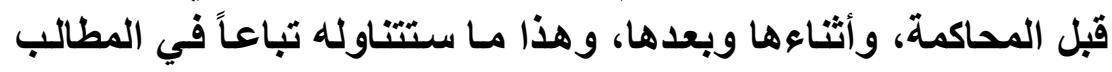

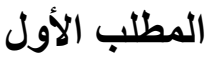

حقوق الضحية في مرحلة التحري والاستدلال(2)

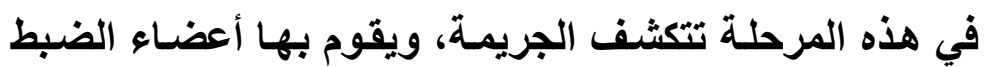

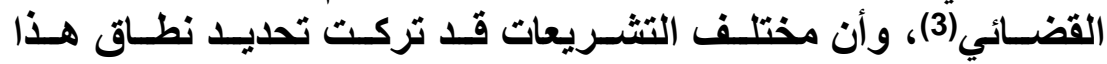

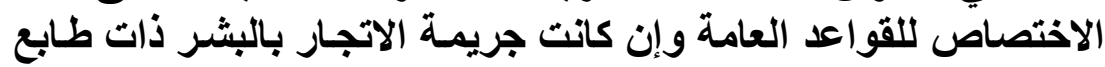

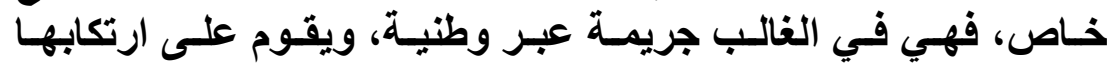

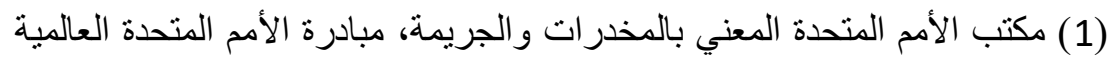

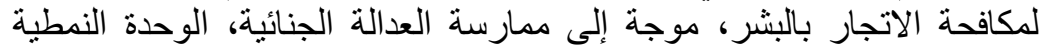

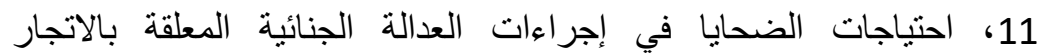

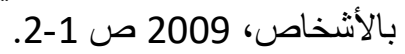

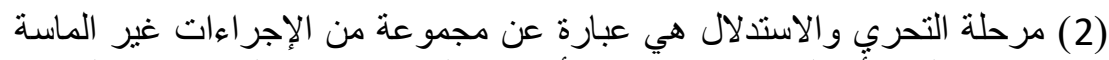

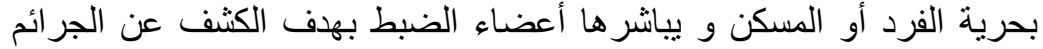

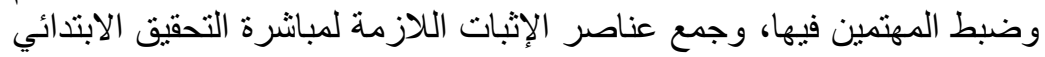

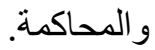
(3) ففي قانون أصول المحاكمات الجزائية الأردني يطلق وصف الضبط القضائي

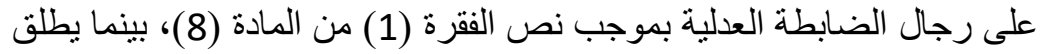

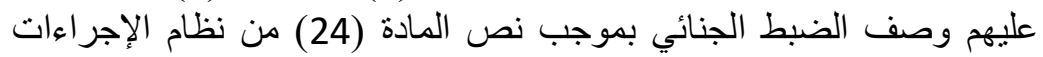

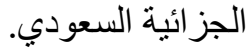




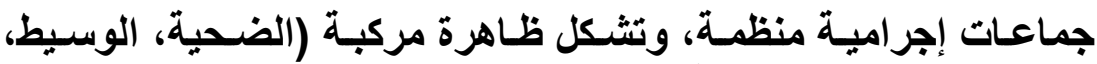

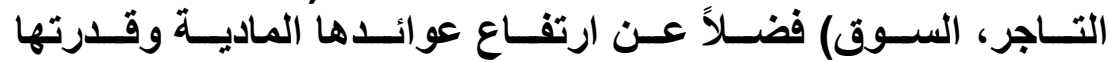

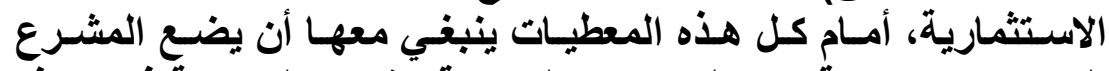

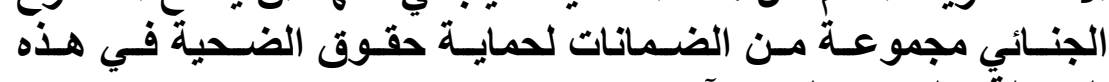
المرحلة والتي نجملها كالآتي:

أولاً: عدم الإفصاح عن هوية الضحية المبلغ عن جريمة الاتجار بالبشر يجب على مأمور الضابط القضائي قبول البلاغات التي ترد إليه

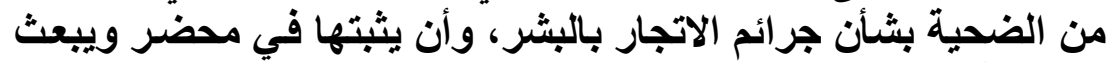

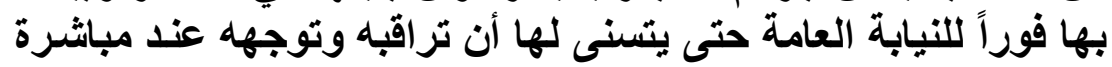

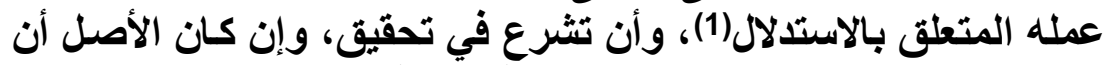

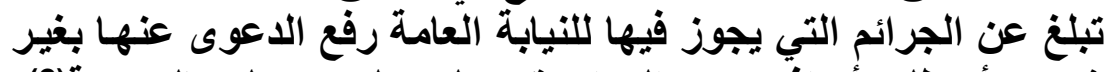

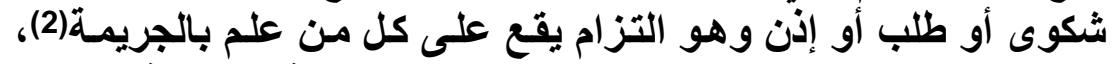

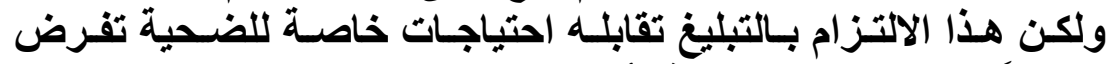

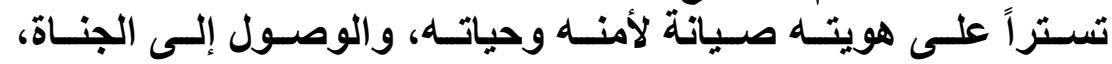

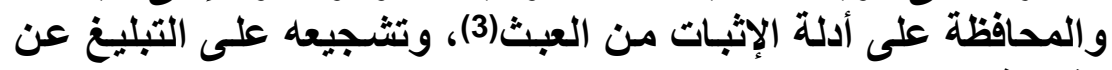
مثل هذا النوع من الجر ائم(4).

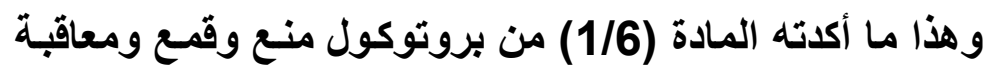

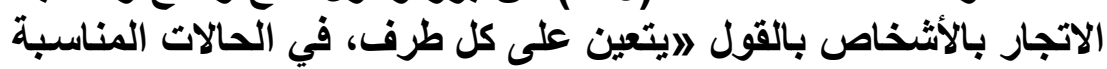

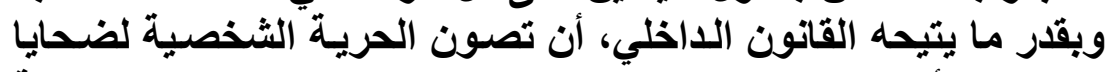

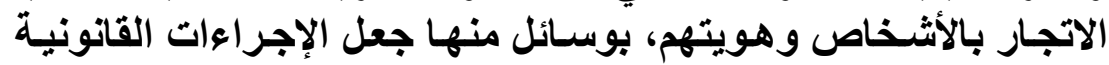

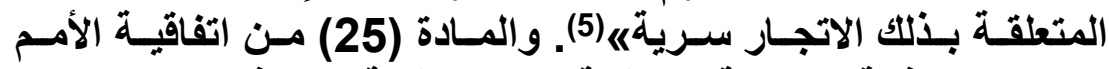

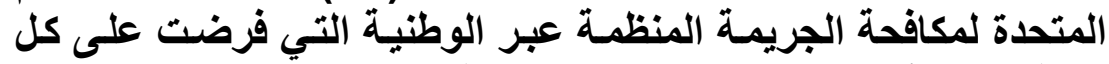

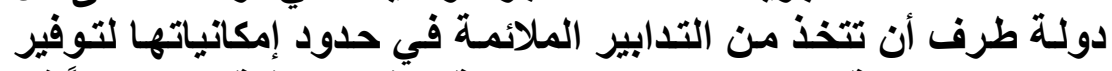

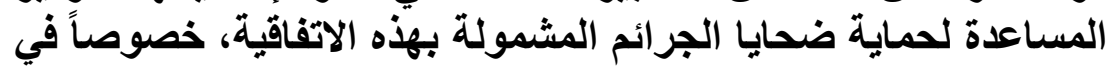

$$
\begin{aligned}
& \text { (1) د. سعد محمود سلامة، التبليغ عن الجرائم، دار الفكر العربي، الإسكندرية، } \\
& \text { 2003، ص } 408 \text { و وما بعدها. } \\
& \text { (3) أنظر المادة (37) من قانون الإجراءات الجزات الجزائية الاتحادي الإماراتي. }
\end{aligned}
$$

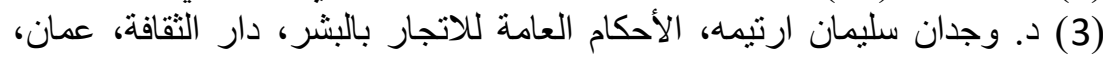

$$
\text { 2014، ص ون } 241 \text { وما بعدها. }
$$

)4( Naoum salamé, Génétique moléculaire et spécificités humaine, Jean- claude Hervé, 2013, p53 ets

(5) و هذا كذللك ما أكدنه توصيات منظمة الصحة العالمية الأخلاقية والأمنية في مقابلة

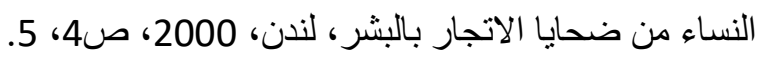


حالات تعرضهم للتهديد بالانتقام أو الترهيب. وسـارت على هذا النهـ التهرج

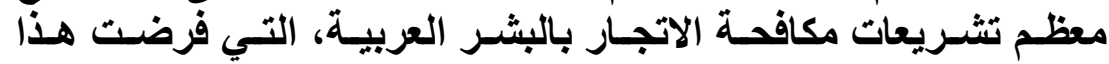

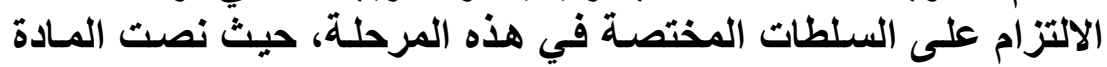

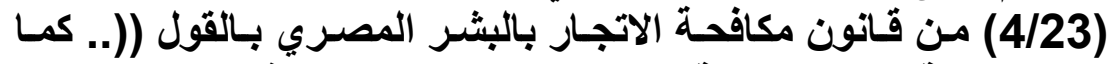

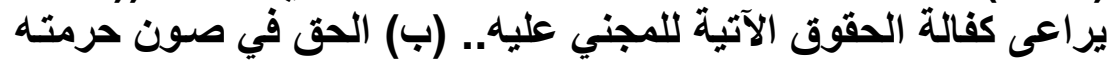

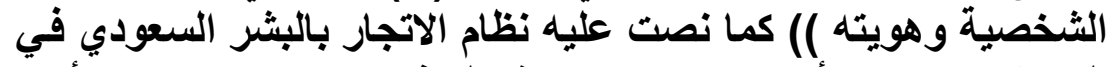

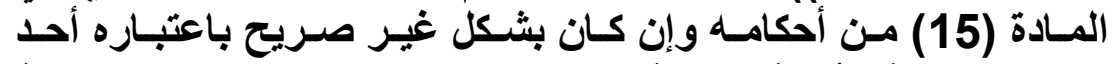

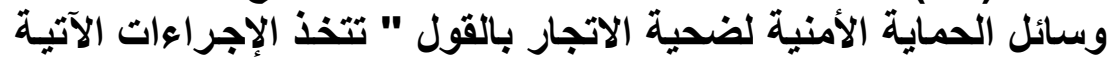

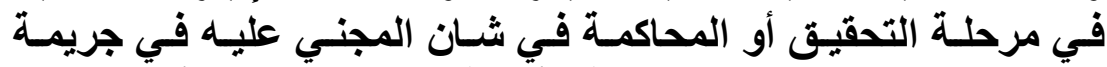

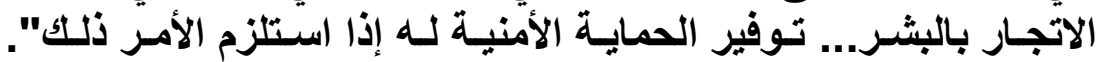

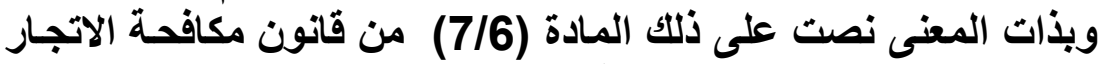

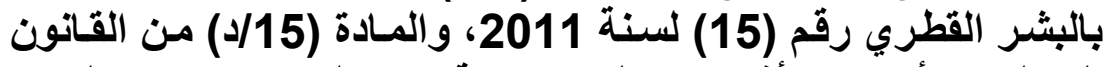

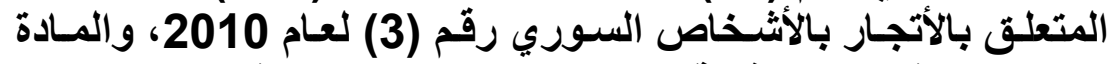

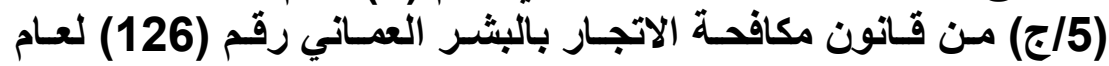

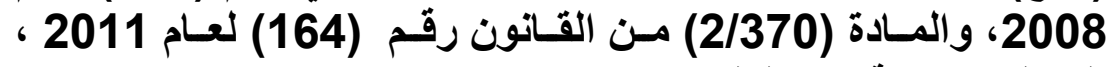
المعدل لاحكام قانون العقوبات.

ونلفت النظر بأن التعديل الأخير لأحكام قانون العقوبات اللبناني

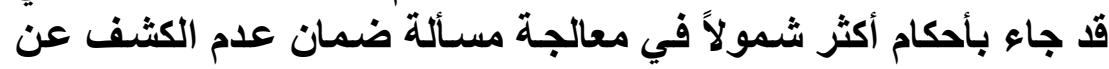

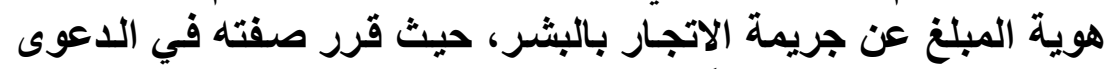

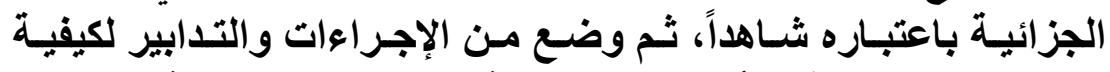

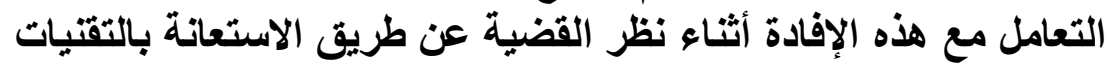

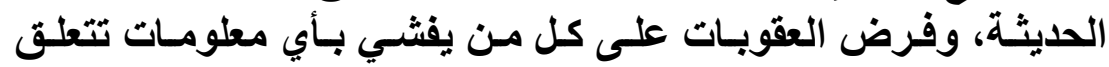

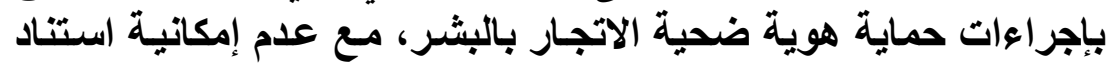
حكم الإدانة على الإفادة وحدها (1).

(1) تنص المادة (2/370) من القسم الثاني مكرر من قانون رقم (164) تاريخ

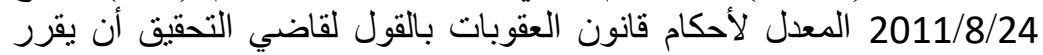

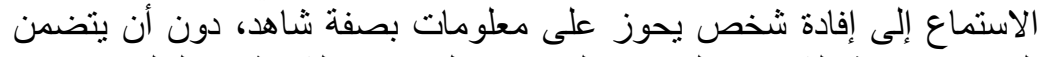

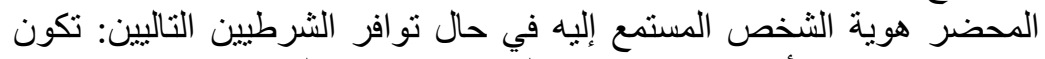

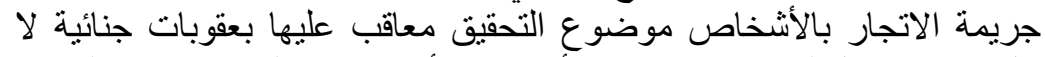

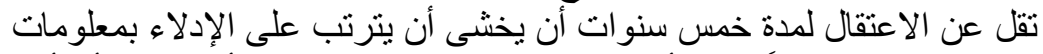

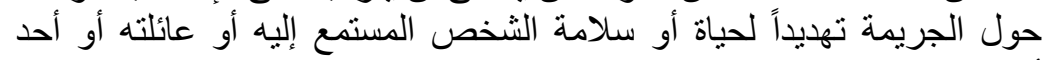
يجب أن يكون القرار معلاًً وأن يتضمن الأسباب الواقعية والمادية التي استند عليها

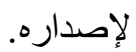


وهذا المسلك الإيجابي من المشرع اللبناني، يتوجب على كافة

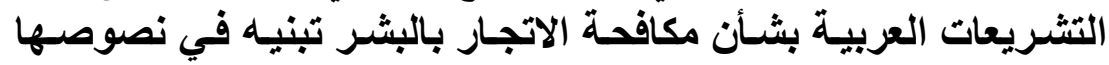

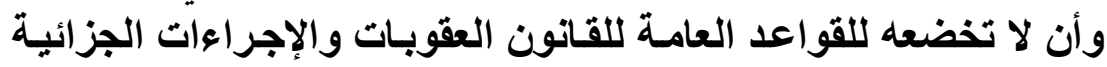
بسبب الخصوصية التي تمتع بها هذه الجريمة

تدون هوية الثخص و عنوانه في محضر خاص، لا يضم إلى ملف القضية، يودع

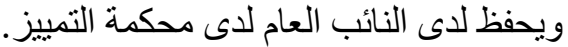

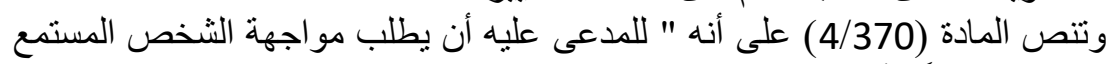

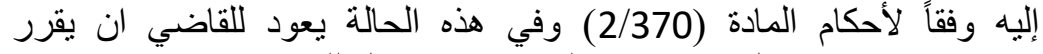

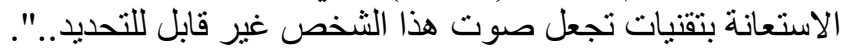

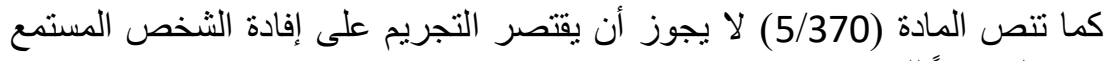
إليه وفقاً للمادة (2/370) (لادة (5/370) بجري

ونصت المادة (6/370) بالقول بعاقب من أفنى معلومات حول إجراءات الحماية

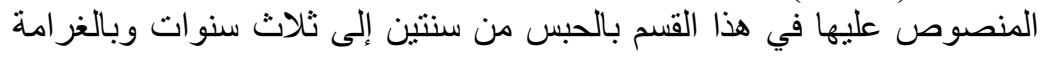
من عشرين مليون إلى ثلاثين مليون ليرة لبنانية. 
ثانياً: إعلام الضحية بحقوقه القانونية

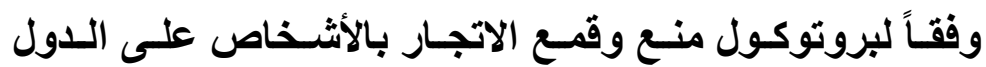

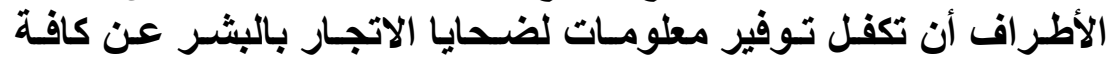

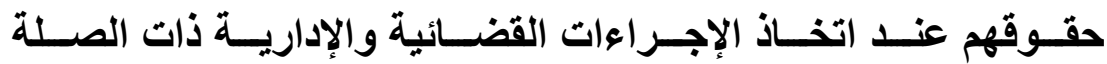

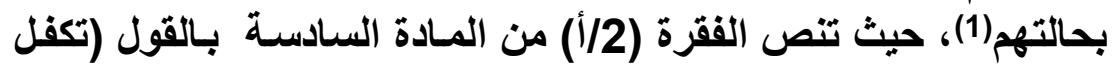

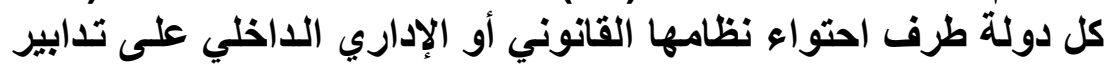

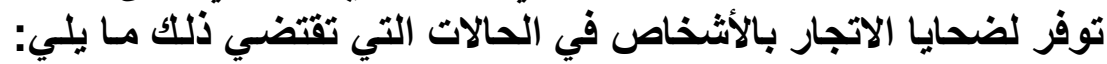

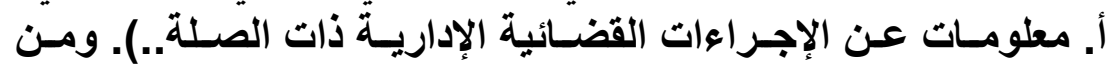

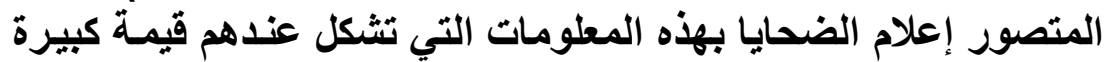

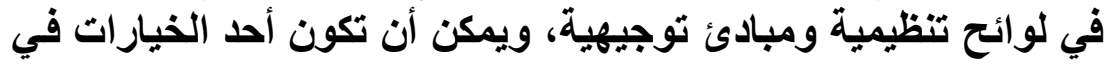

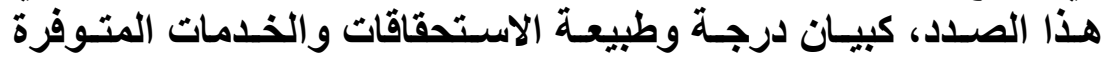

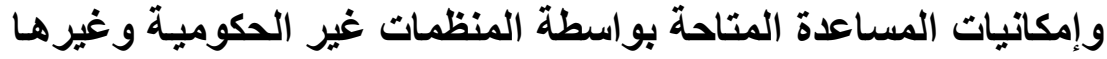

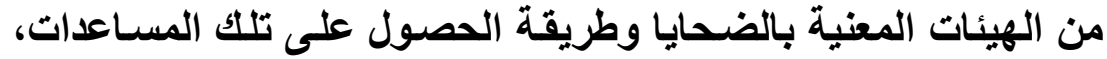

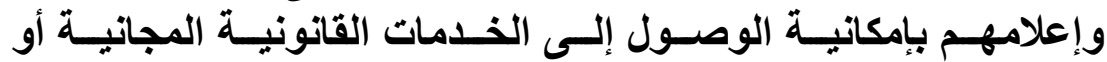

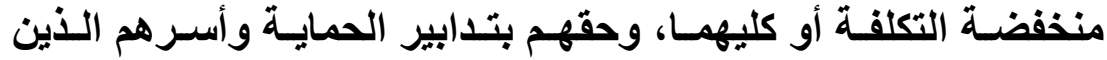

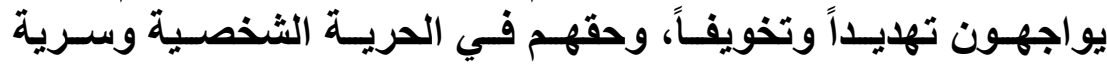

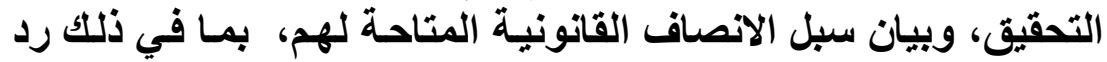

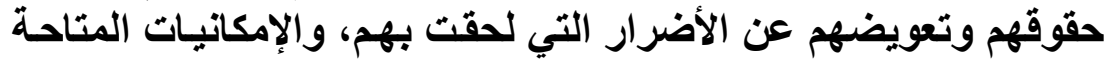

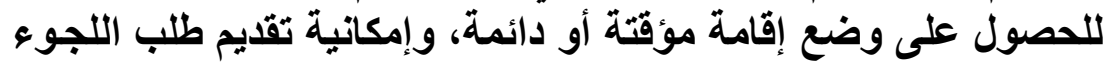
أو الإقامة بناء على أسباب إنسانية وخاصة بالر أفة (2)

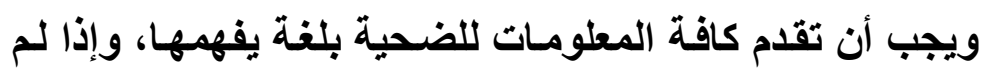
يكن بمستطاع الضحية القراءة، يجب على السلطة المختصة أن تبين له له

(1) و هذا الحق أيضاً أكدته المادة (19) من القانون النموذجي للاتجار بالبشر المقتر ح

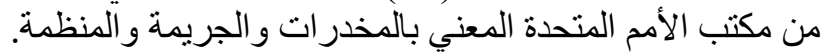

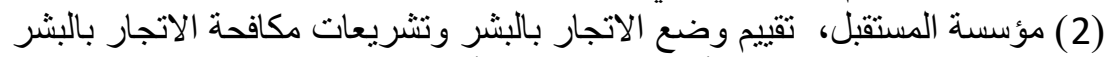

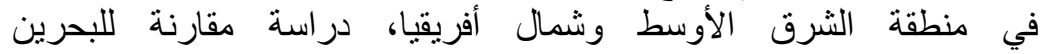

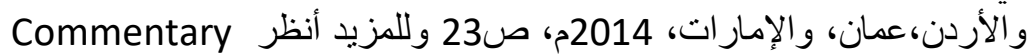
on the

Recommended principles and Guidelines to Human Rights and Human Trafficking (united nation publication, sales No. E.

.10. XIV.1) PP. 141,151 


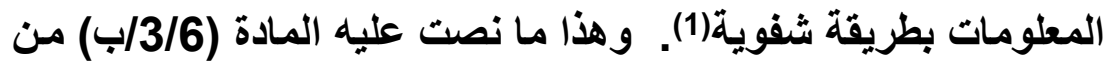

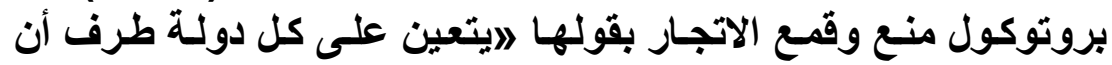

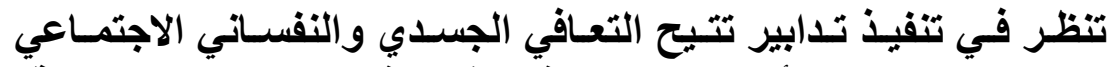

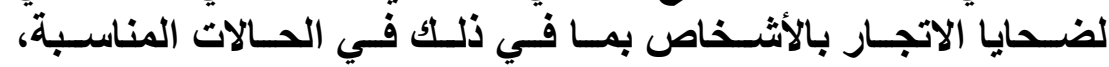

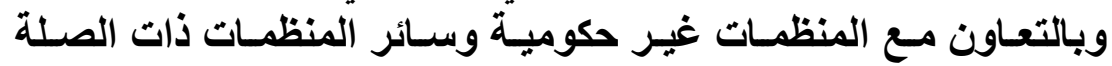

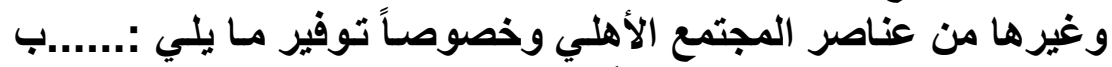

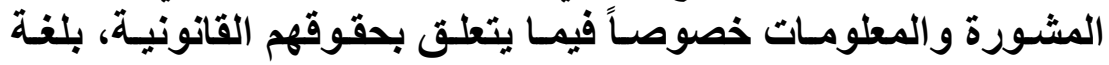
يمكن لضحايا الاتجار بالأشخاص فهمها.

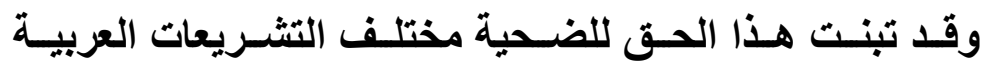

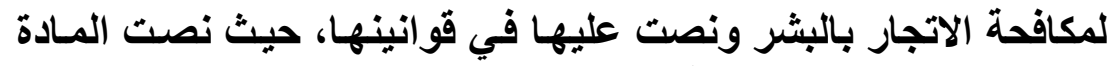

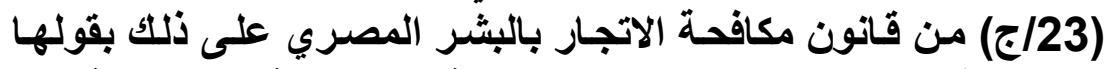

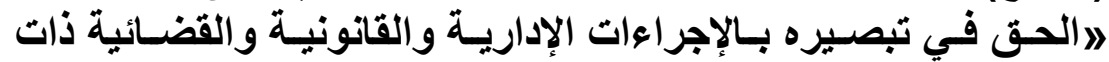

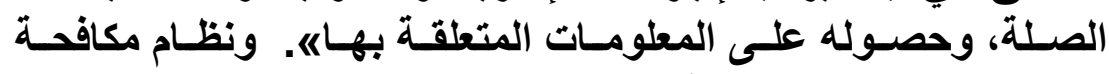

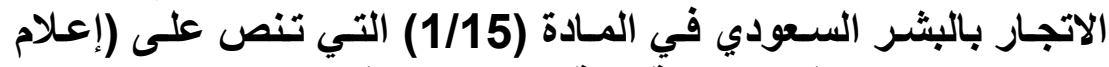

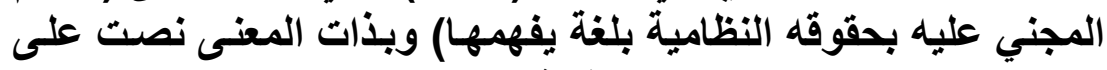

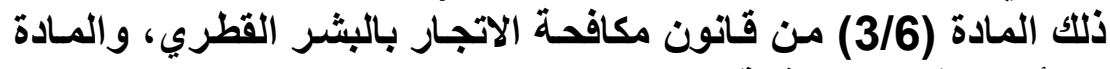

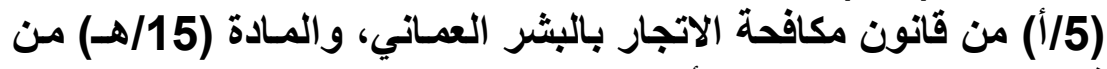

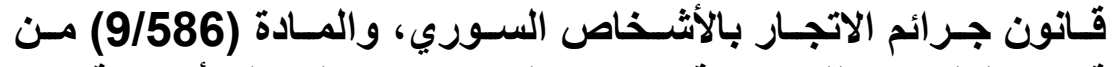

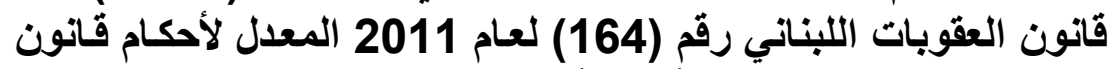

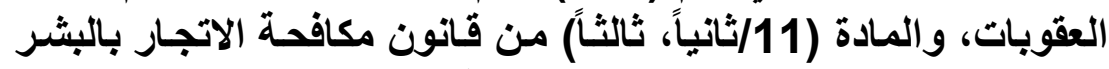
العراقي، والمادة (1/5) من قانون مكافحة الاتجار بالبشر البحريني. ثالثاً: حق الضحية في المأوى اللائق

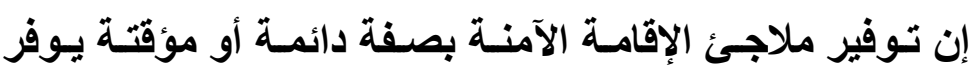

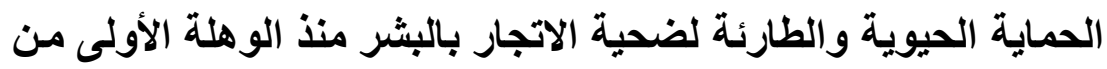

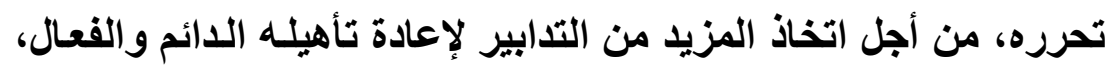

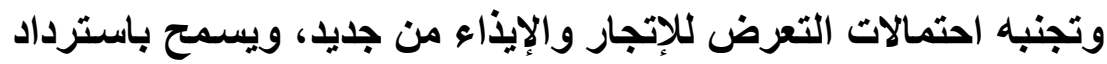
ثقتهم في أنفسهم وسلطات الضبط القضائي، ويجعلهم أكثر تعاوناً على ولى 
تقديم مـا لليهم من معلومـات وأدلة تسـاعد هذه السلطات على ضبط الجناة وتقايمهم للعدالة) (1).

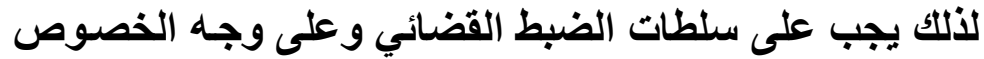

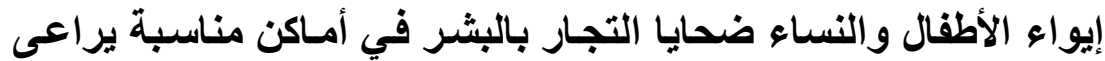

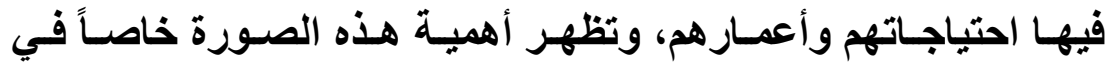

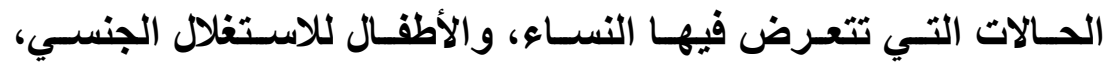

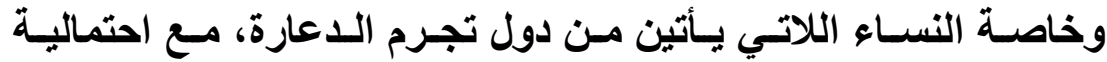

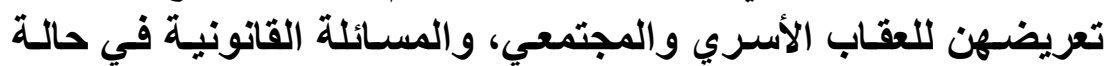

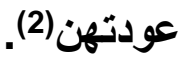

ومن المتصور أن يمتد هذا الحق إلى أسرة الضحية المتوفاة

وفقاً لقواعد الإنصاف الفعالة)(3ن.

وفي سبيل ذلكت جـاء بروتوكول منـع وقمـع ومعاقبـة الاتجـار

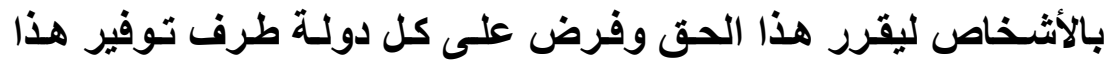

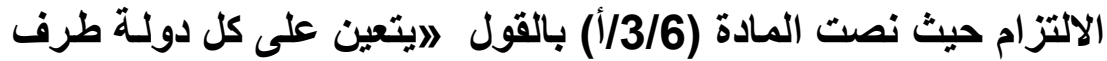

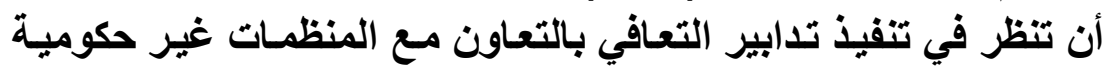

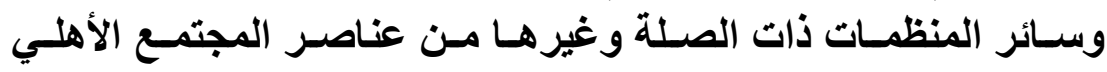
وخصوصا ما يلي : أ. السكن اللائقه.

ووفقاً للملحوظات التفسيرية فإن الحكم الخاص بنوع المسكاعدة

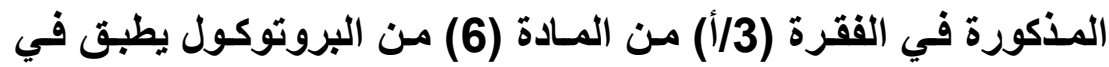

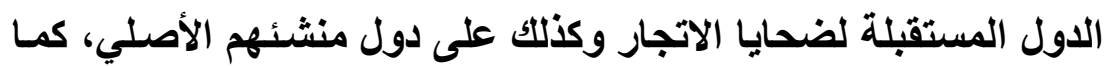

(1) OHCHR, UNHCR, UNICEF, UNODC, UN women and ILo, Joint Un Commentary on the Eu- Directive - A Human Rights Based Approach , 2011, p. 56.

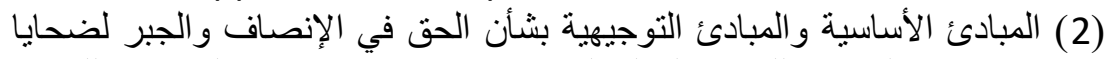

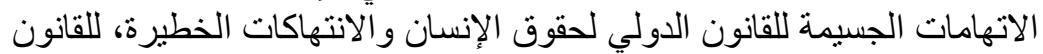

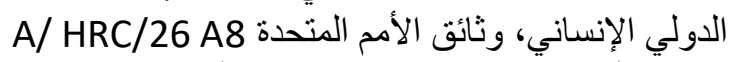

A/ ونائق الأمم المتحدة، نقرير مفوضية الأمم المتحدة / مجلس حقوق الإنسان الأنسان .HRC/ 26/ 18, 2 May. 2014 
يطبق الحكم على الدول المستقبلة إلى أن يعاد الضحية إلى دولة منشئه

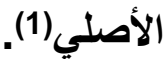

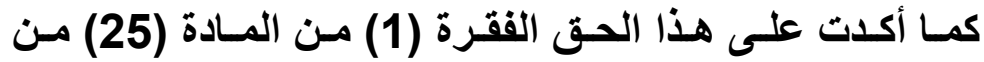

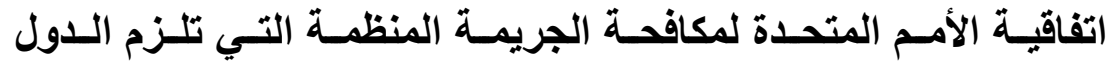

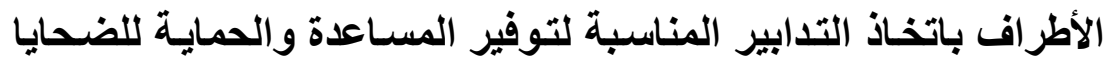

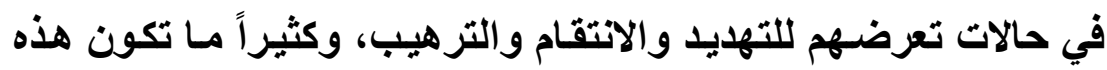

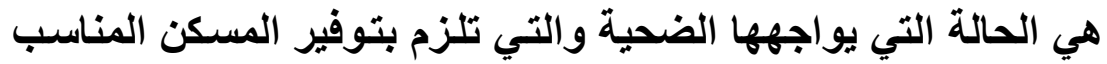

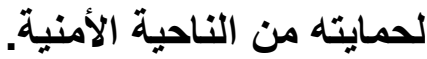

وقد جاعت التشريعات العربية لتقرر هذا الحق لضحية الاتجار

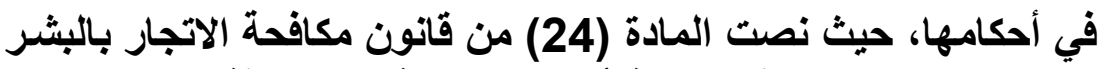

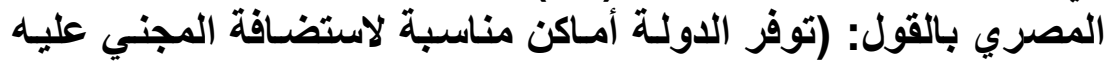

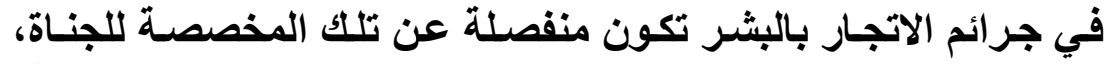

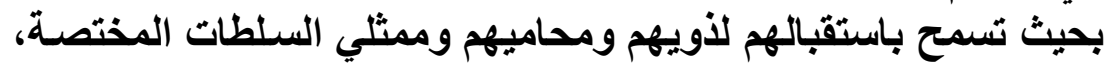

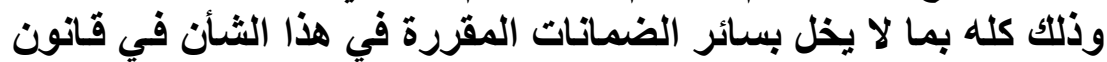

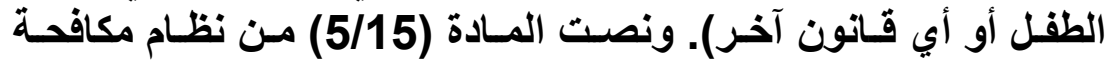

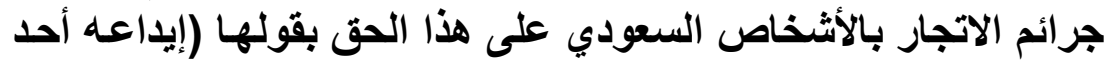

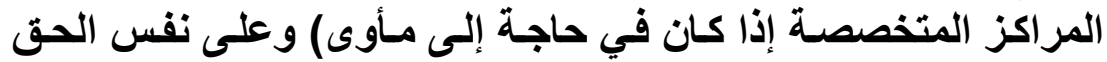

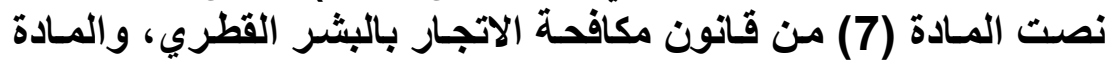

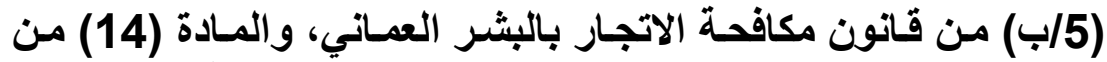

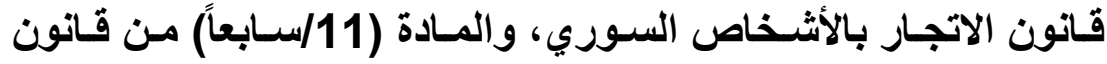
مكافحة الاتجار بالبشر العراقي، والمادة (7) من قانون مكافحة الاتجار

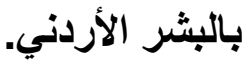


ويلاحظ في هذا المجـال إن كانت مختلف التشريعات قد أقرت هـا الحق لضـحية الاتجـار إلا أن أغلب الـدول لـم تفتح دوراً لإيـواء ضحايا الاتجار على أرض الواقع فمثلاً في الأردن، والإمـارات العربية المتحدة، والبحرين، فإن هذه المركز تقتصر فقط على استقبال النسـاء والأطفال ولفترة وجيزة ومؤقتة (1).

ويجـوز للسـلطات المختصـة عنــدما تقتضــي الضـرورة صـونـاً

للسلامة الجسدية للضحية أو بنـاء على طلبه أو بالتشـاور معه، اتخـاذ كافة التدابير اللازمـة لتغير مكان إقامتـه، وفرض القيود بعدم الكثف لهف عن عنوانـه وذلــك بالقـدر الممكن، حيث نصـت المـادة (5/24) مـن بروتوكول منـع وقمع ومعاقبـة الاتجـار بالأشـخاص بـالقول ((... يتعين على كل دولـة طرف أن تسـى إلى تـوفير السـلامة الجسـية لضـحايا الاتجار بالأشخاص أثناء وجودهم داخل أقليمها) (2).

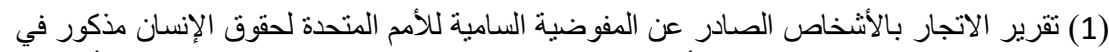

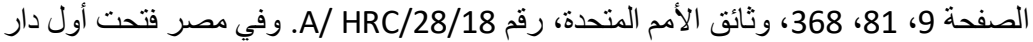

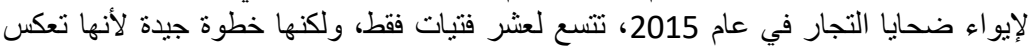
بداية الا هتمام بضحايا الآتجار. (2) وقد أكدت هذا الحق المادة (1/2/24) من الفاقية الأمم المتحدة لمكافحة الجريمة المنظمة التي التئي

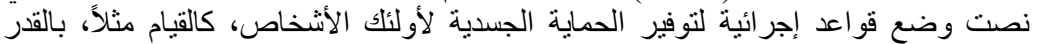

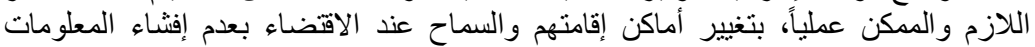

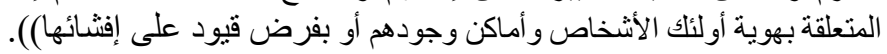


والجـير بالـذكر أن معظم تثـريعات مكافحة الاتجـار بالبشـر

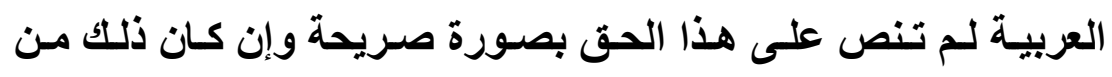

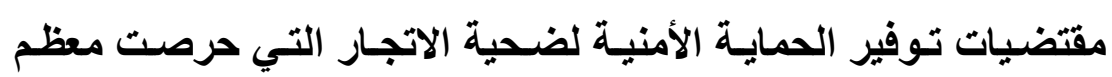
التشريعات على صيانته(1). رابعاً: حق الضحية في التعافي والتفكير والإقامة

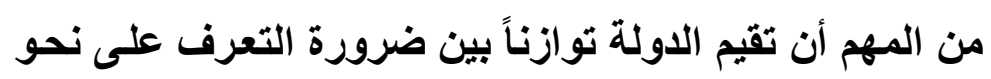

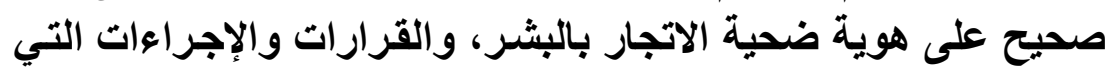

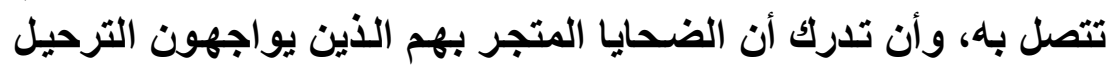

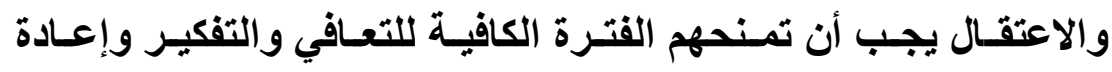

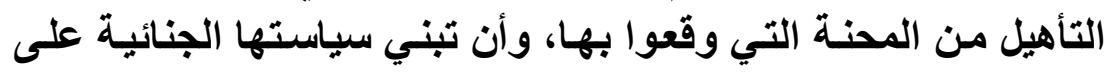

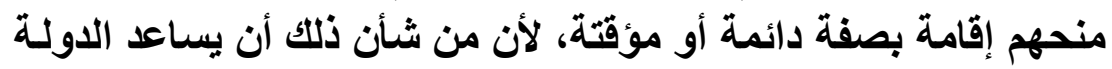

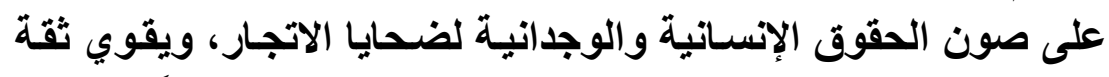

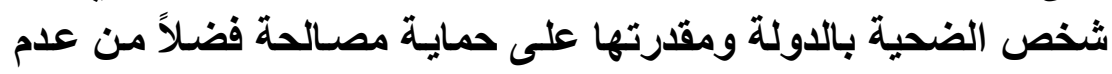

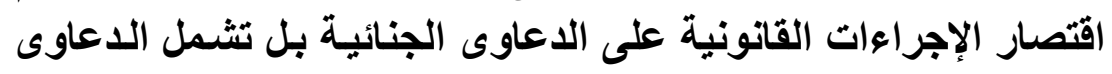

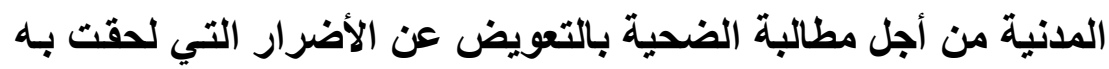

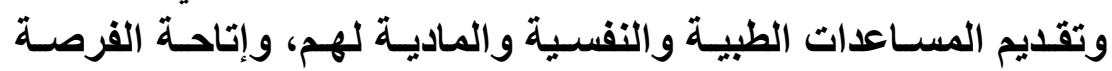

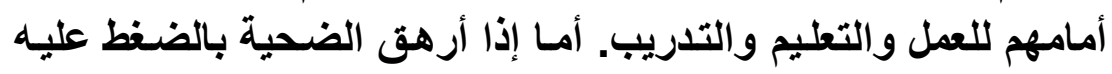

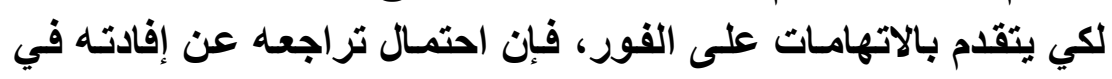

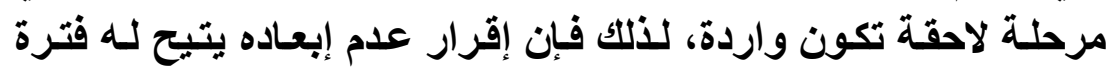

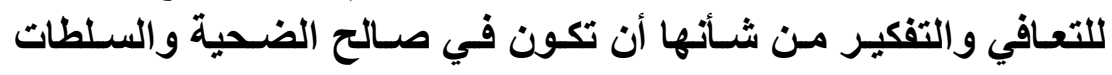

(1) و هذا ما نصت عليه المادة (23/15) من قانون مكافحة الاتجار بالبشر المصري، و المادة

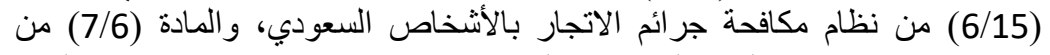

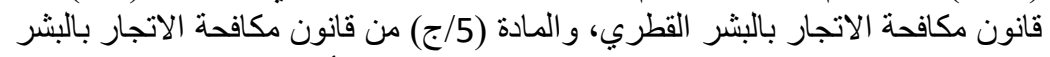

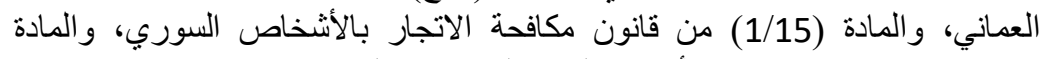

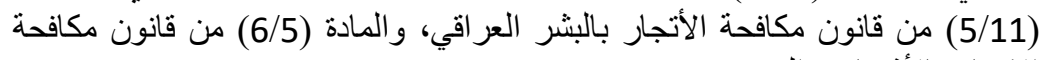
الاتجار بالأشخاص البحريني. 
العامة وتمكن سلطات الضبط القضـائي من مباشرة ومتابعة التحقيقات

والتحريات بصورة أفضل(1).

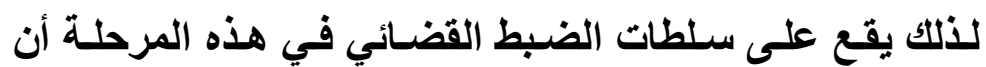
تمنح أي شخص طبيعي تعثقد بأن له أسباب معقولة تدعو للاعتقاد بأنسا

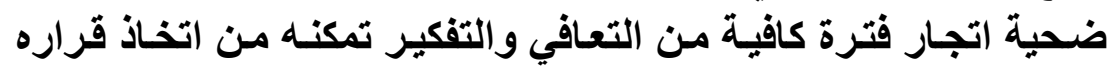

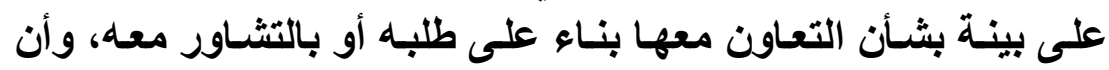

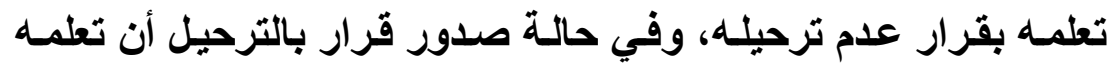

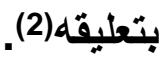

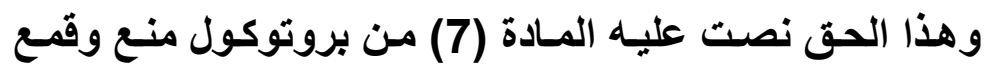

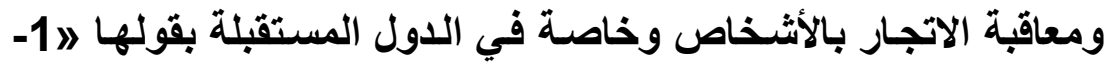

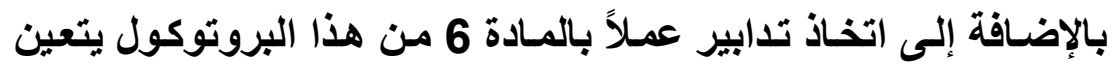

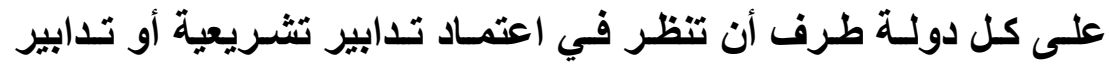

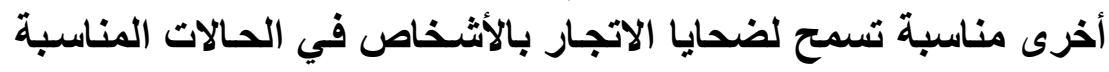

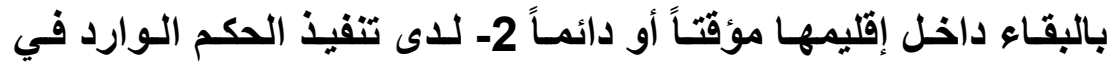

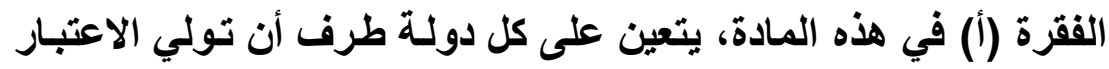

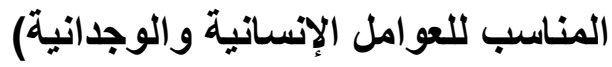

وقــ تفاوتـت التشـريعات العربيـة المختصــة بمكافــة الاتجـار

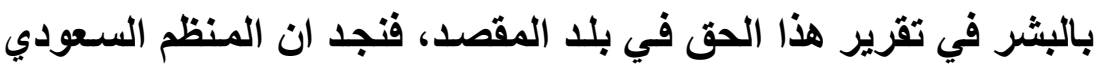

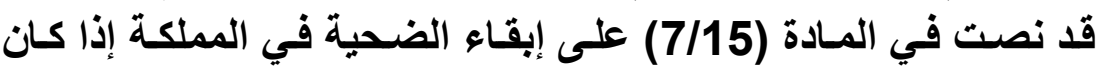

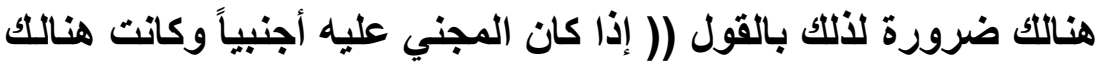

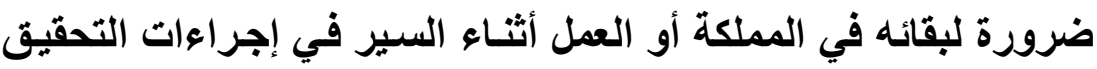

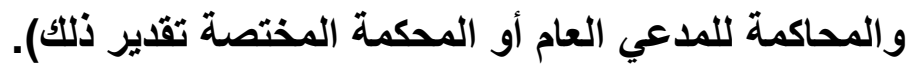

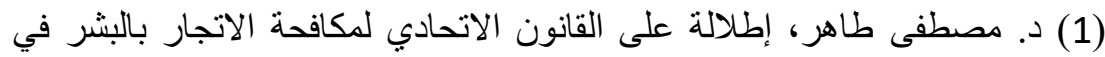

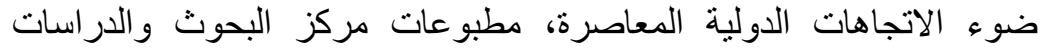

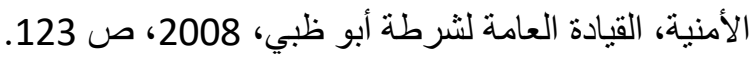

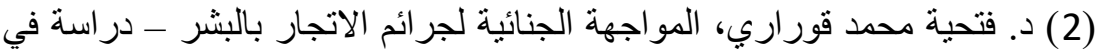

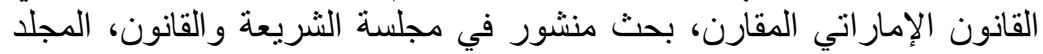
الأربعون، 2009، صن الأمي المقارن، 23. 
وهذا مسا أخذ المشـرع العمساني في المسادة (5/د) مسن قـانون

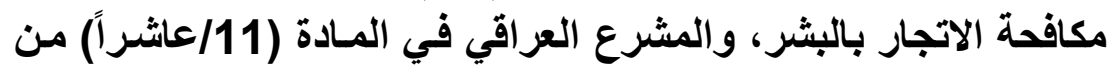

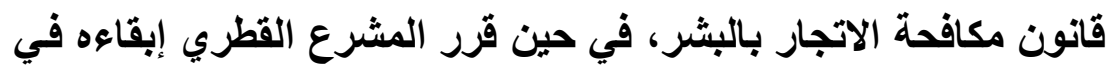

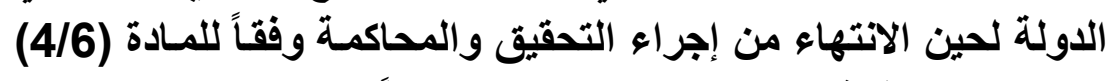

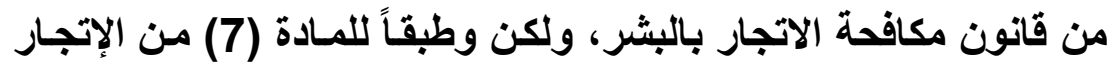

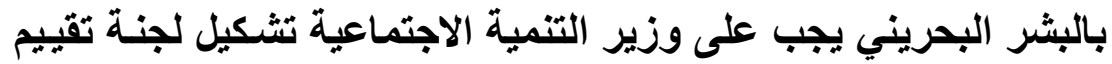

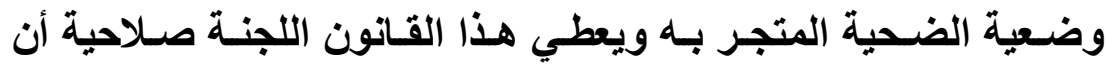

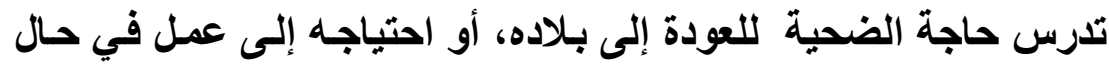

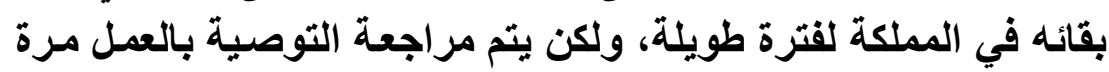

على الأقل كل ستة أشهر (1).

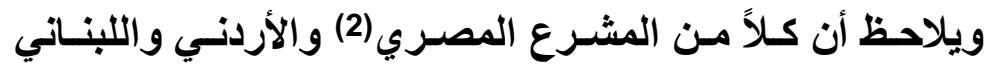

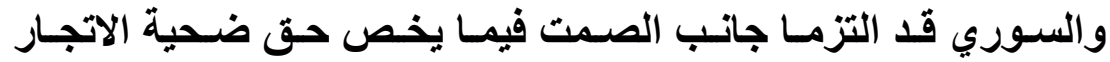

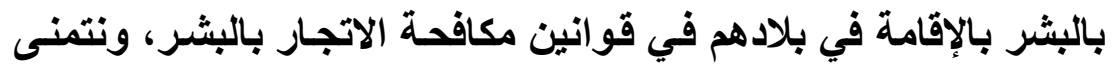
في هذا المجـال إعـادة النظر بهذه فئه القو انين واتخــاذ مسـلكاً مشــابهاً

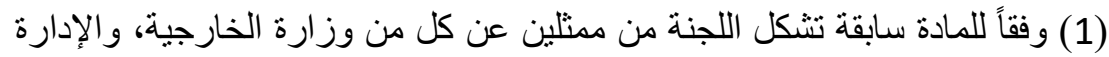

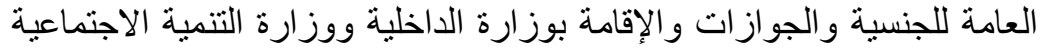

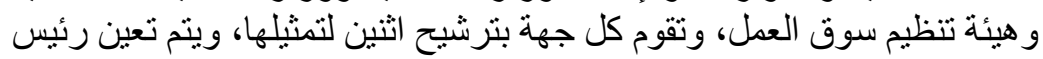

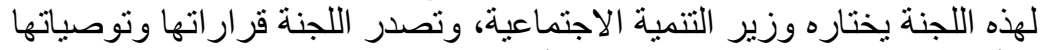

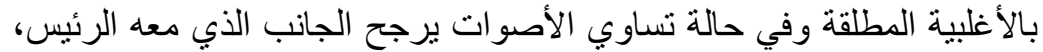

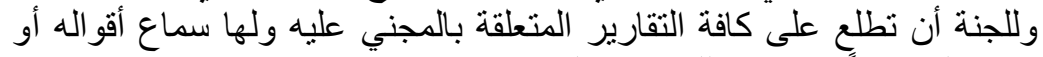

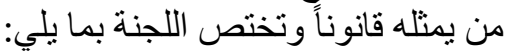
تنفيذ البند رقم (7) من المادة الخامسة من هذا لإنا القانون.

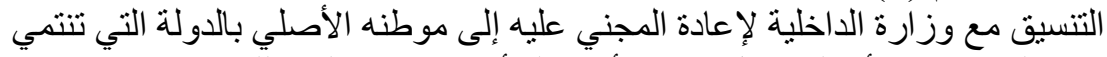

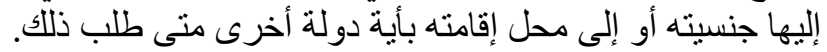
التوصية بما إذا كان يوجد ثُوة مقتضى لبقاء المجني عليه في المملكة وتوفيق أوضاعها

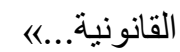

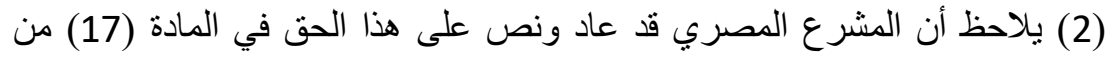

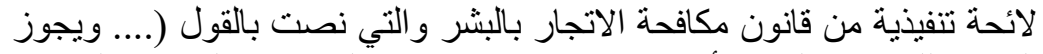

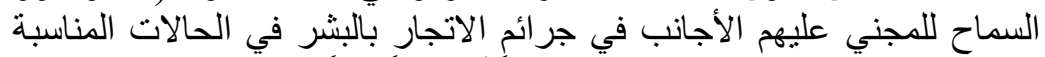

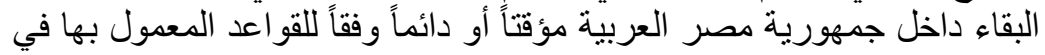

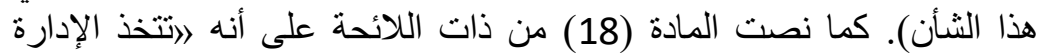

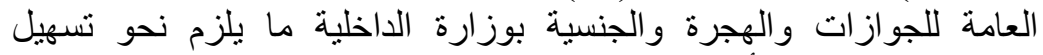

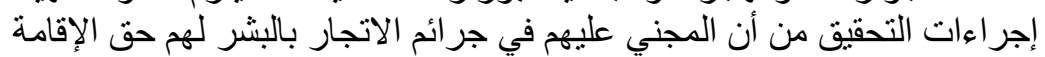
الدائمة في جمهورية مصر العربية.... 
للتشريعات التي أقرت هذا الحق هذا من جهة، ومن جهة ثانية نلاحظ

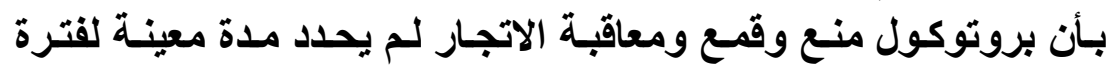

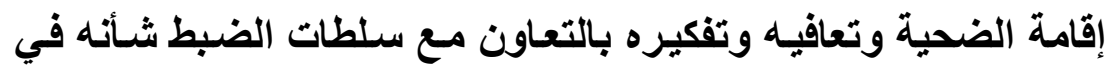

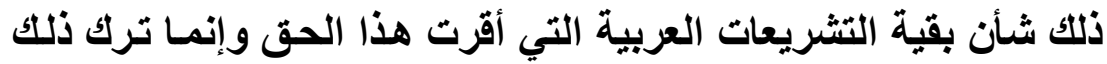

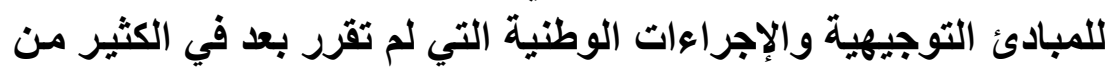

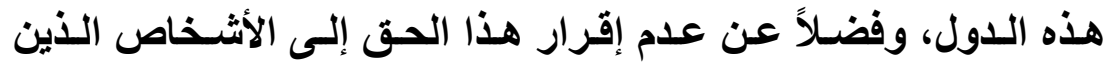

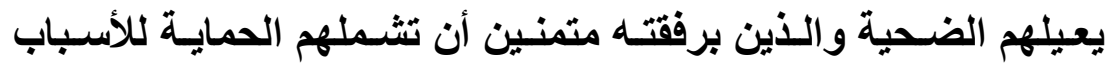
الوجدانية والإنسانية التي تتعلق بضحايا الاتجار بالبشر (1)

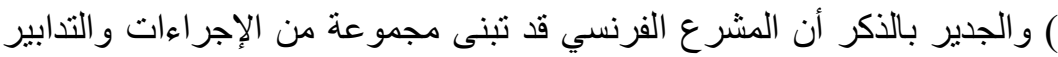

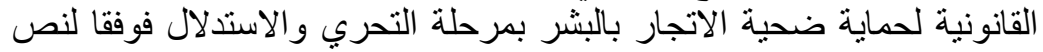

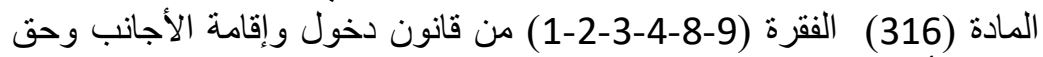

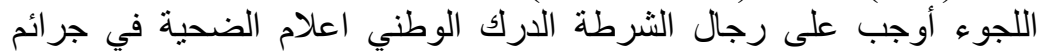

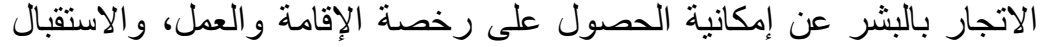

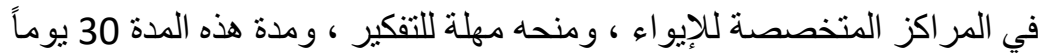

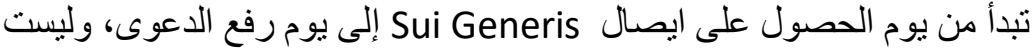

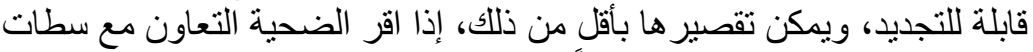

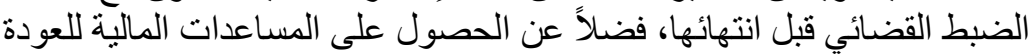
لوطنه، أو السفر لدولة أخرى.

Article R 316 - 1 "Le service de police ou de gendarmerie qui dispose d'éléments permettant de considérer qu'un étranger, victime d'une des infractions constitutives de la traite des êtres humains ou du proxênêtisme prêvues et rêprimêes par les articles 225-4 - 1 á 225-4-6 et 225-5á et225-10 du code pénal . est susceptible de porter plainte contre les auteurs de cette infraction ou de témoigner dans une procédure pénal contre une personne poursuivie pour une infraction ideentique, l'informe : 1 - De la possibilité d'admission au séjour et du droit á l'exercice d'une - 2- Des mesures d'accueil, d'hébergement et de protection prévues á la section 2 du présent chapitre; 3- Des droits mentionnés á l'article 53-1 du code de procédure pénale, notamment de la possibilité d'obtenir une aide juridique pour faire valoir ses droits. Le service de police ou de gendarmerie informe également l'étranger qu'il peut bénéficier d'un délai de réflexion de trente jours, dans les conditions prévues á 
L'artice R 316-2. du présent code, pour choisir de bénéficier ou non de la possibilié d'admission au séjour mentionnée au deuxiéme alinéa, Ces information sont données dans une langue que l'étranger comprend et dans des conditions de confidentialité permettant de le mettre en confiance et d'assurer sa protection.

Ces information peuvent être fourines complétées ou développées auprés des personnes intéressées par des organismes de droit privé á but non lucratif, spécialisés dans le soutien aux personnes prostituées ou victimes de la traite des êtres humains, dans l'aide aux migrants ou dans l'action sociale, désignés á cet effet par le ministre chargé de l'action sociale.

Article R 316-2 L' étranger á qui un service de police ou de gendamerie fournit les informations mentionnées á l'article R 316-1 et qui choisit de bénéficier du délai de un réflexion de trente jours mentionné au cinquiéme alinéa du même article se voit délivrer un récépissé de même durée par le préfét ou aparis, par le préfet de police, conformément aux dispositions du deuxiéme alinéa de l'article

R 311-4 Ce délai court acompter de La remise du récépissé pandant le délai de réflexion, aucune mesure d'éloignement ne peut étre prise á l'chcontre de l'étanger en application de L'article L 511-2 ni exécuté le délai de réflextion peut .

, á tout moment, être interrompu et le d'éloignement ne peut être prise á l'encontre de l'étranger en application de l'article L511-1 ni exécutée Le délai de réflexion peut, á tout moment, être interrompu et le récépissé retiré par le préft territorialement compétent, si l'étranger a, de sa prore initative, retiré un lien avec les auteurs des information mentionnées au premire alinéa de l'article R 316-140 du présent code, ou si sa présence constitue une menace grave pour l'ordre public.

Article R 311-4 ' II est remis á tout étranger admis á souscrire une demande de premiére délivrance ou de renouvellement de titre de séjour un récépissé qui autorise la présence de l'intéressé sur le territoire pour la durée qu'il 
précise, Ce récépissé est reêtu de la singature de l'agent compétent ainsi que du timbre du service chargé. en vertu de l'article R 311-10, de l'instruction de la demande. Un récépissé peut également être remis á l'étranger qui demande á bénéficier du délai de réflexion prévu aux articles R. 316-1 et R. 316-2 et qui est signalé comme tel par un service de police ou de gendamerie .

Article R 316-3 Une carte de séjour temporaire portant la mention "vie privée et familiale d'une durée minimale de six mois est délivrée par le préfet territorialement compétent á l'étranger qui satisfait aux conditons définies á l'article $L$. 316-1 et qui a rompu tout lien avec les auteurs présumés des infractions mentionnées á cet article .

La même carte de séjour temporaire peut également être délivrée á un mineur âgé d'au moins seize ans, remplissant les conditions mentionnées au présent article et qui déclare vouloir exercer une activité professionnelle salariée ou suivre une formation professionnelle.

La demande de carte de séjour temporaire est accompagnée du récépissé du dépôt de plainte de l'étranger ou fait référence á la procédure pénale comprtant son témoignge .

La carte de séjour temporaire est renouvelable pendant toute la durée de la procédure pénale mentionnée á l'alinéa précédent sous réseve que les conditions prévues pour sa délivrance continuent d'être satisfaites .

Article R 316-8 L'étranger titulaire d'une carte de séjour temporaire "vie privée et familiale délivrée dans les conditions prévues á l'article R 316-3, bénéficie de l'accés aux dispositifs d'accueil, d'hébergement, de logement temporaire et de veille sociale pour les personnes défavorisées mentionnés mentionnés au $8^{\circ}$ du I de l'article L 312-1 et á l'article L. 345-2 du code de l'action sociale et des familles, et notamment aux centres d'hébergement et de réinsertion sociale mentionnés au dernier alinéa de l'aricle L. 345- I du même code ...

Article R 311-9 ' L' étranger titulaire d'une carte de séjour temporaire 'vie privée et familile ' délivrée dans les 
خامساً: توفير الذدمات الأساسية لضحية الاتجار بالبشر.

تتبع الكثير من الدول عند إصدار قو انين الاتجار بالبشر ولوائح

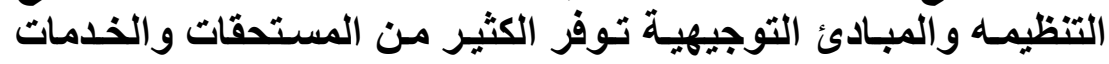

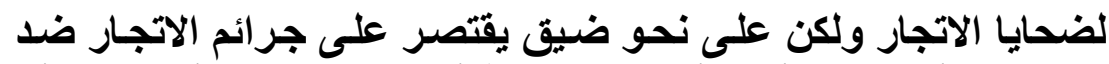

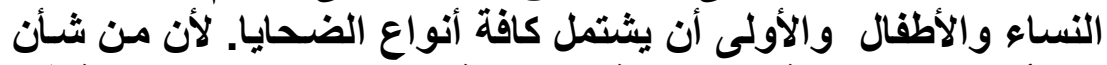

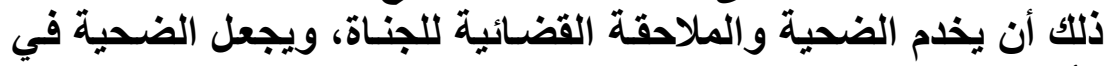

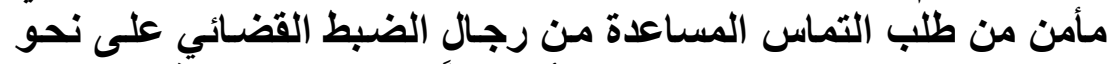

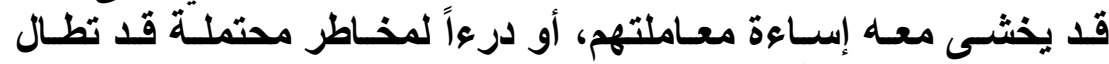

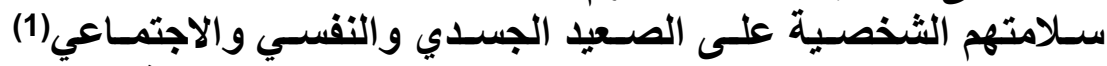

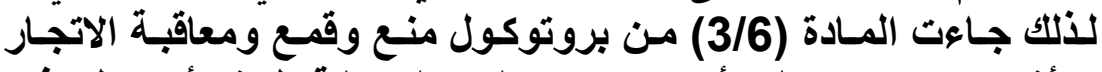

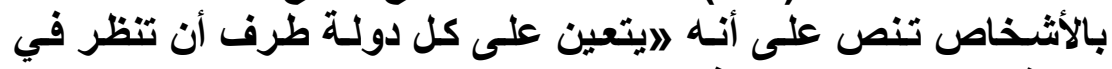

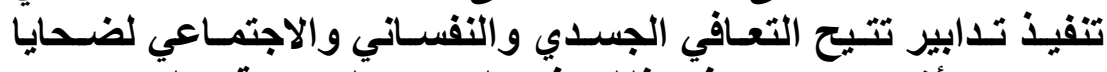

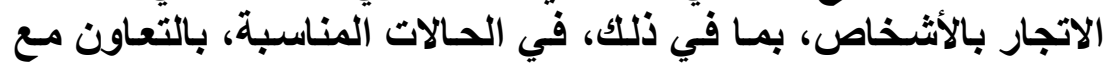

conditions prévues á l'article R 316-3 qui souhaite retourner dans son pays d'origine ou se rendre dans un autre pays peut bénéficier du dispositif d'aide au retour fnancé par l'Office francais de l'immigration et de l'intégration.

ونجد أن قانون حماية حقوق ضحايا الاتجار بالبشر الأمريكي لعام 2000

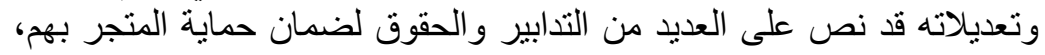

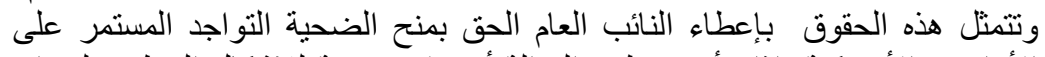

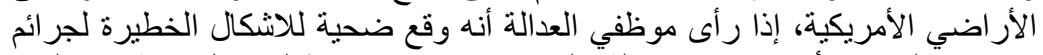

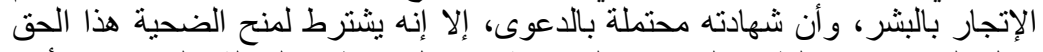

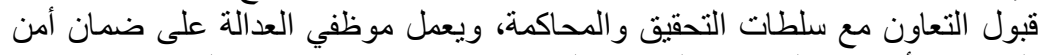

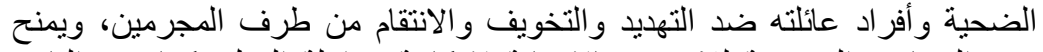

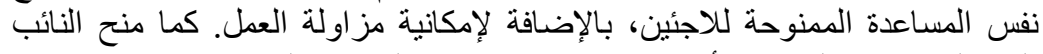

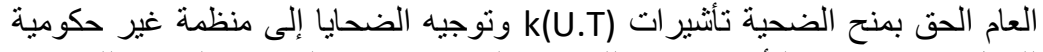

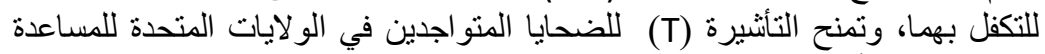

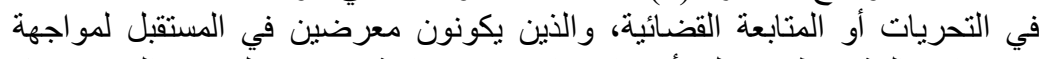

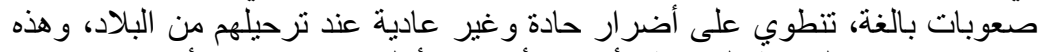

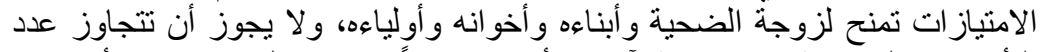

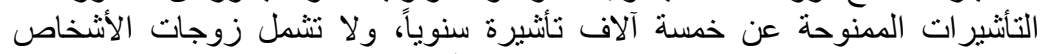

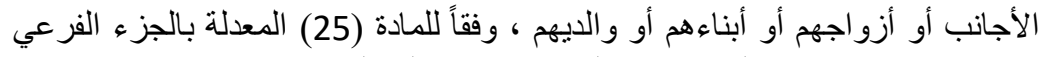

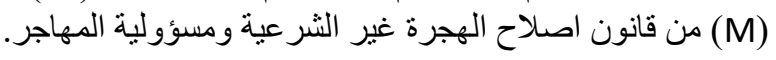

(1) Kelly E. Hyland protecting Human Victime of Trafficking, An American Framework, 2009, p29 -35.

switzer land: Global commission on international migration. 2004. P.82 
منظمات غير حكومية وسائر المنظمات ذات الصلة وغيرها من عناصر

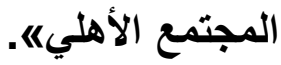

ومن صور هذه التدابير، أن تتاح للضحية إمكانية توفير المسـاعدة

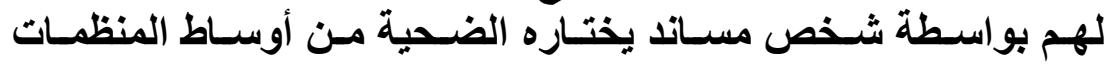

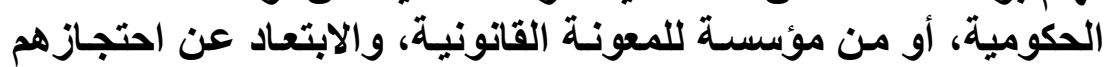

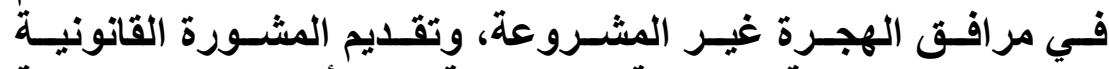

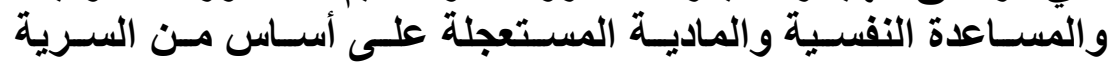

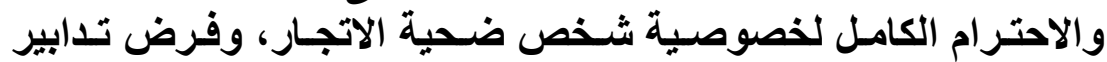

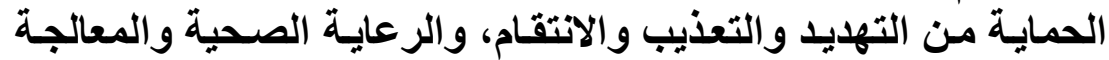
الطبية اللازمة وإجراء الاختبارات السرية للأمراض السارية والئية والمعدية

وخاصة الأمراض الجنسية، مي ضرورة أن تثنمل هذه التدابير أيضاً الأثخاص الذين يعولهم الضحية ويرافقونه (1)

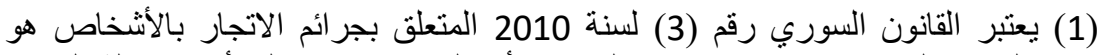

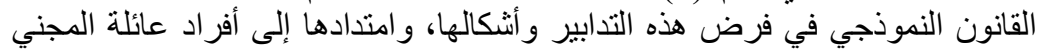

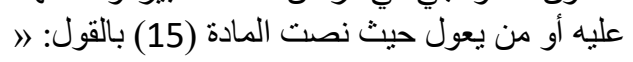

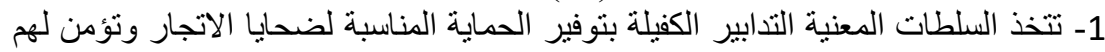

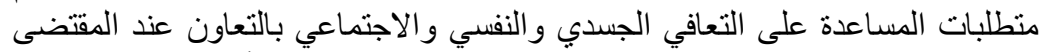

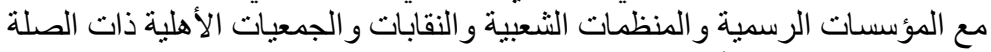

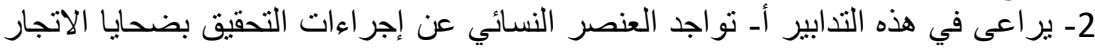

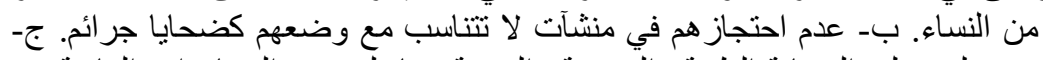

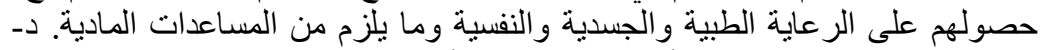

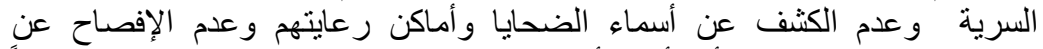

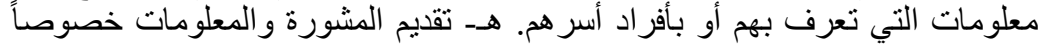
فيما يتعلق بحقوقهم القانونية وبلغة مفهومة للضحيةنان. 


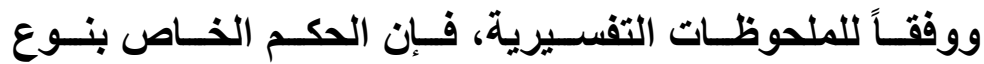

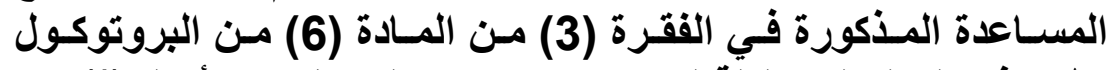

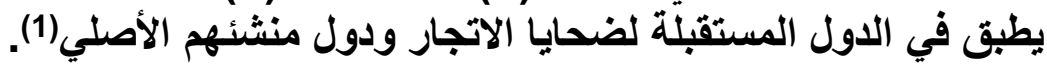
ونـذكر هنـا بوجوب فرض هذه التدابير في أبكر وقت ممكن

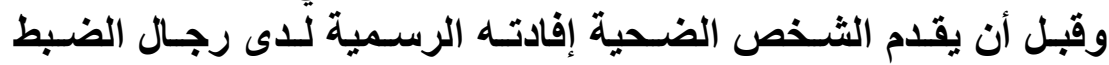
(2) (القضائي أن

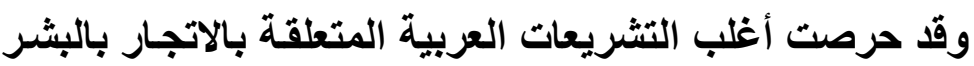

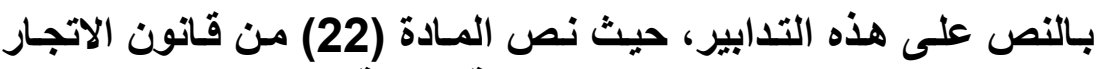

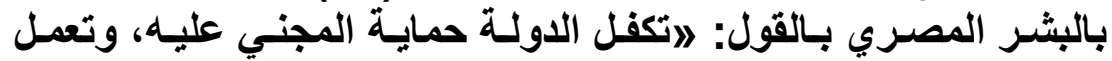

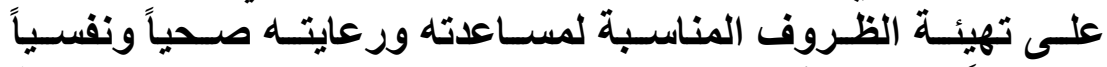

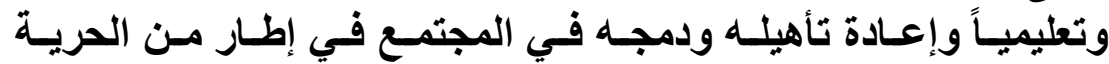

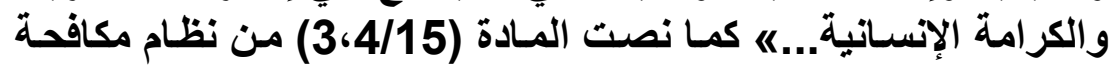

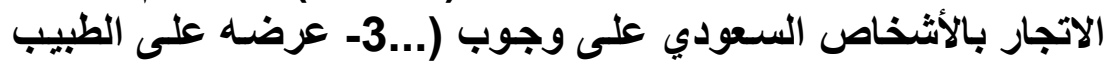

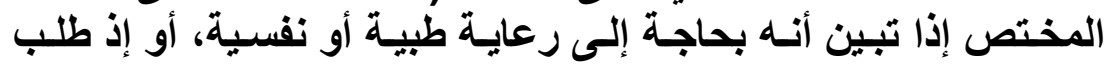

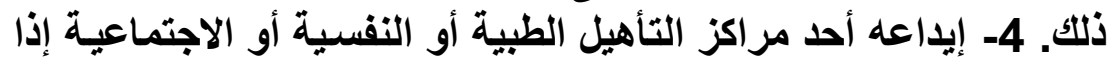

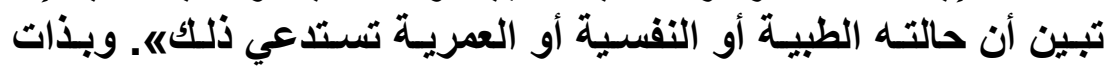

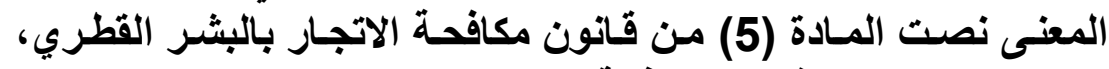
والمادة (5/ب) من قانون مكافحة الاتجار بالبشر العمان ماندي.

(1) الفقرة (71) الملحوظات التفسيرية (A/55/383/Add.1) من وثائق الأمم المتحدة.

(2) Akers (T) \& Lanier,(m), Epidemiological Criminology: coming full circle. American Journal of public Health, 2009, pp.99, phinney (A), Trafficking of women and children for sexual exploitation in the America's. [o] Available: //www.planetwire.org/wrop/Files. Fcgi/2369-trafficking-papars.ht Assessed 25/03/2008. 


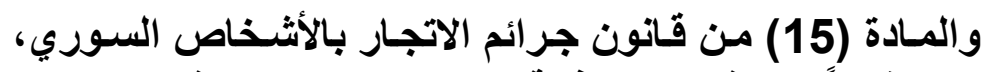

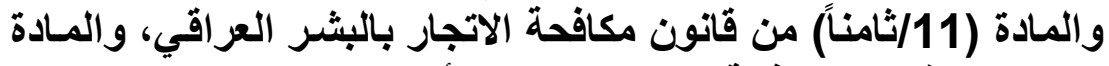

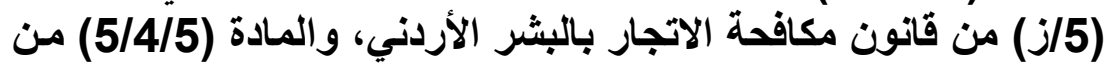

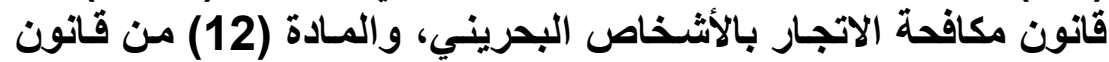
مكافحة الاتجار بالبشر الكويتي رقم (91) للنية (2013).

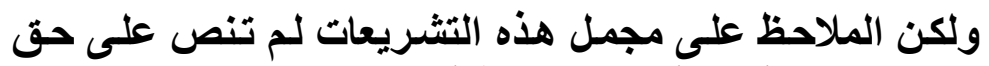

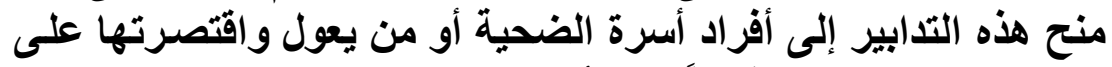

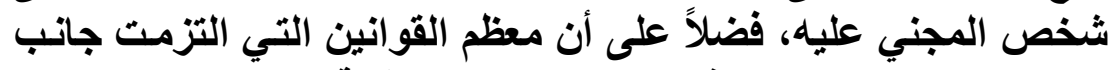

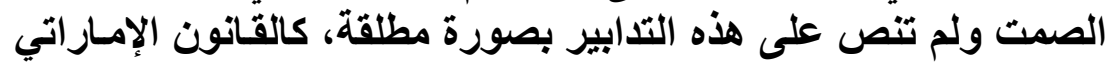

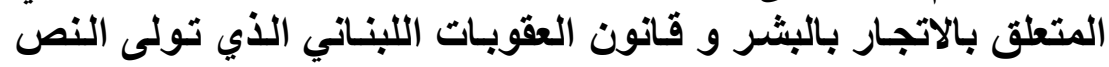

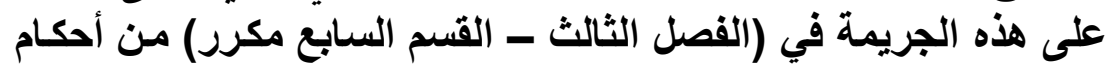
قانون العقوبات، متمنين في هذا المجال أن تضمنه في أحكام قوانينها. 


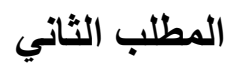

حقوق الضحية في مرحلة التحقيق الابتدائي

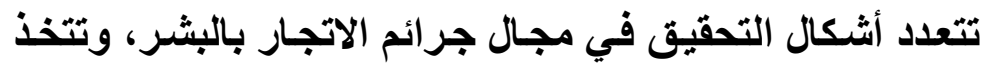

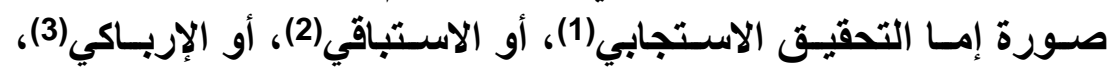

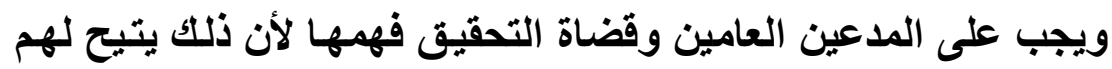

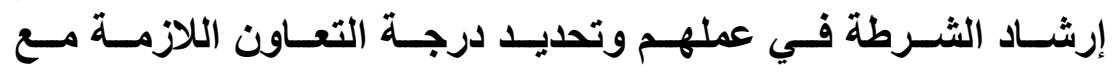

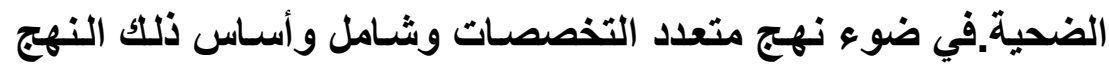

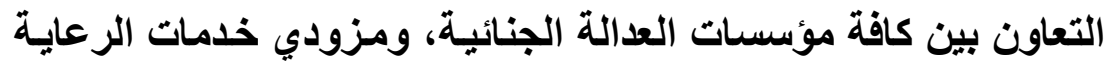

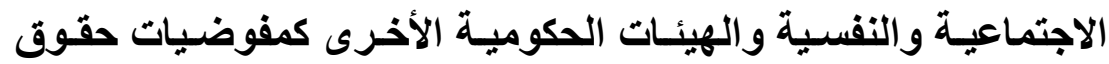

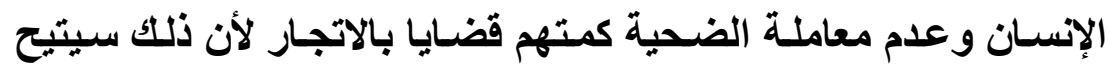

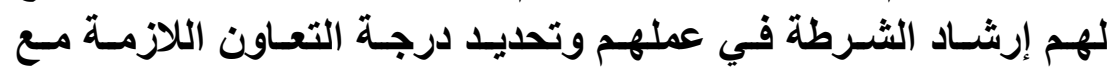

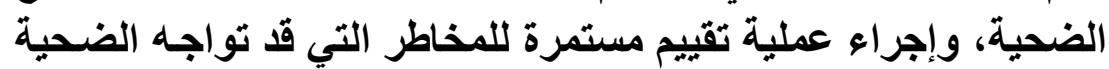

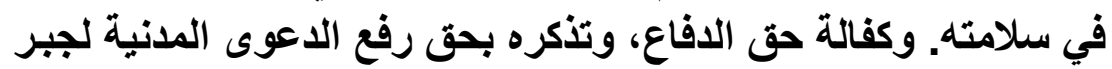

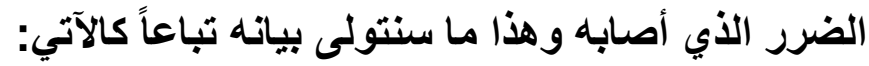
أولاً: حق الضحية بالمشاركة في إجراءات التحقيق الابتدائي.

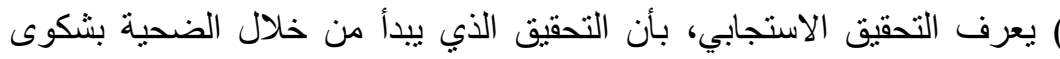

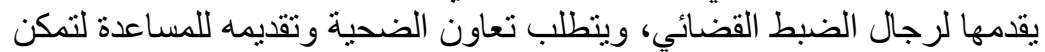

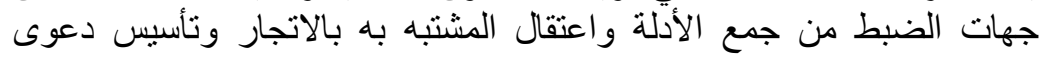

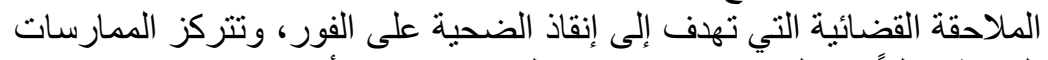

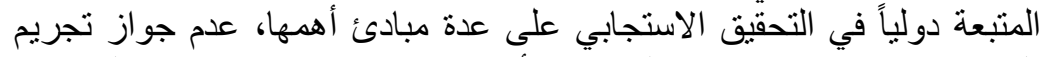

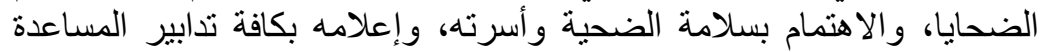

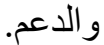
أما التحقيقات الاستباقية، تبدأ من خلال العمليات الاستخبارية التي يجريها

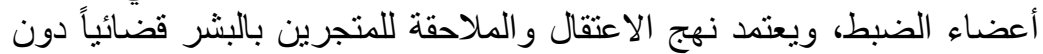

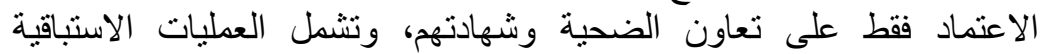

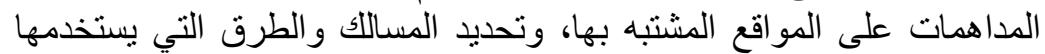

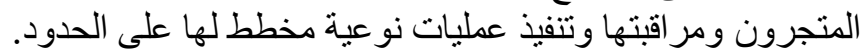

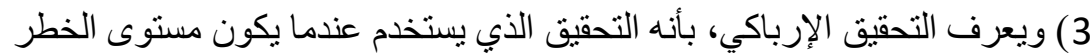

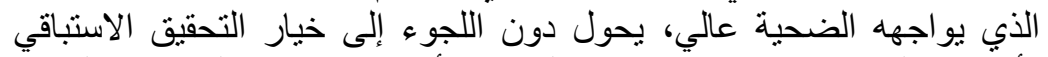

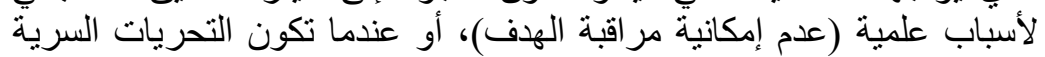
غير كافية. 
يجب على سـلطات التحقيـق الابتـائي أن تتيح الفرصـة أمسام

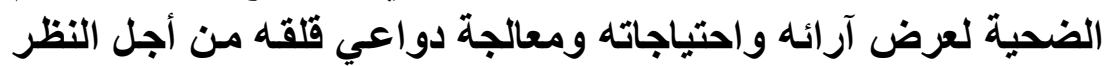

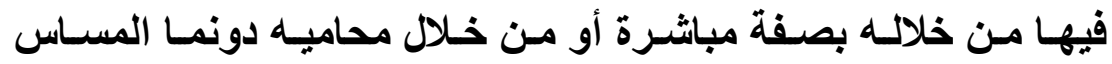
بحقوق الدفاع(1).

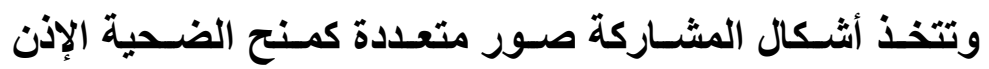

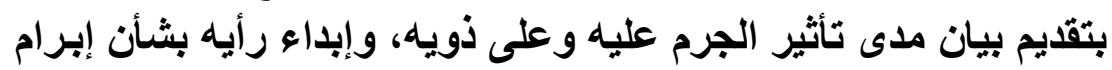
اتفاق على الاعتراف بجرم مقابل تذفيف العقوبة على دلى الجاني.

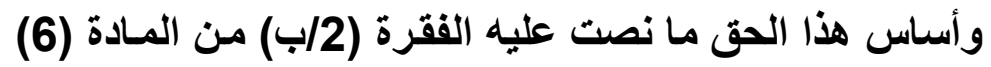

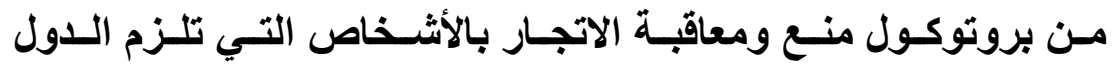

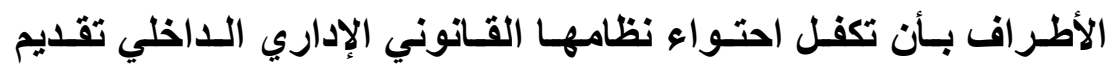

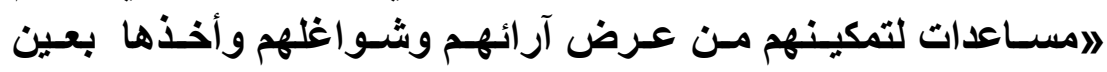

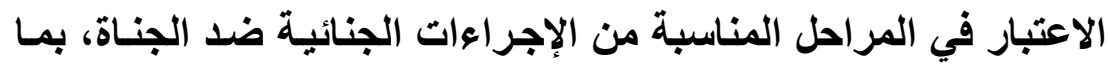

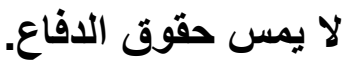

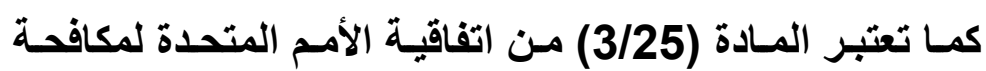

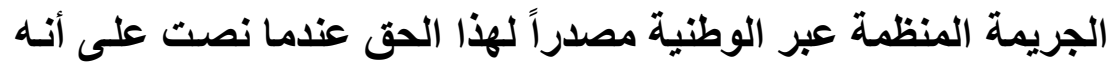

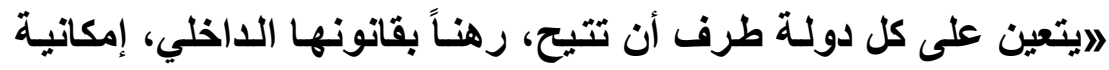

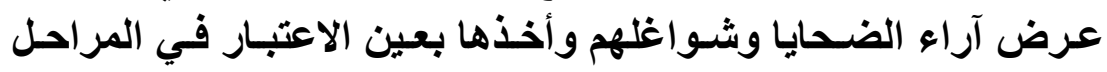

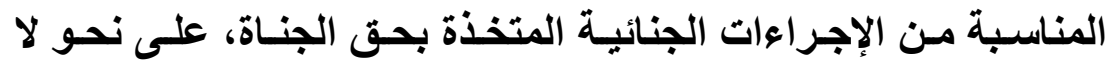
يمس بحقوق الافاعه الاجهرات

وهذا ما نصت عليه المـادة (23/د) من قانون مكافحة الاتجار

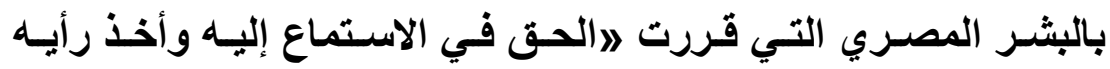

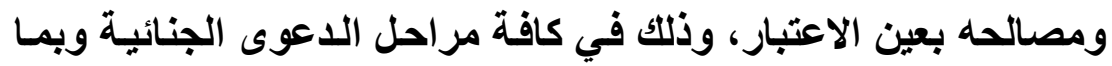

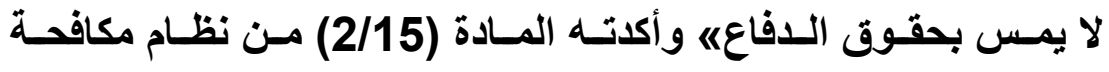

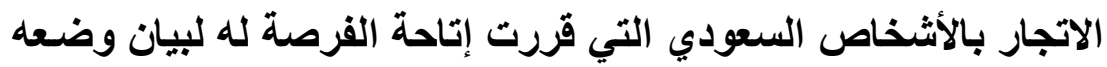

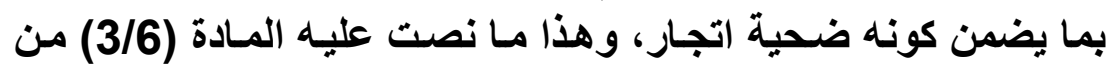

(1) united nations Development program, Romania law Enforcement Best practice manual for fiahting Against Trafficking of Human Beings, Executive Summery. USAID. 2.12.p.10 CHECK 
قانون مكافحة الاتجار بالبشر القطري، والمادة (5/5أ) من قانون مكافحة

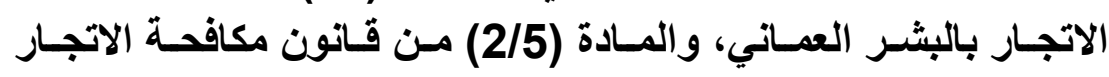

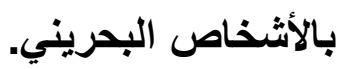

ويلاحظ أن العديد من التثريعات العربية بمجال مكافحة الاتجار

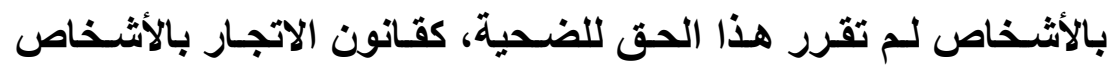

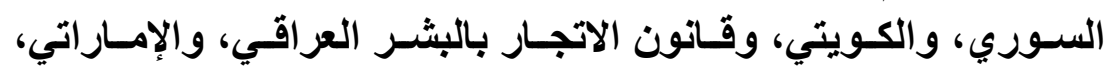

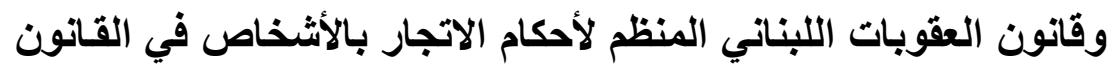

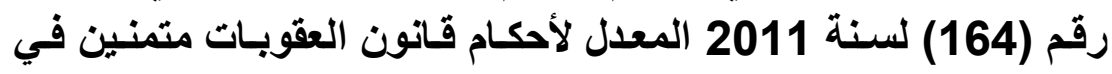

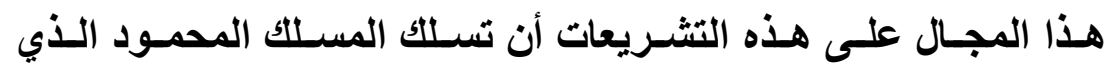

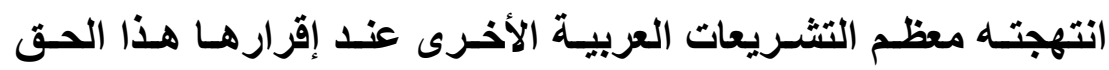

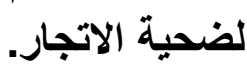

\section{ثثانياً: حق الضحية في رفع الاعوى المدنية}

يجب أن يكون لضحية الاتجار بالأثخاص الحق في رفع دعوى لئي

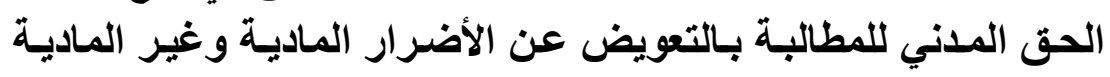

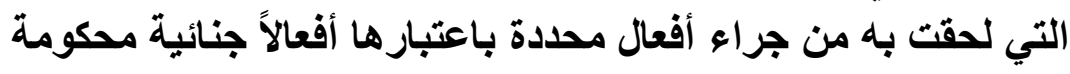




\section{بموجب قوانين الاتجار بالبشر (1).}

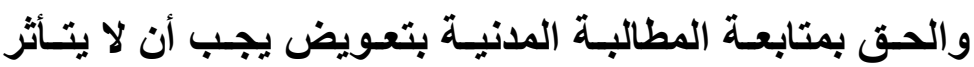

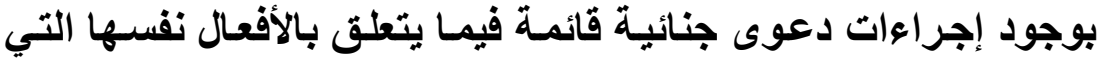

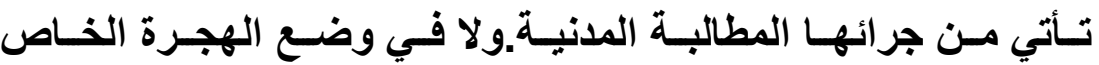

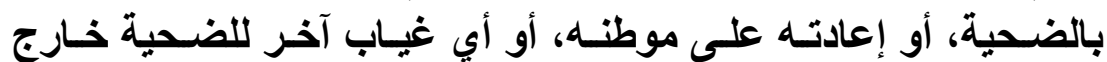

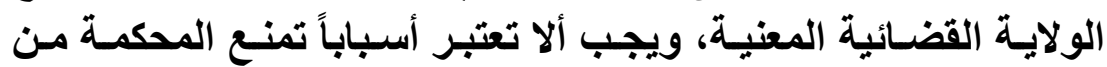
إصدار أمر بدفع تعويض(2) - 2)

وإلى جانب هذا الحق يجوز للضحية مباشرة هذه الإجراءات

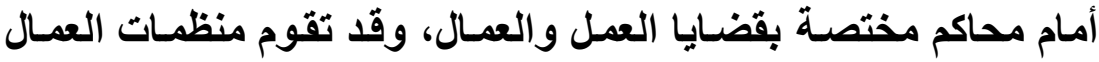

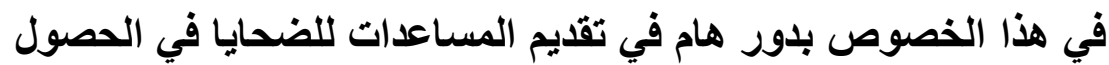

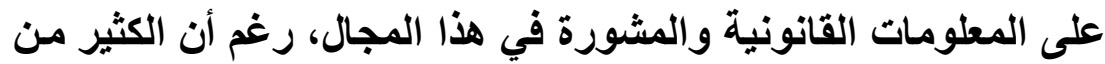

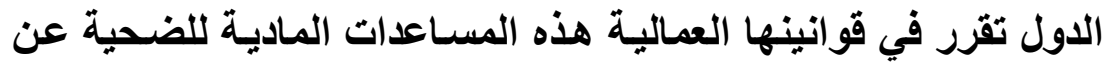
طريق النص في قوانين العمل على إعفاء الدعاوى العمالية من الرسوم

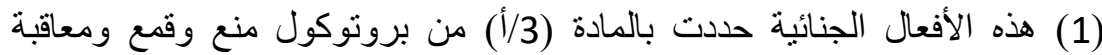

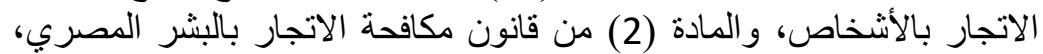

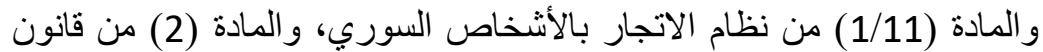

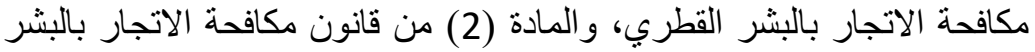

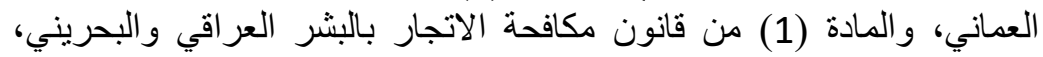

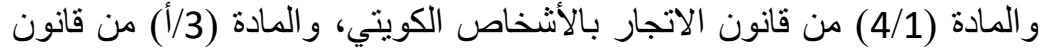

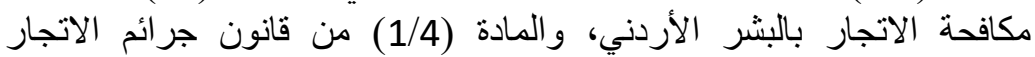

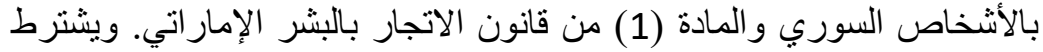

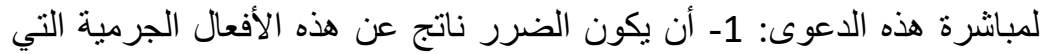

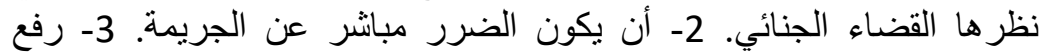

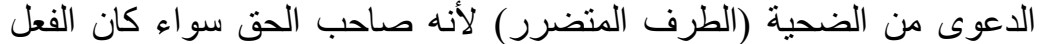
جناية أو جنحة أو مخالفة،

Van den Hoven, (A) \& maree, (A): Victimization risk factors, repeat Victimization and victim profiling. In Davis, L \& Snyman, R.victimology in south A frica. Van shaik Publishers 2005.

(2) د. هاني السبكي، عمليات الاتجار بالبشر (دراسة في ضوء الثريعة الإسلامية

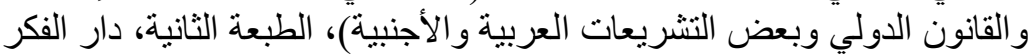

$$
\text { العربي، الإسكندرية، 201، ص97. }
$$




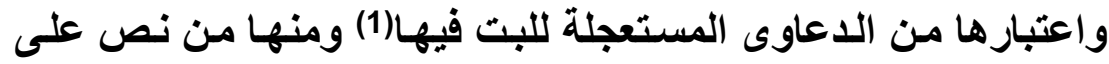

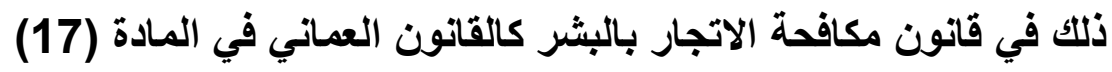

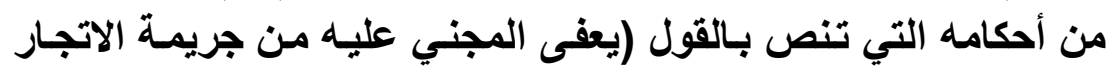

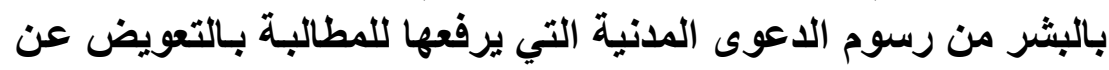
الضرر الناجم عن استغلاله في جريمة الاتجار بالبشر).

ولكـن ينبفـي لأي دعـوى مدنيـة أو عماليـة أن تتبـع مســار

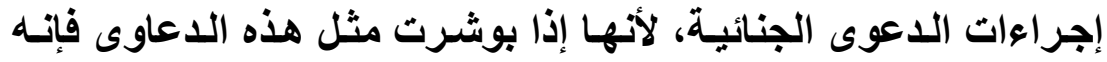

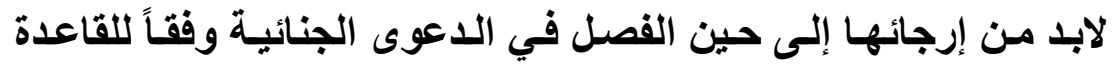
الجنائية المعروفة إنأن الجنائي يعقل المدني(2).

وبـالرجوع لأحكـام البروتوكـول منـع وقـــع ومعاقبـة الاتجــار

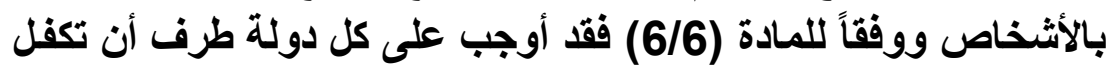

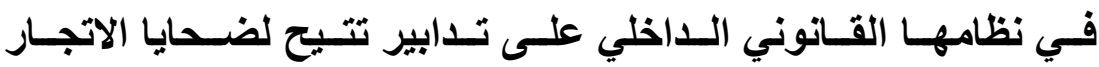

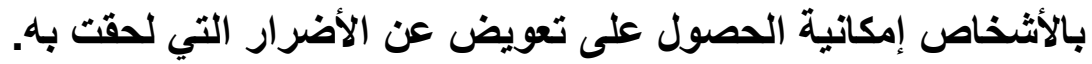

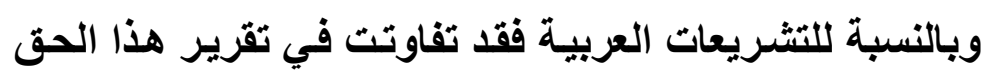

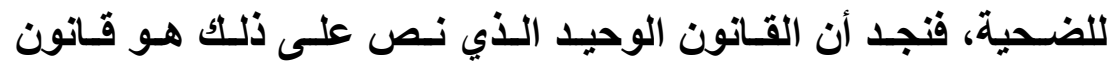

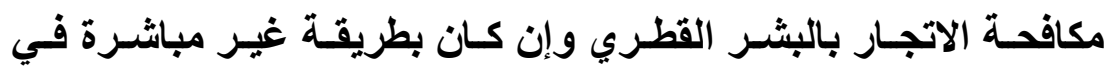

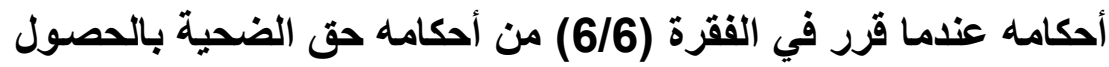

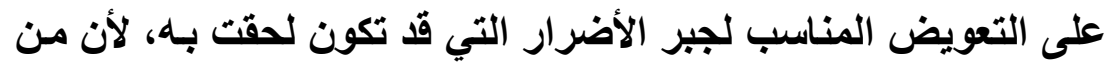

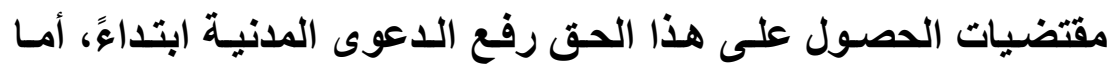

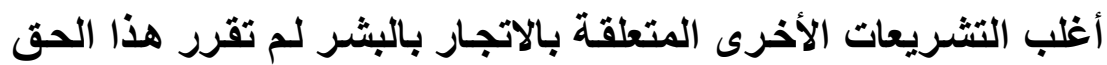

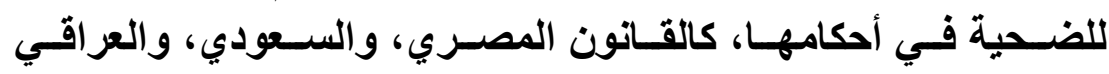

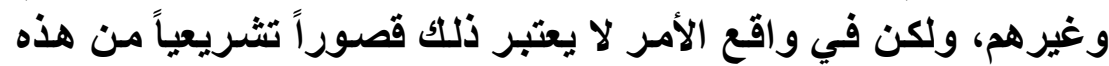

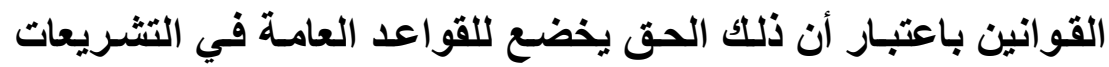

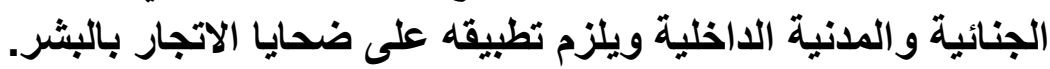

(1) د. أحمد لطفي السيد مرعي، إستراتيجية مكافحة جرائم الاتجار بالبشر، دراسة

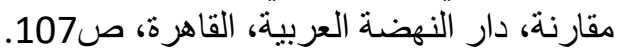
(2) د. كامل السعيد، شرح الأحكام العامة في قانون العقوبات، دراسة استة مقارنة، الطبعة

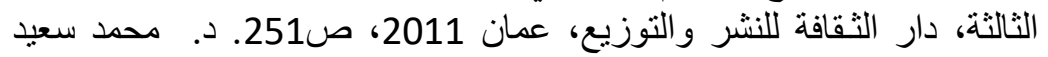

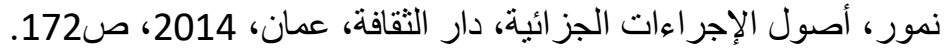


ثناثاً: الالتزام بالامتناع عن ملاحقة الضحية قضائياً

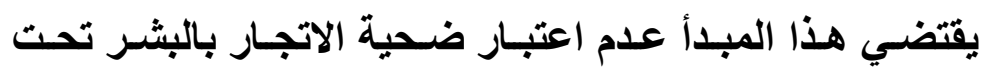

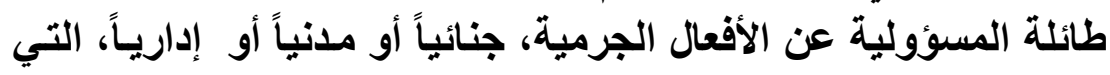

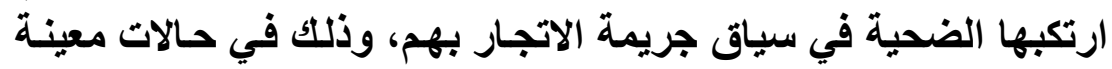

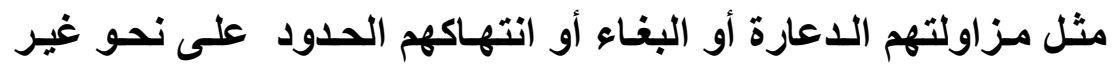

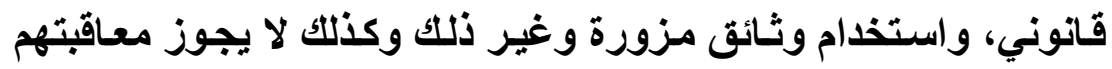
وحجزهم وتغريهم في إطار القانون الوطني.

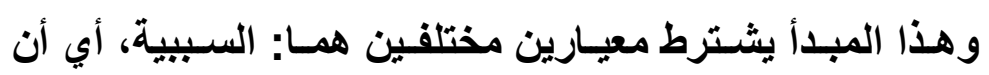

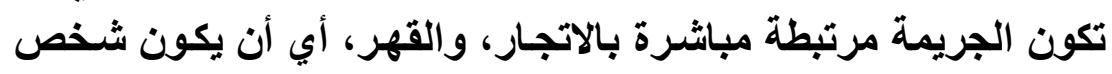
الضحية أرغم على ارتكاب الأفعال الجرمية (1).

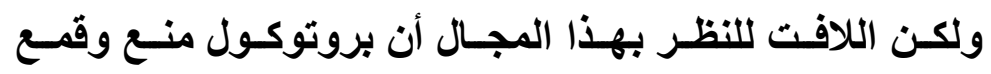

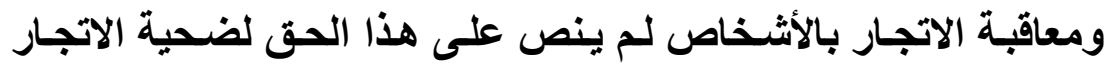
وترك الأمر اختيارياً للقوانين الوطنية لمكافحة الاتجار بالأثخاص.

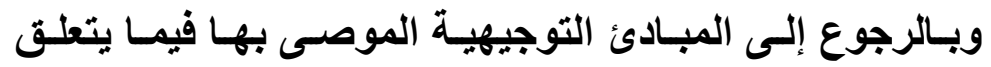

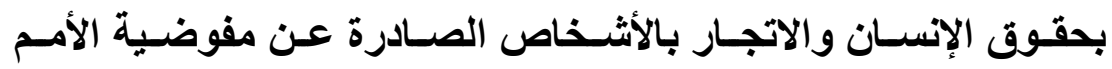

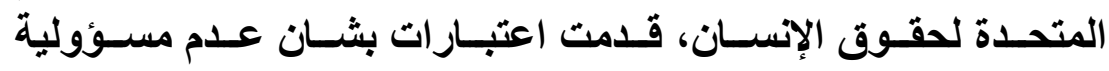

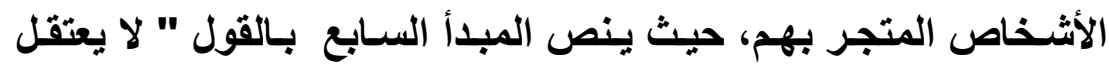

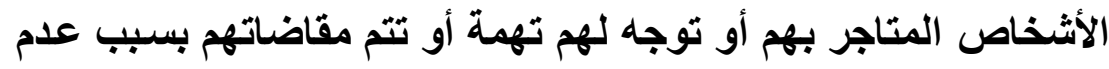

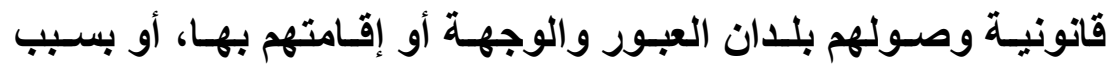

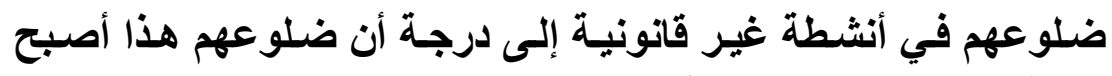

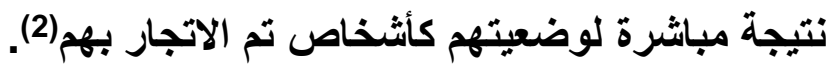

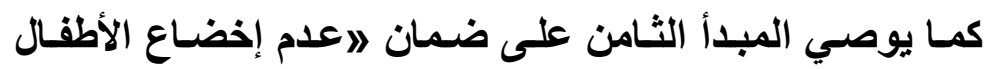

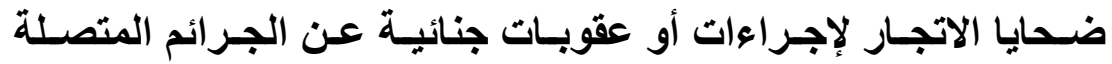

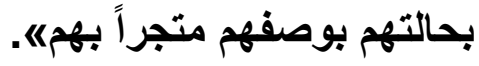

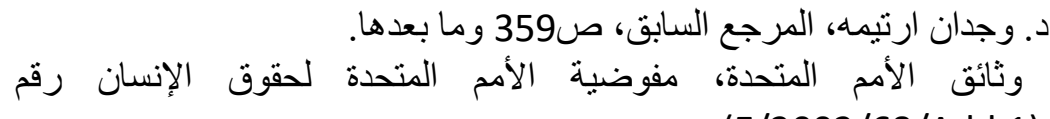

(E/2002/68/Add.1) 
ونصت على هذا المبدأ المادة (26) من اتفاقية مجلس أوروبـا

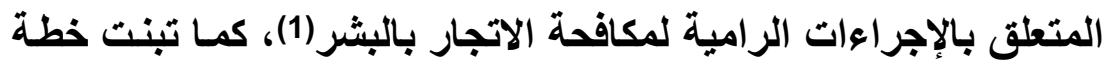

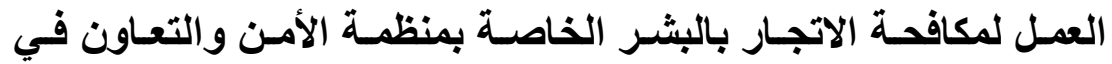

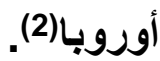

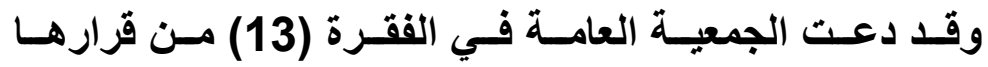

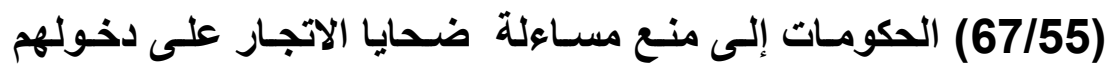

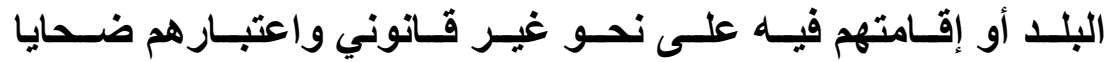

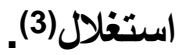

أمسا التثريعات العربيـة فقد تفاوتت بتقرير هذا الحق لضحية

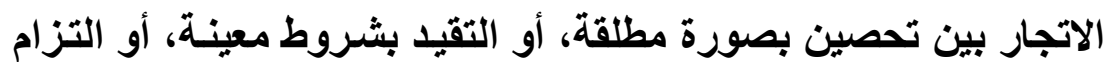

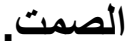

فنجد أن المشرع المصري قد قرر هذا الحق لضحية الاتجـار

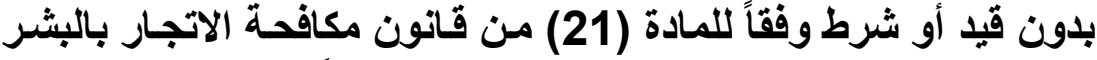

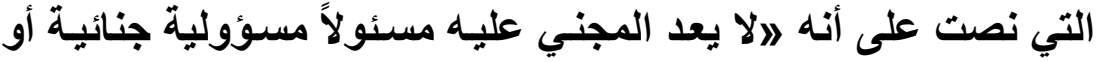

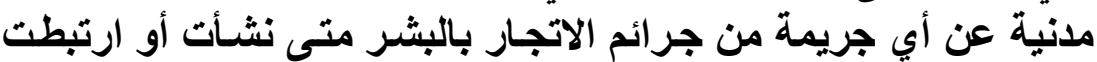

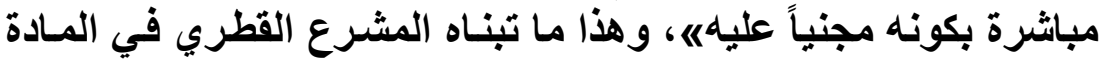

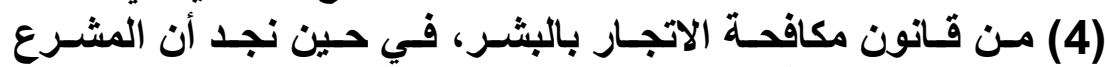

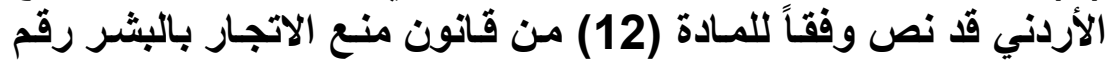

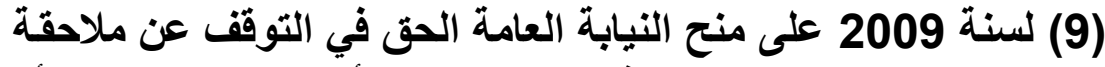

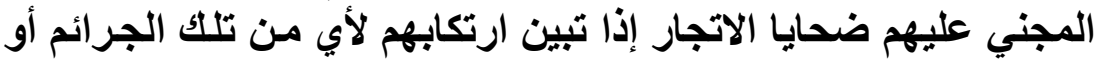

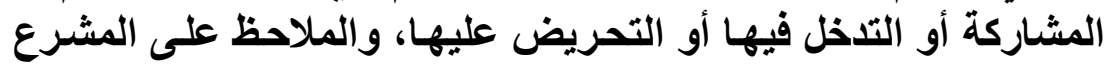

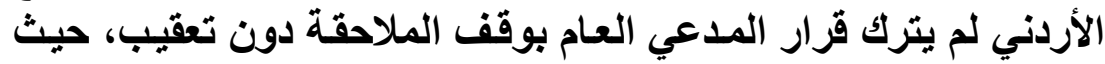

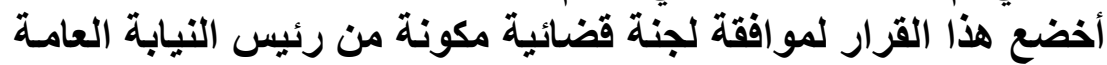

(1) تنص المادة (26) من الاتفاقية بقولها إعلى كل دولة طرف أن تعمل، وفقاً

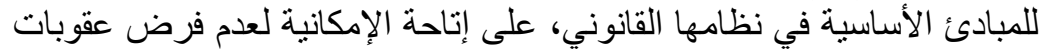

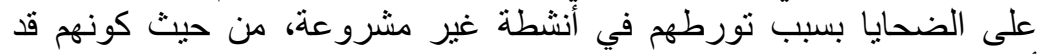

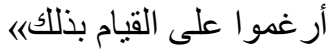

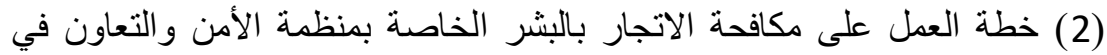
أوربا المقرر (557/Rev، 7 تموز اليعليوليو 2005).

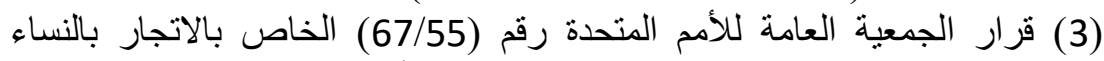
و الفتيات، الصادر بتاريخ 2000/4/12، وثائق الأمم المتحدة لكائة 
رئيسـاً، وقاضـيين مـن محكمـة التمييـز يختار هـــــــــس المجلس

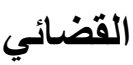

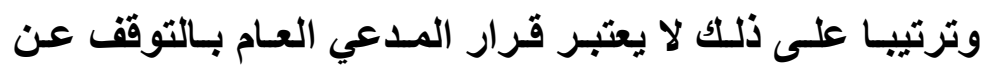

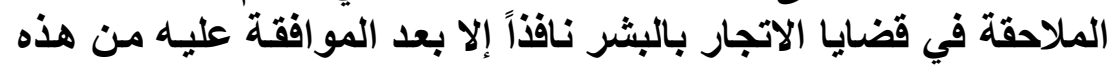

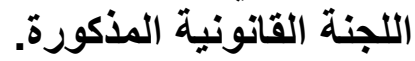

وحسناً فعل التوجه القانوني الذي يذهب إلى إعفاء الضحية من إنها

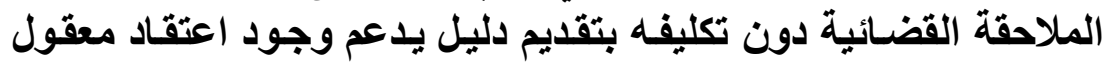

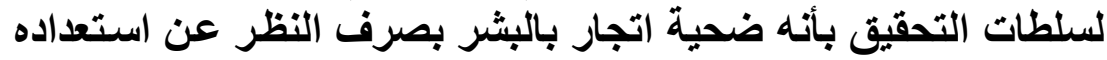

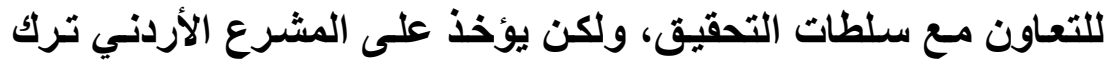

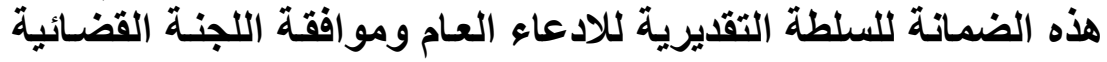

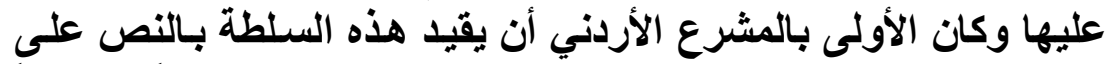

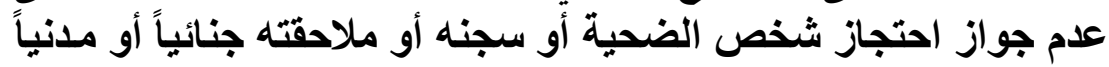

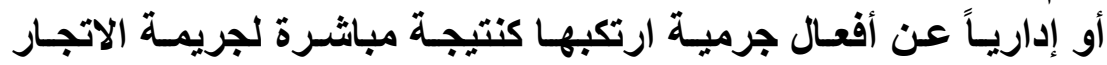

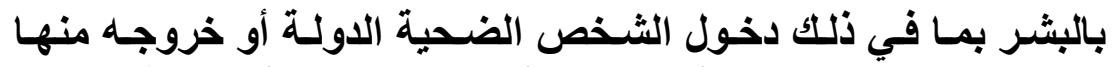

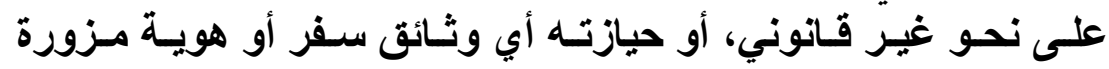

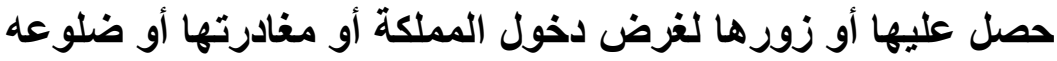




\section{في أنثطة غير مشروعة أرغم على القيام بها(1).}

في حين نجد أن المنظم السعودي ووفقاً لنظام الاتجار بالبشر قد التزم

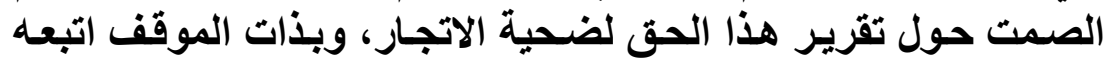

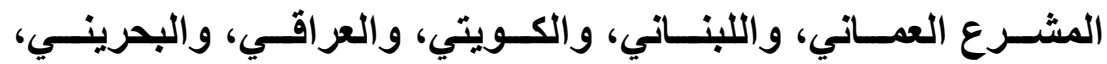

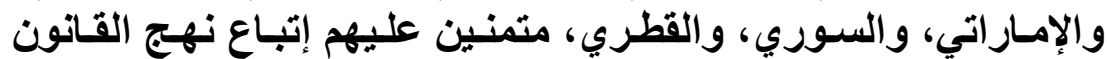

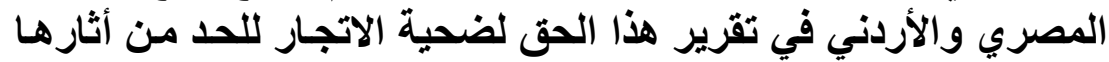

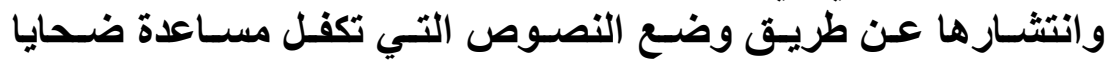
الاتجار بالبشر وحماية حقوقهم.

رابعاً: حق الضحية في التمثيل القانوني.

يعتبر حق الدفاع من الحقوق الأصلية المقلسة المقررة لضحية

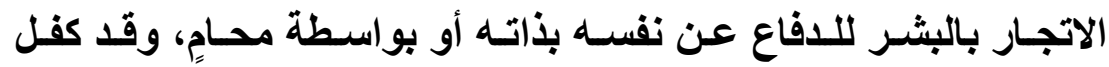

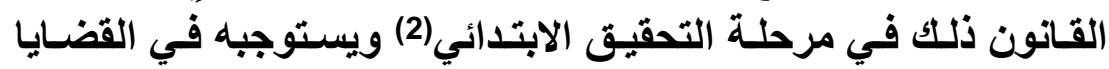

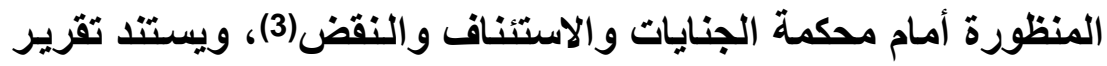

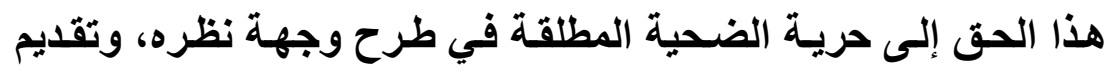

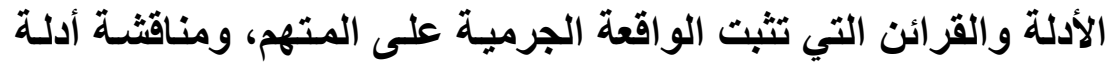

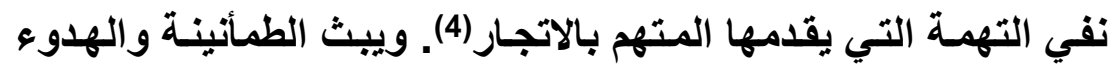
بنفس الضحية، ويقدم له المساندة القانونية، ويرتب دفاعه في مواجهة

(1) و هذا ما تبنته بعثة الأمم المتحدة المؤقتة في كوسوفو في البند التنظيمي رقم (1)/2000 بشأن

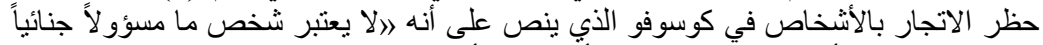

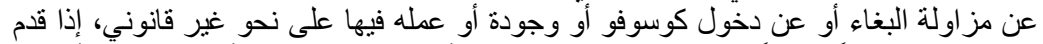

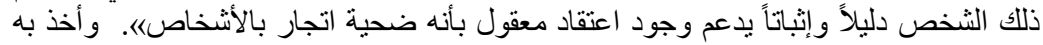

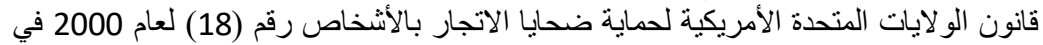

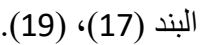

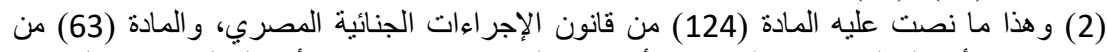

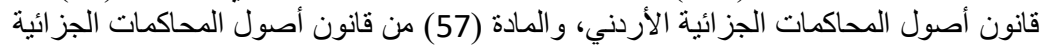

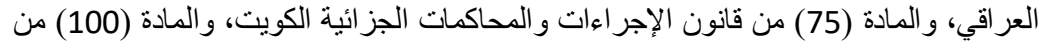
الإجر اءات الجز ائية الجز ائرية.

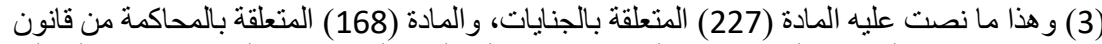

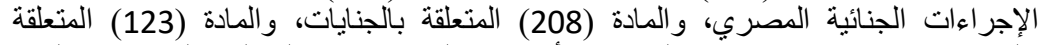

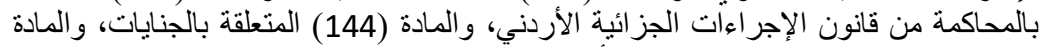

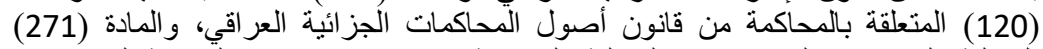

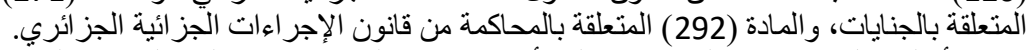

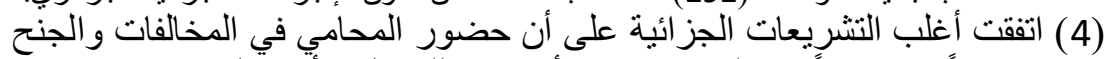

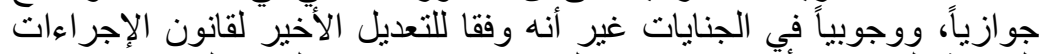

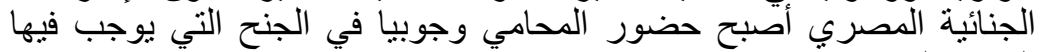
القانون الحبس. 
المتهج(1) وينبه إلى حقوقه وواجباته، ويجعل المحامي رقيباً على سير

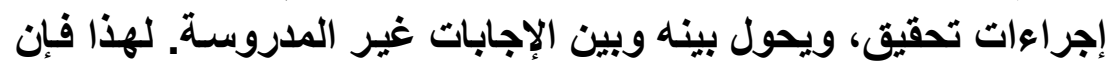

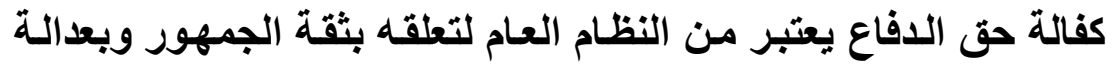

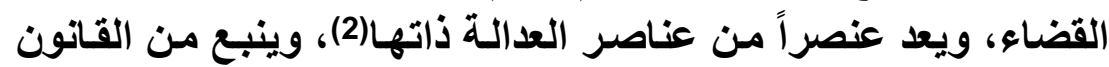

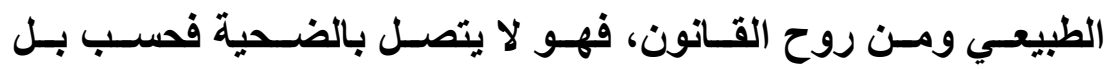
بالمشروعية بذاتها(3).

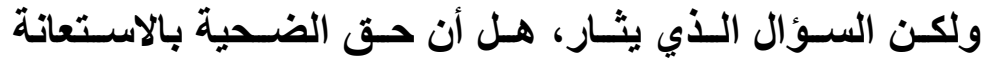

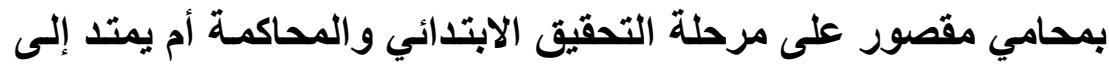
مرحلة الاستدلال في جريمة الاتجار بالبشر؟ الابتر

نجد أن غالبية التشريعات الجزائية العربية قد التزمت الصمت بـائل

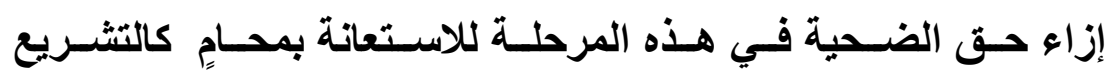

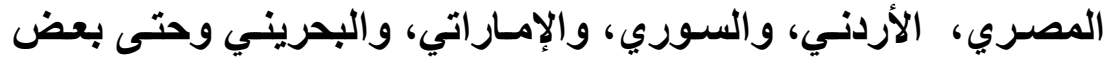

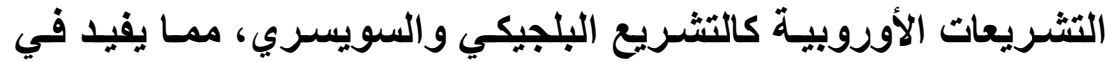

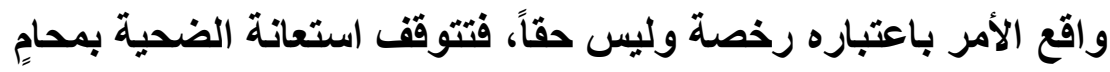

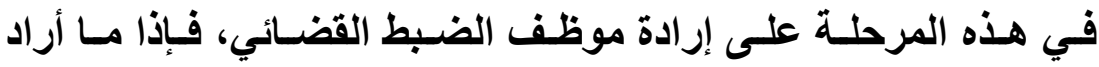

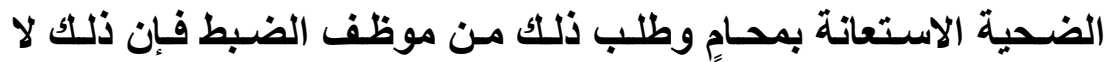

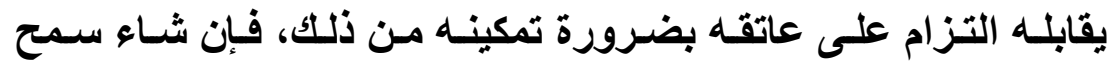

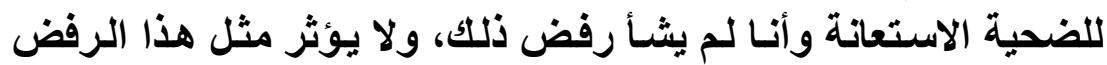

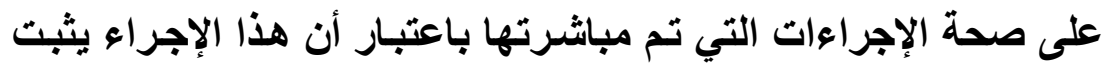

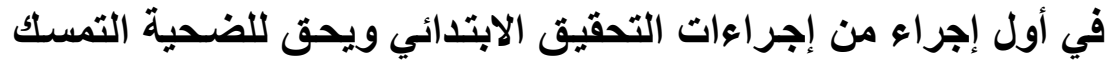
بحضور محاميه أثناء التحقيق(4).

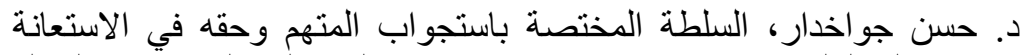

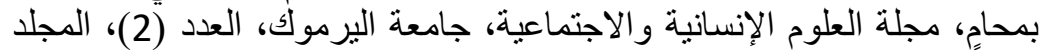

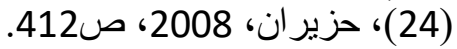

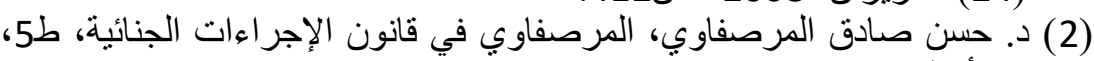

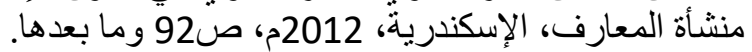
(3) د. سامي الحسيني، حق المتهم في الاستعانة بمحادٍ، مجلة المحامون السورية،

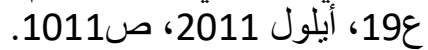

(4) سيف إبراهيم مصاروة، حق الاستعانة بمحامٍ في مرحلة في مرحلة التحقيق

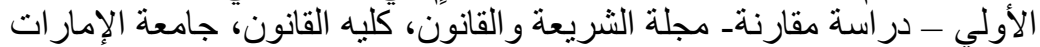

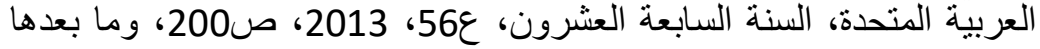




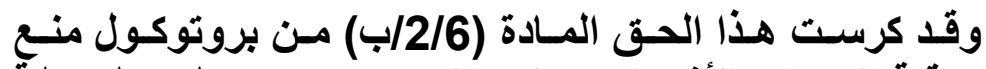

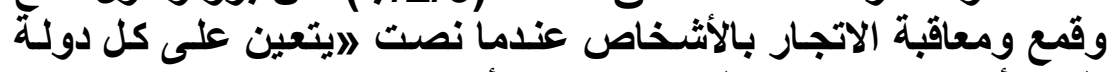

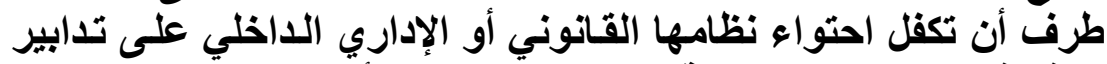

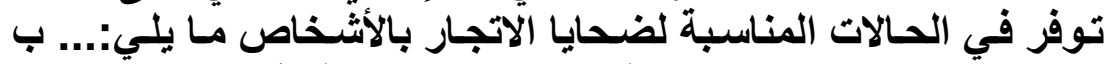

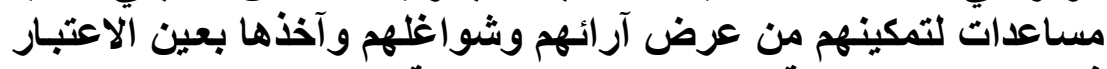

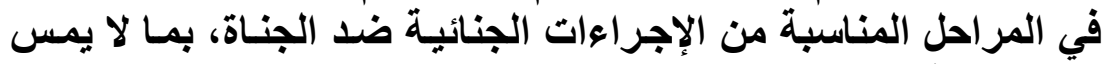
بحقوق الدفاعه.

وهذا ما أقرته معظم التشريعات العربية، إلا أن بعضها قد أقرته

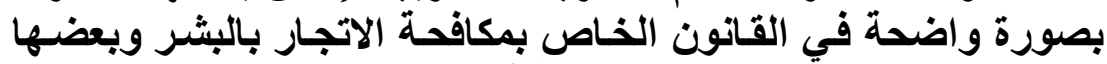

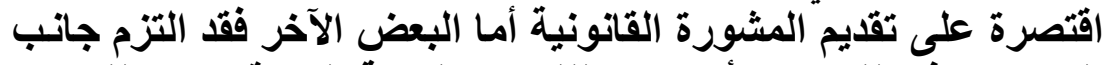

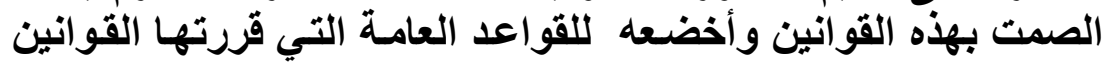

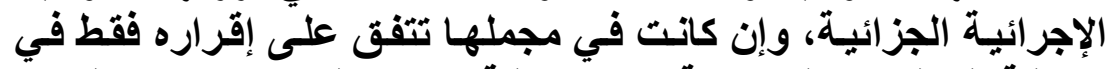

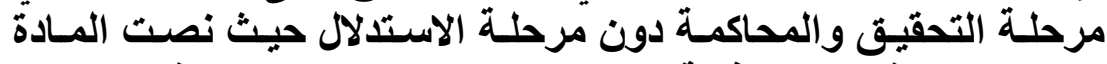

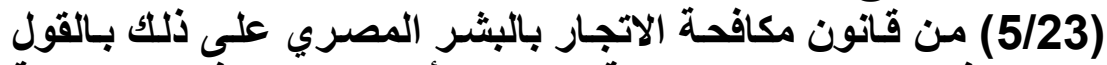

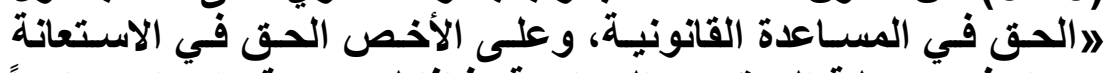

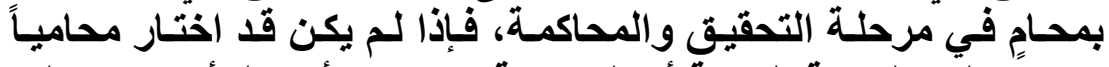

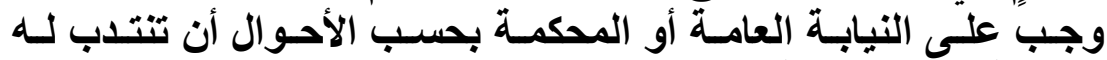

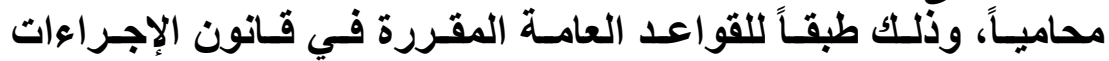

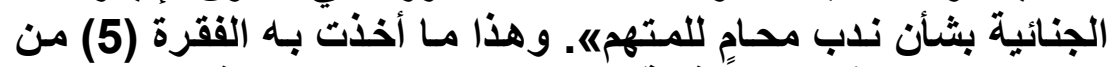

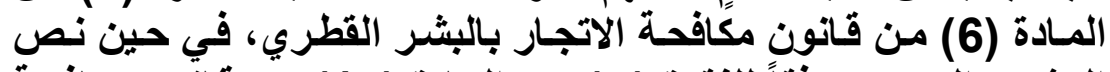

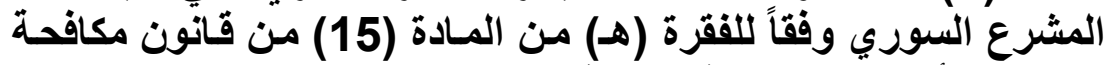

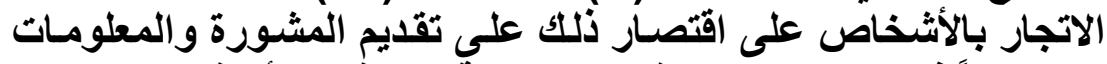

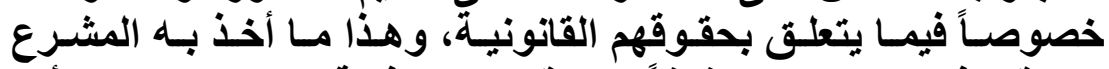

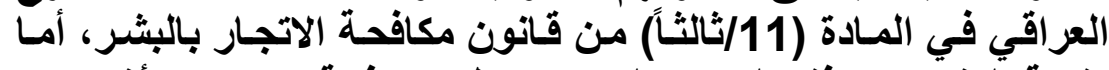

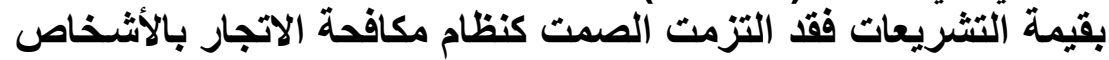

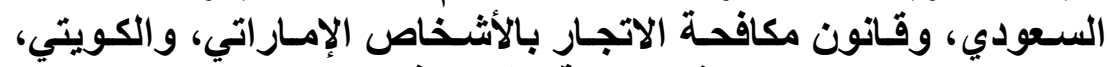

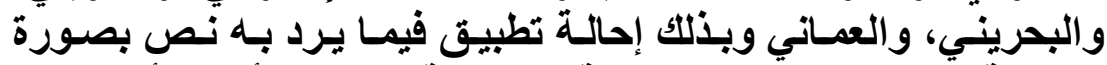

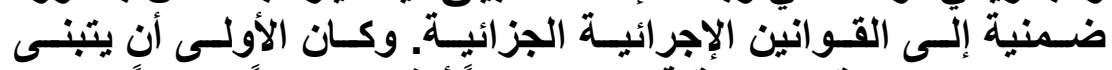

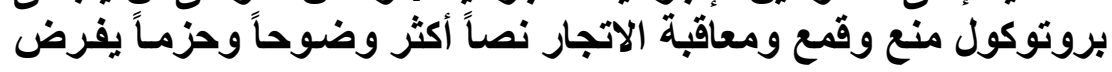

والجدير بالذكر أن بعض التشريعات أقرت بحق بالاستعانة بمحاٍٍ في مرحلة

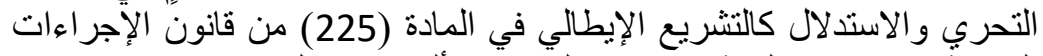

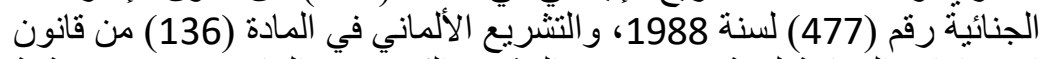

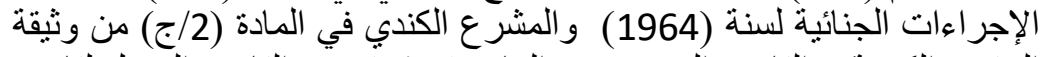
الحقوق الكندية، والقانون الفرنسي في المادة (4/63) من القانون المعدل لقانون الإجراءات الجنائية رقم (204) لسنة 2004. 
فيه على الدول الأطراف إقرار هذا الحق للضحية منذ مرحلة التحري

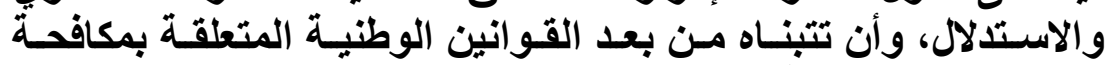

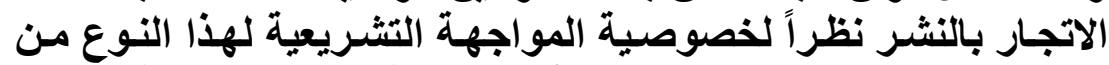

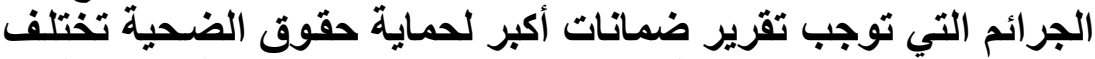
بطبيعتها عن القواعد العامة المقررة في القوانين الإجرائية الجزائية. خامساً: فرض تدابير خاصة لضحية الاتجار بالبشر. قـ تقتضي اعتبار ات معينة تتعلق بنوع وجنس وسن الضحية

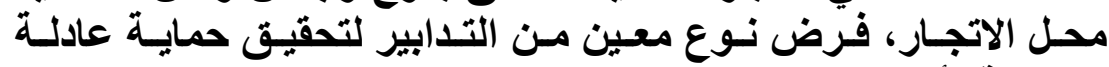
ومنصفة، أثناء مباشرة إجراءات فرع التحقيق الابتدائي.

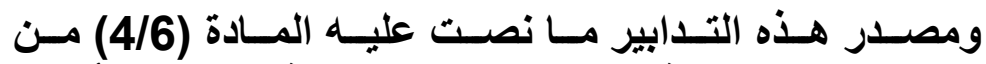

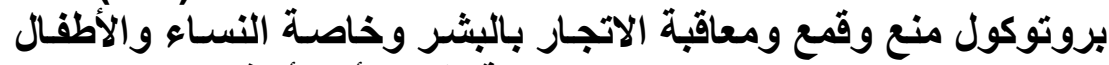

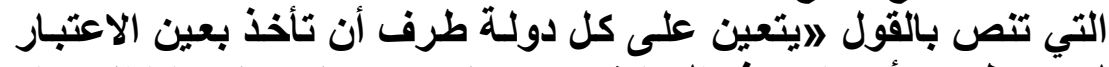

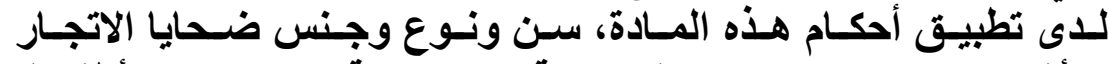

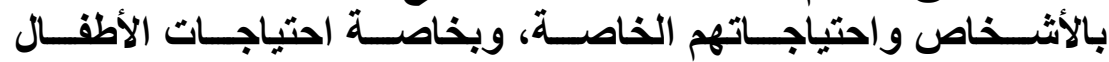

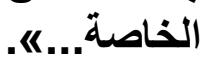

كما تستتد هذه التدابير على اتفاقية حقوق الطفل(1)، واتفاقية التهية

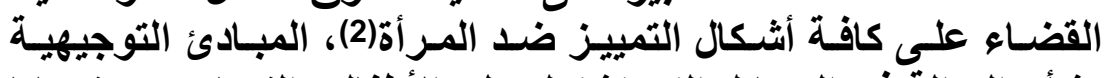

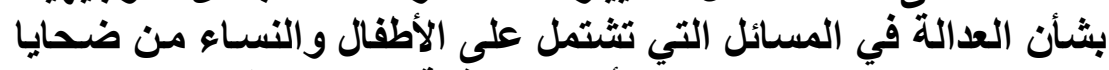

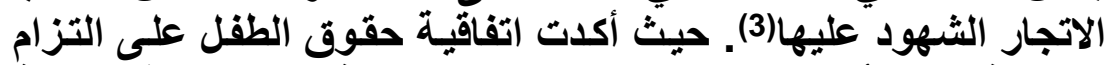

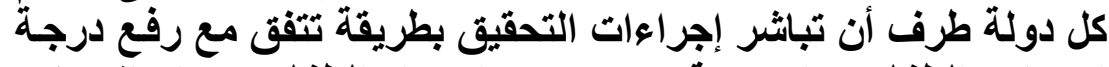

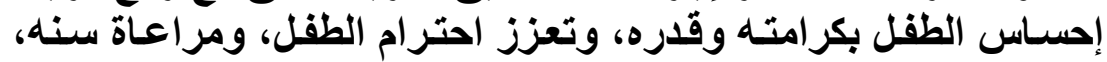

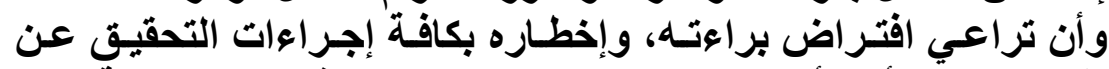

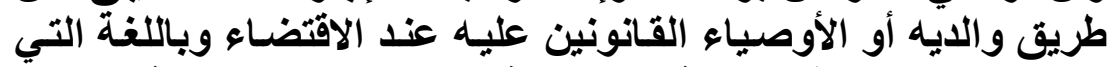

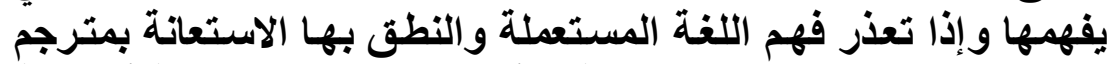

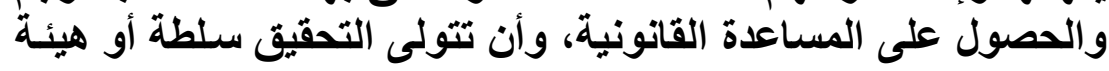

(1) اعتمدت وعرضت للتوقيع والتصديق والانضمام بموجب قرار الجمعية العامة فئ

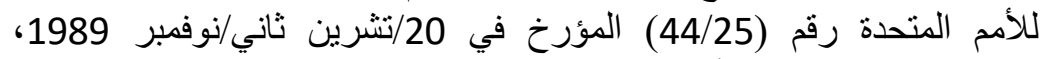
ودخلت حيز النفاذ في 2 أيلول /سبتمبر المرن 1990.

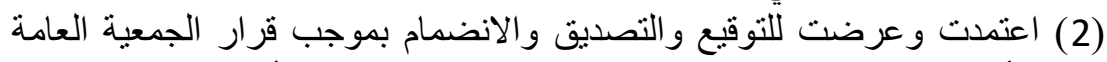

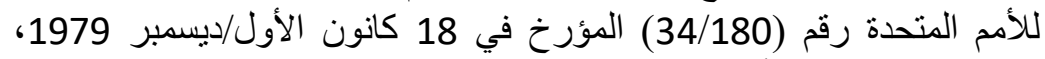

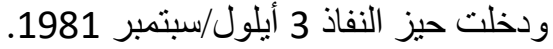

(3) مجموعة وثائق الأمم المتحدة، تقرير مفوضية الأمم المتحدة لحقوق الإنسان،

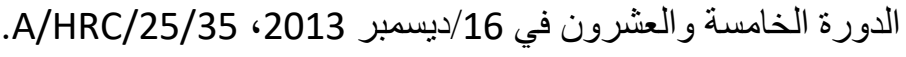




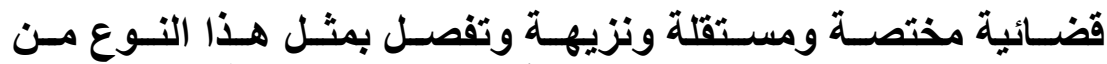

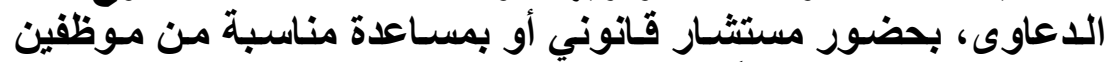

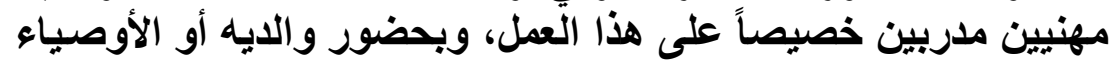

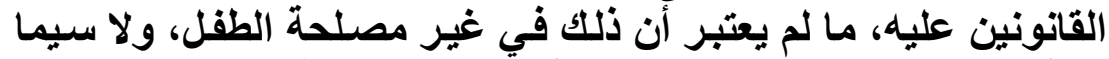

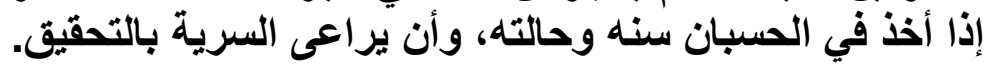

كما أكلد الفقرة الرابعة من المادة (40) على عدم جواز إكراه إذاه

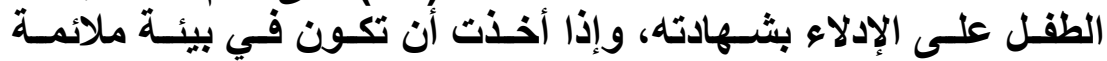

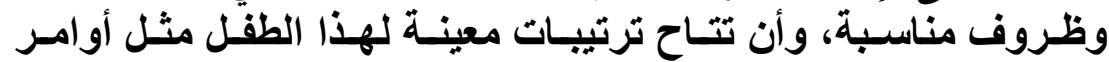

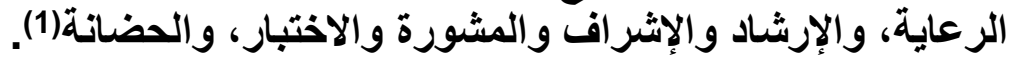

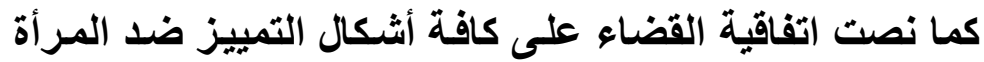

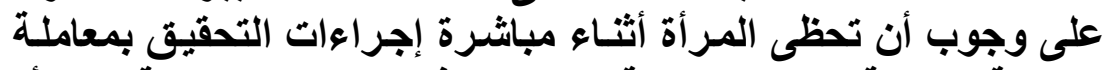

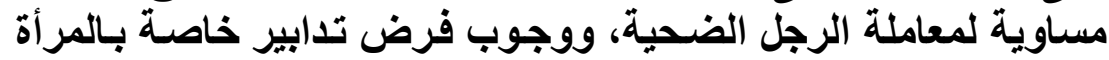

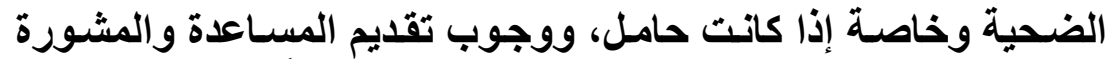

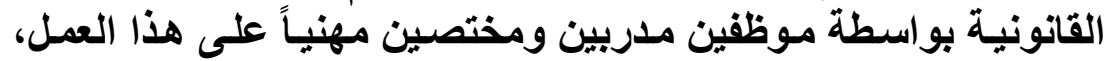

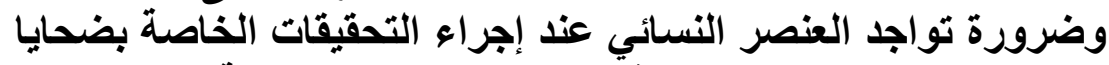

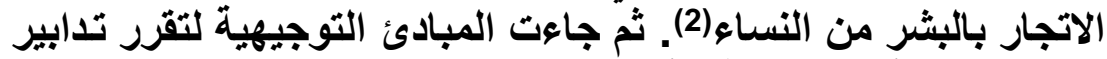

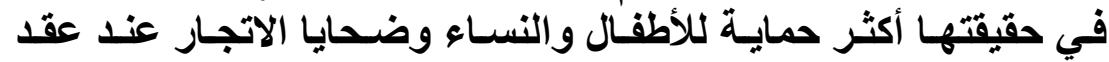

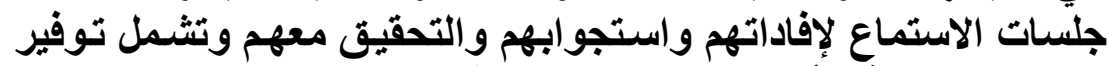

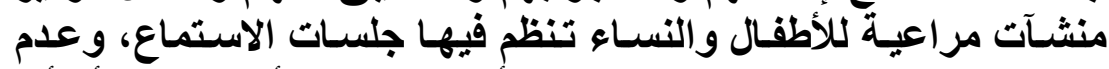

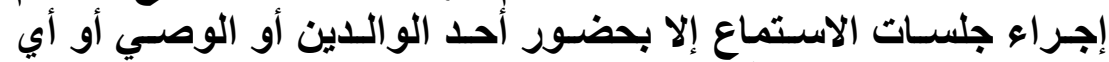

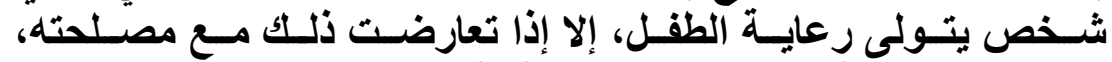

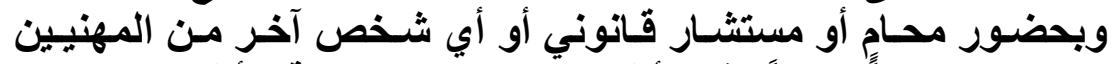

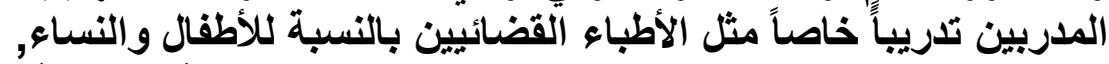

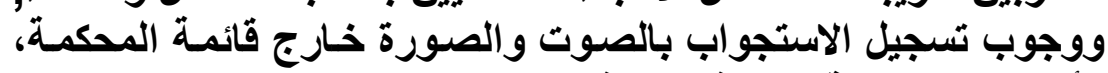

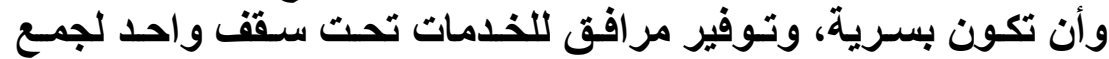

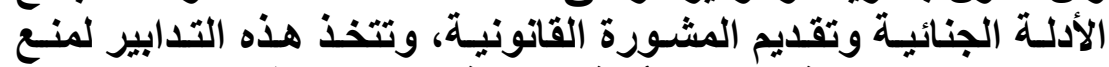

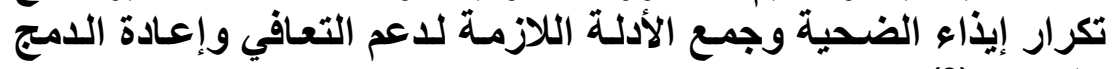

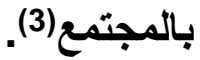

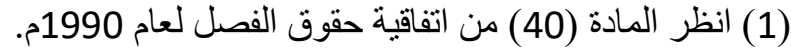
(2) انظر المادة (2/ج)، و المادة (11/د))، من اتفاقية القضاء على على كافة أثكال التمبيز

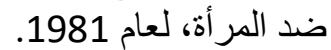

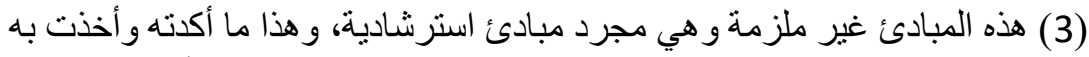

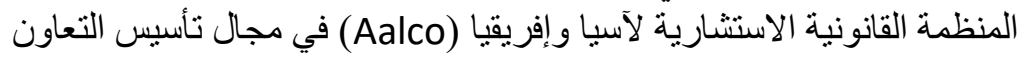
لمكافحة الاتجار بالنساء والأطفال (Aalco/48/PUTKAJAYA/2009/S8).
} 
وهذا مسا تبنـاه المشـرع المصري في المسادة (24) مـن قـانون

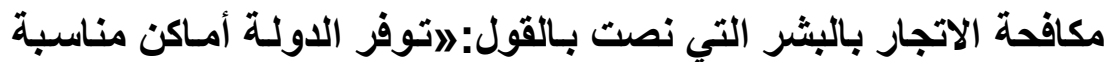

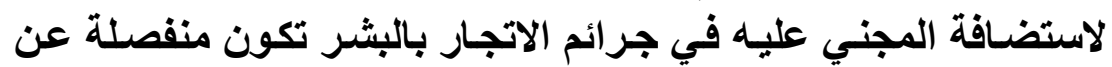

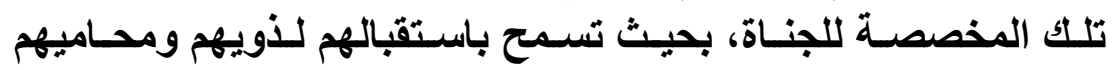

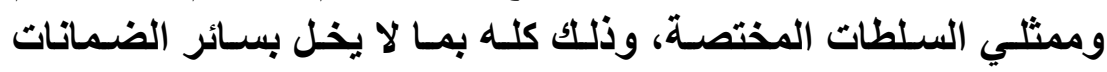

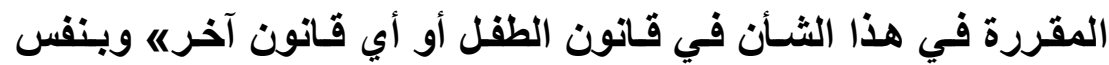

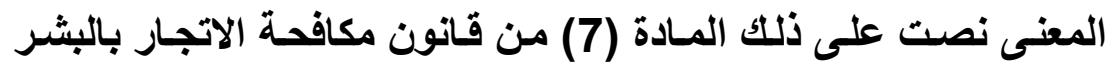

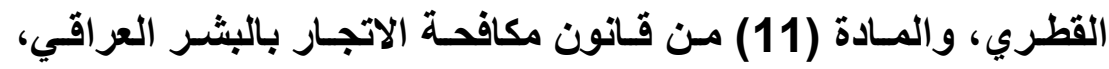

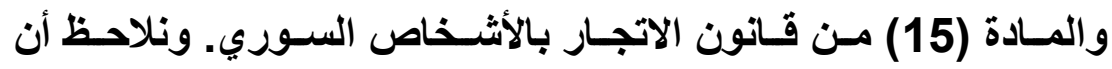

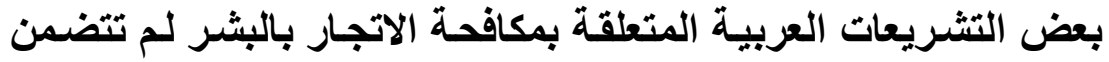

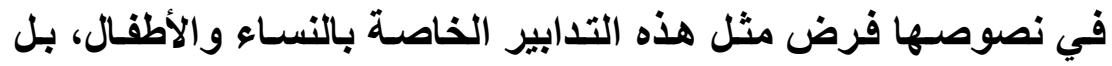

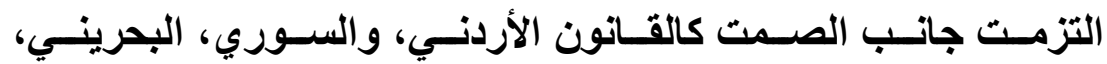

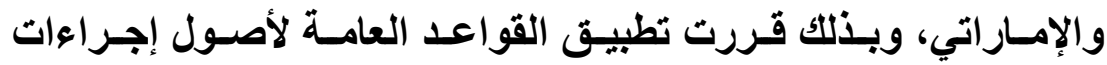

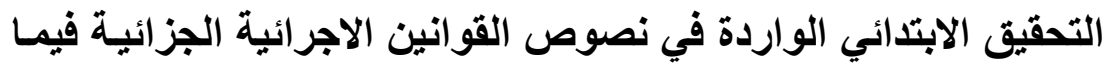

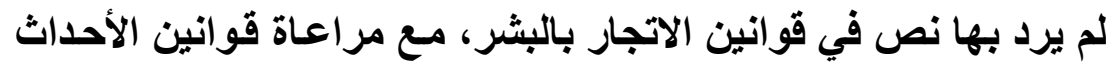

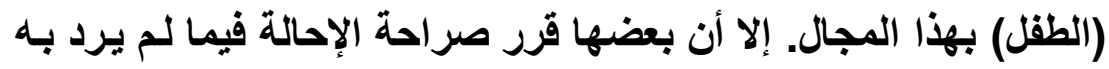

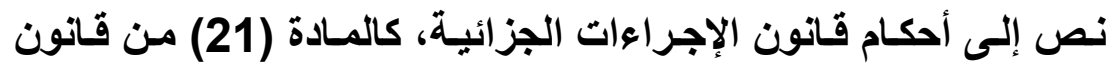
مكافحة الاتجار بالبشر العماني. المطلب الثالث

حقوق الضحية في مرحلة المحاكمة

$$
\text { أولاً: سرية إجراعات المحاكمة }
$$

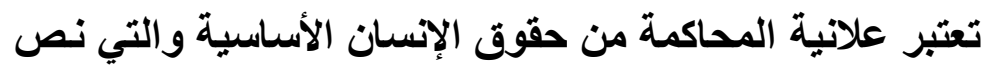

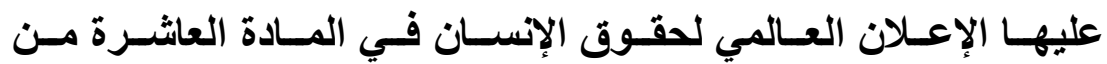

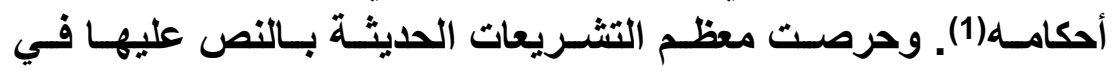


دساتيرها وقوانينها الإجرائية(1) لأن من شأن ذلك أن يدعم الثقة بأحكام

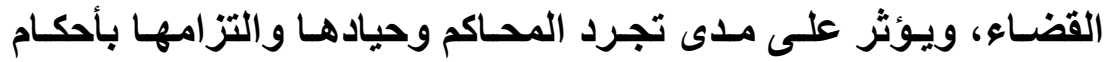

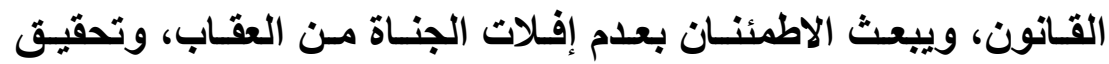

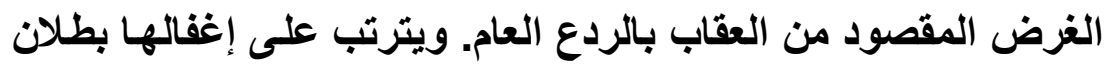
الإجراعات المتخذة فيها(2)، إلا أن تلاوة الحكم يجب أن أن تكون علنية علئ.

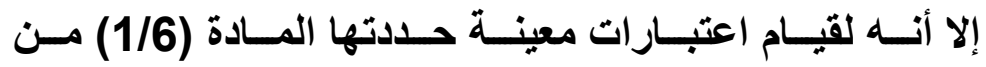

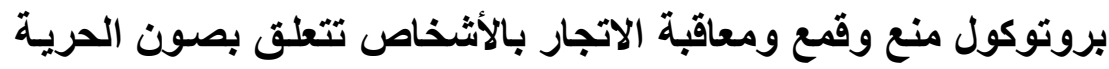

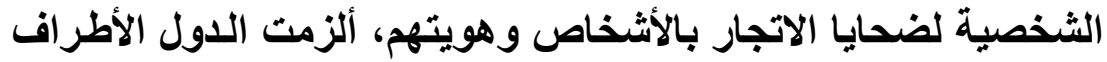

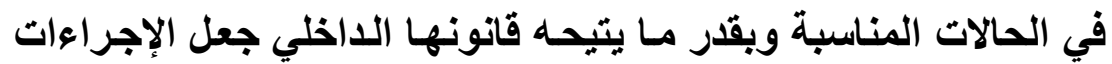

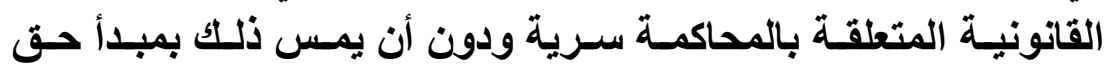

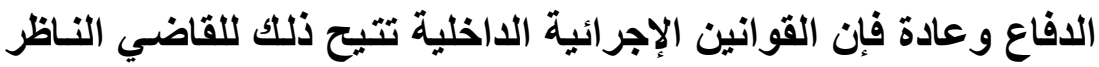

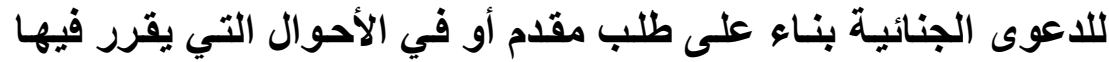
القانون ذلك مراعاة للنظام العام والآداب العامة.

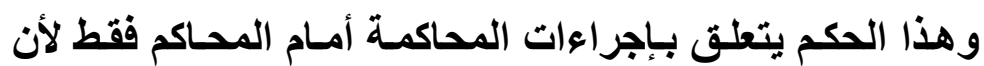

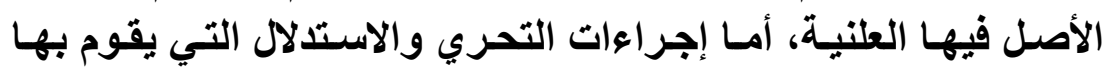

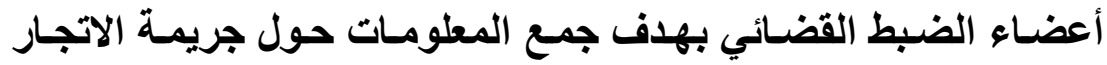

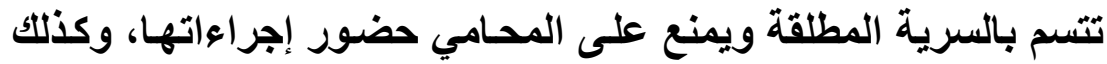

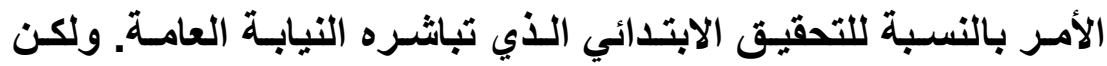

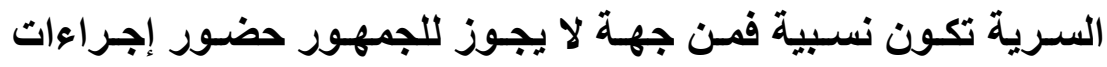

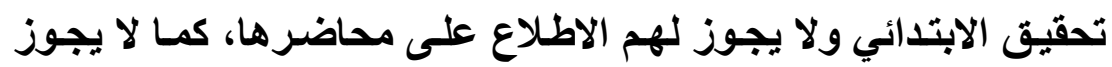

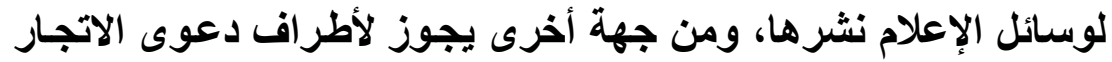
ووكلائهم حضور هذه التحقيقات والاطلاع على محاضر هاء

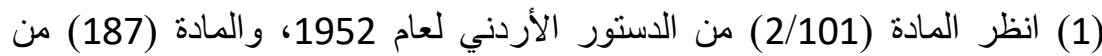

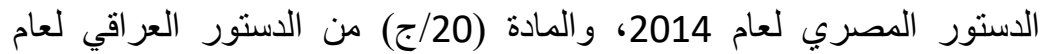

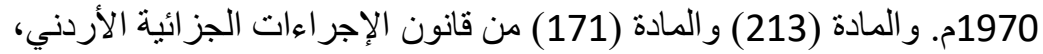

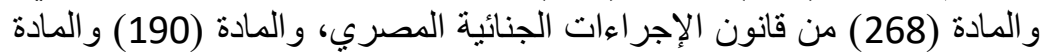

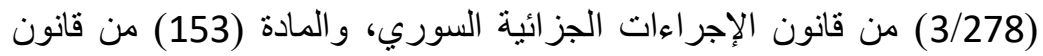

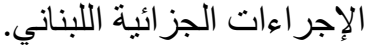
(2) د. جعفر محمد خضير، الحق في محاكمة عادلة، رسالة دكتور اةة، جامعة بغداد، 
وبينت الفقرتـان (2/1/ب) من اتفاقيـة الأمم المتحدة لمكافحسة

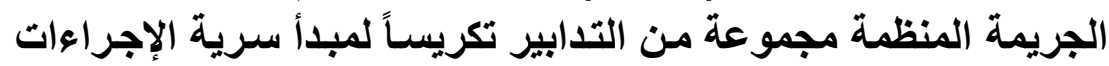

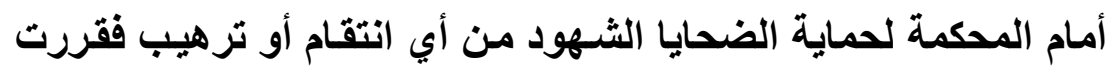

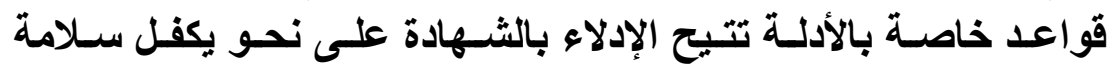

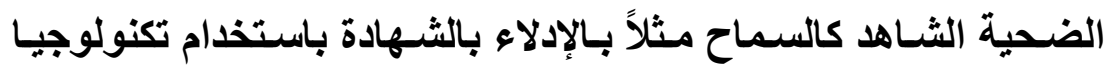

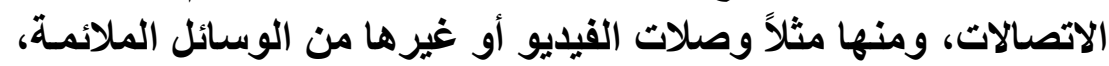

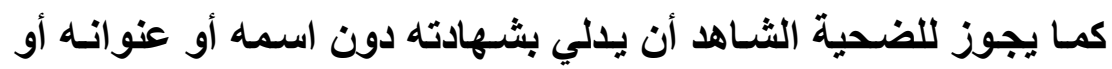
أي معلومات تتعلق بهويته للجمهور.

وقد جاءت المبادئ التوجيهية بشأن العدالة في مسائل ضحايا

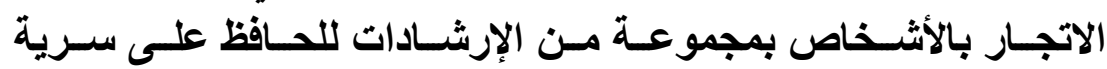

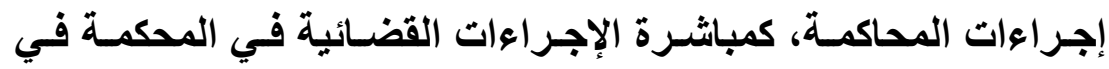

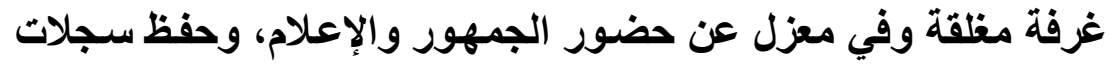

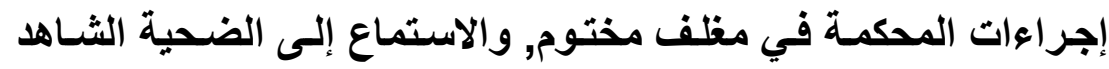

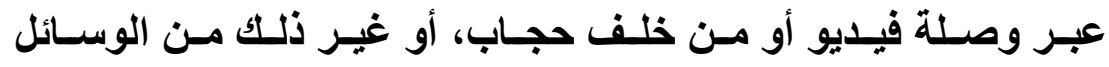

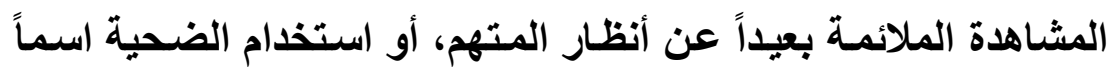

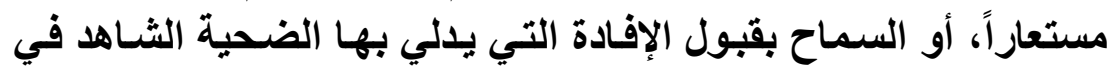

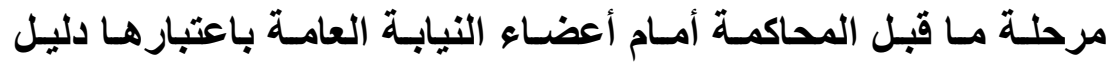

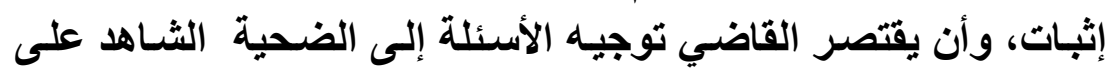

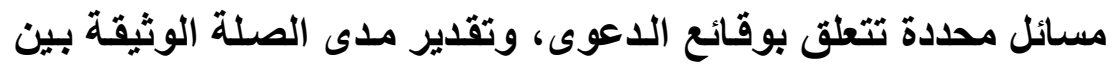

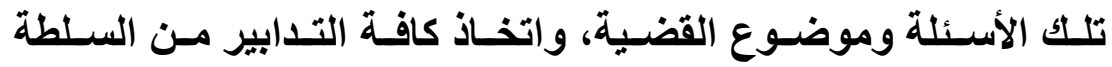

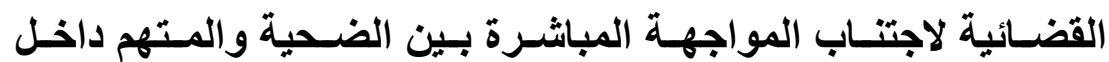

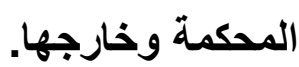

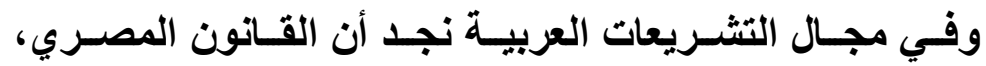

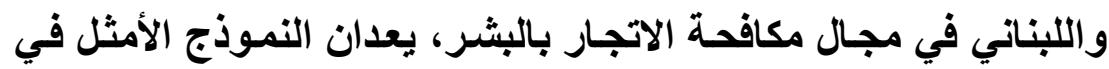

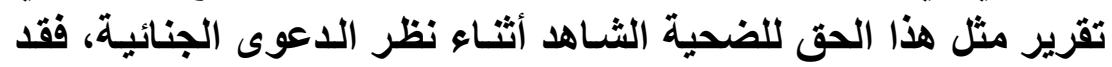

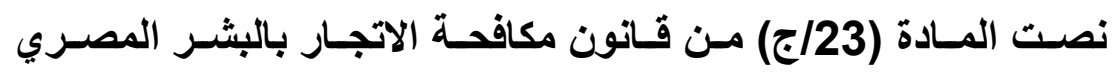

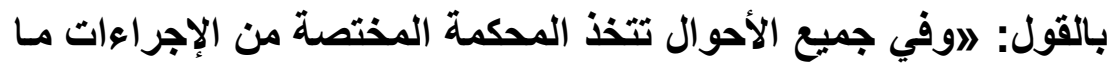

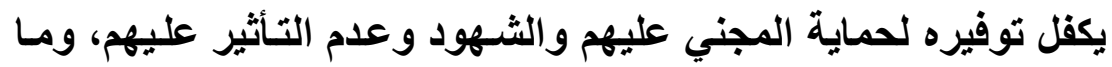

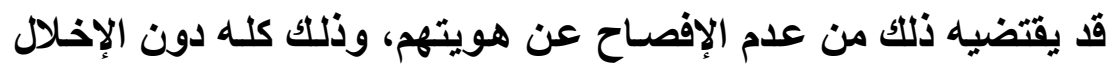

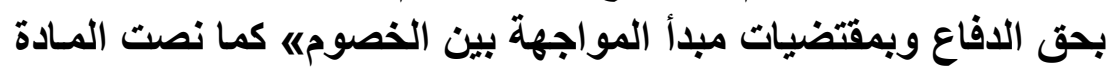




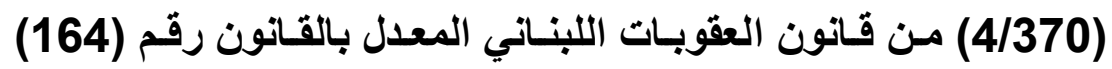

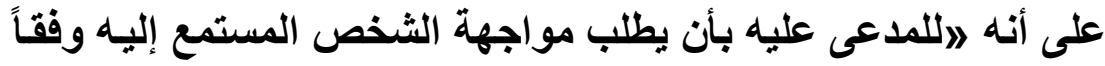

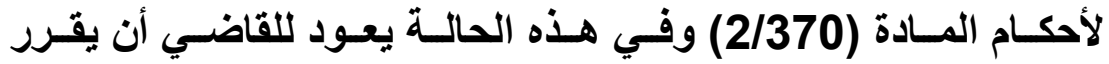

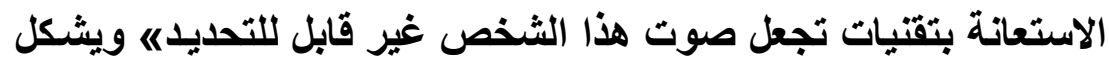

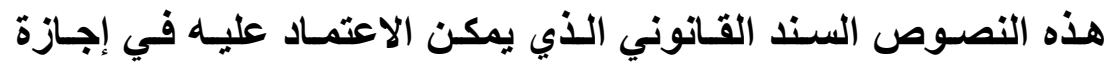

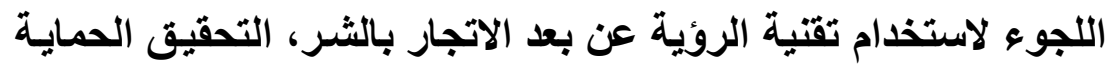

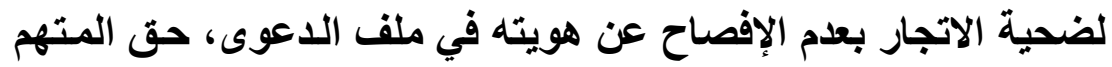

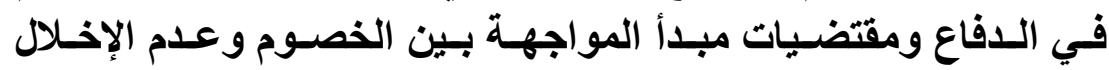

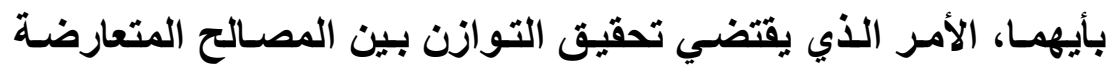

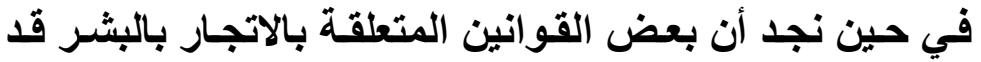

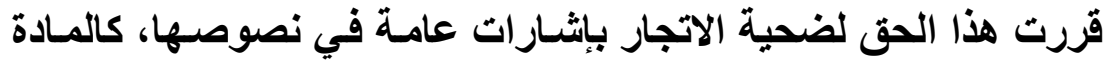

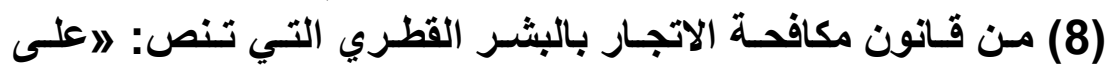

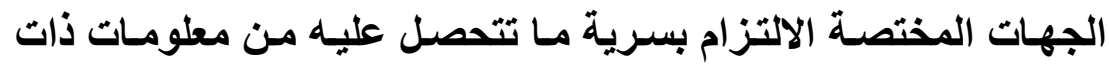

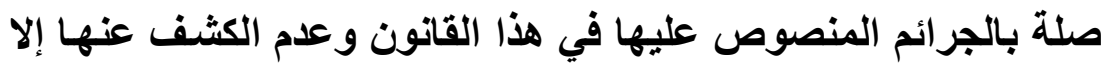

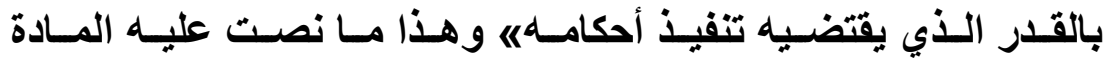

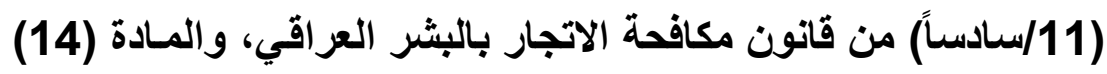

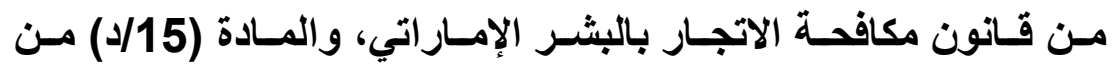

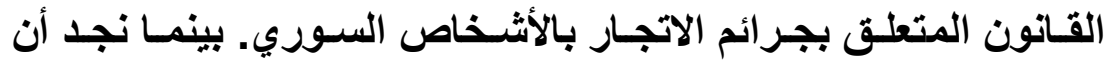

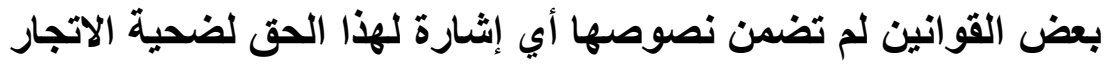

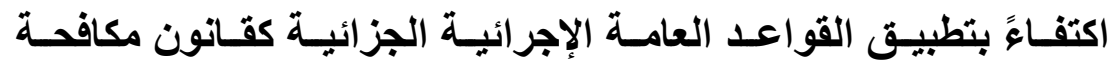

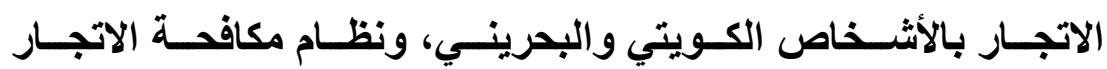

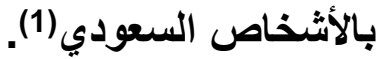

(1) نظمت المادة (52-706) من قانون الإجراءات الفرنسي استخدام الوسائل الإئل

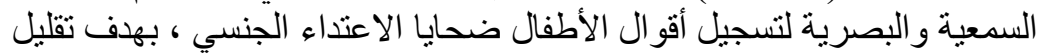

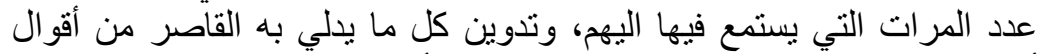

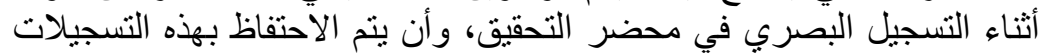

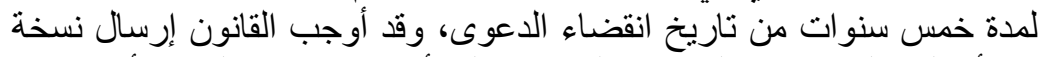

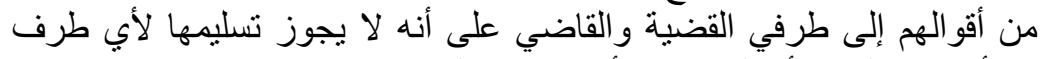
من أطر اف النزاع أو الدفاع إلا بأمر قاضي التحقيق الته 
Artticle 706-52 Au cours de l'enquête et de l'information, l'audition d'un mineur victime de l'une des infractions mentionnées á l'article 706-47 fait l'objet d'un enregistrement audiovisuel. L'enregistrement prévu á l'alinéa précédent peut être exclusivement sonore sur décision du procureur de la République ou du juge d'instruction, si l'intérêt du mineur le justifie . Le procureur de la République ou du juge d'instruction ou l'officier de police judiciaire chargé de l'enquête ou agissant sur commission rogatorie peut requérir toute personne qualifiée pour procéder á cet enregistrement . Les dispositions de l'article 60 sont applicables á cette personne, qui est tenue au secret professionnel dans les conditions de l'article 11. II est par aillieurs établi une copie de l'enregistrement aux fins d'en faciliter la consulation ultérieure au cours de la procédure. Cette copie est versée au dossier. L'enregistrement original est placé sous scellés fermés . Sur décision du juge d'instruction, l'enregistrement peut être visionné ou écouté au cours de la procédure. La copie de ce dernier peut être toutefois visionné ou écoutée par les parties, les avocats ou les experts, en présence du juge d'instruction ou d'un greffier, Les huit derniers alinéas de l'article 114 du code de procédure pénale ne sont pas applicables á l'enregistrment . La copie de ce dernier peut toutefois être visionnée par les avocats des parties du palais de justice dans des conditions qui garantissent la confidentialité de cette consultation, lorsque l,enregistrement ne peut être effectué en raison d'une impossibilité technique, il en est fait mention dans le procés - verbal d'audition qui précise la nature de cette impossibilité . Si l'audition intervient au cours de l'enquête ou sur commission rogatorie, le procureur de la Répulique ou le juge d'instruction en est immédiatement avisé . Le fait , pour toute peronne, de diffuser un enregistrement ou une copie réalisée en application du présent article est puni d'un un d'emprisonnement et de 15000 euros d'amende. A l'expiration d'un délai de cinq ans á compter de la date de 

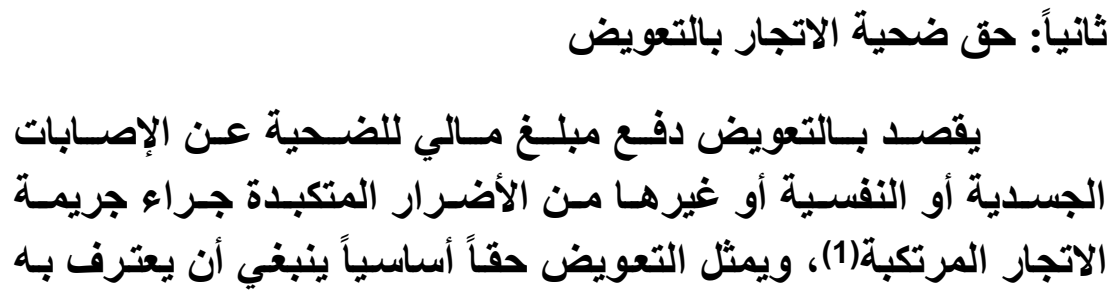

I'extinction de l'action publique, l'enregistrement et sa copie sont détruits dans le délai d'un mois".

Article 706-71 "Lorsque les nécessités de l'enquête ou de l'instruction le justifient, l'audition ou l'interrogatorie d'une personne ainsi que la confrontation entre plusieurs personnes peuvent être effectués en plusieurs points du territoire de la République se trouvant reliés par des moyens de télécommunications grantissant la confidentialite de la transmission. Dans les mêmes conditions, la présentation aux fins de prolongation de la garde á vue ou de la retenue judiciaire peut être réalisée par l'utilisation de moyens de télécommunications audiovisuelle, II est alors dressé, dans chacun des lieux, un procés verbal des opérations qui y ont été effectuées. Ces opérations peuvent faire l'object d'un enregistrement audiovisuel ou sonore, les dispositions des troisiéme á huitiéme alinéas de l'article 706-52 sont alors applicable .... Elles sont de même applicables devant la commission d'indemnisation des victimes d'infraction, devant le premier président de la cour d'appel statuant sur les demandes de réparation d'une détention provisoire, devant la Commission nationale de réparation d,une detentions provisoire, devant la commission devant la commission nationale de réparation des détentions devant la cfommission et la cour de révision et devant la commission de réexamen des condammations...

وقد أقرت (31) و لاية أمريكية استخدام الدو ائر التلفزيونية الدغلقة يدلي من خلالها

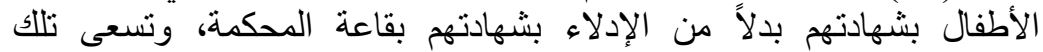
التشريعات إلى إعادة الموازنة بين الحاجة إلى شهادة الضحية مع حق المتهم في مو اجهة الشهود.

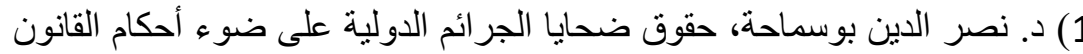

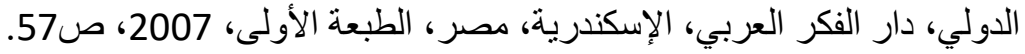


للضحية في إطار عملية جبر الأضرار، حيث يوفر لهم مزيداً من الثقة

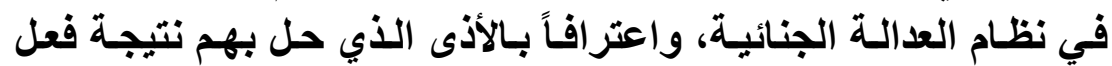

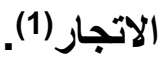

ويتحدد التعويض من المحكمة النـاظرة لجريمـة الاتجار بحسب

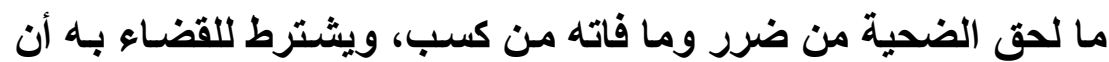

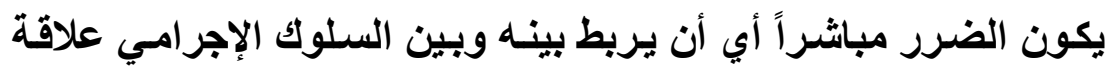
سبيبة، ويكون نتيجة مباشرة لفعل الاتجار الإجرامي(2).

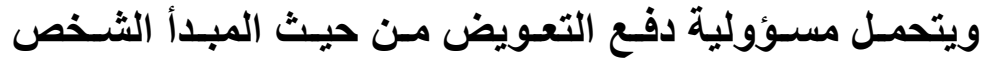

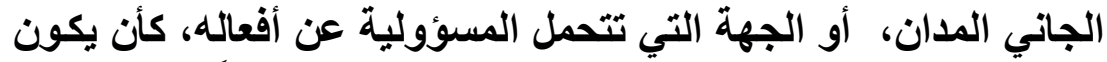

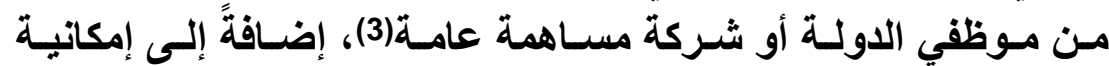

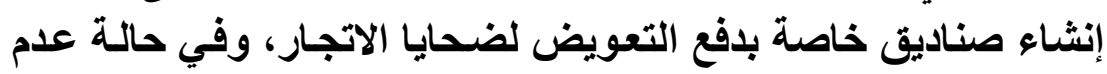

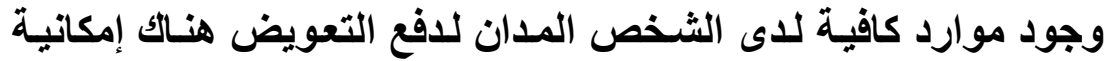

لتحميله للاولة (4).

وقد تبنـت المسادة (6/6) مـن بروتوكـول منـع وقمـع ومعاقبـة

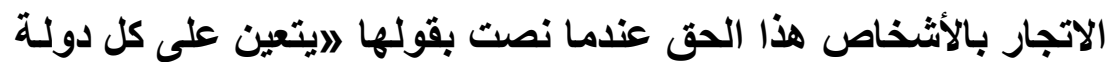

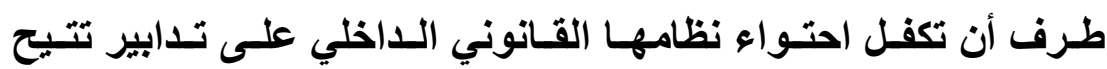
لضحايا الاتجار بالأثخاص إمكانية الحصول على تعويض عن الأضران الترار

(1) د. نبيل عبد الرحمن ناصر الدين، ضمانات حقوق الإنسان وحمايتها وفقاً للقانون الدولي،

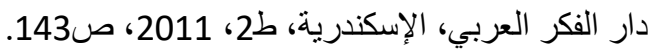

(2) Anne D'HAUTVILLE: les droits des victmes, Rev.Sc.crim Janv, mars 2001, p. 85.

(3) William TALLACK; reparation to the injured and the rights of the victmes of crime to compensation, London, 2008. p.136.

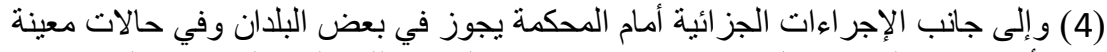

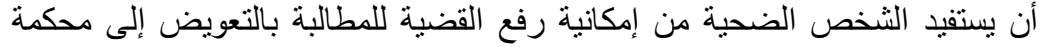

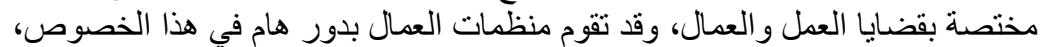

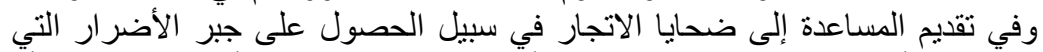

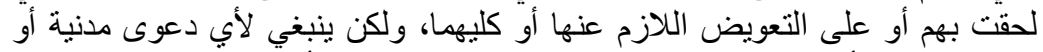

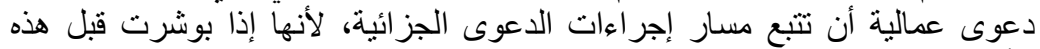
الأخيرة فإنها لابد من إرجائها إلى حين الفصل في الدعوى الجئ الجنائية و هذا ما يعرف

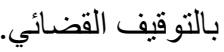


التي لحقت بهمه وكنلك أقرته المادة (2/25) من اتفاقية الأمم المتحدة لمكافحة الجريمة المنظمة عبر الوطنية.

وبهذا يشير البروتوكول والاتفاقيـة إلى تمكين ضحية الاتجـار

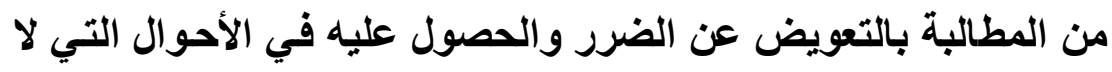

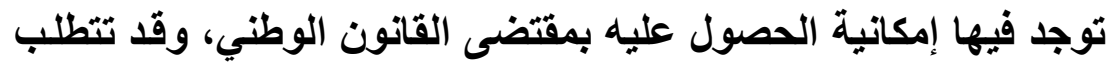

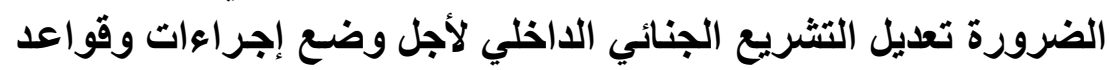

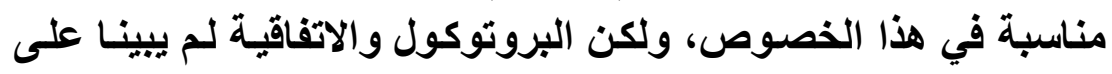

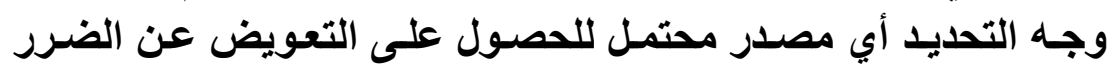
الذي أصاب الضحية من جريمة الاتجار.

لهذا جاءت الفقرة (12) من إعلان الأمم المتحدة لتوفير العدالة

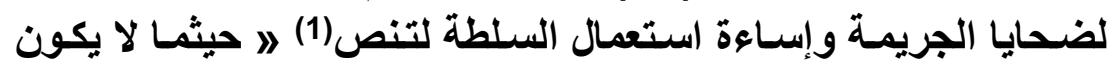

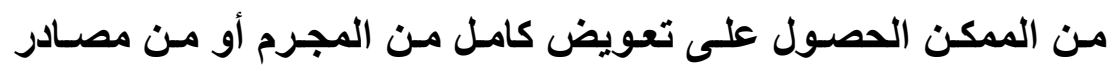

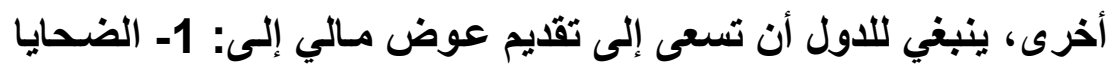

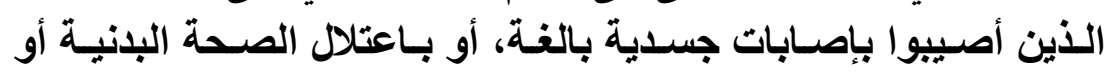

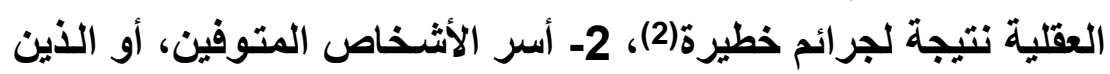

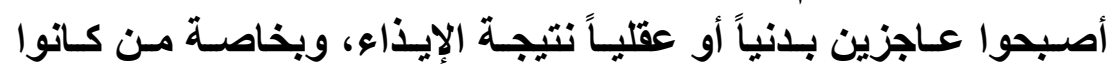

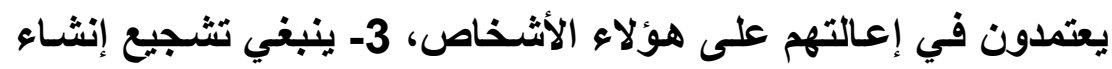

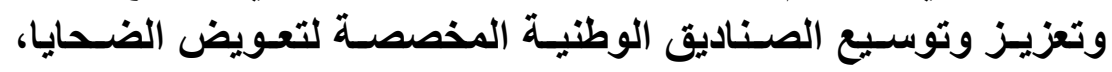

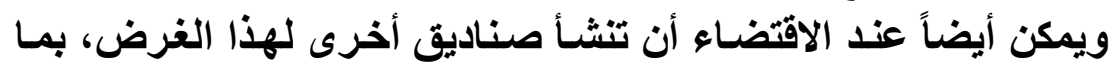

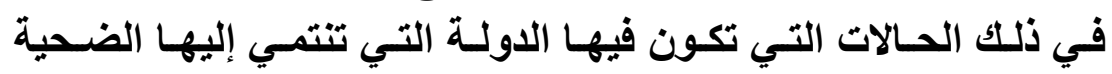

(1) الفقرة (12) من إعلان الأمم المتحدة بشأن المبادئ الأساسية لتوفير العدالة

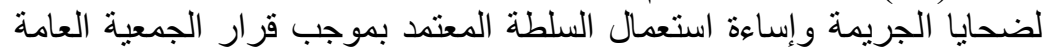

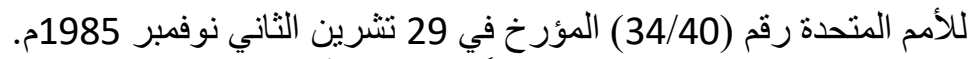

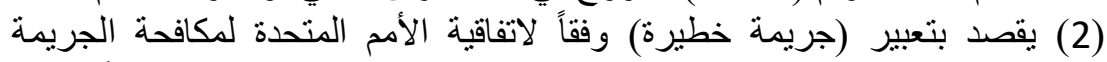

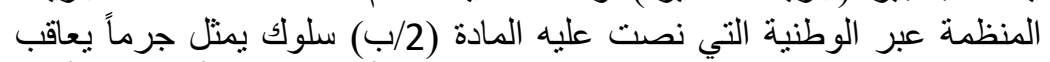

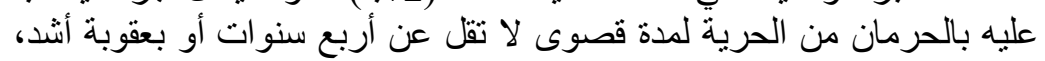

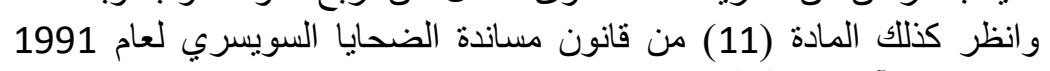
بصيغته في آخر نعديل له في عام 2005م. 
عاجزة عن تعويضها عما أصابها من ضرره(1)، والمتأمل بالتشريعات العربية في هذا المجال يلاحظ بداية:

(أ) أن الكثير منهـا لـم ينص على هذه الضـمانة في أحكامها،

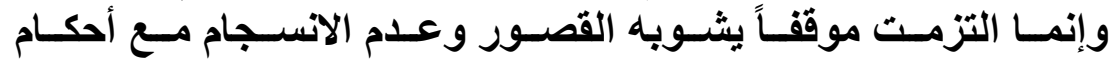

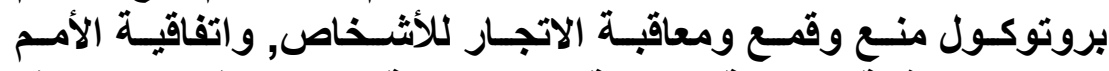

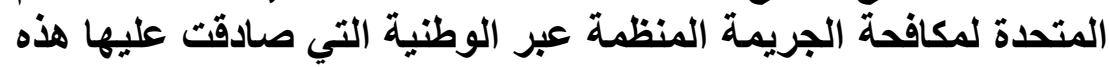

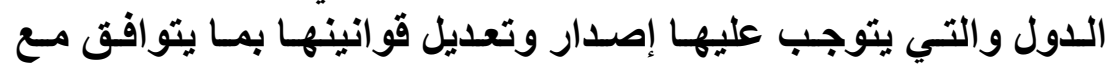

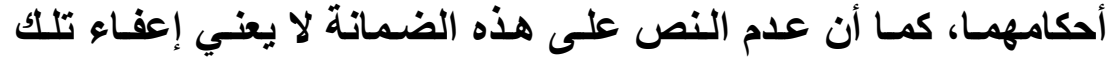

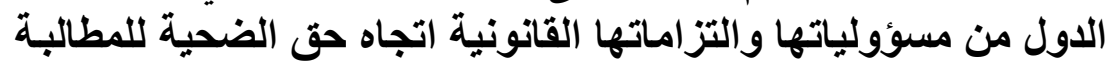

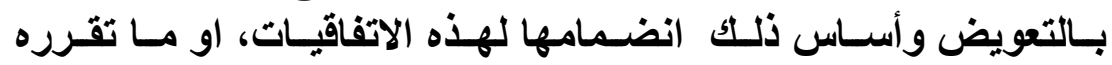

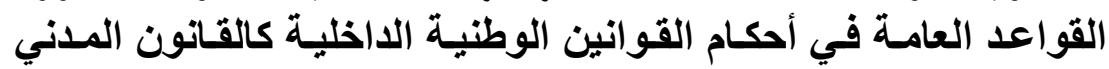

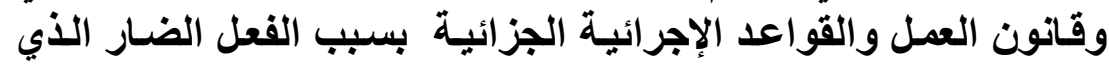

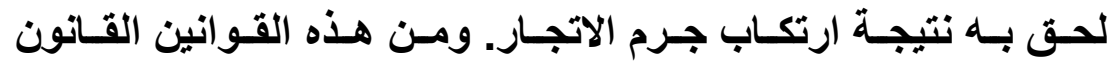

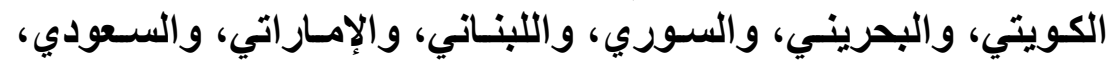

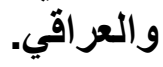

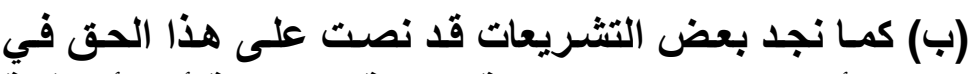

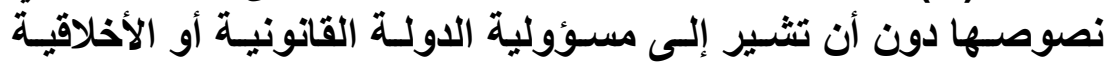

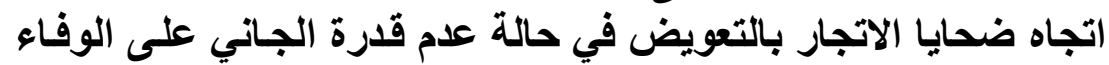

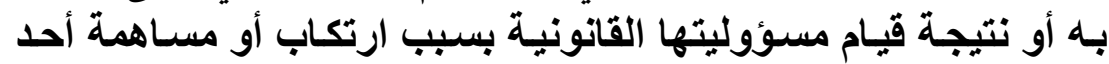

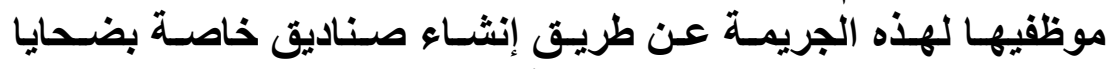

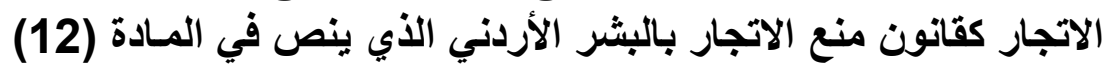

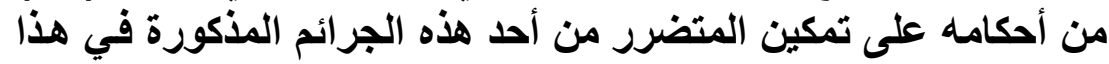

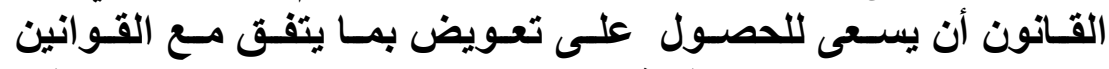

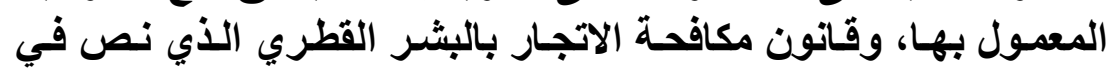

من الأفضل إنشاء صندوق واحد لأن إدارة صندوق أسهل من حيث الإدارة

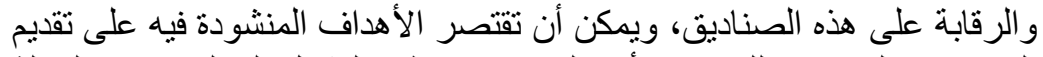

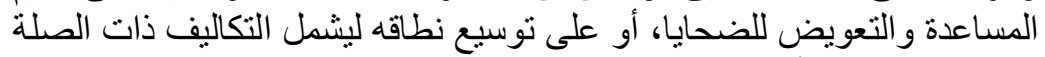

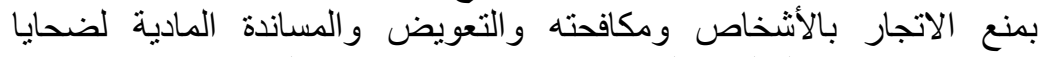

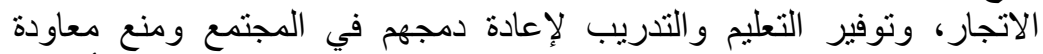

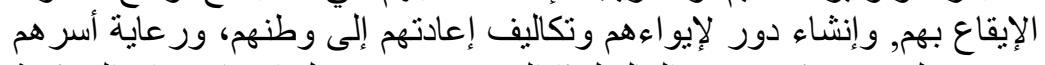

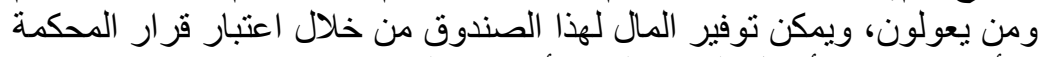

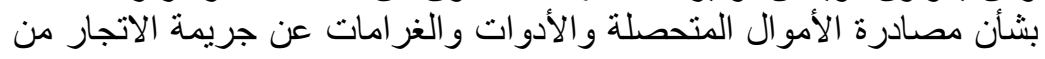
موارده مع قبول التبر عات و الهبات. 


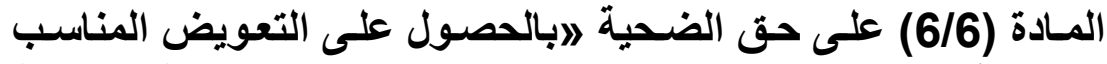

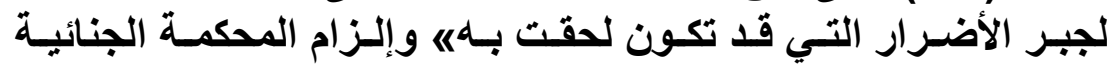

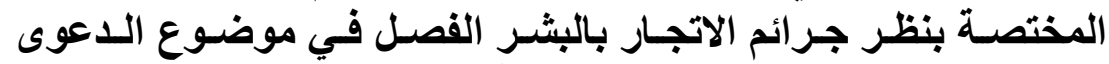

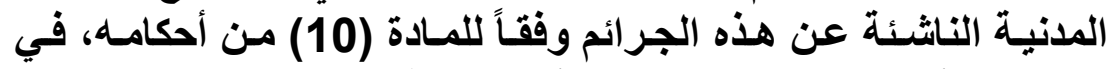

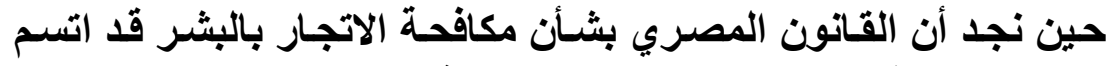

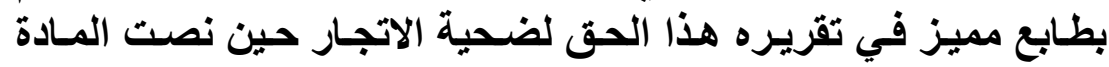

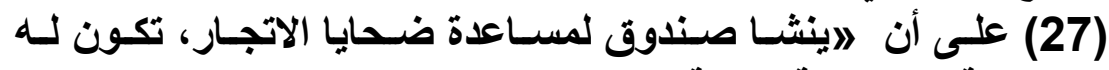

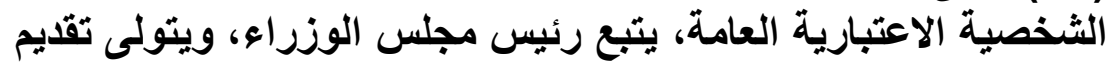

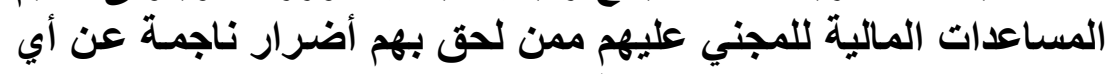

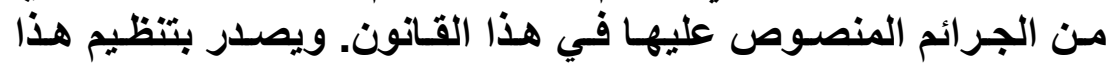

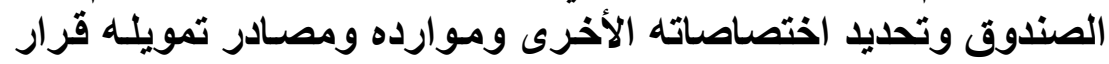

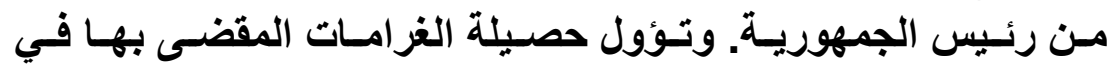

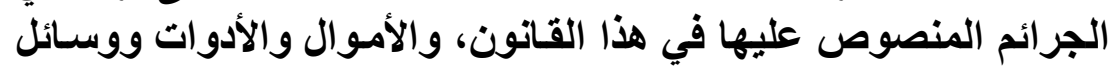

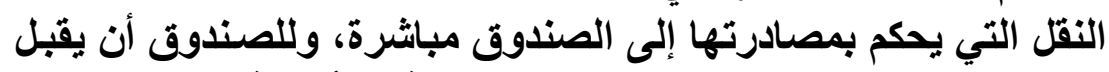
التبرعات والمنح والهبات من الجهات الوطنية والأجنبيةة) (1).

(1) قرر هذا الحق لضحية الاتجار المشرع الفرنسي وفقا للمادة 316 /1 من قانون

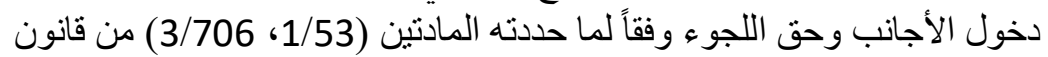

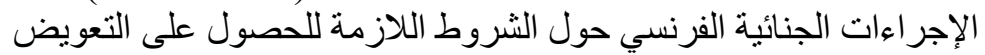

Article 706-3 En savoir plus sur cet article .. Modifié par Loi $n^{\circ}$ 2004-204 du 9 mars 2004-art, 169 JORF 10 mars 2004 en vigueur le ler janvier 2005. Toute personne ayant subi un préjudice résultant de faits volontaires ou non qui présentent le caractére matériel d'une infration peut obtenir la réparation intégrale des dommages qui résultent des atteintes á la personne, lorsque sont réparation intégrale des dommages qui résultent des atteintes á la personne, lorsque sont réunies les conditions suivantes: 1Ces atteintes n'entrent pas dans le champ d'application de l'article 53 de la loi de financement de la sécurité social pour 2001 ( ${ }^{\circ} 2000-1257$ du 23 décenbre 2000) ni de l'article L. 1261 du code des assurances ni du chapitre ler de la loi $n^{\circ}$ 85-677 du 5 juillet 1985 tendant á l'amélioration de la situation des victimes d'accidents de la circulation et á l'accélération des procédures d'indemnisation et n'ont pas pour origine un acte de chasse ou de destruction des 
ثالثاً: ضمانة المساواة في العقاب بين الثروع والجريمة التامة.

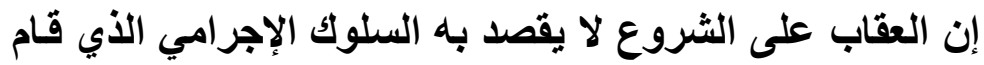

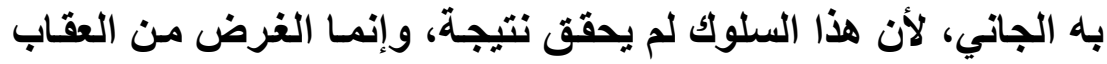

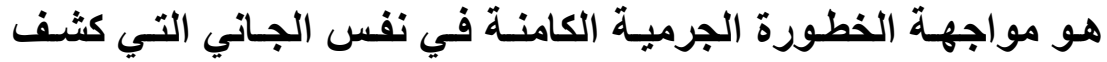

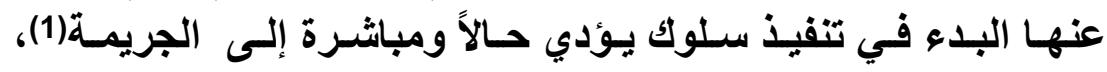

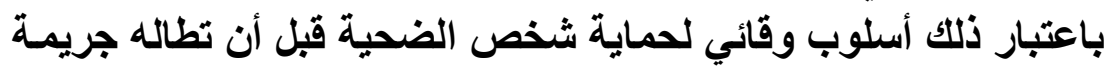

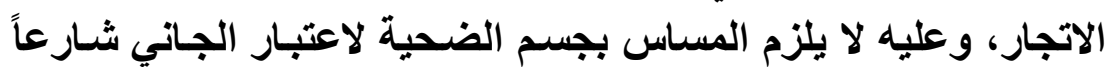

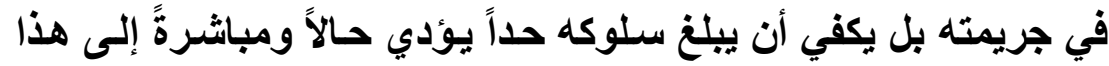

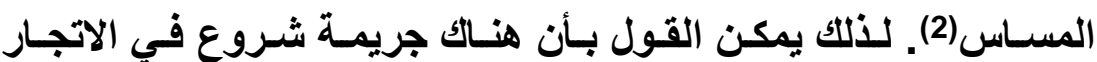

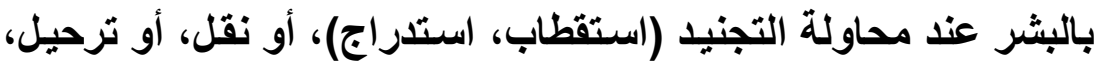

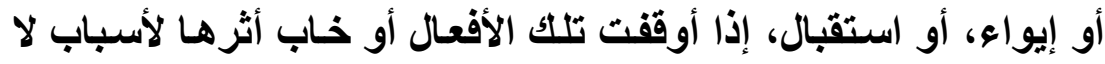

animaux nuisibles , 2- Ces faits: soi ont entraîné la mort , une incpacité permanente ou une incpacité totale de travail personnal égale ou supérieure â un mois , - soit son prévus et réprimés par les articles 222- 22 á 222- 30, 225-4- 1 á 225-4-5- et 227-25 et 227- 27 du code pénal , 3- La personne lésée est de nationalité francaise, Dans le cas contrire, les faits ont été commis sur le territoire national et la personne lésée est, soit ressortissante d'un Etat membre de la Communauté économique européenne, soit sous réserve des traités et accords internationaux, en séjour régulier au jour des faits ou de la demande. La réparation peut être refusée ou son montant réduit á raison de la faute de la victime.

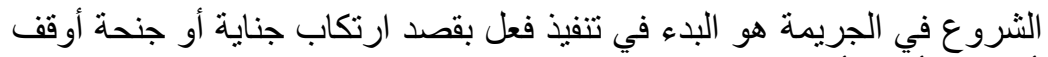

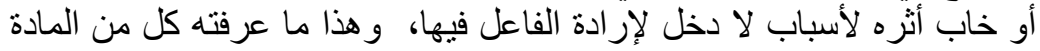

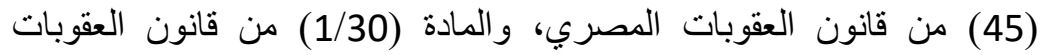

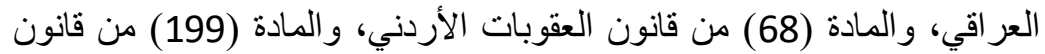

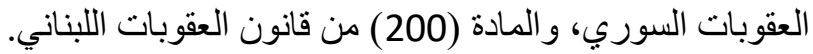

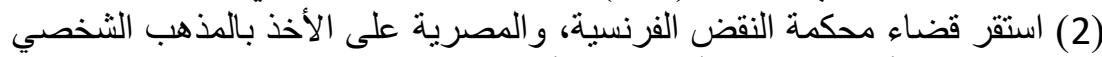

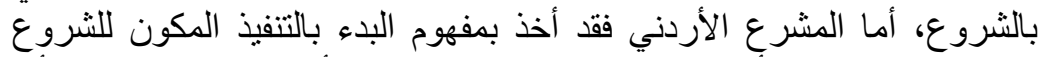

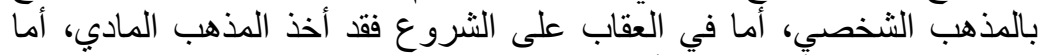

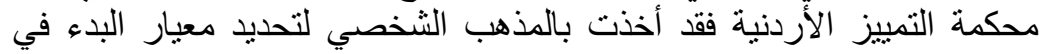

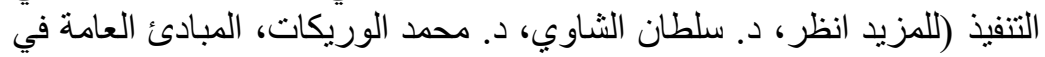

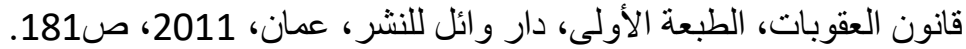




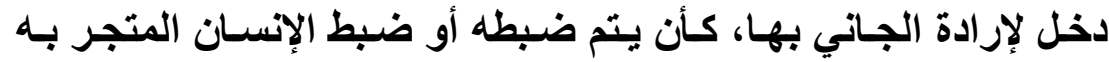

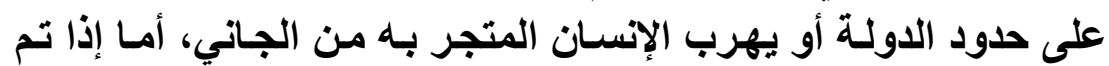

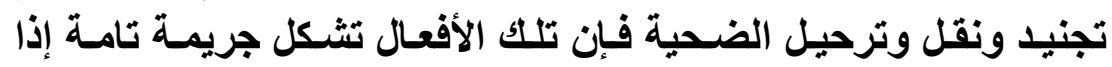

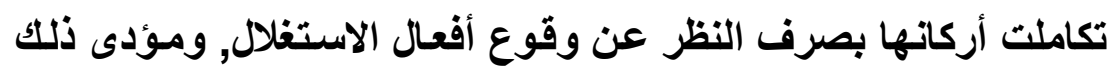

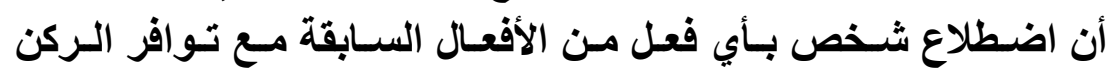

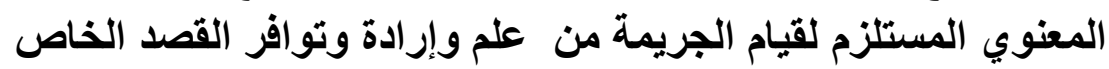

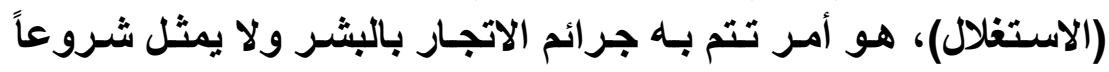

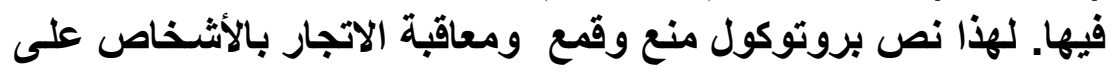

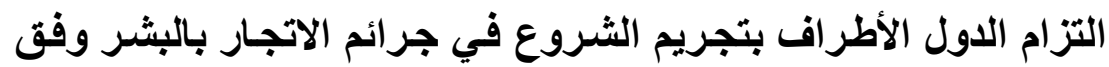

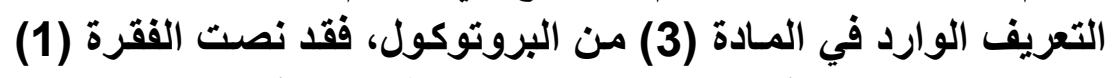

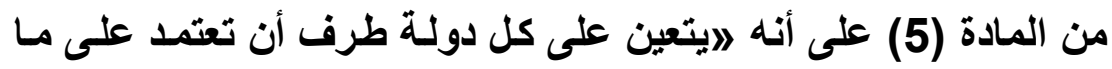

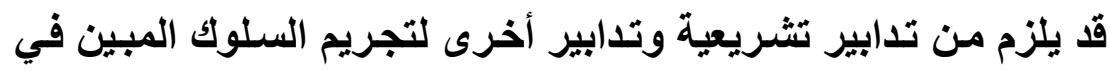

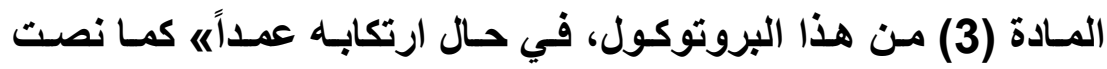

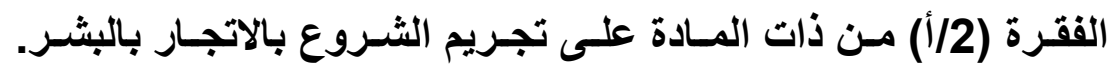

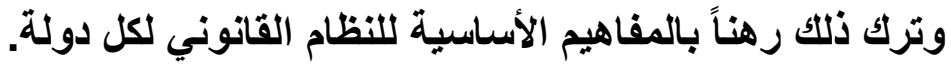

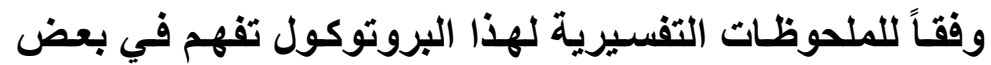

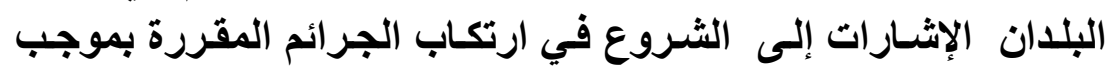

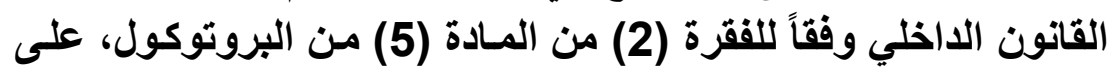

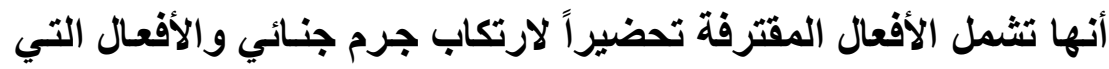

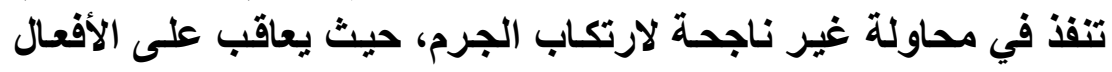

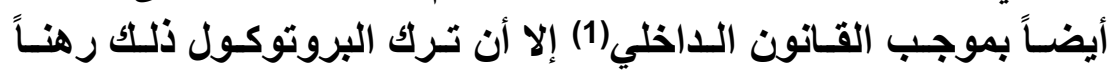

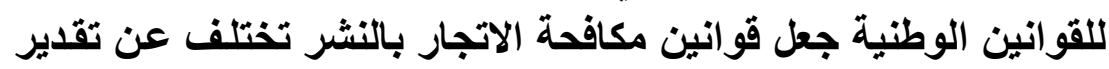

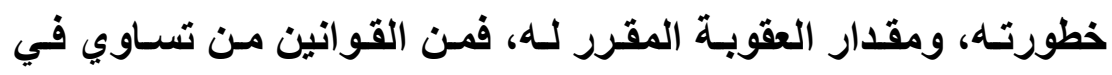

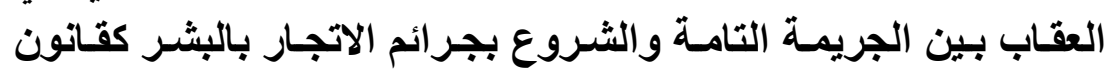

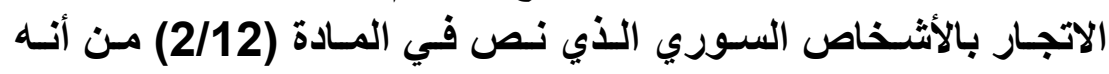

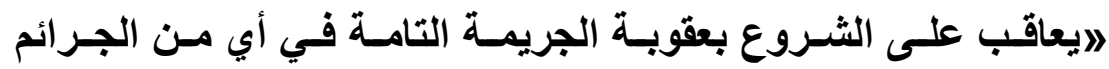

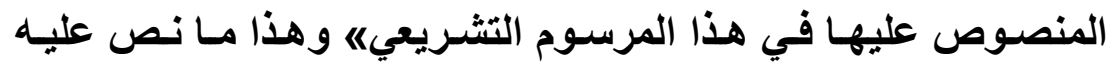

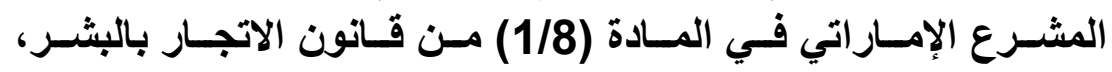

الفقرة (70) من الملحوظات التفسيرية، وثائق الأمم المتحدة

(A/55/383/Add.1) 


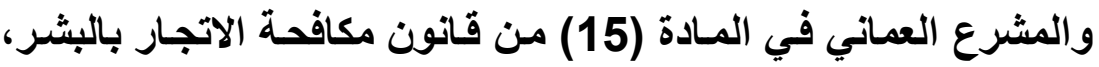

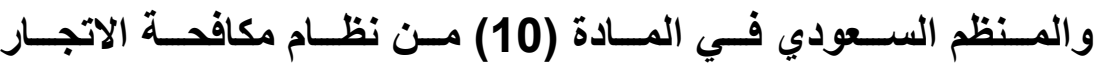

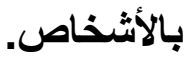

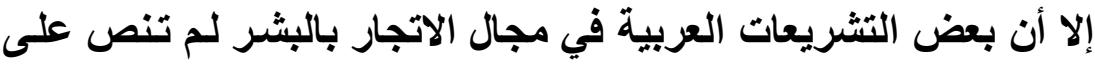

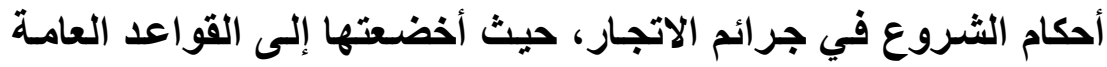

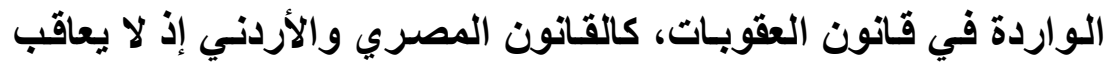
على الثروع وفق القواعد العامة إلا في الجنايات.

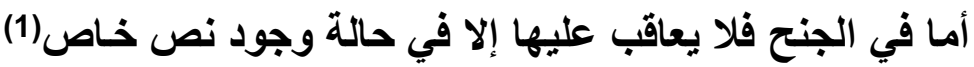

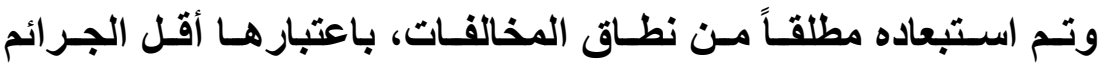

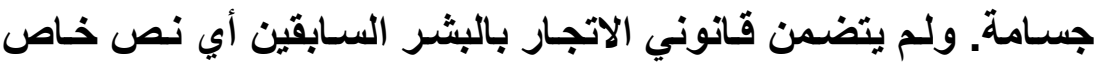

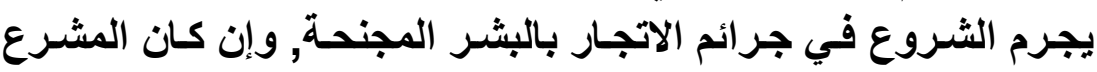

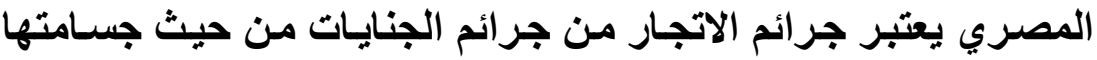

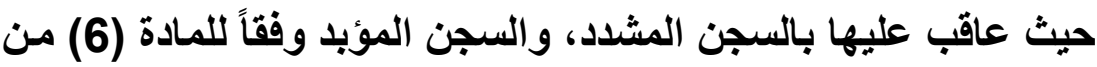

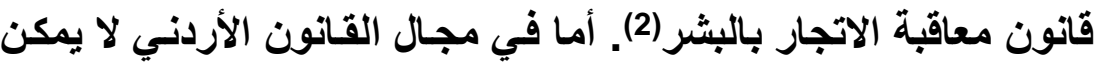

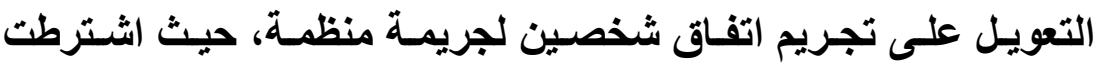

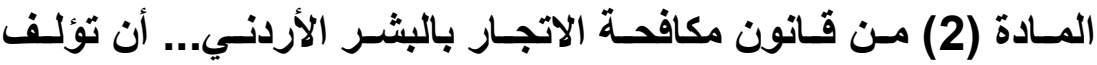

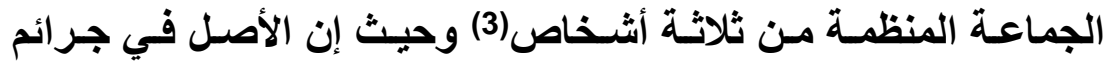

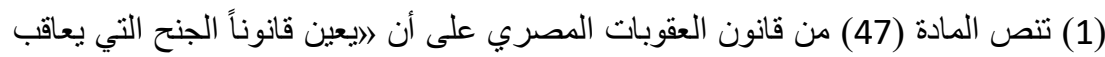

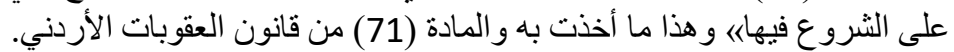

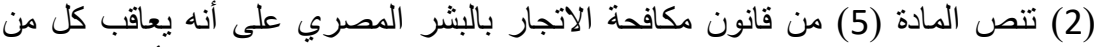

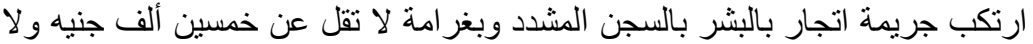

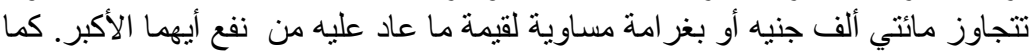

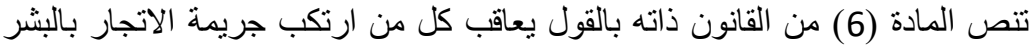

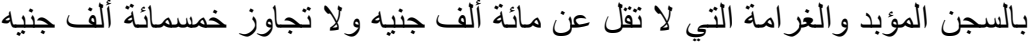

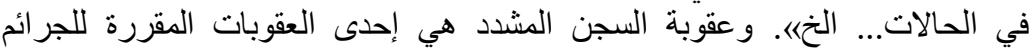

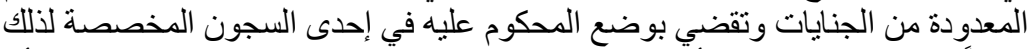

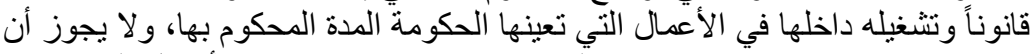

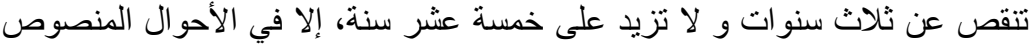

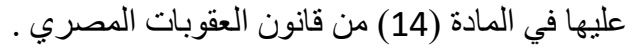

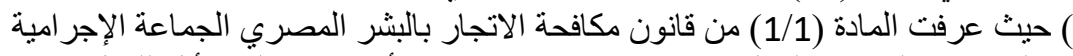

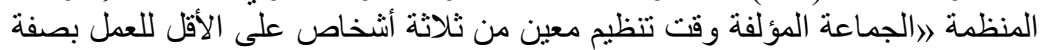

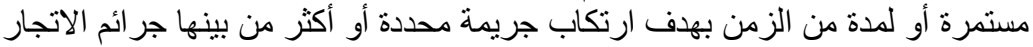

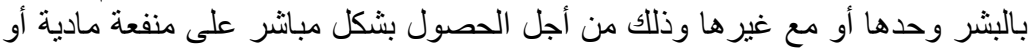


الاتجـار بالبشر ووفقاً للمـادة (8) مـن قـانون مكافحـة الاتجـار بالبشر

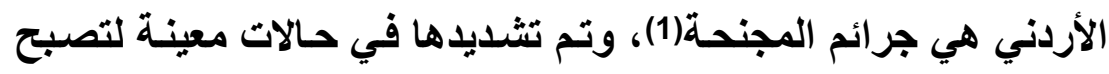

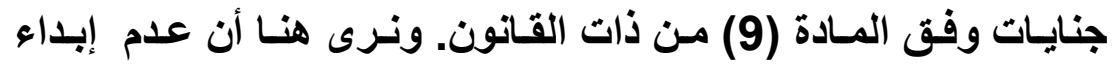

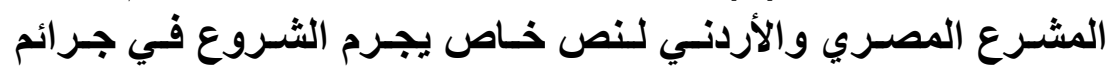

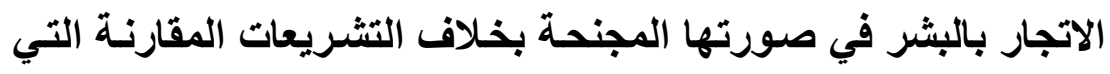

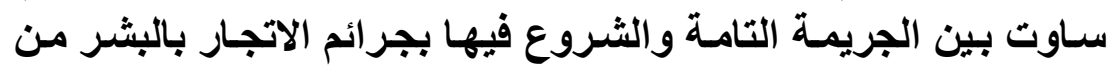

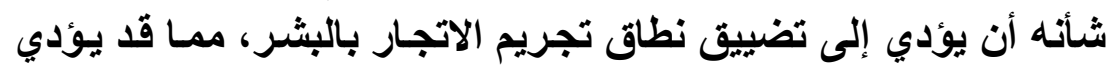

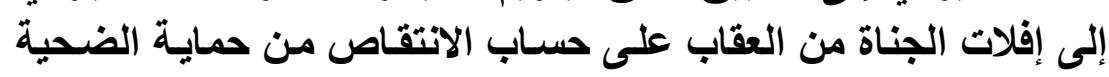

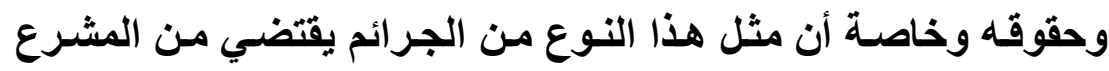

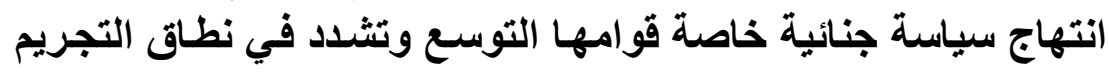

بسبب طبيتها الخاصة (2).

رابعاً: ضمانة الظروف المشددة للعقوبة

تعرف الظروف المشددة بأنها تلك الظروف المحددة بالقانون

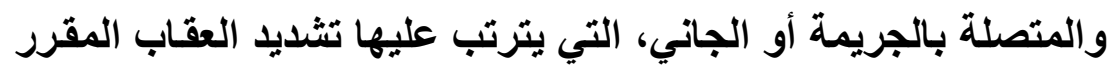

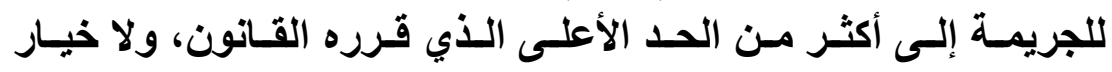

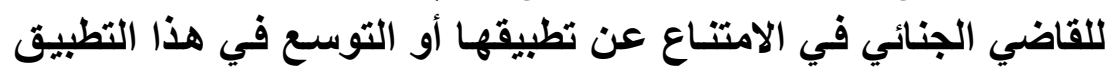
في غير الحالات التي حددها القانون(3).

معنوية، وبهذا المعنى نصت المادة (2) من قانون منع الاتجار بالبشر الأردني رقم (9) لسنة 2009.

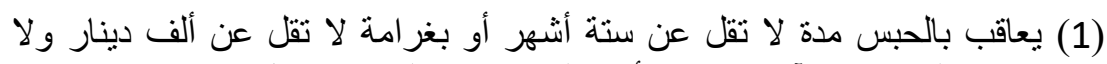

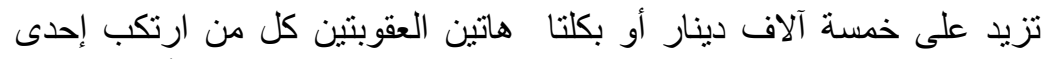

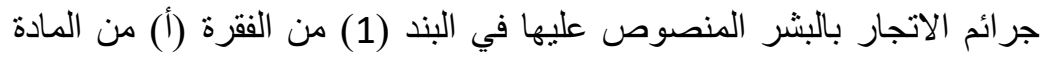
(3) من هذا القانون.

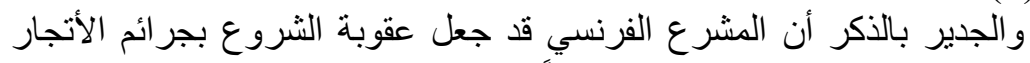

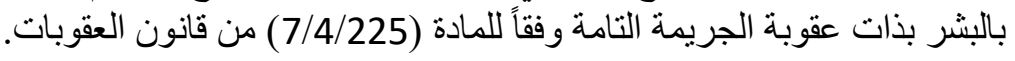

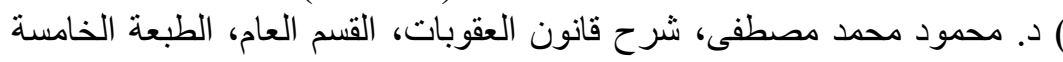

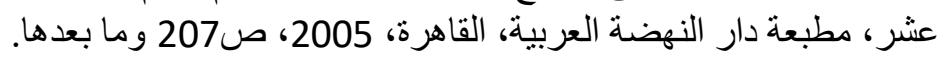




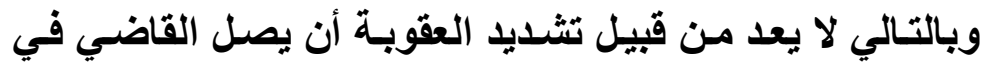

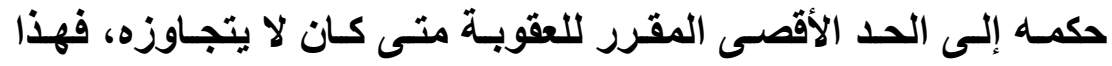
الحكم يعد ضمن السلطة التقليرية للقاضي(1).

وتنقسم هذه الظروف إلى نـوعين، الظروف المشددة العامـة

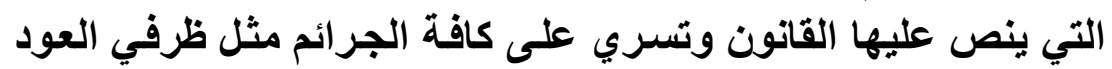

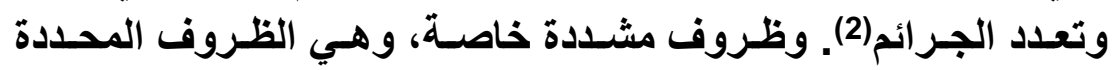

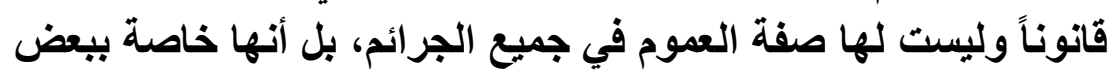
الجرائم خلافاً للظروف المشدادة العمدة في جميع.

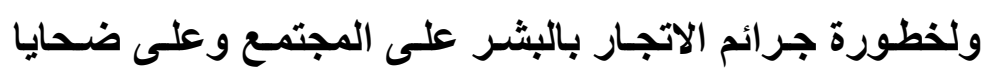

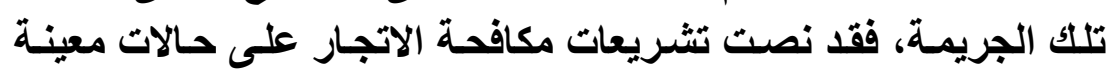

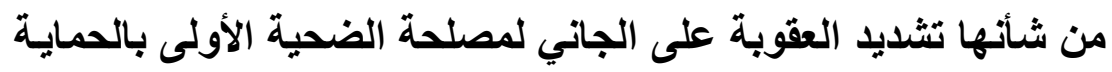

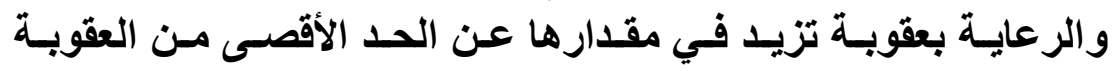
الأصلية لجريمة الاتجار.

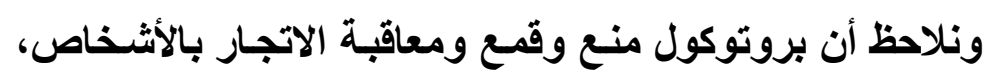

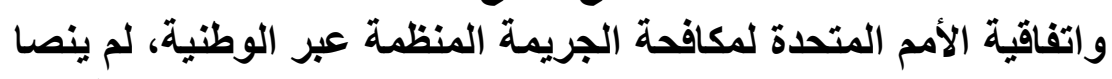

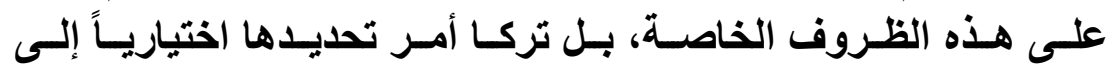

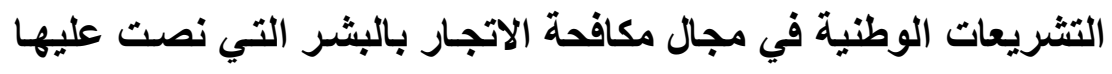

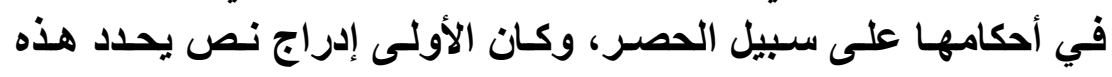
الظروف ضمن أحكامهما.

وبالرجوع إلى نصوص التثريعات العربيـة في مجال مكافحـة

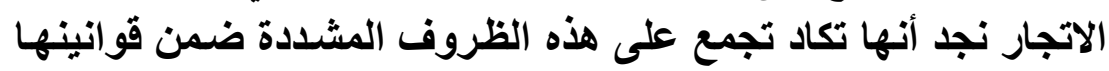

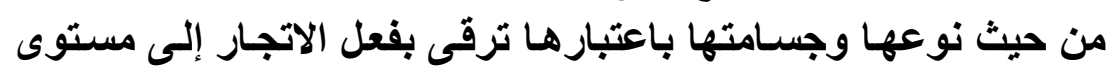

د. حاتم حسن بكار، سلطة القاضي الجنائي، منشأة المعارف، الإسكندرية،

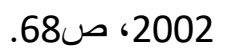

(2) يقصد بالعود ارتكاب المتهم جريمة جديدة رغم سبق الحكم عليه بعقوبة عن

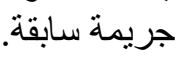

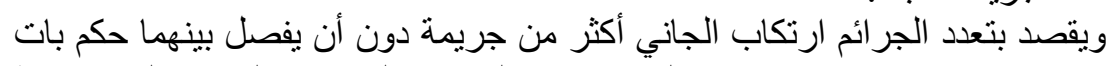

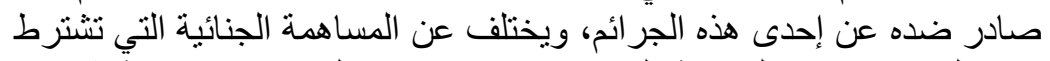

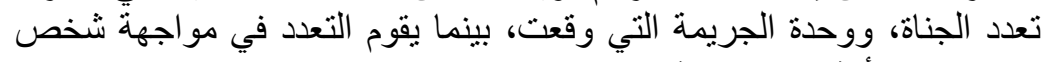
واحد ارنكب أكثر من جريمة. 
الجنايـة وإن كانت تختلف بمقدار العقوبـة المقررة مـن حيث مــتها و الغرامة المفروضة عليها.

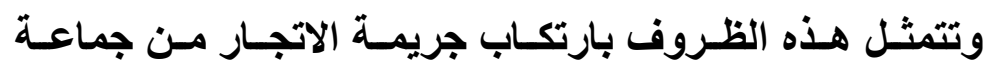

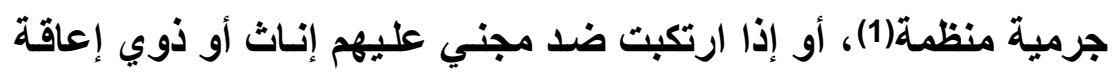

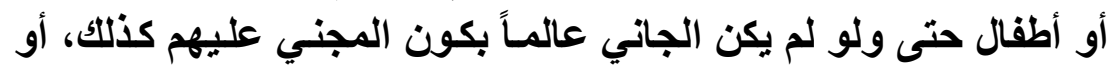

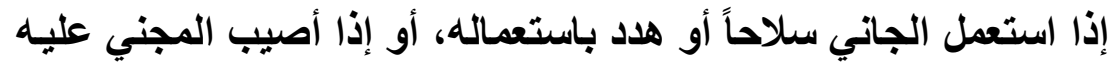

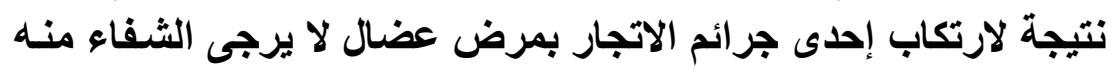

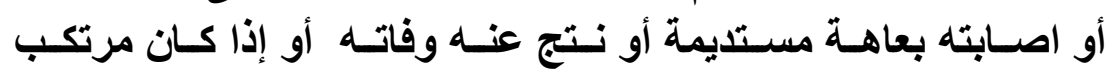

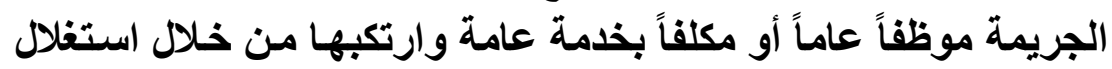

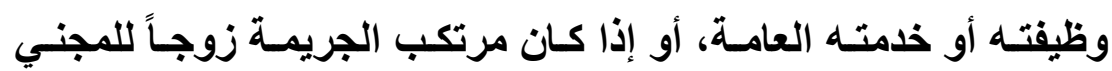

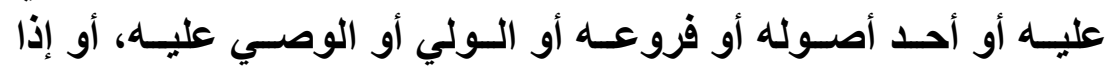

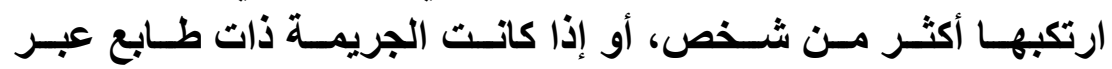

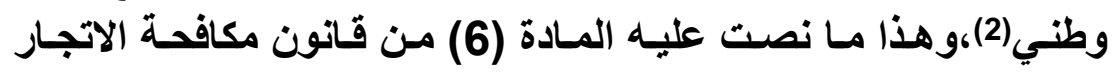

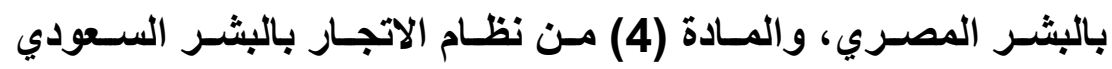

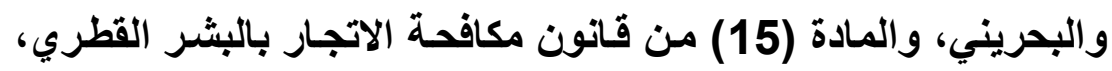

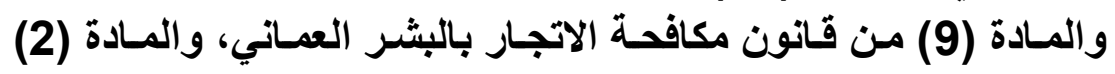

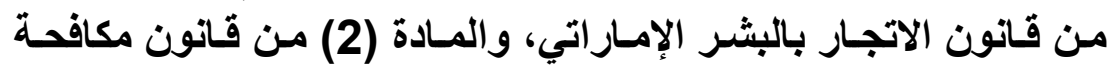
الاتجـار بالأثخاص الكويتي، والمـادة (6) من قانون مكافحـة الاتجـار

(1) تعرف اتفاقية الأمم المتحدة لمكافحة الجريمة المنظمة: الجماعة الإجرامية المنظمة وفقاً

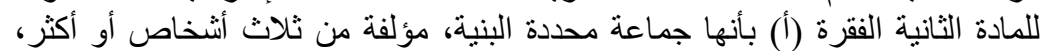

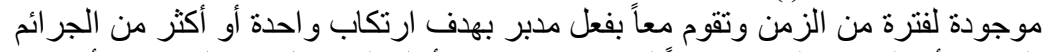

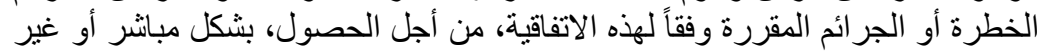

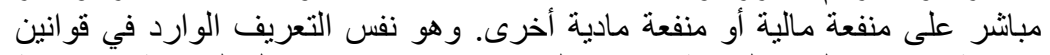

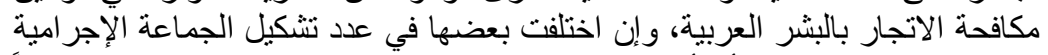

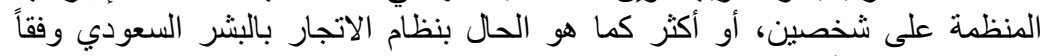

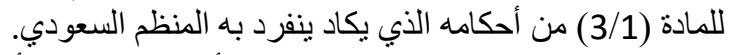

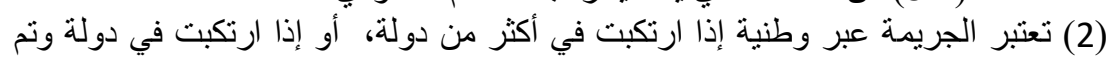

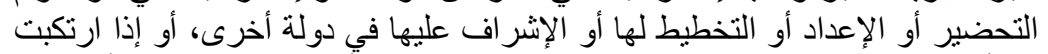

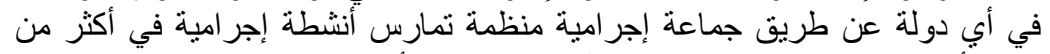

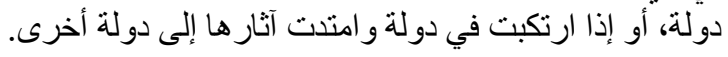


بالبشر العراقي،والمادة (4/586) من قانون العقوبات اللبناني، والمادة (9) من قانون مكافحة الاتجار بالبشر الأردني(1).

وفي هذا المجال نجد أن المشرع السوري قد انفرد بالنص على المئ

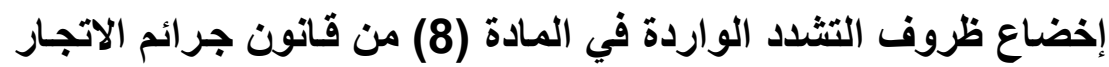

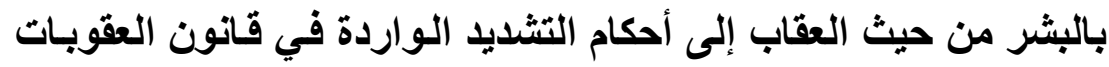

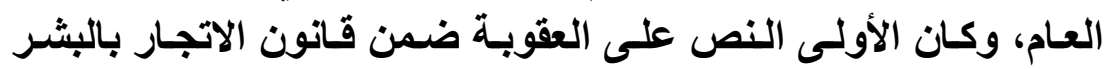

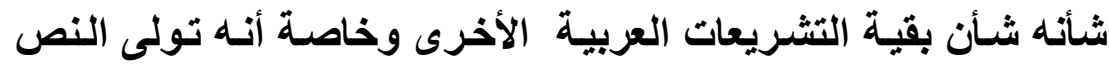

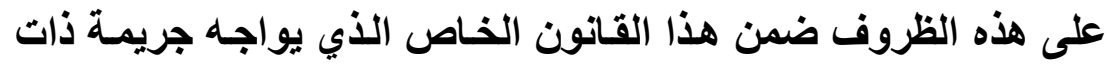

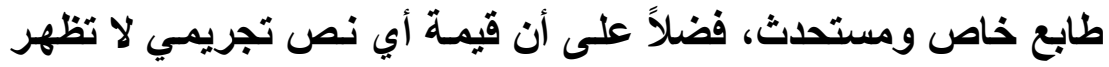
إلا بالنص على العقاب فيه.

وباستقراء الظـروف المشـدادة للعقوبـة في الحسالات السـابقة

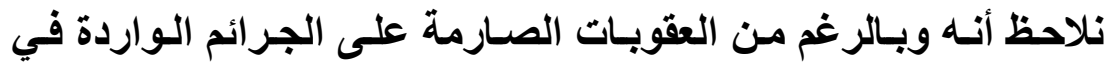

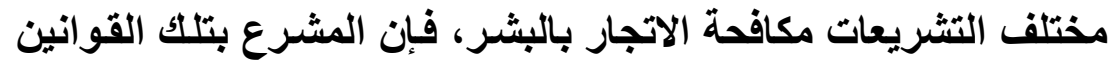

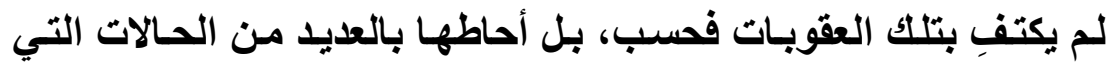

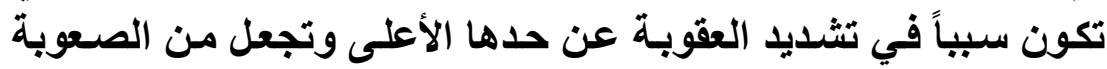

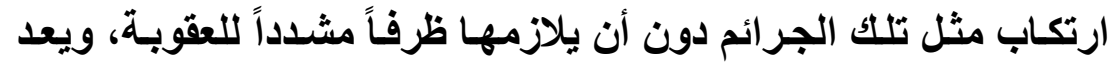

(1) تثندد العقوبة على الجاني بالقانون الصصري بالسجن المؤبد والغر امة التي لا تقل

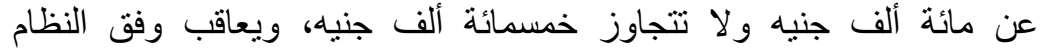

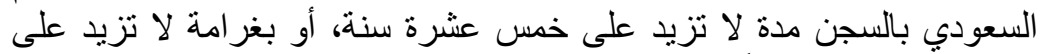

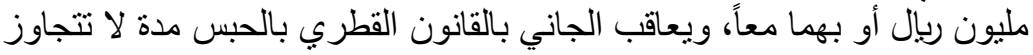

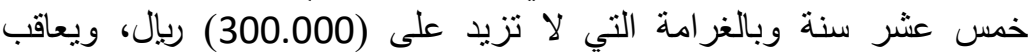

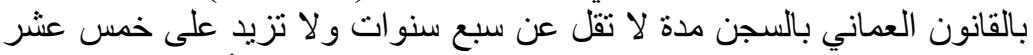

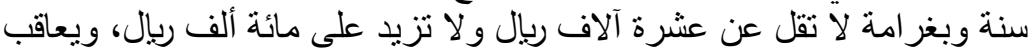

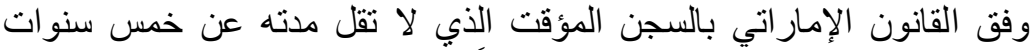

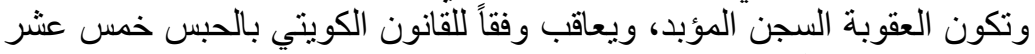

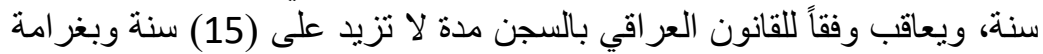

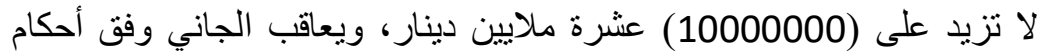

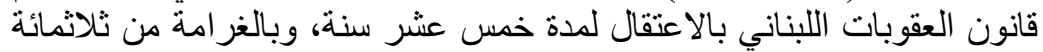

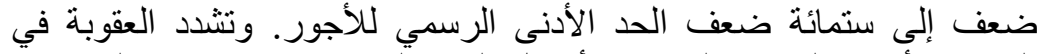

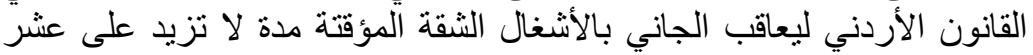
سنوات وبغرامة لا تقل عن خمسة آلاف دينار و لا تزيد على عشرين ألف دينار. 
(1) أورد المشرع الفرنسي حكماً في المادة (5/4/225) من قانون العقوبات يكون

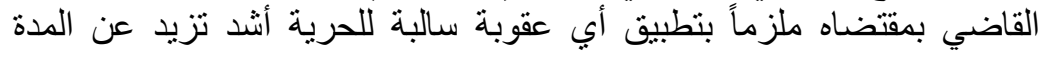

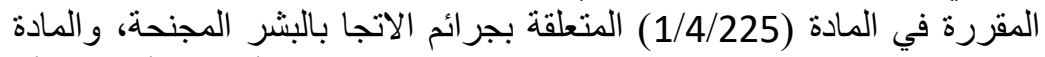

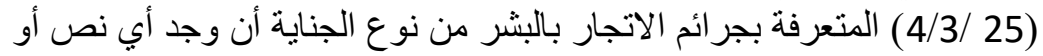

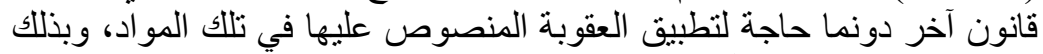

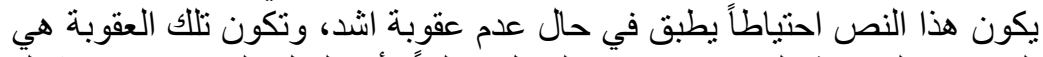

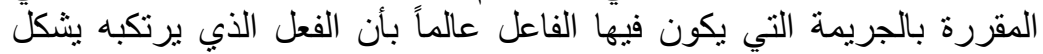
اتجار بالبشر بالجر

Article 225-4-5 Lorsque le crime ou le délit qui a été commis ou qui devait être commis contre la personne victime de l'infraction de traite des être humains est puni d'une peine privative de liberté d'une durée supérieure á celle de l'emprisonnement encouru en application des articles 225-4 1-á 225-4-3 l'infraction de traite des être humains est punie des peines attachées aux crimes ou aux délits don't son auteur a eu connaissance et, si ce crime ou délite est accompagné de circonstances aggravantes, des peines attachées aux seules circonstaces aggravantes don't il a eu connaissance.

و هذا ما تبناه المشرع الأمريكي في البند (1589، 1590) من قانون حماية ضحايا

$$
\text { الاتجار بالأشخاص لعام } 2000 \text {. }
$$

نص المشرع الأمريكي في البند (1589) من قانون لإند حماية ضحايا الاتجار

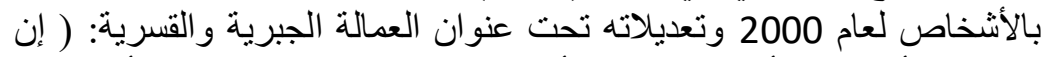

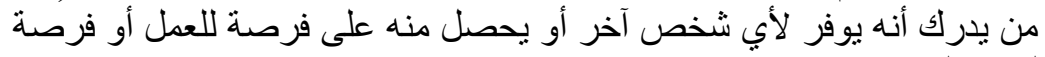
لتقديم الخدمات:

أـ عن طريق تهديد هذا الشخص أو تهديد شخص آخر بإلحاق الضرر به أو أو أونات

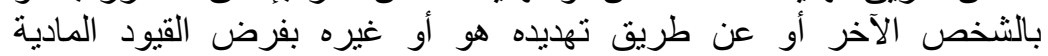

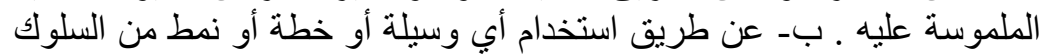

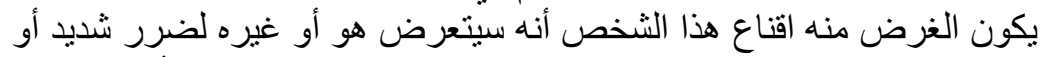

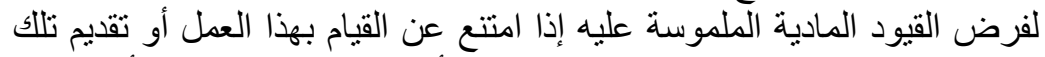

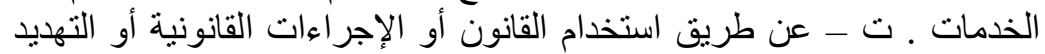

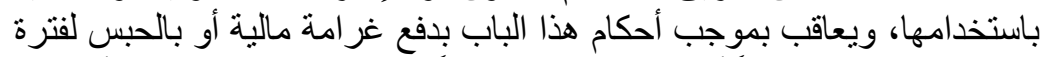

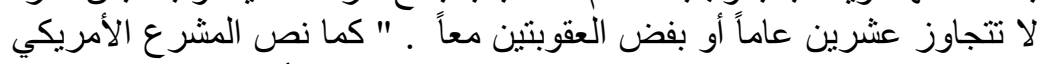
في البند (1590) من قانون حماية ضحايا الاتجار بالأشخاص لعاص لعام 2000

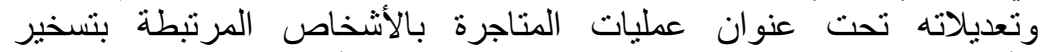

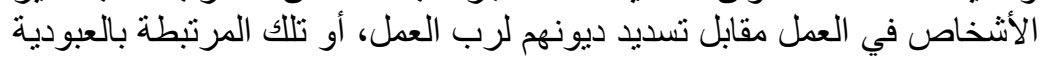

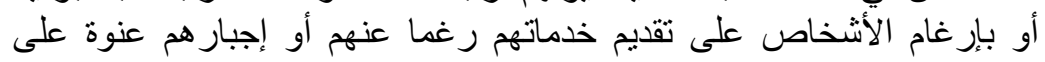




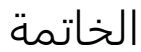

العمل : "أن من يقوم بتجنيد أو إيواء أو نقل أو توفير شخص أو الحصول عليه

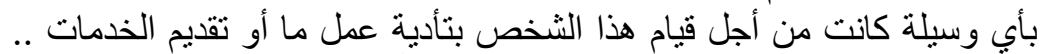

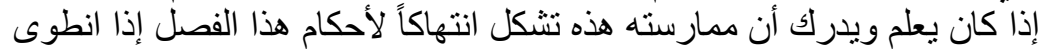

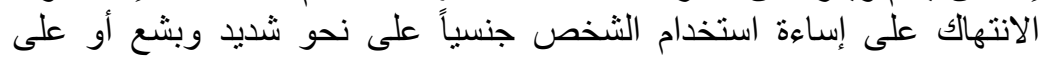

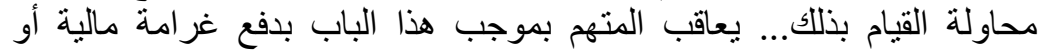
بصدور حكم ضده بالسجن المؤيد أو السجن لأي عدد من السنوات، كما يجوز فرض العقوبتين معاً. - - نص المشرع الأمريكي في البند (1590) من قانون حماية ضحايا الاتجار

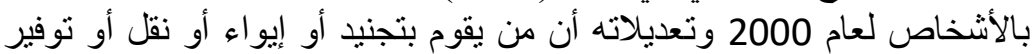

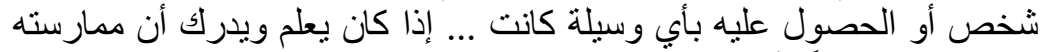
هذه تشكل انتهاكاً لأحكام هذا الفصل إذا إذا انطوى الانتهاك على على إساءة استخدام

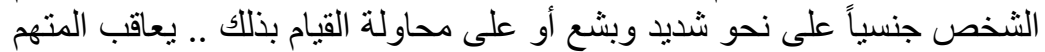

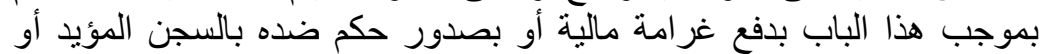

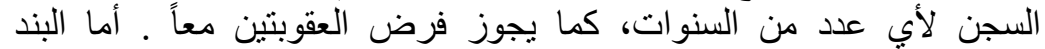

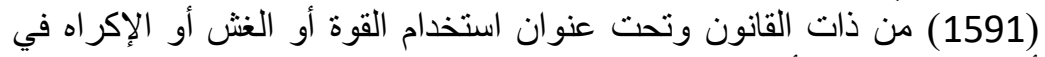

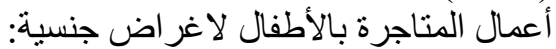

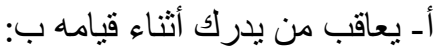

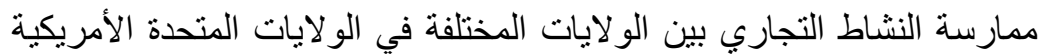

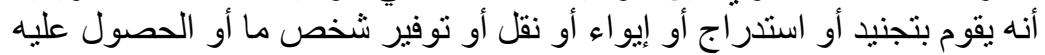

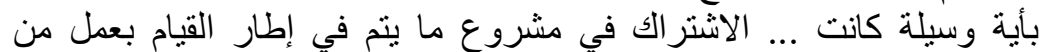

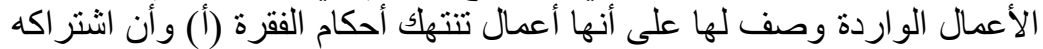

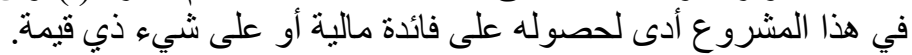

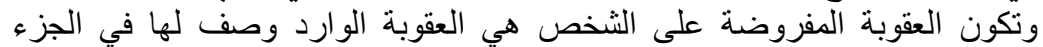

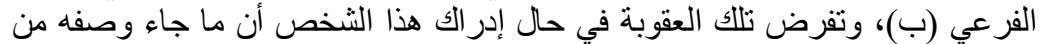

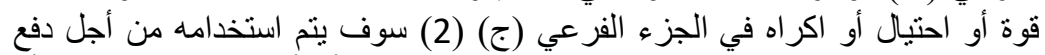

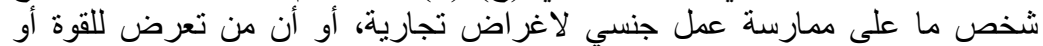

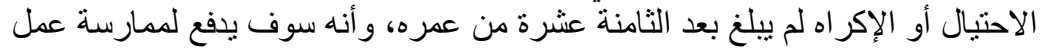

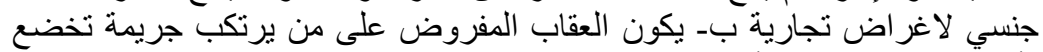
لأحكام الجزء الفرعي (أ):

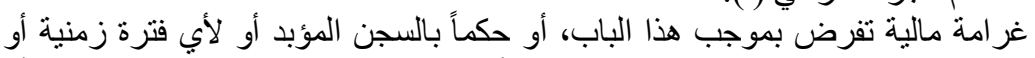

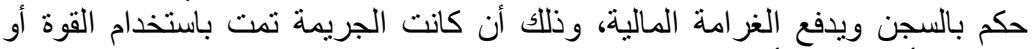

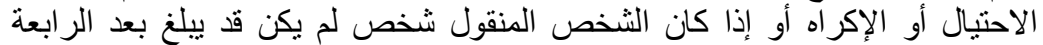

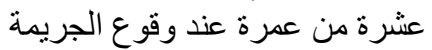

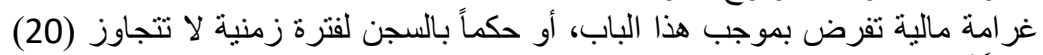

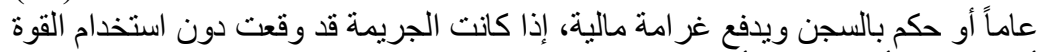

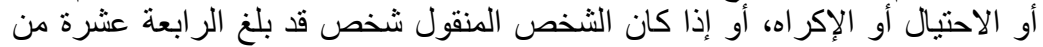
عمرة عند ارتكاب الجريمة ولكنه لم يبلغ بعد الثامنة عشرة من عمره. 
توصلنا في ختام هذا البحث إلى جملة من النتائج والتوصيات

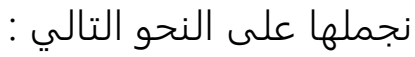

$$
\text { أولاً:- النتائج }
$$

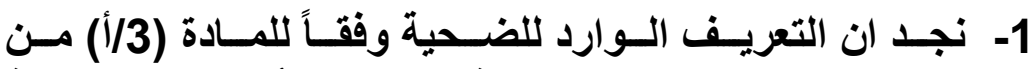

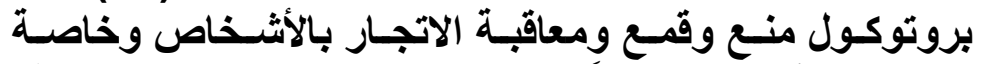

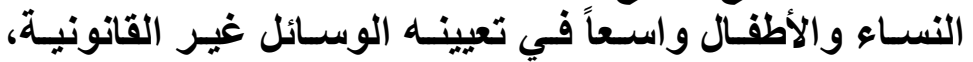

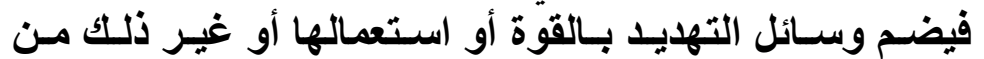

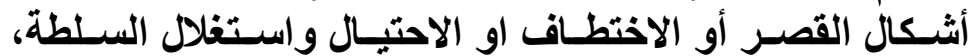

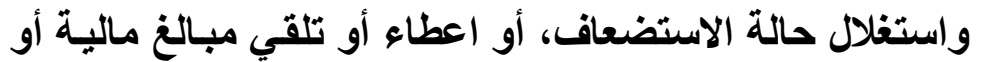

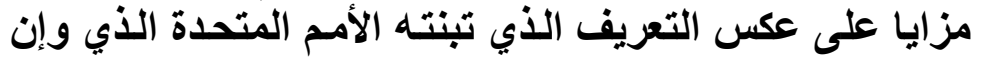

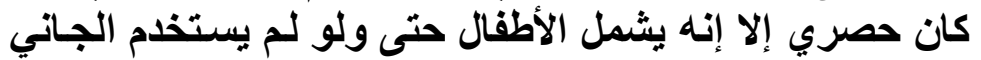

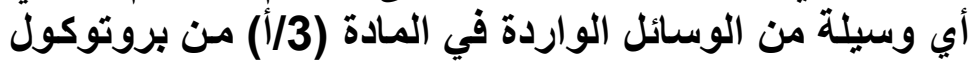

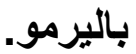

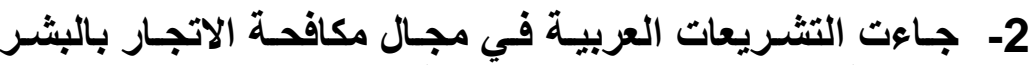

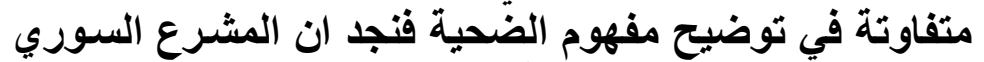

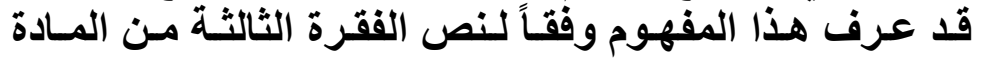

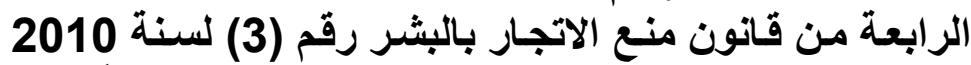

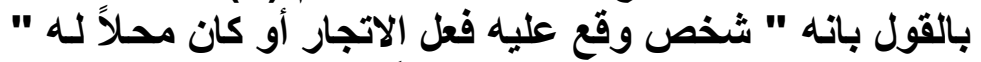

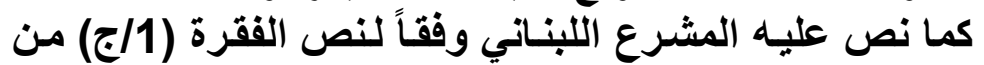

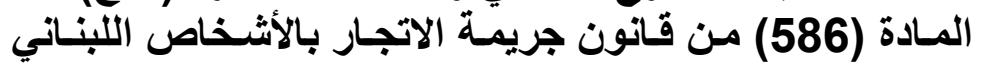

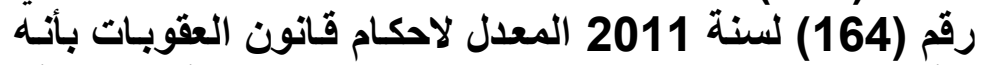

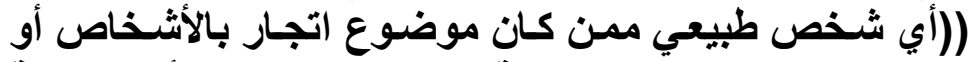

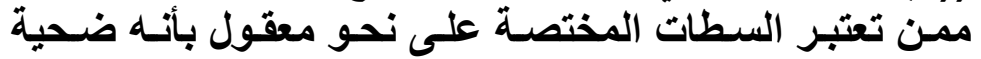

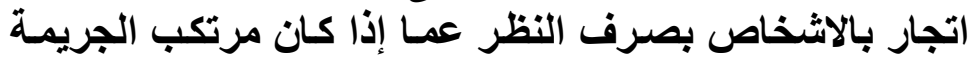

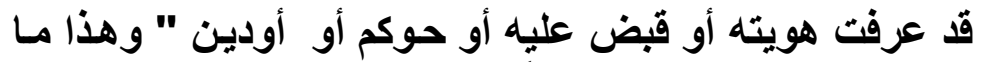

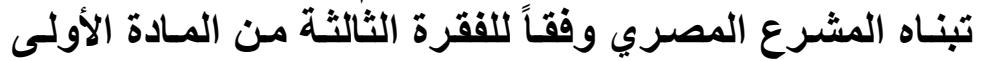

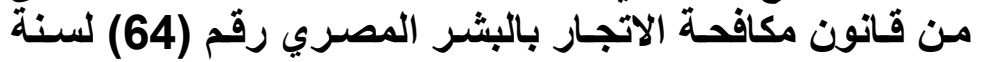

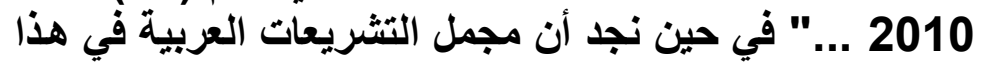

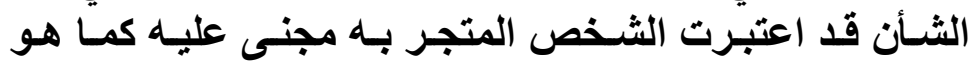

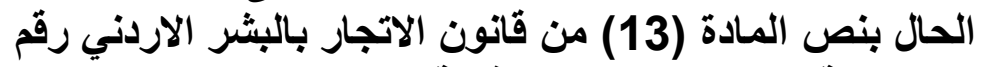

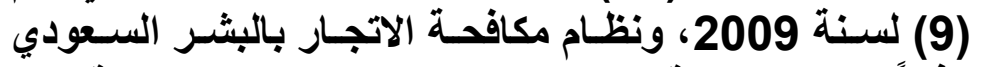

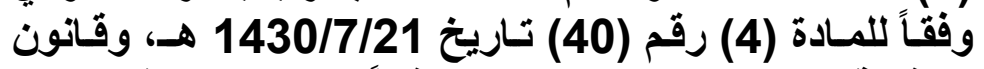

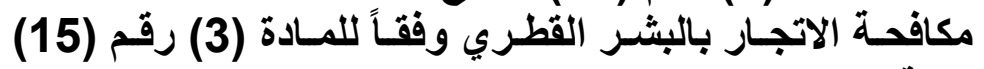




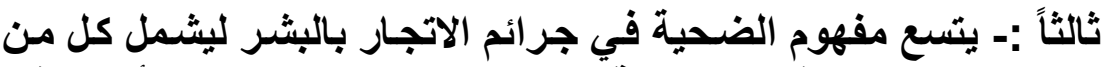

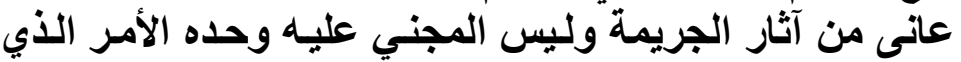

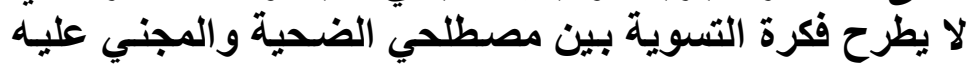

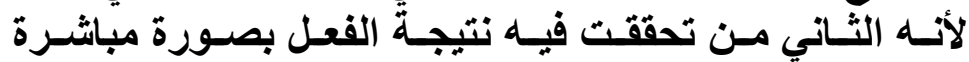

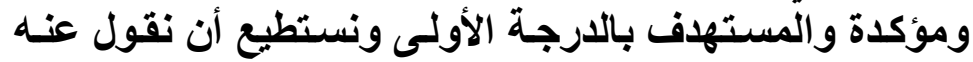

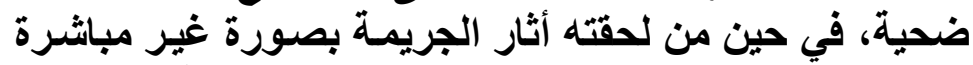

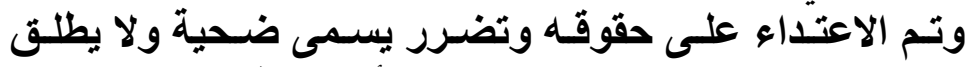

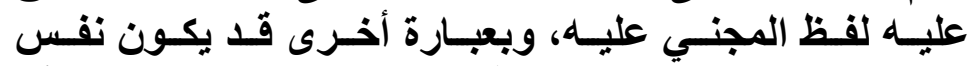

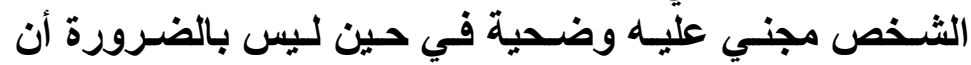
يكون المجني عليه ضحية في جريمة الاتجار بالبشر. بالضرو

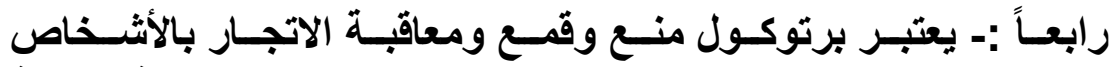

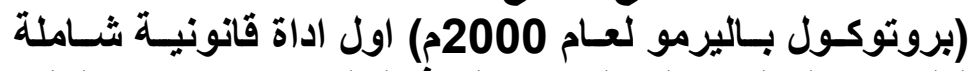

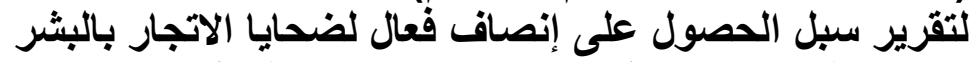

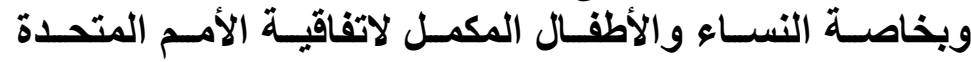

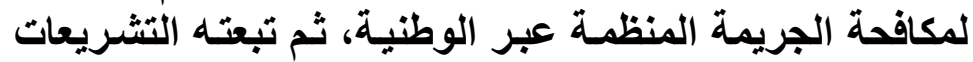

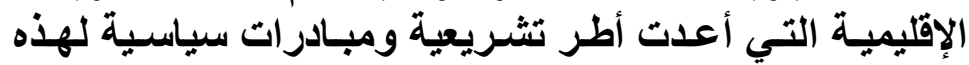

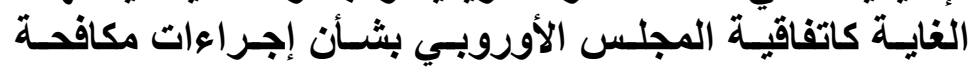

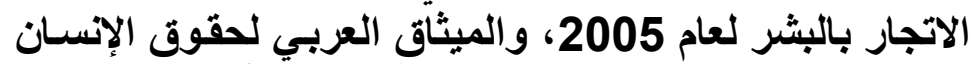

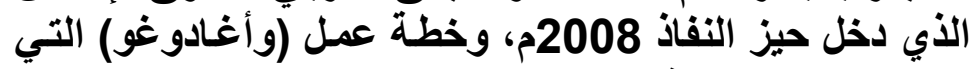

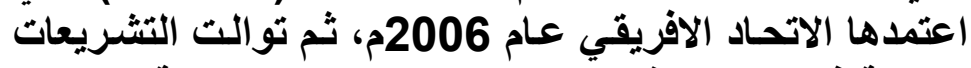

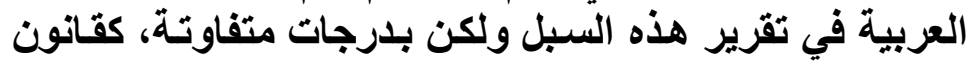

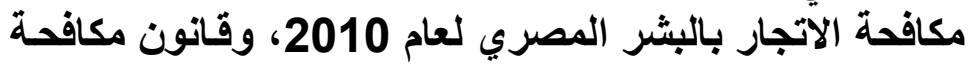

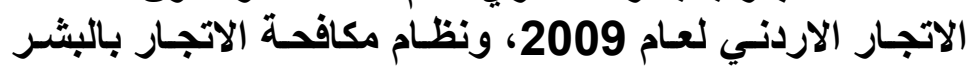

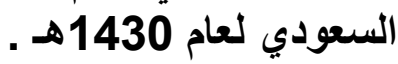

خامسـاً :- هنالك مؤشـرات عامـة للتعرف على ضحية الاتجـار بالبثر

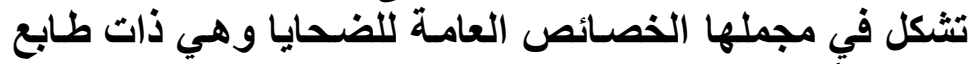

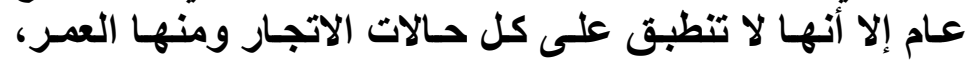

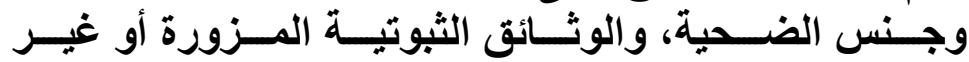

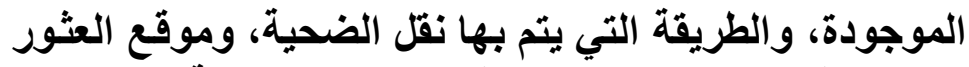

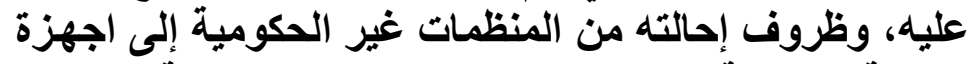

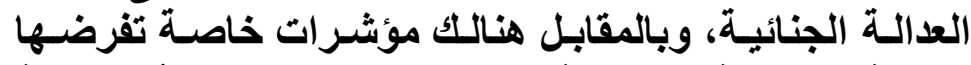

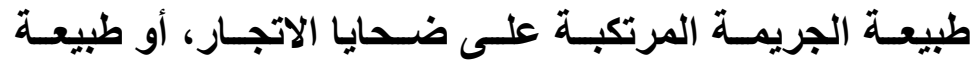

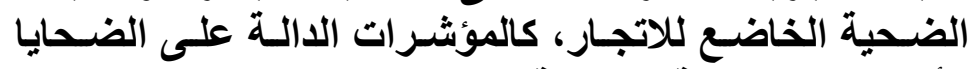

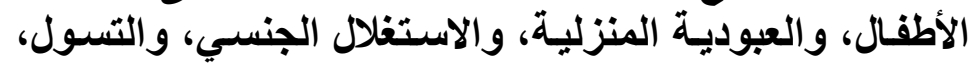

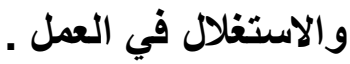




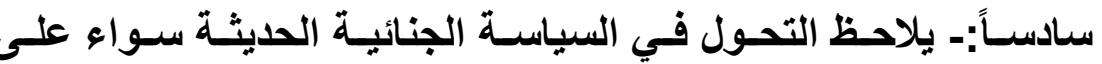

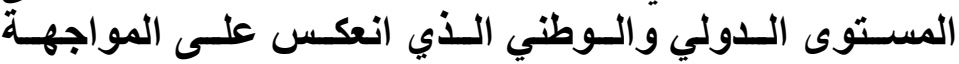

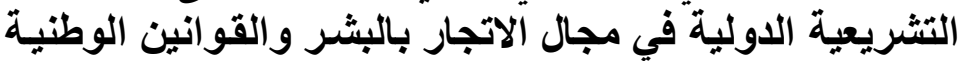

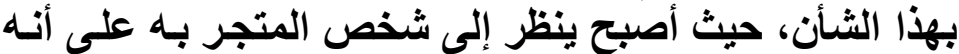

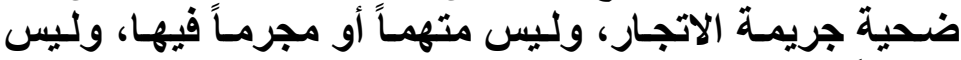

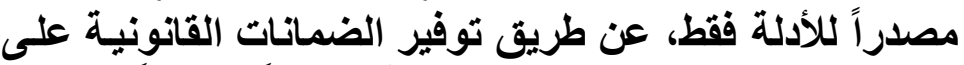

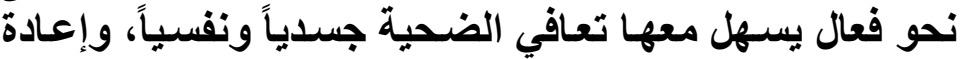

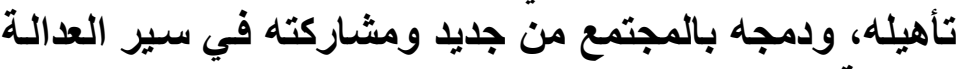

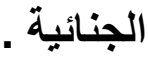

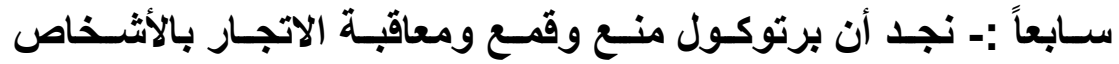

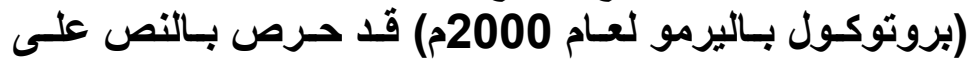

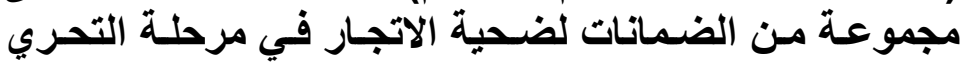

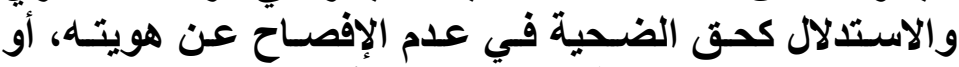

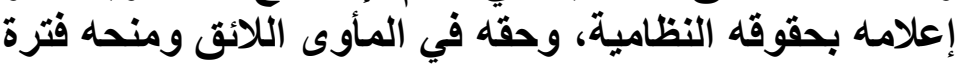

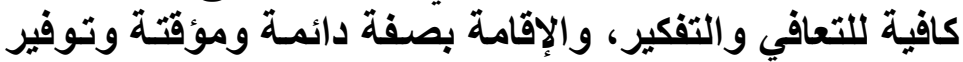

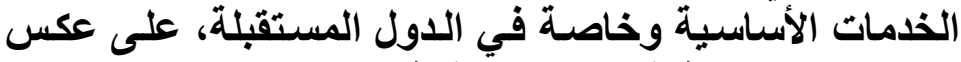

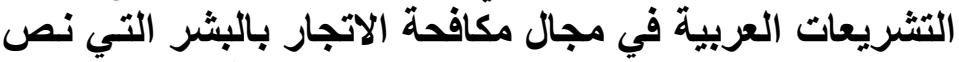

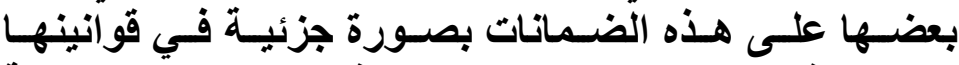

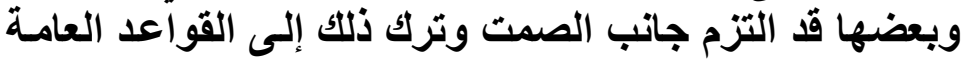
لقانون الإجراعات الجنائية .

ثامناً :- إن من حق ضحايا الاتجار بالبشر في مرحلة التحقيق الابتدائي

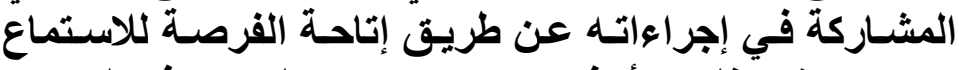

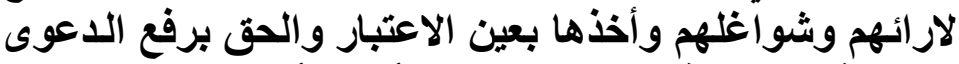

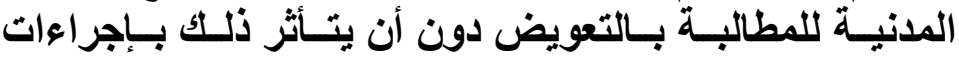

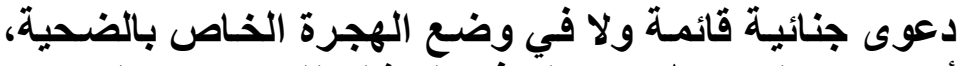

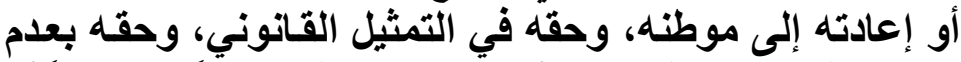

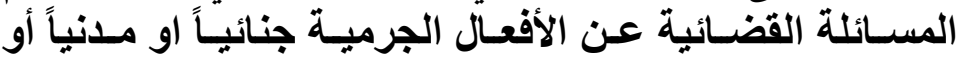

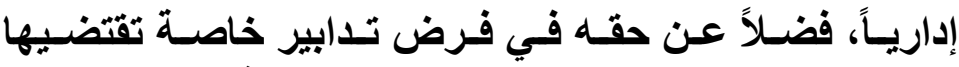

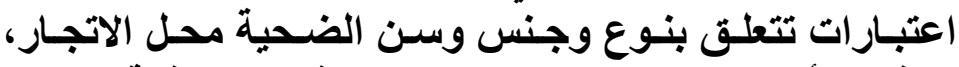

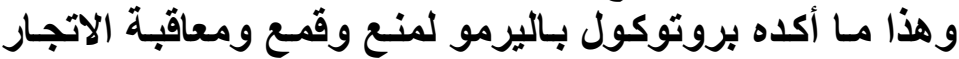

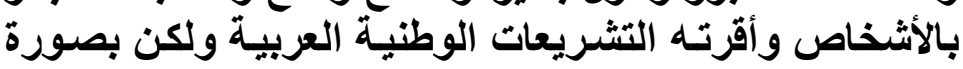
متفاوتة في أحكامها .

تاسـعاً:- نلاحظ أن برتوكـول بـاليرمور لمنـع وقــع ومعاقبـة الاتجـار

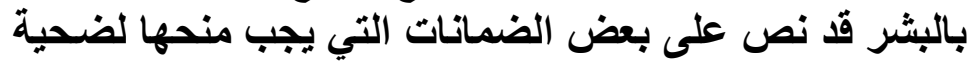




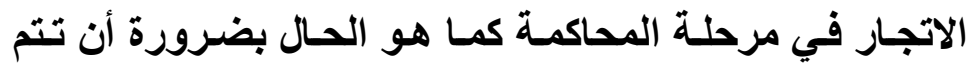

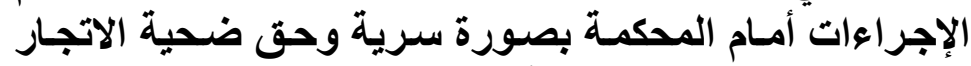

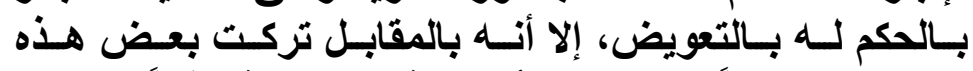

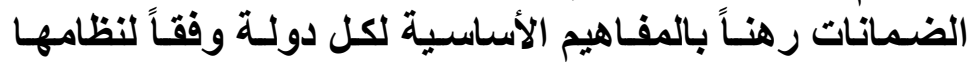

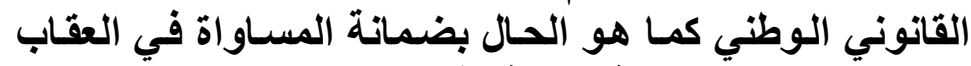

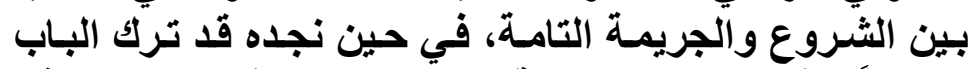

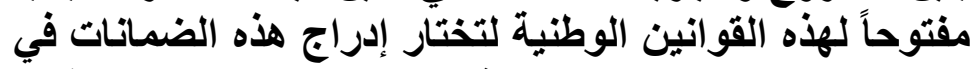

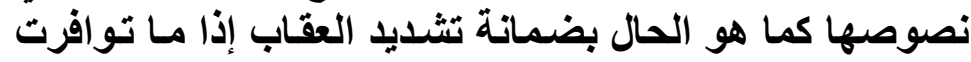

$$
\text { أحد الظروف المشددة . أهول }
$$

عاثراً :- نجد أن السياسـة العقابية التي انتهجتها التشريعات الوطنية

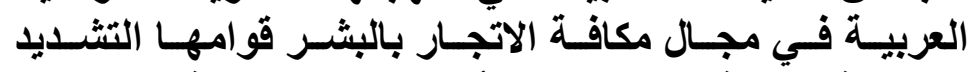

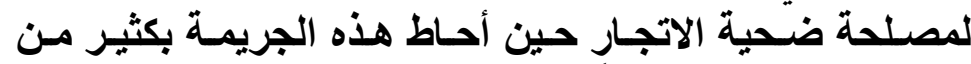

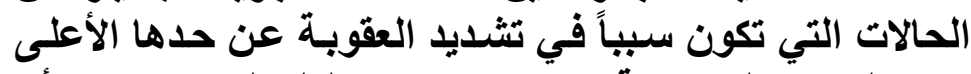

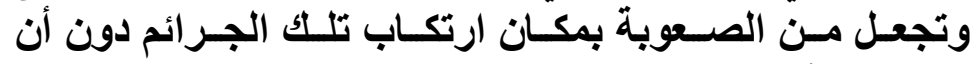
تلازمها هذه الظروف مـ الصوبة 


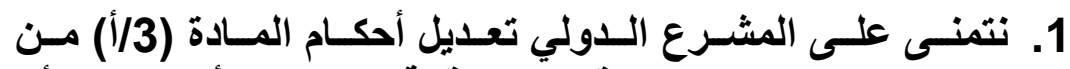

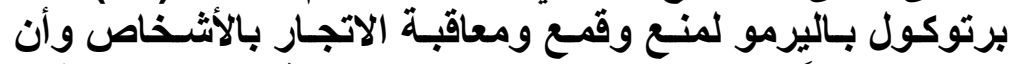

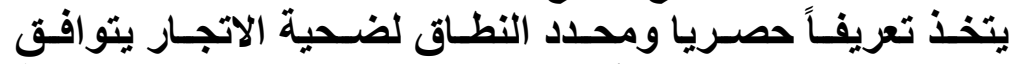

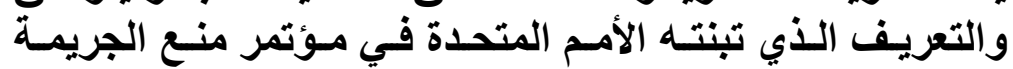

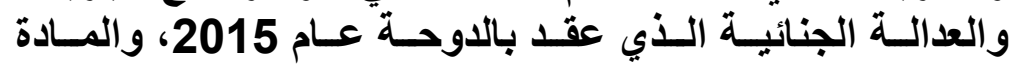

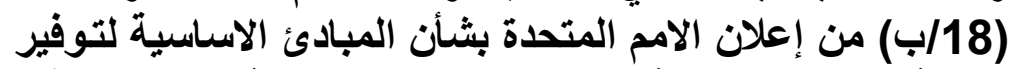

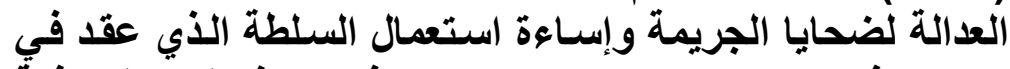

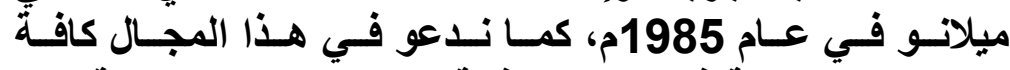

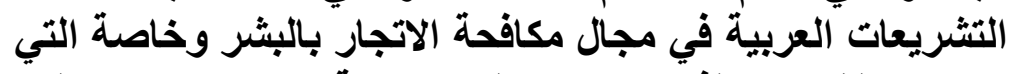

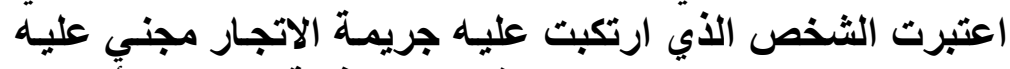

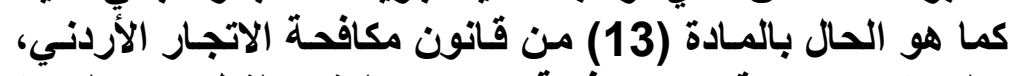

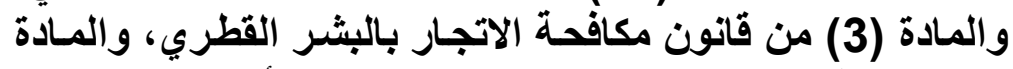

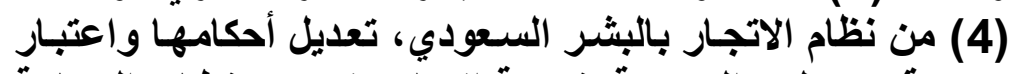

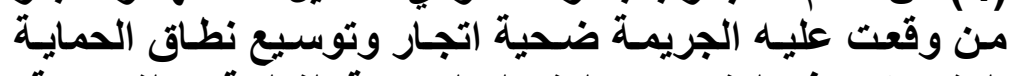

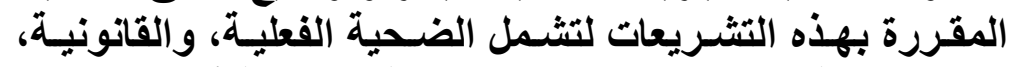

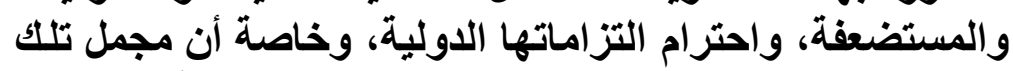

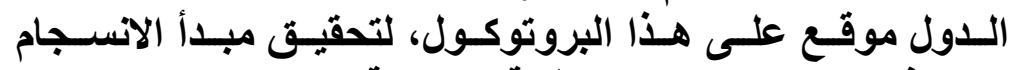

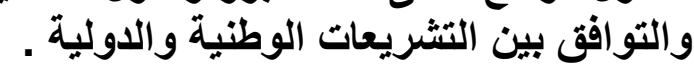

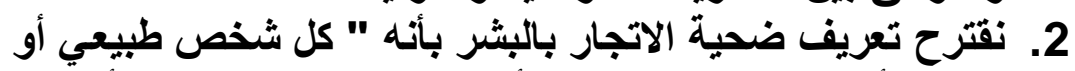

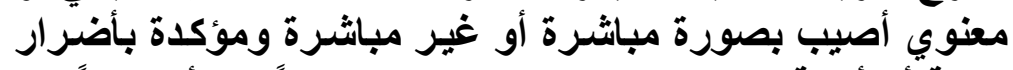

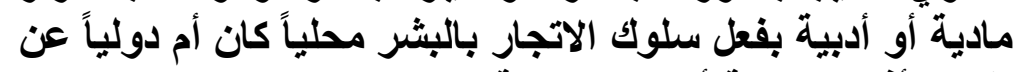

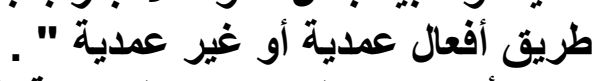

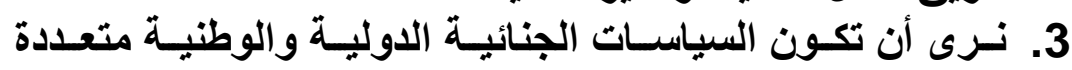

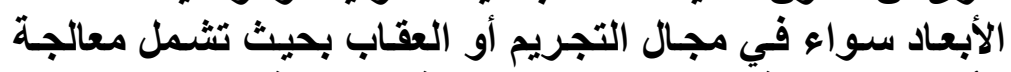

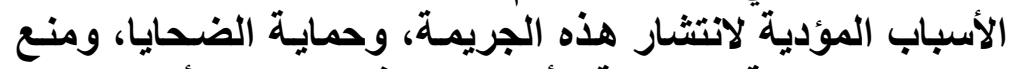

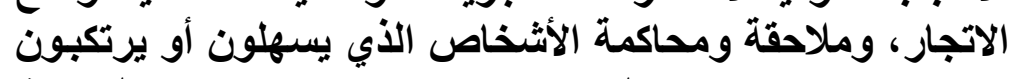

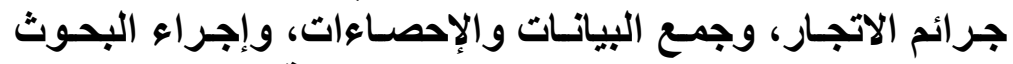

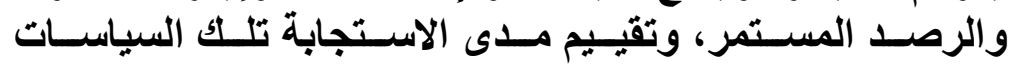
والتدابير.

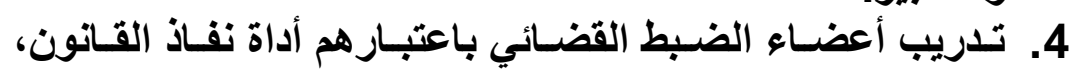

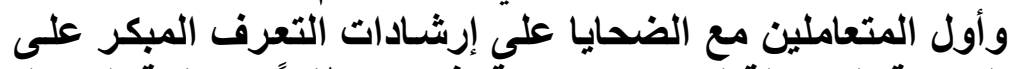

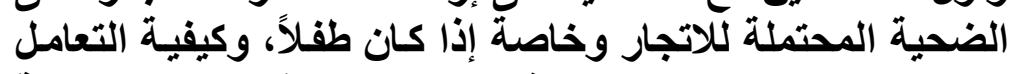

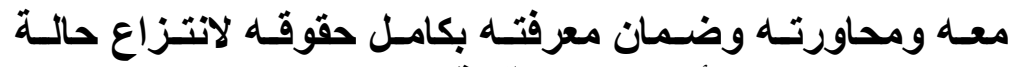

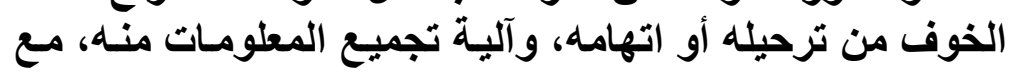


الأخذ بعين الاعتبـار عمـر الضـحية وحالته النفسية والصـية

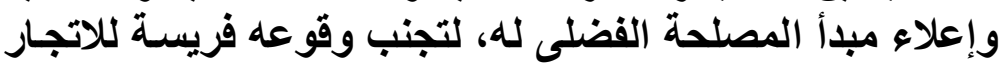
مرة أخرى خلال مرحلة المقابلة والتحقى التهن.

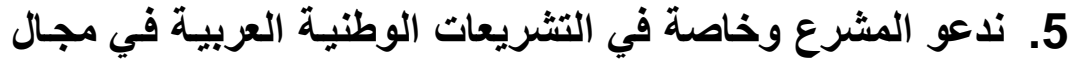

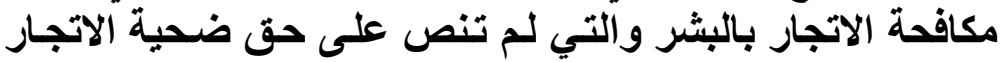

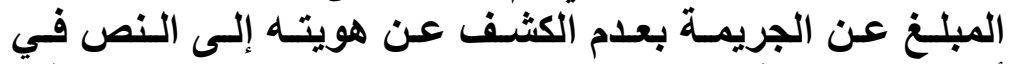

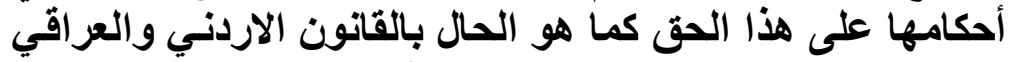

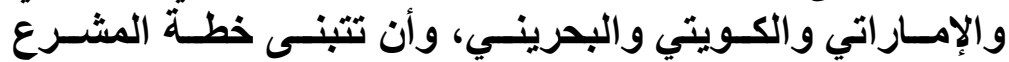

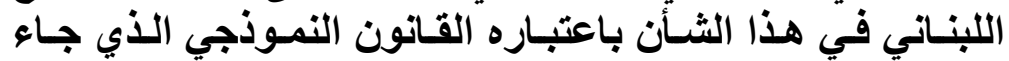

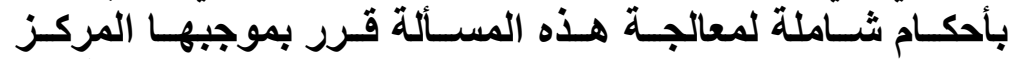

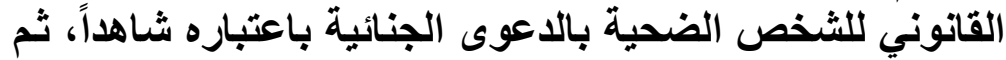

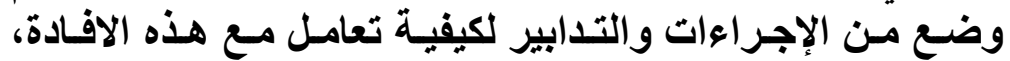

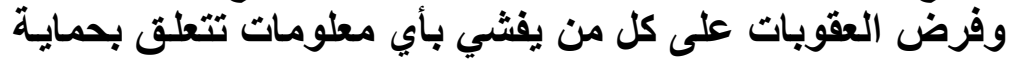

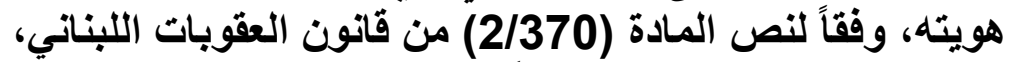

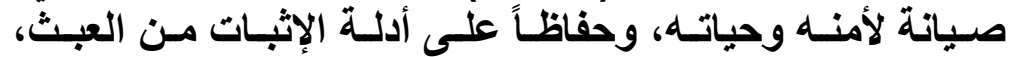

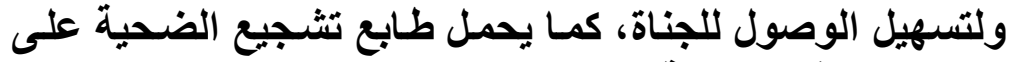
تبليغ عن هذه الجريمة . 6. نتمنى على المشرع هذه الدوريمة الدي أن يعيد النظر في خطته التشريعية

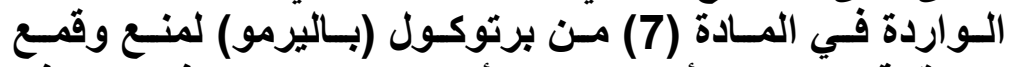

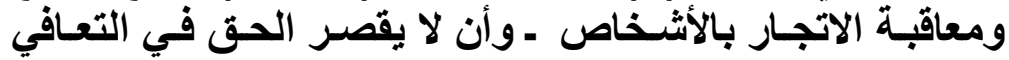

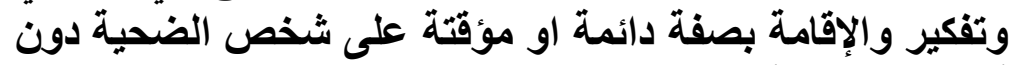

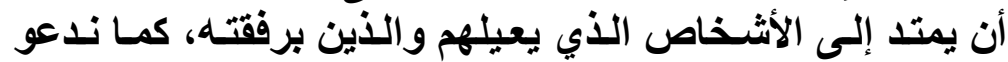

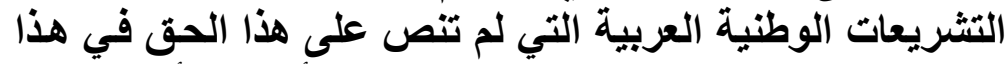

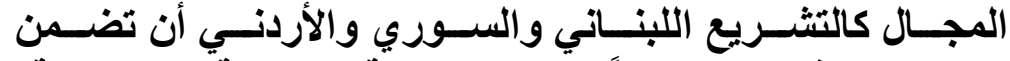

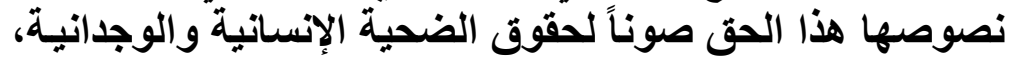

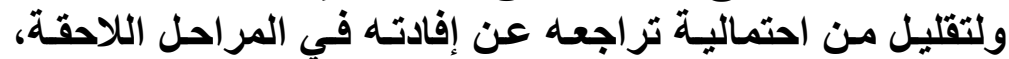

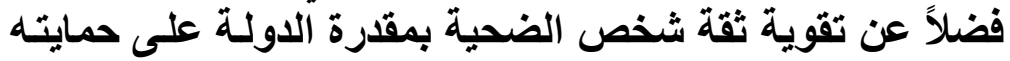
وصيانة حقوقه . 7. ضرورة استحداث نص في التشريعات العربية في مجال مكافحة

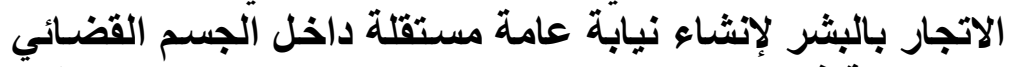

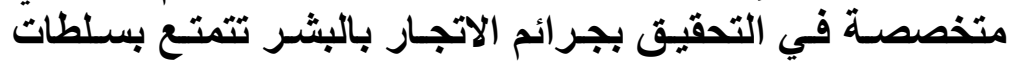

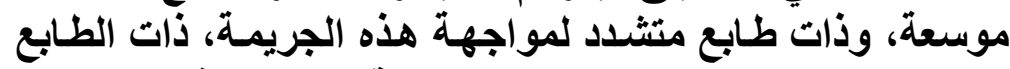

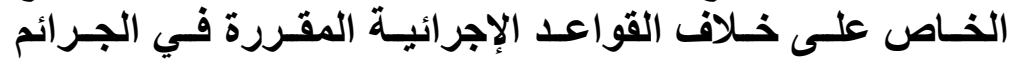

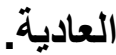

8. ندعو المشرع الدولي إلى تعديل بروتوكول باليرمو لمنع وقميع

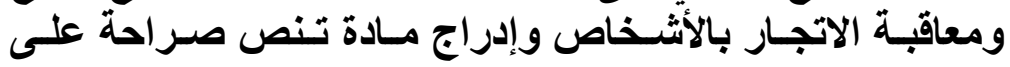




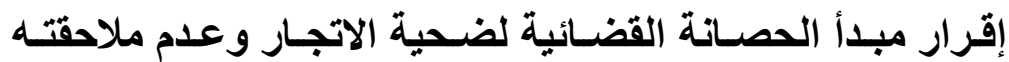

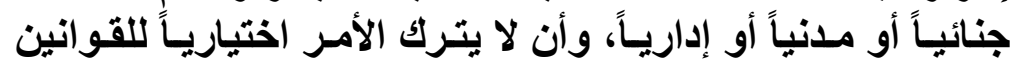

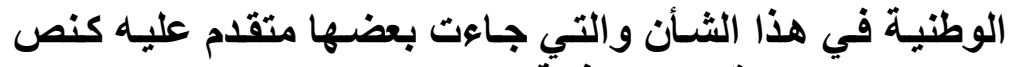

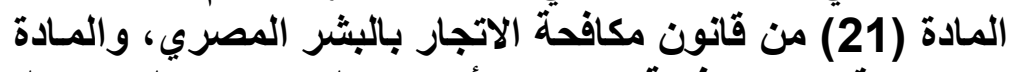

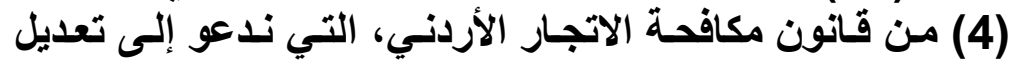

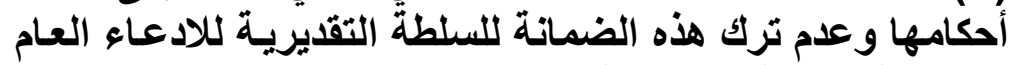

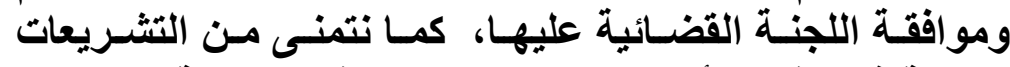

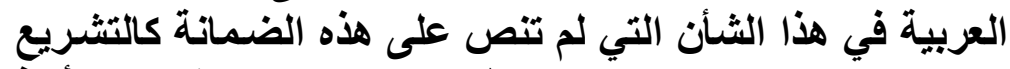

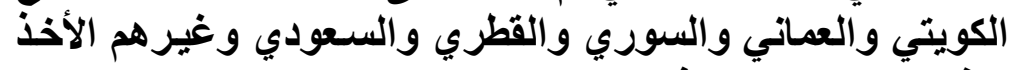

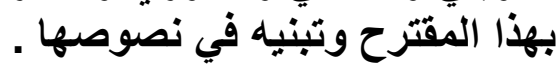

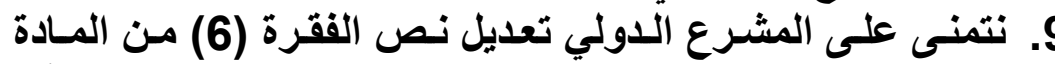

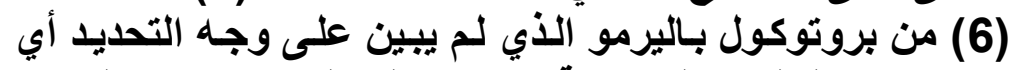

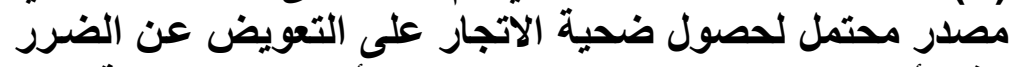

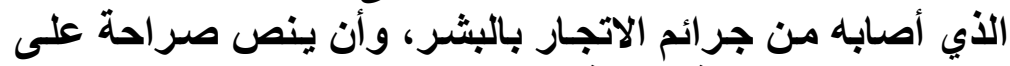

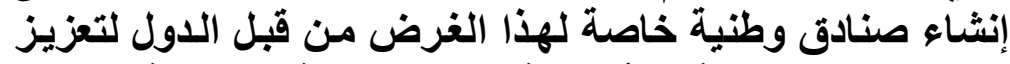

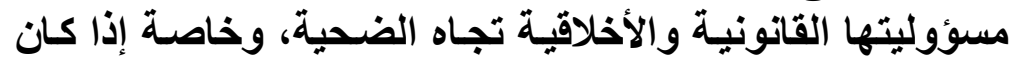

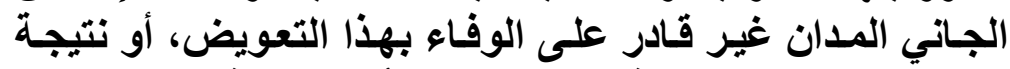

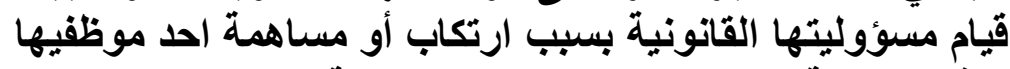

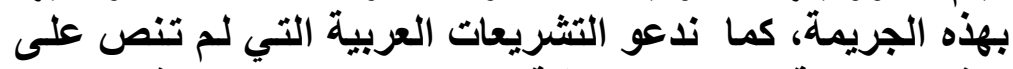

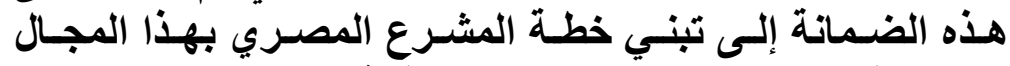

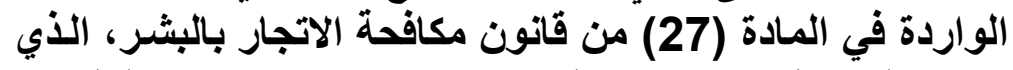

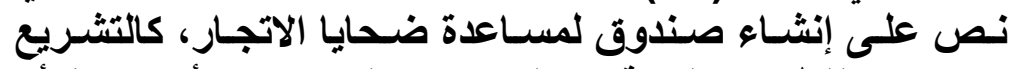

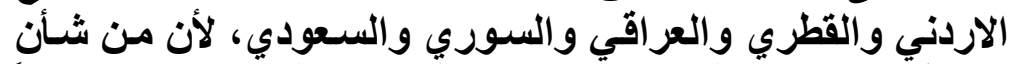

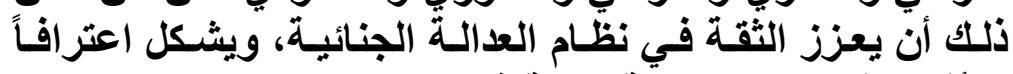

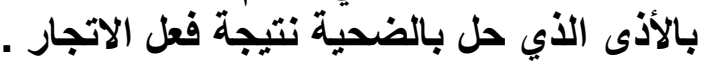

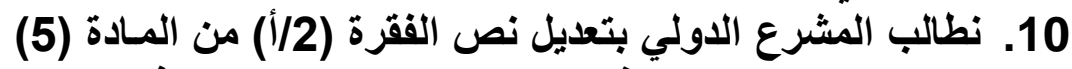

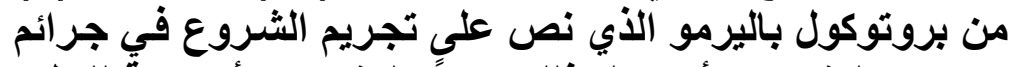

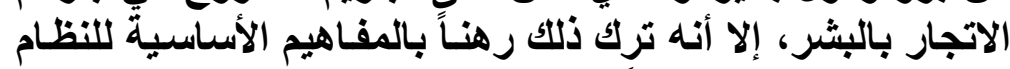

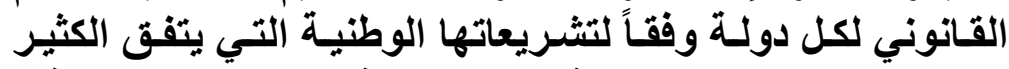

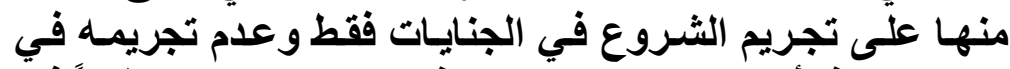

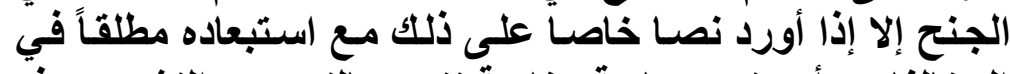

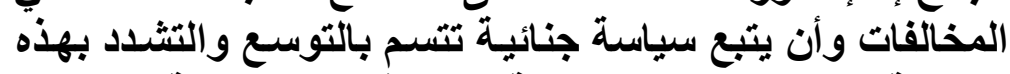

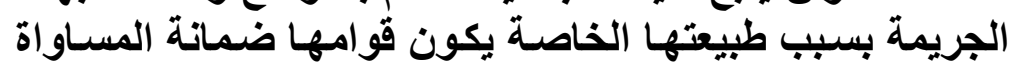

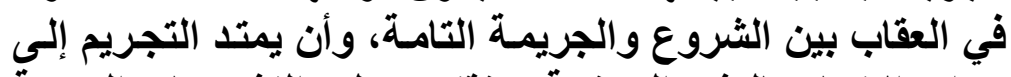

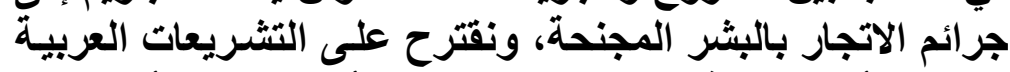

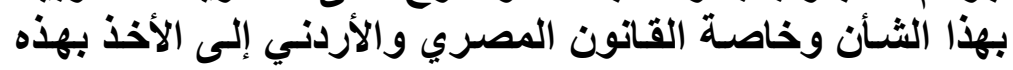




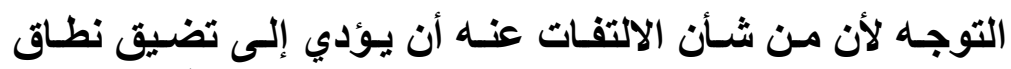

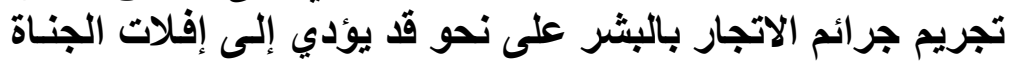
من العقاب على حساب الانتقاص من حقوق الضحية وحمايته . 


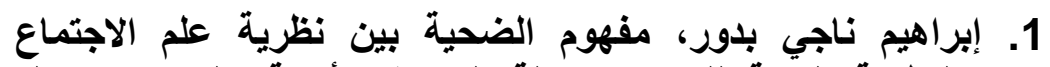
والنظرية العامة للتجريم، مجلة البحوث الأمنية، الرياض، مجلد الفئل

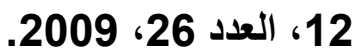

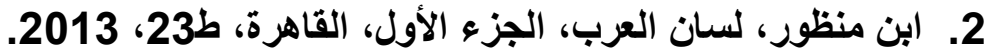

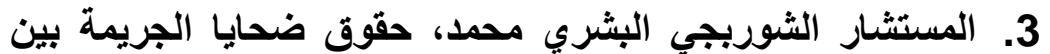

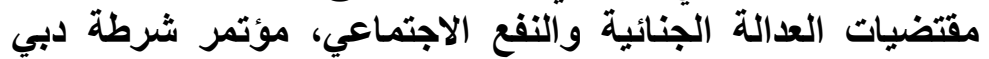

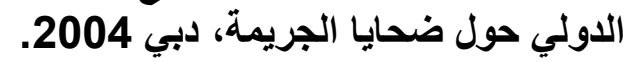

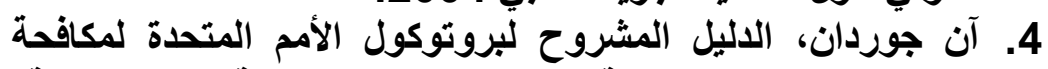

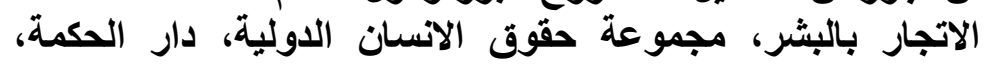

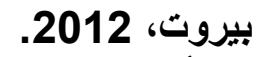

5. د. أحمد عبد اللطيف الفقي، الحماية الجنائية لحقوق ضحايا

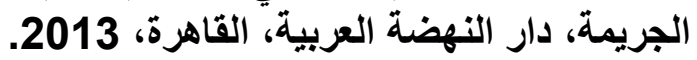

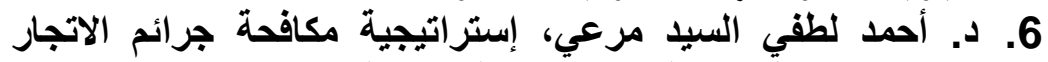

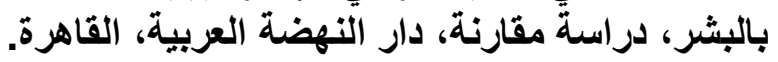

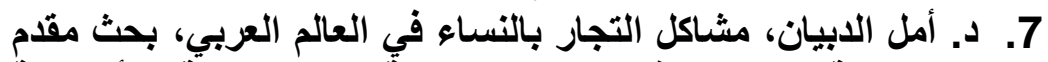

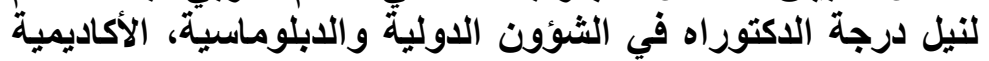
السورية الدولية، 2010. 8. د. جعفر محمد خضير، الحق فئ في محاكمة عادلة، رسالة دكتوراة، جامعة بغداد، 1992 ( 199 9. د. حاتم حسن بكار، سلطة سلة القاضي الجنائي، منشأة المعارف،

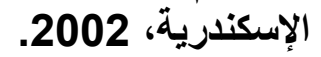

د. حسن صادق المرصفاوي، الدعوى المدنية أمام المحاكم

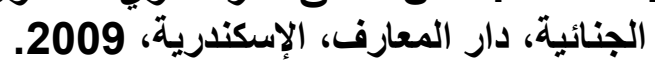

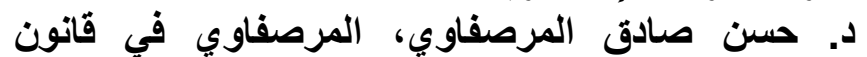

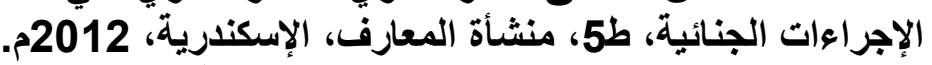
12.

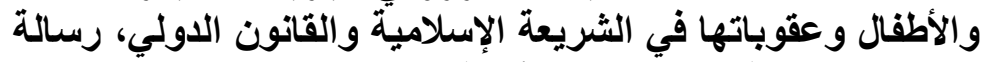

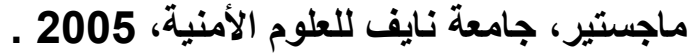
د. خديم نبيل، استيفاء حقوم الإنيف، الضحايا في القانون الجنائي .13

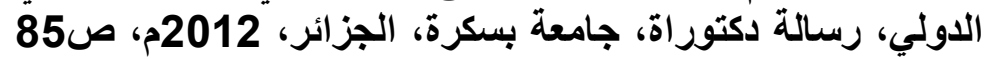

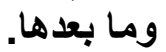

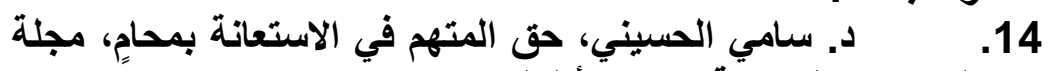

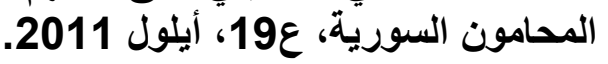




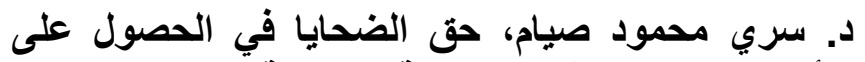

التعويض، أعمال المؤتمر الثالث للجمعية المصرية للقانون الجنائي،

1990

16. 199. سوزي عدلي ناثد، الاتجار في البشر بين الاقتصاد

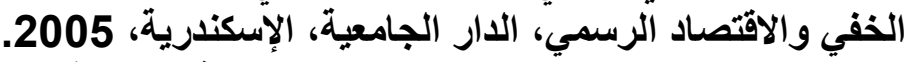

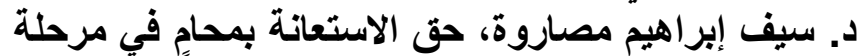

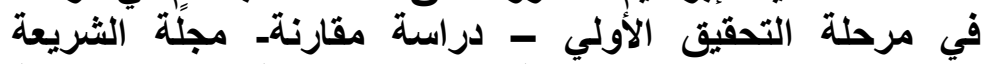

والقانون، كليه القانون، جأمعة الإمارات العربية المتحدة، المالية السنة

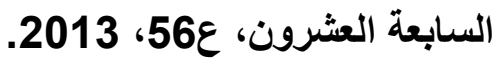

د. صلاح عبد المتعال، الدراسة العلمية للمجني عليه، دار

المعارف، القاهرة،

عادل عبد الجواد محمد الكردوسي، الجمعيات غيري

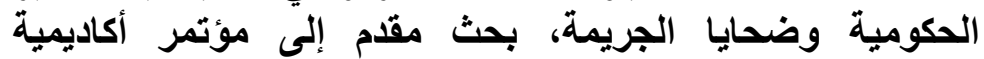

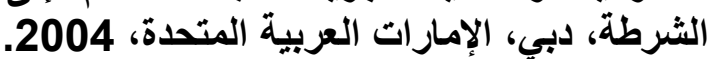

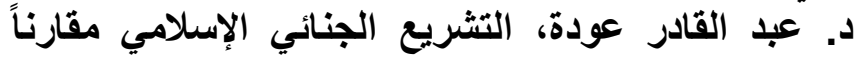

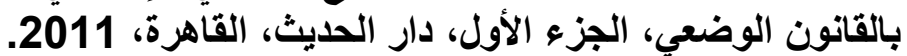

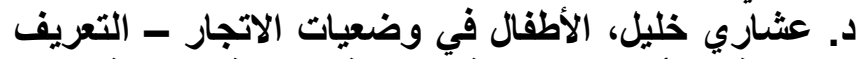

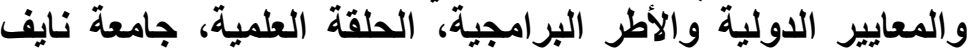

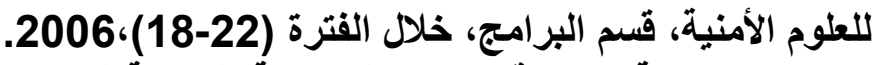

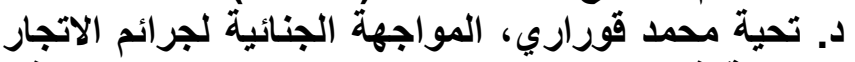

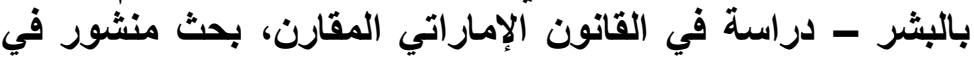

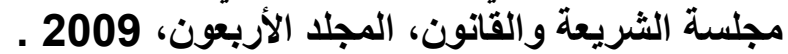

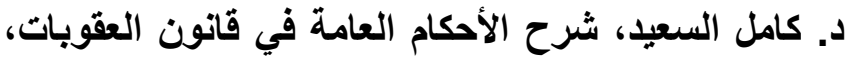

دراسة مقارنة، الطبعة الثالثة، دار الثقافة للنشر والتوزيع، فانون العان الثان

.2011

د. محمد الأمين البشري، علم ضحايا الجريمة وتطبيقاته

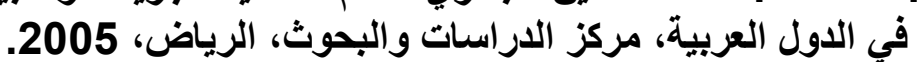

د. محمد سعيد نمور، أصول الإجراءات البرات الجزائية، دار

الثقافة، عمان، 2014 التمد

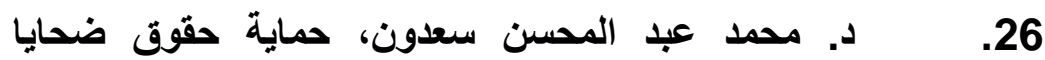

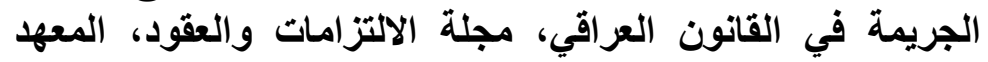

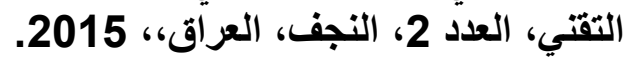

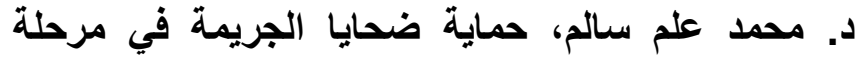

التحقيق الابتائي، مجلة القانون، جامعة بابل، عائة 1، 2008. 


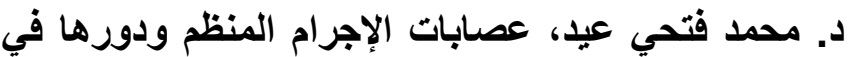

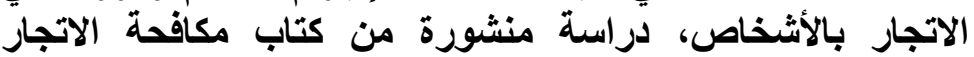
بالأشخاص والأعضاء البثرية، صادر عن جامعة نايف للإنة للعلوم الأمنية، الرياض، و داصن 2004.

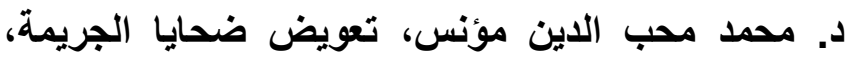

جامعة نايف العربية للعلوم الأمنية، الرياض، دوند 2005.

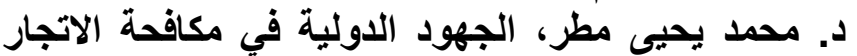

بالبشر، الجزء الأول، منشورات جامعة نايف للعلوم الأمنية، الرياض، البيز، الجزء 2010.

د. محمود شريف بسيوني، الجريمة المنظمة عبر الوطنية

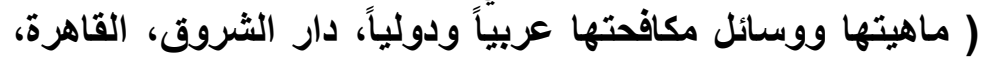
ط3، ماهن 2009.

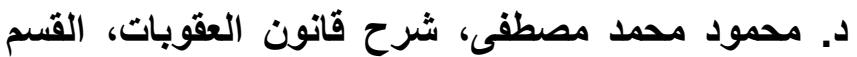

العام، الطبعة الخامسة عشر، مطبعة دار النهضة العربية، القاهرة،

د. مسعود محمد مرسي، شكوى المجني عليه، رسالة

دكتوراة، أكاديمية الثرطة، القاهرة،

د. مصطفى طاهر، إطلالة على القانون الآند الاتحادي لمكافحة

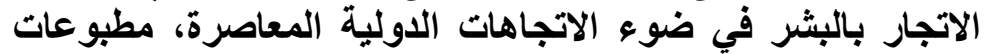
مركز البحوث والدراسات الأمنية، القيادة العامة لثرطة أبو ظبية الثبات

د. مصطقى مصباح دبارة، وضع ضحايا الإجرام في النظام

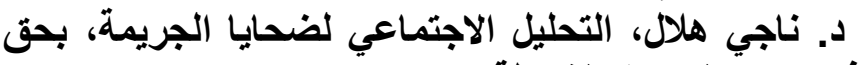

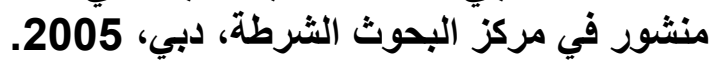

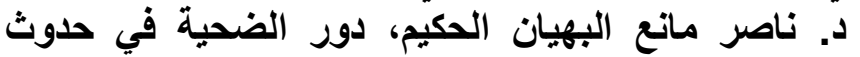

الجريمة، رسالة دكتوراة، جامعة نايف للعلوم الأمنية، ألرياض، دئ دان

2007م.

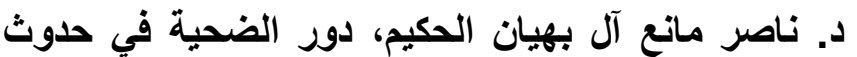

الجريمة، رسالة ماجستير جامعة نايف للعلوم الأمنية، ألرياض، داض

2007

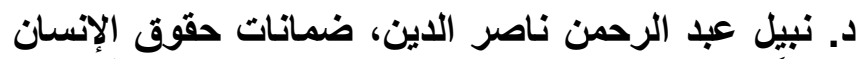

وحمايتها وفقاً للقانون الدولي، دار الفكر العربي، الإسكندرية، ط2 الإن،

د. نصر الدين بوسماحة، حقوق ضحايا الجرائم الدولية

على ضوء أحكام القانون الدولي، دارئ، دار الفكر العربي، الإسكندرية، الجرائ،

مصر، الطبعة الأولى، 2007. 
د. نور الدين هنداوي، المجني عليه بين القانون الجنائي

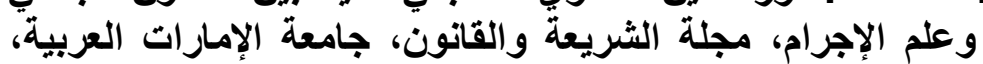
كلية الشريعة والقانون، العدد الثاني، 1988.

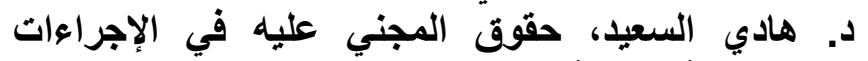
الجنائية، دار النهضة العربية، القاهرة،

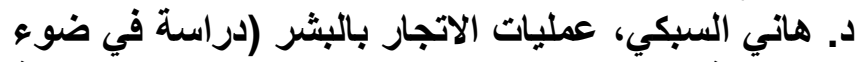
.43

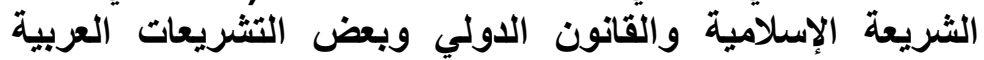

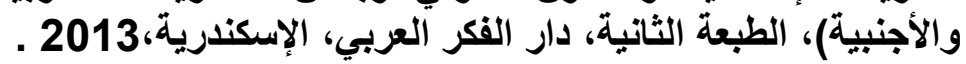

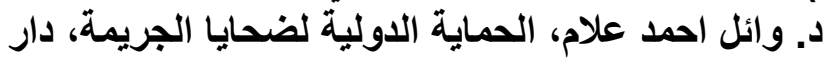

النهضة العربية، القاهرة، 2004 التمل 200 
1. Gérard lopez: Victimologie, Dalloz, paris, 1997.

2. Francoise ALT-MAES: "Le concept de La victim en droit civil eten droit pénal" RSC, no=1994.

3. Sandra walkat: criminology the basics, willan.2007.

4. Bonnie.S.fisher. Steven. P. lab; Encyclopedia victimology and crime preventation. Volume1 sage publications, california, 2010.

5. Andrew Karmen: Crime Victime; An Introduction to victimology, eight Edition, Belomont, USA, 2012.

6. Von Hentig. Hans - Remarks on the interaction between perpetrator and victims - Journal of the American institute of criminal law and Criminology Vol. 31. 1997..

7. Mende Isohn. B.A, New Branch of Biopsychologyical seience "La victimology : Revue international de Criminologie et depolice Technique No.2. 1999.

8. Naoum salamé, Génétique moléculaire et spécificités humaine, Jean- claude Hervé, 2013.

9. Naoum salame, Génétique moléculaire et spécificités humaine, Jean-claude Hervé, 2013.

10. Kelly E.Hyland protecting Human Victims of Trafficking, An American Framework, 2009.

11. Akers (T) \& Lanier,(m), Epidemiological Criminology, Am j public health March, 2009.

12. Van den Hoven, (A) \& maree, (A): Victimization risk factors, repeat Victimization and victim profiling. In Davis, L \& Snyman, R.victimology in south A frica. Van shaik Publishers 2005.

13. Anne D'HAUTVILLE: les droits des victmes, Rev.Sc.crim Janv, mars 2001.

14. William TALLACK; reparation to the injured and the rights of the victmes of crime to compensation, London, 2008.

ثالثاً: المراجع الاكترونية

.www.unhehr.ch/htm/menu3/b/f2sc.htm www.unhehr.ch/htm/menu3/b/f2sc.htm 